UNIVERSIDADE DE SÃO PAULO

ESCOLA DE ENGENHARIA DE SÃO CARLOS

THIAGO FRANCISCO DE MORAES

ESTUDO DE TÉCNICAS CONCEITUAIS DE RECAPEAMENTO DE QUADRIL DE CÃES 
THIAGO FRANCISCO DE MORAES

\title{
ESTUDO DE TÉCNICAS CONCEITUAIS DE RECAPEAMENTO DE QUADRIL DE CÃES
}

\author{
Dissertação apresentada à Escola de \\ Engenharia de São Carlos da Universidade de \\ São Paulo, para obtenção do título de Mestre em \\ Engenharia Mecânica.
}

Área de concentração: Projeto Mecânico

Orientador: Prof. Dr. Benedito de Moraes Purquerio. 


\section{FOLHA DE JULGAMENTO}

Candidato: Bacharel THIAGO FRANCISCO DE MORAES

Título da dissertação: "Estudo de técnicas conceituais de recapeamento de quadril de cães".

Data da defesa: 16/12/2011

Comissão Julgadora:

Prof. Titular Benedito de Moraes Purquerio (Orientador)

(Escola de Engenharia de São Carlos/EESC)

Prof. Associado Carlos Alberto Fortulan

(Escola de Engenharia de São Carlos/EESC)

Prof. Dr. Francisco Cláudio Dantas Mota

(Universidade Federal de Uberlândia/UFU)

Coordenador do Programa de Pós-Graduação em Engenheira Mecânica:

Prof. Associado Marcelo Areias Trindade

Presidente da Comissão de Pós-Graduação:

Prof. Associado Paulo Cesar Lima Segantine
Resultado:
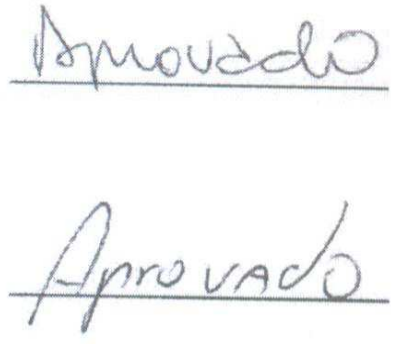

Anrovado 
Dedico esta conquista com grande orgulho, em especial a três pessoas que em minha vida foram e serão sempre muito importantes. In memorian a minha mãe Maria Ap. Jacintho de Moraes, ao meu pai José Francisco de Moraes e a minha esposa, Adriana Pereira de Moraes, pois sem elas acho que não teria alcançado a grande vitória de me tornar Médico Veterinário e hoje, poder realizar este trabalho. 


\section{AGRADECIMENTOS}

Os meus sinceros agradecimentos

A Deus primeiramente por fazer maravilhas em nossas vidas todos os dias e principalmente por dar-nos saúde para que possamos seguir adiante enfrentando os desafios que a vida nos impõe.

Ao professor titular Benedito de Moraes Purquerio Pela orientação durante todo mestrado, pela liberdade dentro do laboratório e pelos conselhos que foram de grande valia.

Ao professor Carlos Alberto Fortulan pela paciência e ajuda oferecida durante todo este trabalho.

Ao professor João Manuel Domingos de Almeida Rollo pelo apoio e incentivo durante as disciplinas oferecidas na pós-graduação.

A todos os professores que fizeram parte de minha vida no período de graduação na Universidade Camilo Castelo Branco, pois sempre me incentivaram a estudar para tornarme um médico veterinário competente.

Ao professor Francisco Claudio Dantas Mota pelo incentivo e pela minha formação.

À minha mãe (In memorian) pela força espiritual dada, pois nas horas mais difíceis de minha vida, os problemas cessavam-se quando nela pensava a ela meu eterno agradecimento.

Ao meu pai, José Francisco de Moraes por ser meu melhor amigo e por me ensinar a ser um homem de caráter, meu eterno agradecimento.

À minha esposa Adriana Pereira de Moraes simplesmente pelo fato de fazer parte de minha vida, pela paciência e apoio dado a todo o momento, sem ela acho que não teria forças para enfrentar as dificuldades que passei e poder concluir este grande trabalho.

Aos meus irmãos André e Fernando pela força dada nos momentos em que precisei, agradeço a Deus por serem meus irmãos.

A todos os meus familiares sem exceção, pois sempre soube que poderia contar com eles em qualquer momento de minha vida.

Aos colegas de laboratório Luiz Adalberto Penazzi, Luiza Alves de Souza, Karen Laurenti, Claudia, Camila e Renan pelo companheirismo durante toda etapa deste trabalho.

Aos companheiros de Café durante as manhãs, meu paizão Xina e os colegas Serginho, Diego e Leandro.

Ao José Carlos Risardi, técnico do LAMAFE - EESC - USP pela prestividade em manufaturar o ferramental cirúrgico desenvolvido em meu trabalho. 
A todas as pessoas responsáveis pela limpeza do laboratório, pois sem elas não teria o conforto e comodidade, muito obrigado.

Aos funcionários da biblioteca do campus, mas em especial a Heleninha pela ajuda dada sem medir esforços, pelos conselhos, pelo companheirismo e pelo incentivo dado, obrigado por tudo.

À secretária Cristina do laboratório de dinâmica por ter acompanhado meu crescimento, pelas ajudas durante o mestrado e pela confiança profissional, muito obrigado.

A Deus sempre. 
"Chegará o dia em que os homens conhecerão a alma dos animais, e nesse dia um crime contra um animal será considerado um crime contra a própria humanidade."

Leonardo Da Vincí 


\section{RESUMO}

MORAES, T. F. (2011). Estudo de técnicas conceituais de recapeamento de quadril de cães. 152 f. Dissertação (Mestrado) - Escola de Engenharia de São Carlos, Universidade de São Paulo, São Carlos, 2011.

É estudada, conceitualmente a técnica de recapeamento de quadril de cães como modelo cirúrgico. A artroplastia do quadril foi desenvolvida com a finalidade de restabelecer a mobilidade articular e também no alívio da dor de pacientes humanos. Em animais, principalmente os cães, a artroplastia total, é um procedimento cirúrgico muito utilizado na articulação coxofemoral para a correção de patologias de quadril, sejam elas degenerativas traumáticas ou inflamatórias além de aliviar a dor. A artroplastia de recapeamento de quadril em humanos tem se mostrado uma técnica muito eficiente por estar próxima da anatomia natural do quadril e tem sido aplicada em pacientes jovens e ativos. A vantagem de se realizar a técnica de recapeamento é que nesta, há uma ressecção mínima da cabeça femoral e que promove uma melhora em relação à estabilidade da articulação, entretanto essa técnica ainda não é aplicada em animais. O presente trabalho tem por objetivo estudar a técnica de recapeamento de quadril de cães de forma análoga as técnicas aplicadas em humanos e também, propor um projeto de ferramental cirúrgico específico em conjunto com o protocolo cirúrgico. A técnica conceitual de artroplastia de recapeamento de quadril de cães foi desenvolvida a partir de um fêmur canino onde foram desenvolvidos os conceitos da técnica cirúrgica e o protótipo do ferramental cirúrgico necessário para o desenvolvimento desta técnica. Inicialmente foram feitas aquisições das imagens dos objetos do trabalho (fêmur canino, ferramental cirúrgico e prótese cirúrgica) que foram convertidas em arquivos CAD; a partir destes foram gerados cópias em gesso através do processo de impressão 3D do ferramental cirúrgico desde o guia de furação até a fresa de chanframento e também da prótese cirúrgica de recapeamento. A fabricação do ferramental cirúrgico obtido pelo processo de impressão 3D possibilitou uma análise visual dos protótipos que serviram de modelos para a fabricação do ferramental cirúrgico definitivo, sendo este, confeccionado em aço. Isso permitiu sua validação em bancada de laboratório através de testes realizados em modelos de ossos de cães em resina. Conclui-se que a técnica de recapeamento de quadril de cães validada em bancada de laboratório poderá ser realizada em conjunto com o ferramental cirúrgico proposto para em um futuro muito próximo ser usado em articulações de cães portadores de displasia coxofemoral devido a sua funcionalidade e à demanda de casos clínicos para este procedimento. A técnica cirúrgica de recapeamento estudada poderá ser oferecida a população a um custo acessível por ser inovadora e promissora no contexto da ortopedia veterinária.

Palavras-chaves: Displasia coxofemoral canina, Recapeamento de quadril de cães, Protocolos cirúrgicos, Ferramental cirúrgico. 


\begin{abstract}
MORAES, T. F. (2011). STUDY OF CONCEPTUAL TECHNIQUES FOR DOGS HIP RESURFACING. 152 f. M.Sc Dissertation (Master) - School of Engineering of São Carlos, University of São Paulo, São Carlos, 2011.

The study conceptually describes a surgical model for dog hip resurfacing technique. Hip arthroplasty was developed to restore joint mobility and relieve of human patients pain. In animals, especially dogs, total arthroplasty is a surgical procedure commonly used to correct traumatic, degenerative and inflammatory hip diseases and alleviate pain. The resurfacing hip arthroplasty in humans, applied in young and active patients, has shown to be an efficient technique. The advantage of using this technique is that there will be a minimal resection of the femoral head, improving the stability of the joint; however it has not been applied to animals yet. The present dissertation reports on the study of hip resurfacing technique for dogs in a similar way it is applied in humans. It also proposes a specific surgical tooling design in conjunction with the surgical protocol. The technical concept of hip resurfacing arthroplasty for dogs was developed from a canine femur from which the concepts of the surgical technique and the prototypes of the necessary surgical tools were developed. Initially, images of the objects used in the work (canine femur, surgical tools and surgical prosthesis) were acquired. They were then converted into CAD files, which generated plaster copies of surgical tools, from the hole guide to the to cutter and chamfer, and also surgical resurfacing prosthesis through the $3 \mathrm{D}$ printing process. The manufacture of the surgical tools models obtained by 3D printing process allowed a visual analysis of the prototypes that served as references for the definitive surgical tool made in steel. Such tools were validated by means of laboratory bench tests using resin models of dogs bones. It was possible to conclude that the technique of hip resurfacing in dogs can be employed in conjunction with the proposed surgical tools in the joints of dogs with hip dysplasia in a very near future. Due to its full functionality and large demand of clinical cases for this procedure, the technique may be offered to the population at an affordable cost. It is also an innovative and promising technique in the context of veterinary orthopedics.
\end{abstract}

Keywords: Canine hip dysplasia, dog hip resurfacing, surgical protocols, surgical tool. 


\section{LISTA DE FIGURAS}

Figura 2.1- Articulação do quadril do cão ................................................... 20

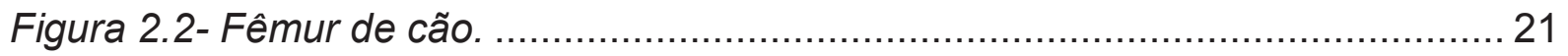

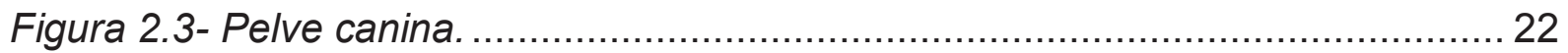

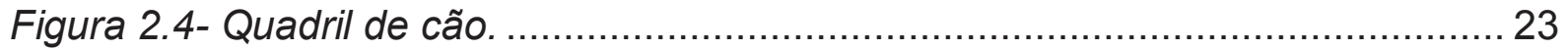

Figura 2.5- Desenho esquemático do fêmur de cão, ilustrando o ângulo de inclinação

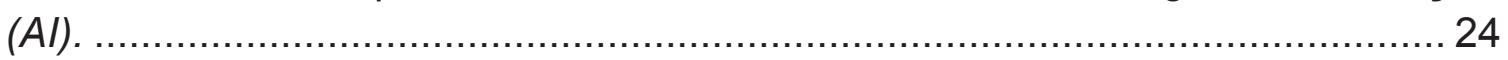

Figura 2.6- Desenho esquemático do fêmur de cão, ilustrando o ângulo de

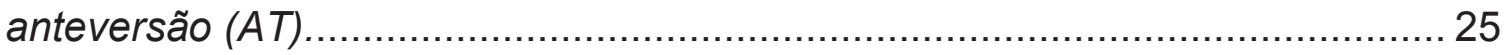

Figura 2.7- Desenho esquemático da articulação coxofemoral de cão, ilustrando as forças que agem sobre a articulação do quadril no plano transverso ................ 26

Figura 2.8- Acesso dorso-caudal à articulação coxofemoral, incisão da pele em forma elíptica tendo como referencia o trocânter maior ................................ 28

Figura 2.9- Incisão da fáscia lata para visualização da inserção do músculo tensor da fáscia lata com o músculo glúteo médio...................................................... 28

Figura 2.10- Afastamento caudal do nervo ciático ............................................. 29

Figura 2.11- Incisão dos músculos gêmeos e cápsula articular dorsal, para exposição da cabeça femoral ................................................................................... 29

Figura 2.12- Rotação do membro pélvico no sentido caudal para exposição da cabeça e colo femoral ........................................................................ 29

Figura 2.13- Excisão e exposição da cabeça femoral ......................................... 29

Figura 2.14- Modelo em resina da aplicação de prótese total de quadril de cães .... 31

Figura 2.15- Radiografia da articulação de um cão 90 dias após a colocação da prótese total .................................................................................. 31

Figura 2.16- Radiografia mostrando a soltura do componente protético três dias após sua colocação

Figura 2.17- Prótese total de quadril cimentada ................................................. 33

Figura 2.18- Prótese total de quadril não cimentada .......................................... 33 
Figura 2.19- Instrumental cirúrgico utilizado para realização de artroplastia total de quadril em cães

Figura 2.20- Serra pneumática autoclavável utilizada para osteotomia de cabeça e colo

Figura 2.21- Fio serra utilizado para osteotomia de cabeça e colo femoral

Figura 2.22- Furadeira de baixa rotação utilizada na ortopedia veterinária

Figura 2.23- Cimento ósseo acrílico utilizado para fixação de próteses metálicas de quadril .....

Figura 3.1- Componentes de uma prótese de quadril.

Figura 3.2- Prótese de quadril dos irmãos JUDET

Figura 3.3- Prótese total de quadril não cimentada ...........................................48

Figura 3.4 Componentes de artroplastia total de quadril. .....................................49

Figura 3.5 Prótese de projeto modular .................................................... 50

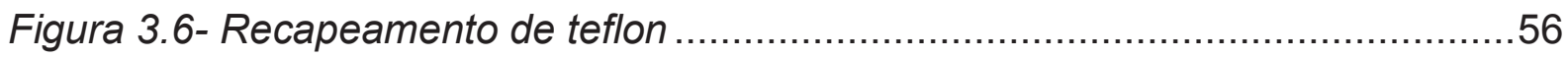

Figura 3.7- Componente femoral para hemiresurfacing de artroplastia femoral........57

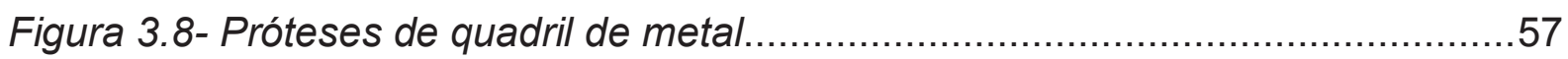

Figura 3.9- Recapeamento de quadril cimentado..........................................59

Figura 3.10- Sistema de recapeamento cimentado de metal-polietileno ...................59

Figura 3.11- Prótese para artroplastia de recapeamento cimentada......................60

Figura 3.12- Sistema de substituição de superfície porosa .................................60

Figura 3.13- Principais implantes metálicos de recapeamento existentes no mercado

Figura 3.14- Molde de artroplastia em forma de sino. ......................................62

Figura 3.15- Artroplastia total de quadril de aço inoxidável ...................................64

Figura 3.16- A seção transversal cônica e flanges concebidos para produzir

compressão no manto do cimento introduzido por CHARNLEY em 1975. A

Figura à direita mostra componente acetabular revestido com hidroxiapatita ....67

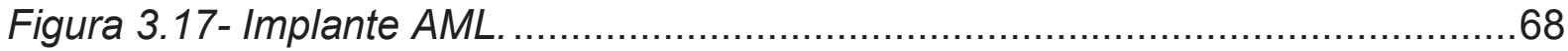

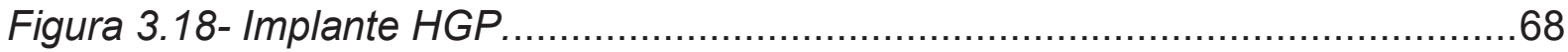


Figura 3.19- Os fragmentos de desgaste são um dos principais problemas modernos associados à substituição de quadril. As partículas de polietileno da linha do acetábulo são atacadas pelo sistema imune do paciente, destruindo o osso ao redor do implante, com eventual soltura. .................................................... 70

Figura 3.20- Verificação do posicionamento do pino ...................................... 72

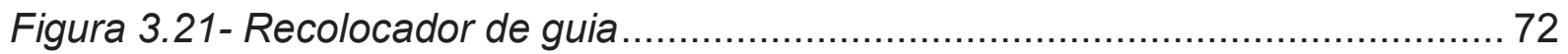

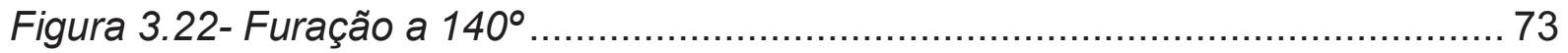

Figura 3.23- Preparação femoral com auxílio de uma toalha ................................ 73

Figura 3.24- Remoção dos destroços de modo que o alinhamento do guia seja posicionado reto no topo da guia de corte e rodado até ajustar........................ 74

Figura 3.25- Chanframento da cabeça femoral ........................................... 74

Figura 3.26- Colocação de um receptor para coleta de fragmentos ósseos.............75

Figura 3.27- Verificação do formato da cabeça femoral ..................................... 75

Figura 3.28- Superficíe femoral limpa e seca ............................................ 76

Figura 3.29- O componente femoral recebe o cimento acrílico ............................. 76

Figura 3.30- Medição da cabeça do fêmur ...................................................... 77

Figura 3.31- Preparação para a pré-furação............................................... 78

Figura 3.32- Furação com broca canulada ................................................ 79

Figura 3.33- Refilamento da cabeça femoral ............................................... 79

Figura 3.34- Plainamento da cabeça femoral ............................................ 80

Figura 3.35- Preparação da superfície plana ............................................. 80

Figura 3.36- Chanframento da cabeça do fêmur .......................................... 81

Figura 3.37- Medição e checagem do formato da cabeça do fêmur usinada ........... 81

Figura 3.38- Assentamento do recapeamento............................................ 82

Figura 3.39- Palpação e marcação da linha de incisão. ..................................... 83

Figura 3.40- O retrator permite retração e exposição profunda do tecido mole ........ 83

Figura 3.41- $A$ exposição adequada permite o escareamento do acetábulo ............ 84

Figura 3.42- Posicionamento correto de um pino guia de 3,2 $\mathrm{mm}$ com uso de um goniômetro 
Figura 3.43- Posicionamento do pino no centro do colo femoral.

Figura 3.44- Antes de iniciar o escareamento cilíndrico da cabeça femoral, o pino femoral é medido com um goniômetro para confirmar o ângulo entre 135 a $140^{\circ}$

Figura 3.45- Uso de guia cilíndrico para escareamento da cabeça femoral..... .87

Figura 3.46- O componente femoral cimentado no local.

Figura 3.47- Após o cimento ser curado, o quadril é reduzido e os componentes femoral e acetabular são testados

Figura 4.1- Guia de alinhamento de furação da cabeça do fêmur... 102

Figura 4.2- Fresa serra copo para refilamento cilíndrico da cabeça femoral...... 103

Figura 4.3- Guia para plainamento da cabeça femoral 104

Figura 4.4- Fresa de topo para plainamento cabeça do fêmur. 104

Figura 4.5- Fresa para chanframento da cabeça femoral. 105

Figura 5.1- Fêmur de cão e réplica em resina.

Figura 5.2- Furação e guia de furação da cabeça do fêmur de cão

Figura 5.3- Refilamento cilíndrico da cabeça femoral de cão com fresa (serra) Copo

Figura 5.4- Fresa reta para o faceamento da cabeça femoral (cilíndrica) de cão ...113

Figura 5.5- Chanframento das bordas da superfície cilíndrica com fresa de topo biselada

Figura 5.6- Perfil final da cabeça do fêmur de cão para a colocação da prótese de recapeamento.

Figura 5.7- Prótese de recapeamento de quadril de cão (01-03). Simulação do assentamento da prótese (04).

Figura 5.8- Etapa final do recapeamento de quadril de cão. Comparação com o modelo original (natural)

Figura 5.9- Finalização da cirurgia conceitual de bancada de recapeamento de quadril de cão 


\section{LISTA DE TABELAS}

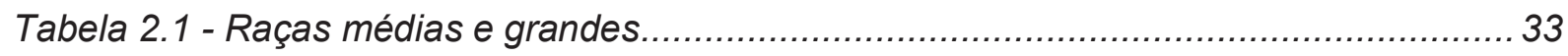

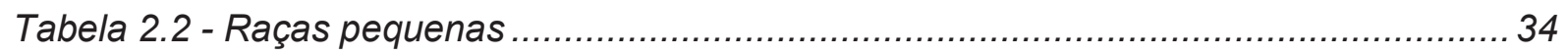

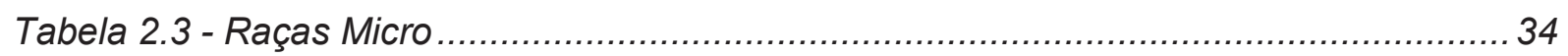

Tabela 3.1 - Tipos de cirurgias de revisão encontradas na literatura................................. 42

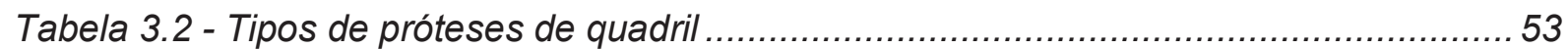

Tabela 3.3 - Exemplos de aplicações, vantagens e desvantagens dos biomateriais utilizados

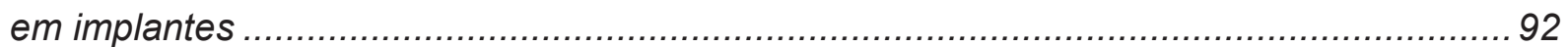




\section{LISTA DE SIGLAS}

\begin{tabular}{|c|c|}
\hline Al & Alumina \\
\hline$D C F$ & Displasia coxofemoral \\
\hline PMMA & Polimetilmetacrilato \\
\hline At & Ângulo de anteversão \\
\hline $\mathrm{Fa}$ & Força dos músculos abdutores \\
\hline Fo & Peso corporal \\
\hline$F k$ & Força de reação do solo \\
\hline$F h$ & Força total sobre a articulação coxofemoral \\
\hline$\Theta n$ & Ângulo da força total de quadril \\
\hline$\Theta h$ & Aumento do ângulo de inclinação \\
\hline $\mathrm{Fa}$ & Aumento na força sobre a cabeça do fêmur \\
\hline$M m$ & Milímetros \\
\hline 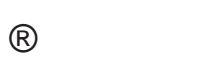 & Marca registrado \\
\hline $\mathrm{NIH}$ & National Institutes of Health \\
\hline sus & Sistema Único de Saúde \\
\hline ASTM & American Society for Testing Materials \\
\hline ISO & Internetional Organization for Standartization \\
\hline EUA & Estados Unidos da América \\
\hline$F D A$ & Food and Drug Administration \\
\hline NBR & Norma brasileira \\
\hline UHWMPE & Polietileno de ultra - alto peso molecular \\
\hline$x$ & Versus \\
\hline ANVISA & Agência Nacional de Vigilância Sanitária \\
\hline$H D P$ & Polietileno de alta densidade \\
\hline$A I S I$ & American Iron and Stell Institute \\
\hline EESC & Escola de Engenharia de São Carlos \\
\hline
\end{tabular}





\section{SUMÁRIO}

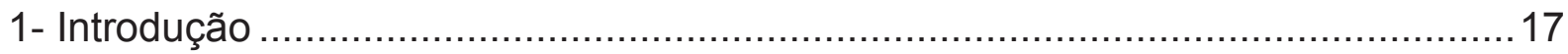

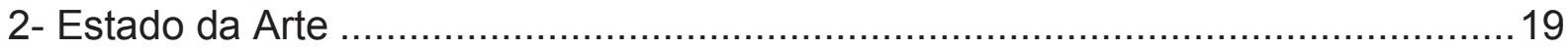

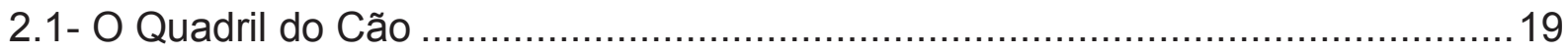

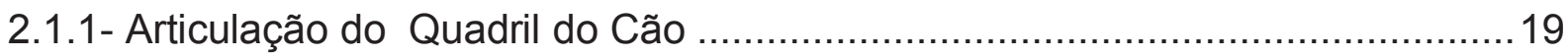

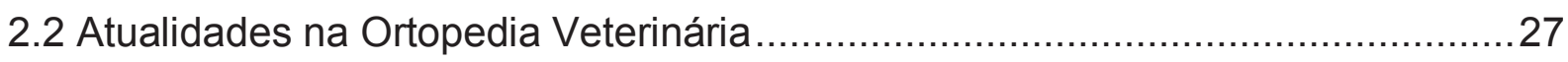

2.3 Patologias do Quadril do Cão x Tratamento Cirúrgico ………….....................27

2.4 Próteses cirúrgicas utilizadas para artroplastia de quadril de cães .................... 32

2.5 Ferramental cirúrgico e Materiais utilizados para artroplastia total de quadril em cães 35

2.6 Procedimentos realizados na artroplastia total de quadril de cães.....................37

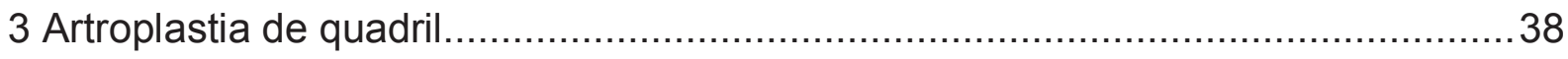

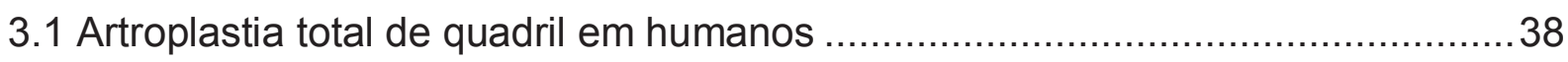

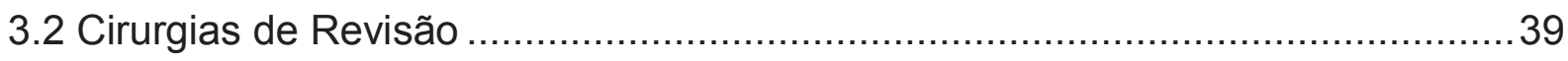

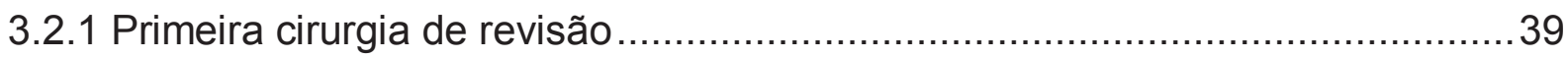

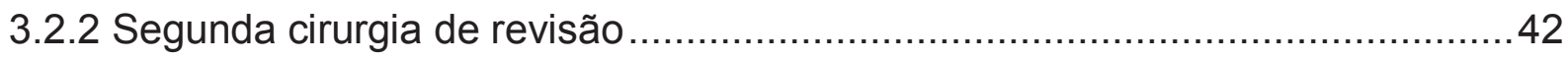

3.2.3 Próteses cirúrgicas de quadril utilizadas na ortopedia humana .........................45

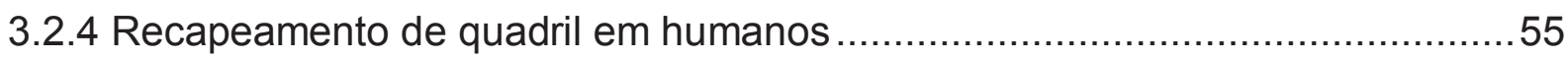

3.2.5 Modelos de Implantes de Recapeamento ..................................................

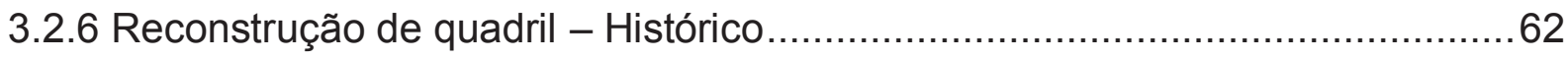

3.2.7 Instrumental cirúrgico para recapeamento ……...........................................

3.2.8 Ferramental cirúrgico para artroplastia total de quadril ................................8

3.2.9 Tipos de materiais utilizados em próteses de quadril ....................................89

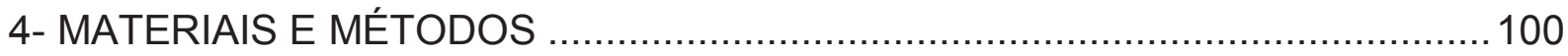

4.1- Técnica Conceitual para recapeamento de Quadril de Cães .......................... 101

4.1.1 Guia de alinhamento de furação .........................................................101

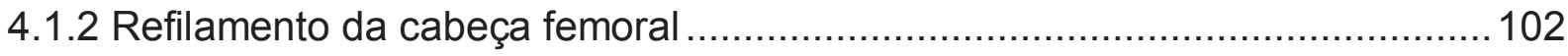


4.1.3 Guia para plainamento da cabeça femoral 103

4.1.4 Plainamento da cabeça do fêmur ................................................ 104

4.1.5 Chanframento da cabeça do fêmur................................................ 105

4.1.6 Verificação do assentamento .............................................................. 106

4.2 Assentamento da Prótese Cirúrgica de Recapeamento Femoral .................... 106

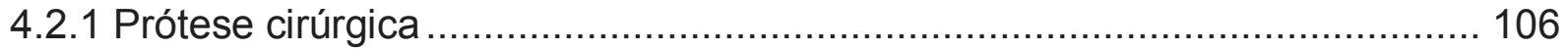

4.2.2 Fixação biológica da prótese cirúrgica .............................................. 107

4.2.3 Verificação final do assentamento da prótese cirúrgica ........................... 108

4.2.4 Estabilização da prótese cirúrgica ................................................. 108

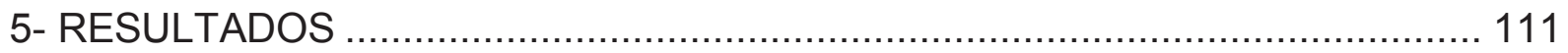

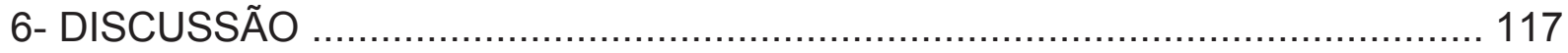

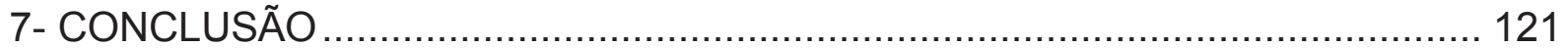

8-SUGESTÕES PARA TRABALHOS FUTUROS ......................................... 122

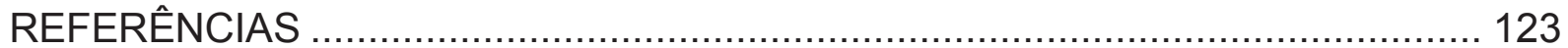

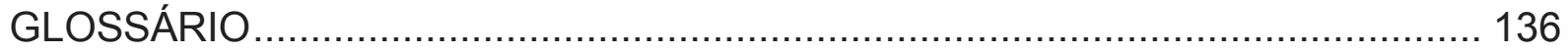

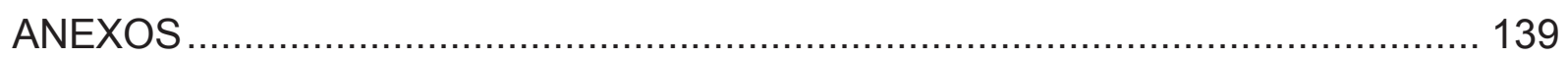

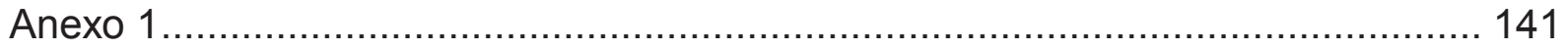

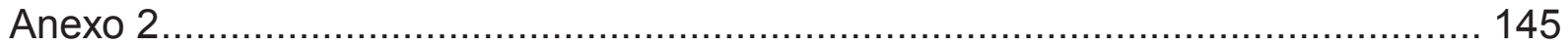




\section{1- INTRODUÇÃO}

A artroplastia total da articulação coxofemoral é a técnica cirúrgica mais indicada para o tratamento da displasia coxofemoral canina grave (IWATA et al., 2008). Associada a esta realidade, a displasia coxofemoral é considerada a principal causa de claudicação do membro posterior, com conseqüente dor e redução na qualidade de vida dos cães, especialmente os de porte grande e gigante (PIERMATTEl et al., 2006; SHULZ, 2008). Diversos tratamentos são descritos na literatura para a correção da referida patologia, entretanto, o procedimento protético é considerado o único capaz de restaurar a função articular, nos casos de lesões degenerativas ou osteoartrítica grave (LISKA e POTEET, 2003; MINTO et al., 2006).

A artroplastia de quadril em humanos foi desenvolvida com a finalidade de restabelecer a mobilidade articular e também para proporcionar alívio da dor do paciente (KUSHIYAMA; ISHIDA; TRIGUEIRO, 2001). A artroplastia primária do quadril é um procedimento utilizado para a correção de patologias degenerativas, traumáticas ou inflamatórias e ainda, este procedimento pode ser total, parcial ou de recapeamento (Resurfacing). $\mathrm{Na}$ artroplastia total de quadril podem ser substituídos tanto o componente femoral como também a parte que envolve o acetábulo, pois ambos podem estar alterados; já no procedimento de artroplastia parcial de quadril somente o componente femoral é substituído preservando apenas a sua parte acetabular desde que esta esteja intacta. Os implantes utilizados na artroplastia de quadril podem ser classificados em cimentados, não cimentados e também do tipo híbrido (SILVESTRE FILHO, 2006).

Em humanos, com o aumento das artroplastias de quadril, em conjunto com uma maior expectativa de vida da população, resultou em um aumento no número de cirurgias de revisão (TRUETA, 1975; RUDELLI et al., 1992). Isto ocorreu devido aos avanços tecnológicos que ganharam aplicação prática e tornou mais acessível à população esse tipo de cirurgia (ETCHEBEHERE, 1998). Por outro lado, Wrege (2000) destaca o envelhecimento (idade) como um dos fatores que contribuem para o aumento de cirurgias de reconstrução óssea. A artroplastia de recapeamento (do inglês, resurfacing) de quadril em humanos tem se mostrado uma técnica muito eficiente por estar próximo da anatomia natural do quadril e esta técnica tem se mostrado eficiente em pacientes jovens e ativos. Para a realização desta técnica é necessária a remoção de algumas lesões da cabeça femoral e do acetábulo. Ambos os componentes (femoral e acetabular) devem ser cuidadosamente medidos para assegurar que os implantes se encaixem perfeitamente (ADAMS; QUIGLEY, 2005). A vantagem de se realizar a técnica de recapeamento é que nesta haverá uma ressecção mínima da cabeça femoral e também haverá uma melhora em 
relação à estabilidade da articulação (PRITCHETT; TOWNLEY, 2002; LOUGHEAD et al., 2005).

Em humanos existem formas diferentes de tratamento cirúrgico descritos na literatura nacional e internacional como, por exemplo, artroplastia total com material metálico ou material metálico e cerâmico, e outra técnica que talvez seja mais promissora por estar mais próximo da anatomia que seria a artroplastia de recapeamento de quadril (resurfacing).

Em contraste, na medicina veterinária é inexistente a descrição da técnica de recapeamento (resurfacing) de quadril em cães e a técnica mais indicada na atualidade é a artroplastia total com implantes metálicos, sendo este de alto custo.

Após a realização da técnica de artroplastia total coxofemoral tanto em cães como em humanos, algumas complicações poderão ocorrer durante o pós-operatório tais como afrouxamento asséptico dos componentes (femoral e acetabular), infecções e até mesmo fraturas femorais.

Algumas patologias como displasia coxofemoral, necrose asséptica da cabeça do fêmur, artrite e artrose levam os animais a perda da função do membro afetado sendo necessária a intervenção do médico veterinário para a colocação de um implante em uma ou até mesmo nas duas articulações coxofemorais.

$\mathrm{Na}$ maioria das clínicas veterinárias do Brasil, cães de raças pequenas, média e grandes necessitam de implantes para a correção de patologias articulares de quadril; mas, na prática, não é bem o que acontece devido à falta de cirurgiões tecnicamente especializados para a realização desta técnica e do alto custo da cirurgia. Em cães de raças pequenas, uma das opções de tratamento usualmente utilizada para correções de patologias da cabeça femoral, principalmente a necrose asséptica da cabeça do fêmur, é a colocefalectomia, ou seja, ressecção da cabeça e colo femoral, que por sua vez torna-se mais economicamente viável para o proprietário e ameniza consideravelmente a dor do animal, porém esta prática não estabiliza a articulação coxofemoral, e para cães de raças grandes, é indicado o uso de componentes protéticos.

Durante o desenvolvimento deste trabalho, não foram encontrados estudos da aplicação da técnica de recapeamento (resurfacing) de quadril de cães na literatura nacional e internacional e de um ferramental cirúrgico especifico; tal fato, associado à indicação do procedimento para uma afecção cada vez mais freqüente na clínica de pequenos animais, o alto custo da prótese (nacional e importada) e a não existência da técnica no Brasil, estimularam o desenvolvimento desta pesquisa que tem por objetivo, o desenvolvimento da técnica conceitual de artroplastia de recapeamento de quadril de cães juntamente com uma proposta de ferramental cirúrgico específico para que em um futuro próximo, possa ser aplicado em cães melhorando sua qualidade de vida e posteriormente utilizado em humanos. 


\section{2- ESTADO DA ARTE}

\section{1- O Quadril do Cão}

Neste capitulo é discutida a anatomia da articulação coxofemoral canina (quadril) para um melhor entendimento sobre o exato local (alvo de estudo) nos cães (fêmur e acetábulo), foco em que as patologias de quadril mais afetam os cães de pequeno médio e grande porte, fazendo também uma revisão sobre estas patologias ortopédicas de quadril dos animais e suas respectivas formas de tratamento; correlação é feita com a artroplastia propriamente dita em humanos, destacando principalmente a cirurgia, primeira cirurgia de revisão, segunda cirurgia de revisão e o recapeamento com sua posterior evolução, mostrando um breve histórico de reconstrução de quadril de cães.

\subsection{1- Articulação do Quadril do Cão}

Para uma melhor compreensão sobre o estudo deste trabalho, torna-se necessário o conhecimento da anatomia da região anatômica canina que se deseja estudar (quadril). A Figura 2.1 mostra parte da anatomia da articulação do quadril a qual é objeto de estudo deste trabalho. A articulação do quadril é a articulação entre a cabeça do fêmur e o acetábulo. É uma articulação sinovial que permite vários movimentos compatíveis com uma ampla variedade de atividades locomotoras. Esta articulação permite a conexão do membro inferior ao tronco e, por esta razão auxilia na transmissão de peso. A estabilidade desta articulação se dá pela própria anatomia de sua superfície articular (um acetábulo profundo que segura firmemente à cabeça femoral) pela resistência da cápsula articular e dos ligamentos associados e pela inserção dos músculos que passam pela articulação, os quais ficam afastados do centro de movimento (PALASTANGA et al., 2000). 


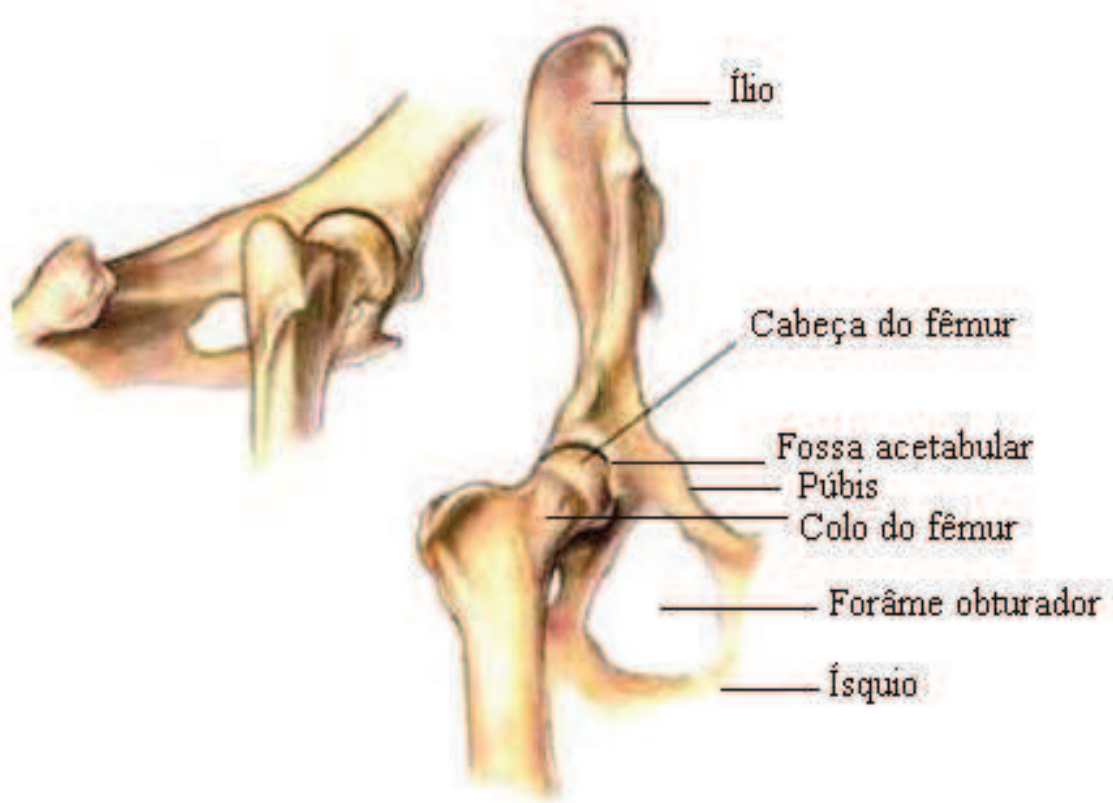

Figura 2.1- Articulação do quadril do cão

[ABUD, 2010].

Devido as suas múltiplas funções, o osso do quadril tem uma estrutura complexa e sua formação envolve três ossos isolados: o ílio, o ísquio e o púbis. Essas três peças ósseas se unem na região onde mais se faz sentir o peso suportado pelo osso do quadril, isto é, o centro do acetábulo, fossa acetabular que recebe a cabeça do fêmur. Assim, é nesse ponto que se dá a união entre o esqueleto apendicular do membro inferior e a cintura pélvica (DÂNGELO; FATTINI, 1998).

O fêmur canino, tanto como o humano, transmite o peso do corpo a partir do ílio para a extremidade superior da tíbia. É o osso mais longo, mais pesado e mais forte no corpo e possui uma diáfise e duas epífises. A extremidade proximal é constituída pela cabeça do fêmur, colo do fêmur, trocânter maior e trocânter menor. Enquanto a extremidade distal é composta pelo epicôndilo medial e lateral, côndilo medial e lateral, fossa intercondilar e face patelar (DÂNGELO; FATTINI, 1998; SILVESTRE FILHO, 2006). A Figura 2.2 ilustra as principais partes do fêmur canino. 
Extremidade proximal

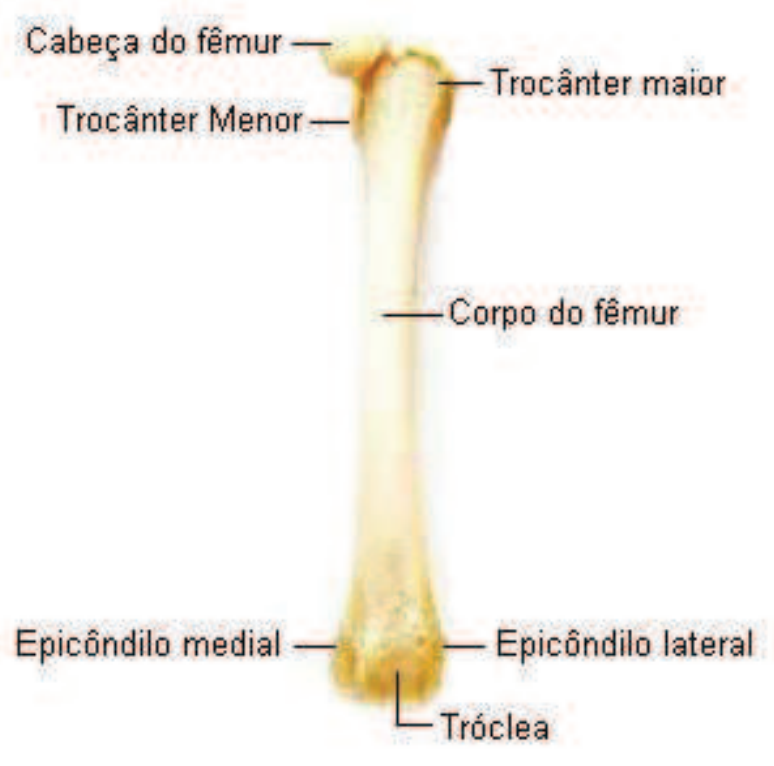

Extremidade distal

Figura 2.2- Fêmur de cão. [DOWELL, 2010].

O fêmur possui uma cabeça circular que se articula com o acetábulo; estes se localizam em um eixo oblíquo ao eixo do fêmur. O eixo proximal tem duas tuberosidades: o trocânter maior lateral ao colo e o trocânter menor inferior e posterior ao colo. Os sulcos intertrocântéricos posteriores formam uma cavidade com a superfície posterior do colo femoral, a fossa intertrocântérica. Ao longo desta crista encontra-se o tubérculo do quadrado. Essas cristas e proeminências servem de inserção para músculos que controlam o movimento do quadril. Na sua superfície inserem-se os músculos extensores do joelho; na superfície posterior encontram-se as cristas e proeminências, na região póstero-lateral rugosa e abaixo da metade da diáfise encontra-se uma proeminência, a linha áspera. A linha supra condilar medial corre ao longo do tubérculo adutor que pode ser palpado. $\mathrm{Na}$ extremidade distal do fêmur encontram-se os côndilos medial e lateral, que fazem parte da articulação do joelho. A parede externa do fêmur que é formada por osso cortical, é mais delgada e a cavidade medular é maior (SEELEY; STEPHENS; TATE, 1997).

A cabeça do fêmur articula-se intimamente com o acetábulo e forma a articulação coxofemoral propriamente dita. O acetábulo é acentuado no seu rebordo por um cordão fibrocartilagíneo chamado debrum cotiloideu, inferiormente incompleto e por um ligamento transverso do acetábulo que cruza a chanfradura ísquio-púbica no bordo inferior do acetábulo (SEELEY; STEPHENS; TATE, 1997). 
O ílio é o maior dos três ossos e tem formato triangular, sendo que seu ângulo externo (tuberosidade pélvica) forma a ponta do quadril. $O$ ísquio forma a parte posterior do assoalho da pélvis e seu bordo medial se encontram com o osso do lado oposto na sínfise isquiática. O púbis é o menor dos três ossos e forma a parte anterior do assoalho da pelve. A borda medial se une com o osso do lado oposto ao nível da sínfise púbica. Os três ossos se encontram para formar o acetábulo que é uma cavidade que se articula com a cabeça do fêmur. Articula-se por cima com o acetábulo (pelve) e por baixo com a tíbia e patela (FERREIRA, 2010). Em um cão normal, a cápsula articular encaixa-se firmemente ao redor da borda acetabular e se prende ao redor da circunferência do colo imediatamente distal à junção da cabeça e do colo. O ligamento da cabeça femoral corre entre a fossa acetabular e a fóvea da cabeça femoral. Com o fêmur visto na posição cranial, o ângulo de inclinação é o ângulo formado entre a linha que bissecciona o eixo longitudinal femoral e a linha que bissecciona o colo femoral. No cão normal esse ângulo é de $135^{\circ}$ a $145^{\circ}$ graus. O fêmur tem um ângulo de anteversão que nos cães normais é de $20^{\circ}$ a $27^{\circ}$ graus. As Figuras 2.3 e 2.4 ilustram a pelve de cães.

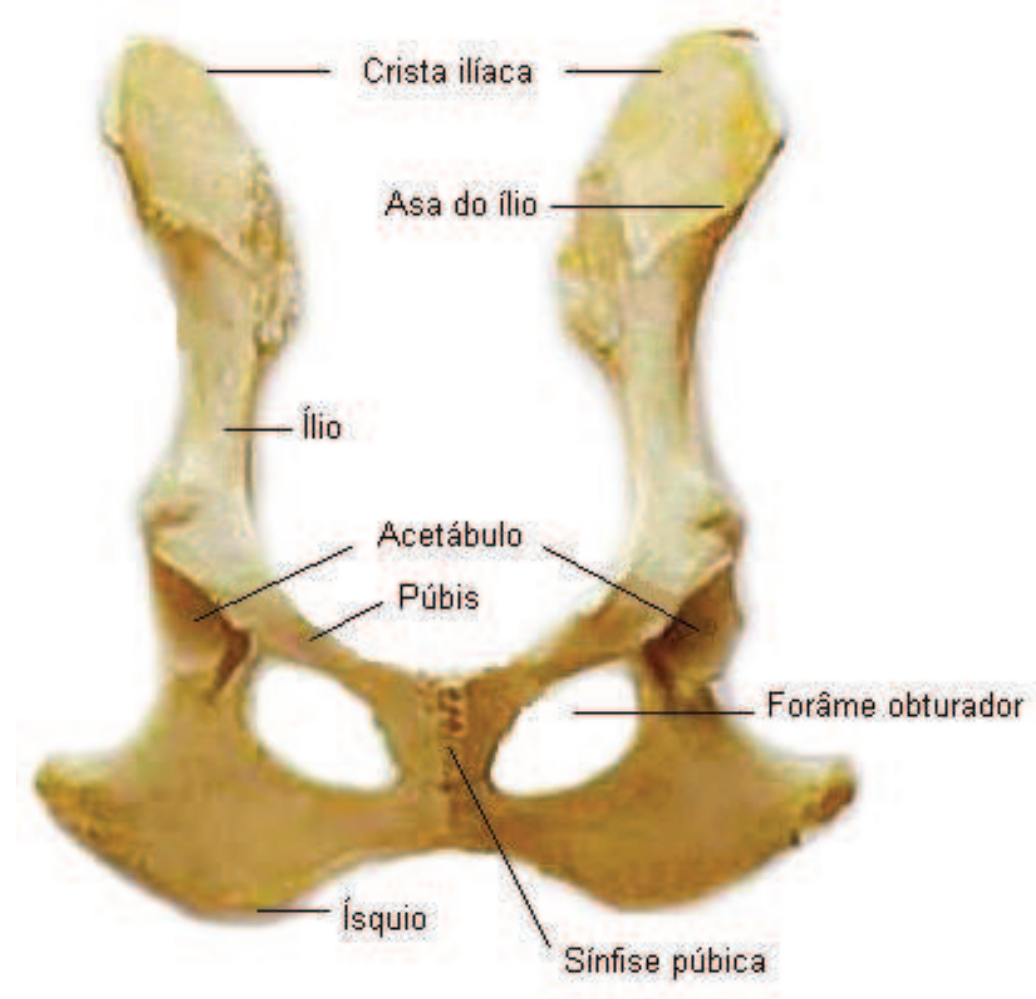

Figura 2.3- Pelve canina. [DOWELL, 2010]. 


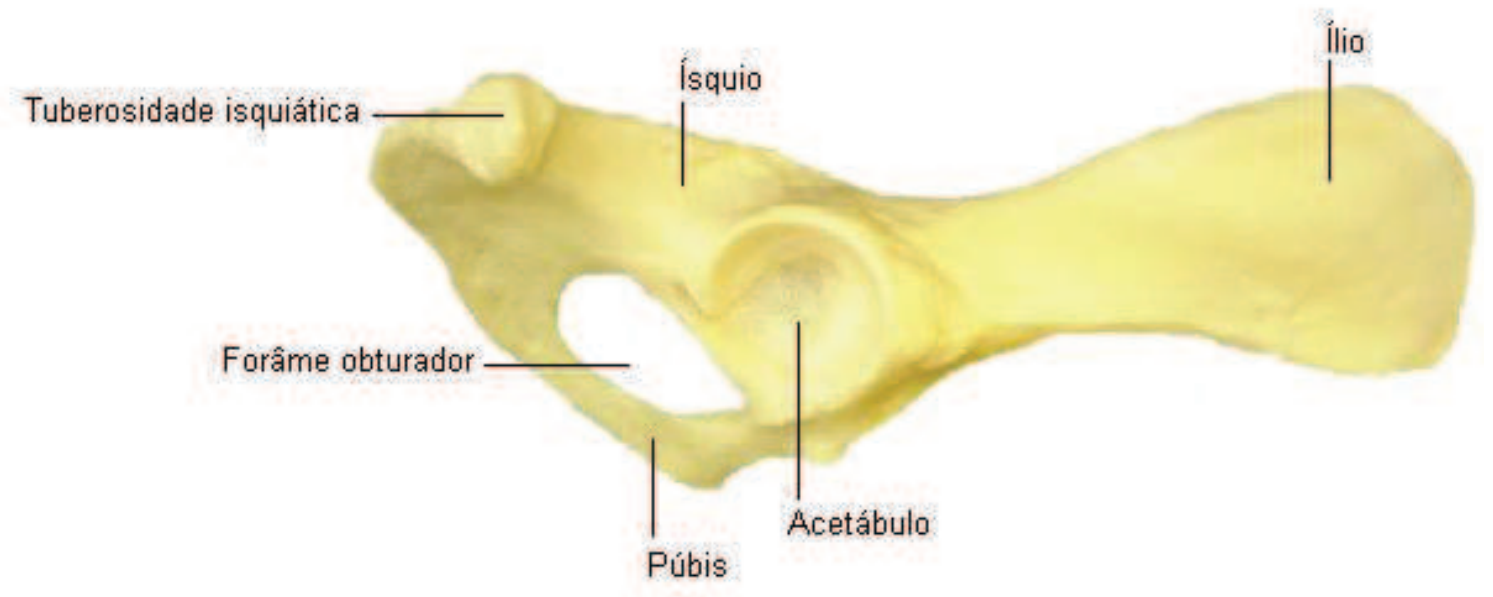

Figura 2.4- Quadril de cão.

Cook, Tomlinson e Constantinescu (1996) descreveram que a carga (força) sobre a articulação coxofemoral é determinada pelo peso do animal, conformação e atividade. Quando um cão está em estação (em pé), 30 a $40 \%$ do peso corporal está distribuído sobre os membros pélvicos. Durante a movimentação, no entanto, a articulação coxofemoral pode sustentar três vezes o peso corporal.

A quantidade de força imposta à articulação coxofemoral é influenciada pelo ângulo de inclinação do fêmur ou ângulo cérvico-diafisário (Figura 2.5). Esse ângulo é formado pela junção da cabeça e colo na região proximal do fêmur sendo biomecanicamente importante na transferência de forças do fêmur para o acetábulo. Um aumento ou diminuição neste ângulo ocasiona mudanças correspondentes nas forças intra-articulares e podem contribuir para as alterações pato-fisiológicas da displasia coxofemoral (DCF) que é uma patologia do desenvolvimento de etiologia complexa que acomete o homem e a maioria dos animais domésticos. É um sério problema de saúde tanto em cães quanto em humanos, embora a freqüência seja maior em cães. Em contraste com uma incidência de 1\% em humanos (PETERSEN, 2003), a DCF pode ocorrer em mais de $50 \%$ dos cães de raças grandes. Outra diferença da DCF entre homens e cães, é que a DCF no cão é uma doença hereditária, mas não congênita: o cão não nasce com displasia, mas adquire devido à influência de muitos fatores como ambientais, alimentares, excesso de exercícios entre outros (SANTOS, 2010).

A palavra "displasia" significa desenvolvimento anormal ("dys" em grego significa anormal e "plassein" formação). É uma doença biomecânica na qual a instabilidade do quadril em cães jovens altera a concentração de forças no fêmur e acetábulo em crescimento, afetando o desenvolvimento ósseo e resultando em conformação articular 
anormal e doença articular secundária (HAUPTMAN; CARDINET; MORGAN, 1985; KAPATKIN; FORDYCE; MAYHEW, 2002; SMITH, 2004; WALLACE, 1987).

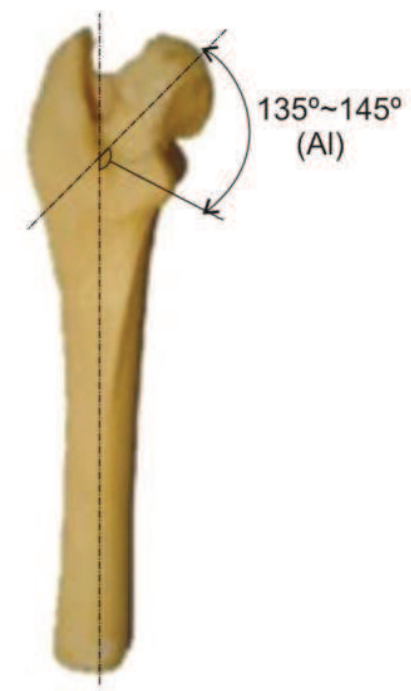

Figura 2.5- Desenho esquemático do fêmur de cão, ilustrando o ângulo de inclinação (Al). Adaptado de [WEIGEL e WASSERMAN,1992].

Os valores médios relatados do ângulo de inclinação variam em função do método de mensuração. $O$ valor médio do ângulo de inclinação de cães normais mensurado pelo método A, descrito por Hauptman et al. (1979) era $146,2^{\circ} \pm 4,8^{\circ}$, enquanto pelo método $B$ era $129,4^{\circ} \pm 4,9^{\circ}$. O método $A$ é mais preciso de acordo com os autores, pois o método $B$ incorpora uma crista de osso entre o trocânter maior e a cabeça do fêmur, ocasionando maior possibilidade de erro na mensuração. Schawalder e Sterchi (1981) observaram que o ângulo de inclinação varia em função da raça do animal. O valor médio do ângulo de inclinação de cães normais das raças Pastor Alemão e São Bernardo mensurado pelo método biplanar é da ordem de $147,5^{\circ}$ e $154,3^{\circ}$, respectivamente.

O ângulo de inclinação está correlacionado com o ângulo de anteversão. O ângulo de anteversão corresponde ao ângulo formado entre a cabeça e o colo femoral em relação aos côndilos do fêmur no plano transverso (Figura 2.6). O ângulo de anteversão médio relatado em cães normais é $26,97^{\circ}$. Quanto maior o ângulo de anteversão, maior será o ângulo de inclinação mensurado na radiografia. O ângulo de inclinação real deve ser calculado com a cabeça e o colo femoral em $0^{\circ}$ de anteversão (HAUPTMAN et al., 1985). 


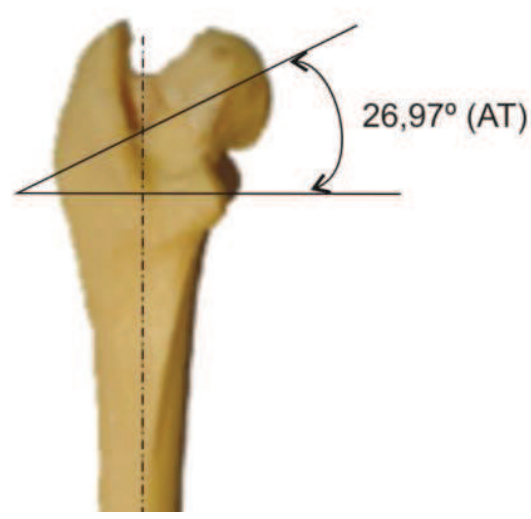

Figura 2.6- Desenho esquemático do fêmur de cão, ilustrando o ângulo de anteversão (AT).

Adaptado de [WEIGEL e WASSERMAN,1992].

O aumento do ângulo de inclinação (coxa valga) resulta na diminuição da distância entre a cabeça e o trocânter maior do fêmur. Conseqüentemente, os músculos abdutores do quadril exercem uma maior força para manter o equilíbrio da articulação coxofemoral. À medida que os músculos exercem mais força para manter a articulação na posição, essa força é aplicada aos ossos da articulação coxofemoral, resultando em aumento da força sobre a cabeça do fêmur (Figura 2.7). Este estresse anormal sobre a articulação coxofemoral potencializa a frouxidão articular, a incongruência e a doença articular degenerativa (DAD) (ARNOCZKY; TORZILLI, 1981; COOK; TOMLINSON; CONSTANTINESCU, 1996; TOMLINSON; McLAUGHLIN JR., 1996; WEIGEL; WASSERMAN, 1992). 


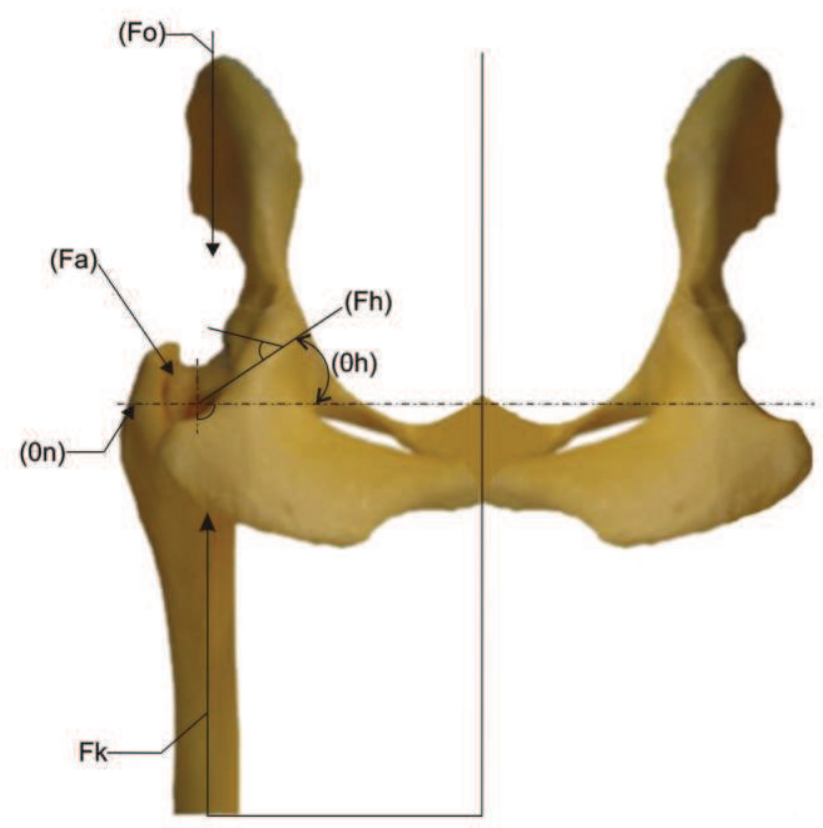

Figura 2.7- Desenho esquemático da articulação coxofemoral de cão, ilustrando as forças que agem sobre a articulação do quadril no plano transverso. Fa= força dos músculos abdutores; $F_{0}=$ peso corporal; Fk=força de reação do solo; Fh= força total sobre a articulação coxofemoral. Os ângulos importantes a serem considerados são o ângulo de inclinação $(\theta n)$ e o ângulo da força total do quadril $(\theta h)$. $O$ aumento do ângulo de inclinação $(\theta n)$ resulta em aumento na força dos músculos abdutores (Fa) e conseqüentemente no aumento da força sobre a cabeça do fêmur (Fh).

Adaptado de [ARNOCZKY e TORZILLI, 1981].

A DCF é uma das principais doenças ortopédicas que foi pesquisada por Hauptman et al. (1985) que concluíram que o ângulo de inclinação não interfere no desenvolvimento da DCF, pois não foi observada diferença significativa entre o ângulo de inclinação de animais normais $\left(143,1^{\circ} \pm 0,4^{\circ}\right)$ e displásicos $\left(142,8^{\circ} \pm 0,7^{\circ}\right)$. Tanto a geometria óssea quanto a densidade mineral são importantes nas propriedades biomecânicas do osso (BRIANZA; DELISE; FERRARIS, 2006). O esqueleto possui a incrível capacidade de redefinir sua massa e sua morfologia para se adaptar à demanda funcional e metabólica. A predeterminação genética da forma e da estrutura (cortical e medular) de cada osso, o formato ósseo, a anatomia e as propriedades mecânicas como rigidez e força são adaptadas através de estímulos mecânicos que ocorrem durante toda a vida do animal (SOMMERFELDT; RUBIN, 2001; TAYLOR et al., 1996). Nota-se que, em casos de doenças esqueléticas, a proporção entre osso compacto e osso esponjoso pode alterar consideravelmente. A relação entre o diâmetro da cavidade medular de um osso e a espessura de sua cortical reflete a estrutura do osso, e pode ser quantificada através do cálculo do índice cortical. O valor do índice cortical pode mudar em casos de doenças 
sistêmicas ou em resposta às forças biomecânicas atuantes sobre o osso (HARTUNG; HASSELT, 1988; LOVERIDGE, 1999).

Palierne, Asimus e Mathon (2006) descreveram que a espessura da cortical está associada à rigidez do osso e esta rigidez depende da quantidade de forças que esse osso é submetido. No fêmur normal, as corticais mediais estão principalmente sob efeito de forças de compressão, enquanto as corticais laterais estão sob efeito das forças de tração (PAGE; ALLAN; JASTY, 1993). As forças de compressão promovem deposição e produção de osso, resultando no aumento da espessura cortical, enquanto as forças de tração estimulam a reabsorção e conseqüente diminuição da espessura cortical (PERNEL; GROSS; MILTON, 1994).

\subsection{Atualidades na Ortopedia Veterinária}

Nesta seção, é apresentada uma revisão sobre o que acontece atualmente na ortopedia veterinária de um modo geral em relação ao tratamento das patologias que afetam a articulação coxofemoral canina (fêmur e acetábulo), com seus respectivos tratamentos cirúrgico (protocolos); também é mostrado uma revisão sobre as próteses cirúrgicas atualmente utilizadas para artroplastia de quadril e ainda, são apresentados os materiais e ferramentais utilizados para este tipo de cirurgia em cães.

\subsection{Patologias do Quadril do Cão x Tratamento Cirúrgico}

Os cães de um modo geral são classificados de acordo com sua estatura e peso em raças de pequeno médio e grande porte. Sendo assim, algumas patologias de quadril se tornam específicas para cada grupo de animais. As principais patologias que acometem a articulação do quadril do cão são a de necrose asséptica da cabeça do fêmur, a displasia coxofemoral e a ruptura do ligamento redondo.

Geralmente os animais de pequeno porte tais como o Poodle, Pincher, Lakeland Terrier, Manchester Terrier apresentam uma patologia específica da cabeça femoral denominada de necrose asséptica da cabeça do fêmur ou afecção de Legg-Calvé-Pethers, acometendo animais entre 3 a 11 meses de idade, uni ou bilateralmente. Esta doença se caracteriza radiograficamente por áreas irregulares com lise na cabeça femoral provocando um alargamento do espaço articular que posteriormente provoca o colapso da cabeça 
femoral. As alterações ósseas iniciais na necrose asséptica idiopática no cão não são demonstradas radiograficamente; são limitadas a um tênue aumento da densidade óssea da epífise femoral proximal afetada. Um espessamento trabecular e a formação de osso subcondral compacto continuam até que haja evidência de um leve aumento da densidade da cabeça femoral (KEALY; McALLISTER 2000; STURION; STURION, 2006).

O tratamento preconizado por Sturion et al, (2006) para animais que apresentam necrose asséptica na cabeça do fêmur é o cirúrgico, através da artroplastia por excisão da cabeça e colo femorais por abordagem dorso-caudal, que consiste em uma incisão elíptica da pele tendo como referência o trocânter maior conforme ilustra a Figura 2.8. Em seguida é realizada uma incisão da fáscia lata (Figura 2.9) e a inserção do músculo tensor da fáscia lata com músculo glúteo médio, com o afastamento caudal dos músculos glúteo superficial, bíceps femoral e do nervo ciático Figura (2.10). É então realizada uma incisão dos músculos gêmeos e da capsula articular dorsal (Figura 2.11), e do ligamento redondo da cabeça femoral caso este esteja integro. Para exposição da cabeça femoral, é necessária uma rotação do membro no sentido caudal (Figura 2.12) onde se obtém uma melhor exposição da cabeça femoral e realização da excisão propriamente dita com uma cizalha (Figura 2.13). Nos casos onde há sobras de resquícios ou margens ósseas irregulares, estas podem ser removidas com o auxilio de goivas ou curetas.

Figura 2.8- Acesso dorso-caudal à articulação coxofemoral, incisão da pele em forma elíptica tendo como referencia o trocânter maior. [STURION et al, 2006].

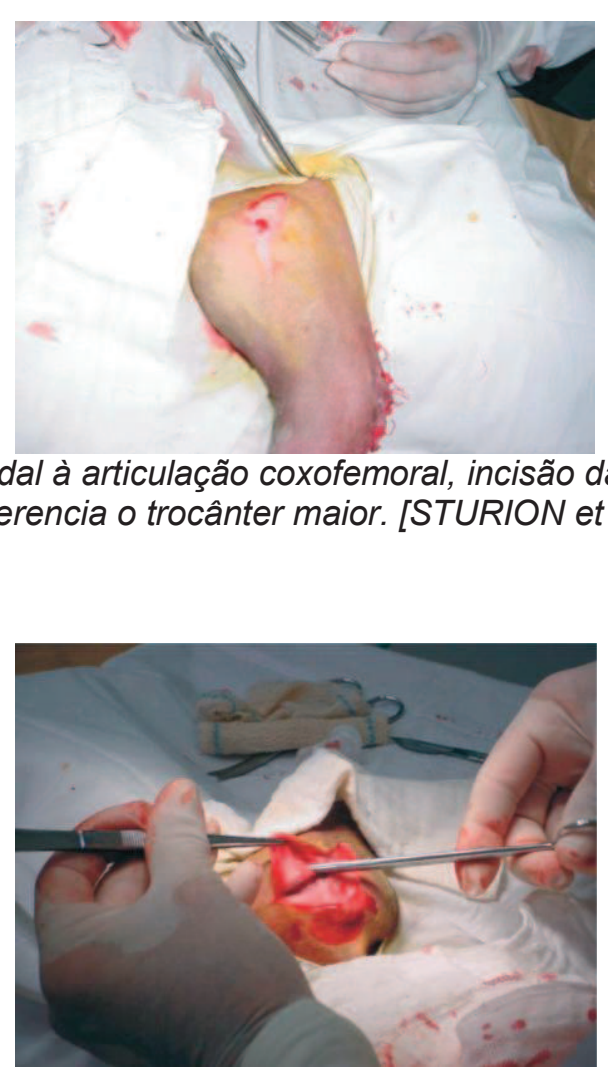

Figura 2.9- Incisão da fáscia lata para visualização da inserção do músculo tensor da fáscia lata com o músculo glúteo médio. [STURION et al, 2006]. 


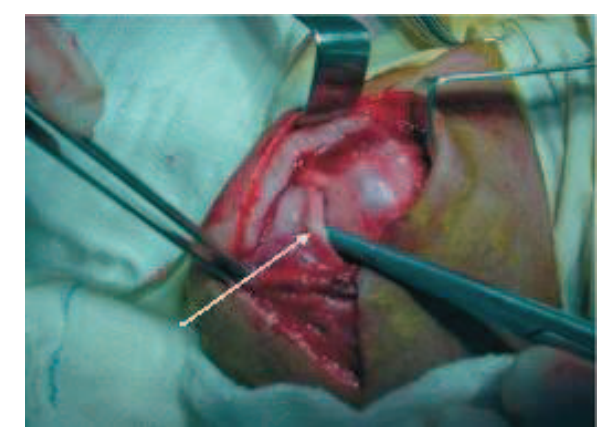

Figura 2.10- Afastamento caudal do nervo ciático. [STURION et al, 2006].

Figura 2.11- Incisão dos músculos gêmeos e cápsula articular dorsal, para exposição da cabeça femoral. [STURION et al, 2006].

Figura 2.12- Rotação do membro pélvico no sentido caudal para exposição da cabeça e colo femoral. [STURION et al, 2006].

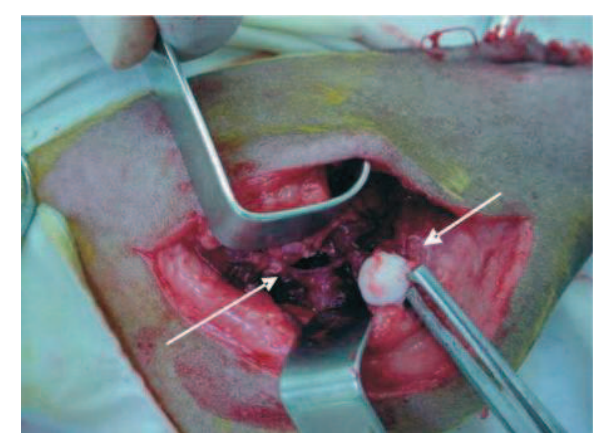

Figura 2.13- Excisão e exposição da cabeça femoral. [STURION et al, 2006]. 
Apesar de ser preconizado por muitos autores o acesso crânio lateral para a realização da artroplastia excisional da cabeça femoral, este acesso apresenta alguma dificuldade na exposição e exteriorização da cabeça femoral, devido à tensão oferecida pelo músculo glúteo médio (PIERMATTEl; GREELEY, 1979; BEARZON et al., 1980; GAMBERDELLA, 1981; LIPPINCOTT, 1981; DAVID, 1985; BRINKER et al., 1999; HON; JANES, 1983; FOSSUM, 2002).

A displasia coxofemoral em cães é a patologia ortopédica mais freqüentemente encontrada em cães de médio e grande porte nas clínicas veterinárias, sendo a principal causa de osteoartrite da articulação coxofemoral, podendo ocorrer uni ou bilateralmente.

A displasia coxofemoral refere-se a um desenvolvimento anormal da articulação e é caracterizado principalmente por frouxidão articular (JOHNSON; HULSE, 2002).

Várias são as formas de tratamento para a displasia coxofemoral canina, porém uma técnica que deveria ser utilizada por cirurgiões veterinários no Brasil seria através da colocação de próteses metálicas denominadas de prótese total da articulação coxofemoral cimentada, porém, possuem alto custo e são produzidas tanto no Brasil como no exterior.

Nos Estados Unidos e na maioria dos países da Europa a utilização de prótese total da articulação coxofemoral é considerada uma das técnicas mais indicada para o tratamento cirúrgico desta patologia que dificulta a locomoção dos animais domésticos e gera dor intensa. Já no Brasil, esta técnica ainda é pouco difundida, pois pouco são os cirurgiões que possuem treinamento especializado para tal prática, além de que, a utilização dos componentes protéticos torna o procedimento muito oneroso. Esta técnica pode ser vista no modelo de resina ilustrado na Figura 2.14.

A artroplastia total é recomendada para o tratamento da displasia coxofemoral crônica e potencialmente dolorosa, especialmente por preservar a função do membro, restabelecendo mecanismos articulares sem dor (OLMSTEAD, 1987).

Um trabalho realizado por Minto et al (2008), relata o tratamento experimental em cães com a técnica de artroplastia total coxofemoral testando próteses nacionais metálicas. O acesso cirúrgico realizado foi através da abordagem craniolateral da articulação coxofemoral. Em seguida, foi realizada uma osteotomia do colo femoral para receber a prótese nacional cimentada, composta por um componente acetabular confeccionado em polietileno de alta densidade, apresentando sistema retensivo e um componente femoral de cromo-cobalto com cabeça fixa. O acetábulo foi aprofundado, cerca de 5,0 a 10,0 mm, com raspa hemisférica específica, removendo-se toda a cartilagem articular. Três ou mais orifícios, nas bordas ilíaca, isquiática e dorsal do acetábulo, foram realizados com o auxílio de uma perfuratriz e broca cirúrgica, a fim de ampliar a superfície de contato entre o cimento ósseo à base de polimetilmetacrilato e o osso. A prótese acetabular foi cimentada, 
utilizando-se posicionador específico, acompanhando as angulações anatômicas do acetábulo. Uma fresa afilada específica foi utilizada para a preparação do canal femoral. Em seguida, a prótese femoral foi cimentada em ângulo neutro de anteversão, acompanhando o eixo transversal dos côndilos femorais. Após os testes da articulação protética, os tecidos musculares e pele foram suturados. Não foram disponibilizadas as imagens operatórias referente à técnica cirúrgica dos animais, porém, a Figura 2.15 mostra as imagens radiográficas da articulação coxofemoral de um cão após 90 dias do pós-operatório com a presença da prótese total e a Figura 2.16 revela a soltura do componente protético após três dias do pós-operatório.

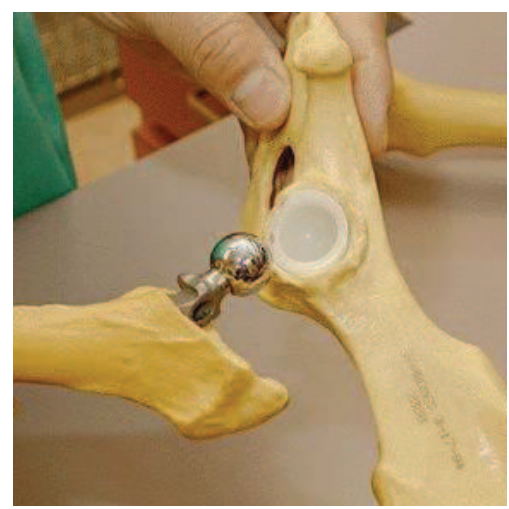

Figura 2.14- Modelo em resina da aplicação de prótese total de quadril de cães. [JUNIOR, 2011].

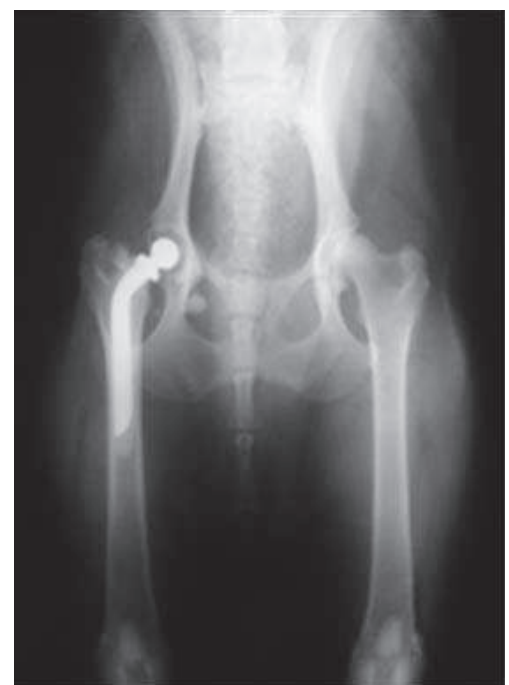

Figura 2.15- Radiografia da articulação de um cão 90 dias após a colocação da prótese total [MINTO et al, 2008]. 


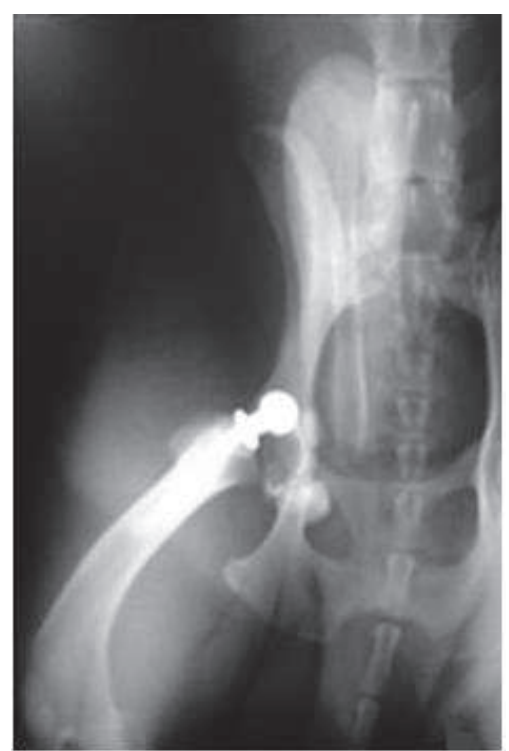

Figura 2.16- Radiografia mostrando a soltura do componente protético três dias após sua colocação [MINTO et al, 2008].

\subsection{Próteses cirúrgicas utilizadas para artroplastia de quadril de cães}

Atualmente, o tratamento das patologias articulares de quadril dos cães onde há necessidade de utilização de próteses metálicas é denominado de prótese total de quadril. Existem vários tipos de próteses totais de quadril de cães disponíveis, tanto no Brasil como nos Estados Unidos e podem ser classificados como cimentados e não cimentados. A escolha de qual técnica a ser utilizada vai depender da habilidade do cirurgião. A prótese cimentada, conforme mostra a Figura 2.17, é aquela onde a haste é aderido ao canal femoral através de um cimento ósseo composto de polimetilmetacrilato; já na prótese não cimentada, na Figura 2.18, os componentes são aderidos através do processo denominado de osteointegração. 


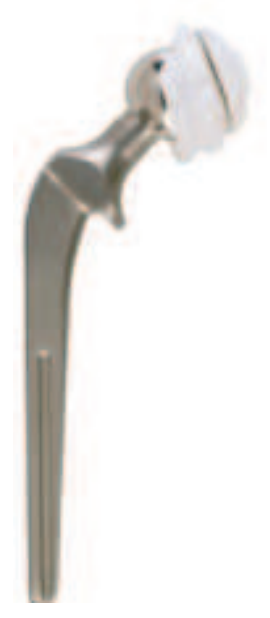

Figura 2.17- Prótese total de quadril cimentada [HAYASHI, 2009].

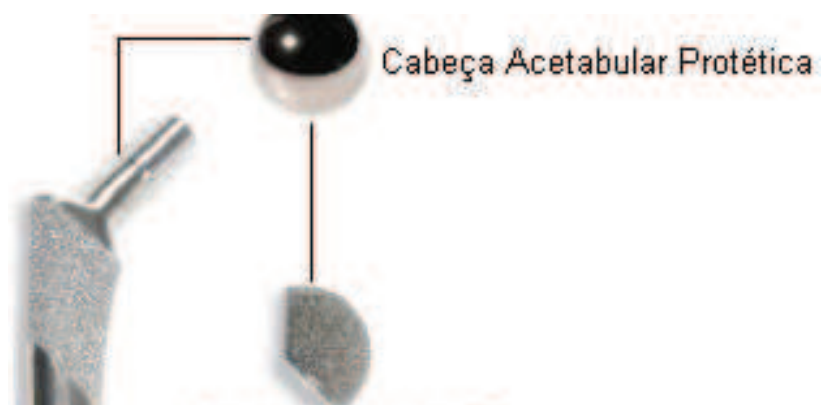

Cúpula Acetabular Porosa

Haste Femoral Porosa

As próteses totais de quadril de cães disponíveis no mercado são constituídas basicamente de uma cúpula acetabular de alta densidade e de componentes femorais (cabeça, colo e haste) de liga metálica de cromo-cobalto, aço inoxidável ou titânio. As hastes femorais, cúpulas acetabulares e as cabeças protéticas apresentam-se comercialmente em diversos tamanhos.

Nos Estados Unidos, a Biomedtrix® fabrica Próteses cirúrgicas para cães tanto cimentada como não cimentada. As tabelas 2.1, 2.2 e 2.3 mostram os tipos e tamanhos de próteses de quadril para raças de tamanho diferentes (médias, grandes, pequenas e micro) desenvolvidas pela Biomedtrix ${ }^{\circledR}$ que são utilizados atualmente.

Tabela 2.1- Raças médias e grandes [BIOMEDTRIX..., 2010].

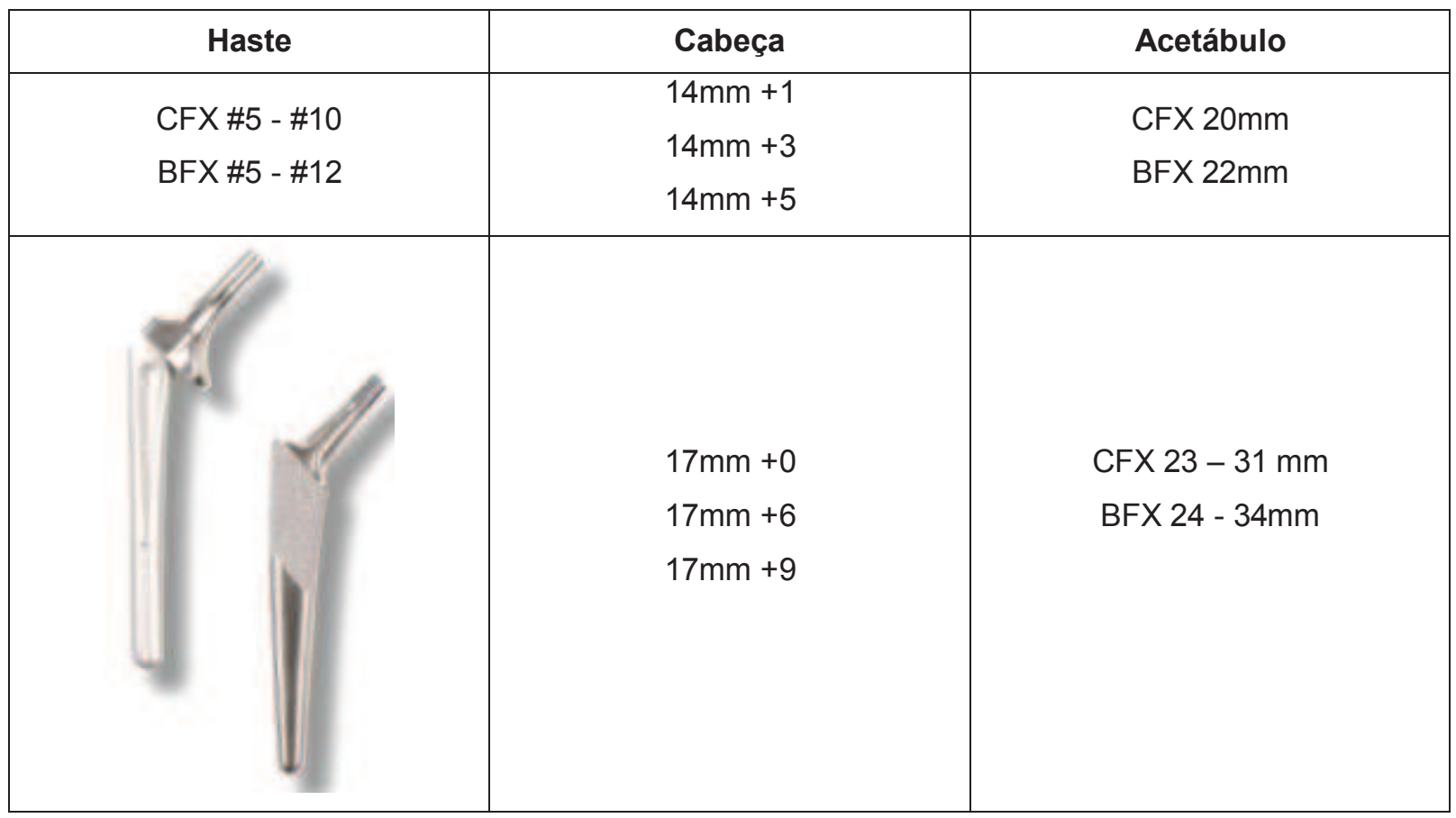


Tabela 2.2- Raças pequenas [BIOMEDTRIX..., 2010].

\begin{tabular}{|c|c|c|}
\hline Haste & Cabeça & Acetábulo \\
\hline $\begin{array}{l}\text { CFX\#4 } \\
\text { BFX\#5 }\end{array}$ & $\begin{array}{l}12 \mathrm{~mm}+0 \\
12 \mathrm{~mm}+3\end{array}$ & $\begin{array}{l}\text { CFX } 18 \mathrm{~mm} \\
\text { BFX } 20 \mathrm{~mm} \\
\text { BFX } 22 \mathrm{~mm}\end{array}$ \\
\hline CFX\#4/\#5 & $\begin{array}{l}14 \mathrm{~mm}+1 \\
14 \mathrm{~mm}+3 \\
14 \mathrm{~mm}+5\end{array}$ & $\begin{array}{l}\text { CFX } 20 \mathrm{~mm} \\
\text { BFX } 22 \mathrm{~mm}\end{array}$ \\
\hline$H$ & $\begin{array}{l}17 \mathrm{~mm}+0 \\
17 \mathrm{~mm}+3 \\
17 \mathrm{~mm}+6 \\
17 \mathrm{~mm}+9\end{array}$ & CFX 23 \\
\hline
\end{tabular}

Tabela 2.3- Raças Micro [BIOMEDTRIX..., 2010].

\begin{tabular}{|c|c|c|}
\hline Haste & Cabeça & Acetábulo \\
\hline CFX Micro\#2-\#3 & & \\
& & CFX 12mm \\
& $8 \mathrm{~mm}+0$ & CFX 14mm \\
& $8 \mathrm{~mm}+2$ & CFX 16mm \\
& & \\
\hline
\end{tabular}




\subsection{Ferramental cirúrgico e Materiais utilizados para artroplastia total de quadril em cães}

Atualmente no Brasil, a técnica cirúrgica utilizada pelos cirurgiões na ortopedia veterinária para tratamento das patologias da articulação do quadril de cães, onde o uso de componentes protéticos se faz necessário, é a artroplastia total cimentada. Para a realização desta cirurgia, torna-se necessário um conjunto de ferramentais específicos como o ilustrado na Figura 2.19, que por sua vez é fabricado pela Biomedtrix $®$ nos Estados Unidos e o Brasil, a Brasmed também fabrica instrumental para artroplastia total de quadril de cães (ANEXO 1). Outros ferramentais auxiliares são importantes para artroplastia de quadril de cães, como a serra pneumática (Figura 2.20) ou fio serra (Figura 2.21) para osteotomia da cabeça e colo femoral, furadeira de baixa rotação (Figura 2.22), e materiais que são utilizados para a realização do processo de cimentação dos componentes protéticos (femoral e acetabular) como o cimento ósseo acrílico (Figura 2.23), material este que fará com que a haste e o colo permaneçam em contato com o canal femoral promovendo estabilidade das próteses cirúrgicas. Embora o cimento ósseo acrílico seja um dos materiais mais utilizados para fixação de próteses cirúrgicas e implantes, produz conseqüências futuras à cirurgia propriamente dita e ao sítio cirúrgico, em particular ao tecido ósseo, pois a reação química desse material é exotérmica, podendo atingir até $80^{\circ} \mathrm{C}$, o que produz a osteólise dos tecidos adjacentes. Como esse aspecto cirúrgico não faz parte dos objetivos deste trabalho, ficam aqui relatadas somente essas informações largamente citadas na literatura específica. 


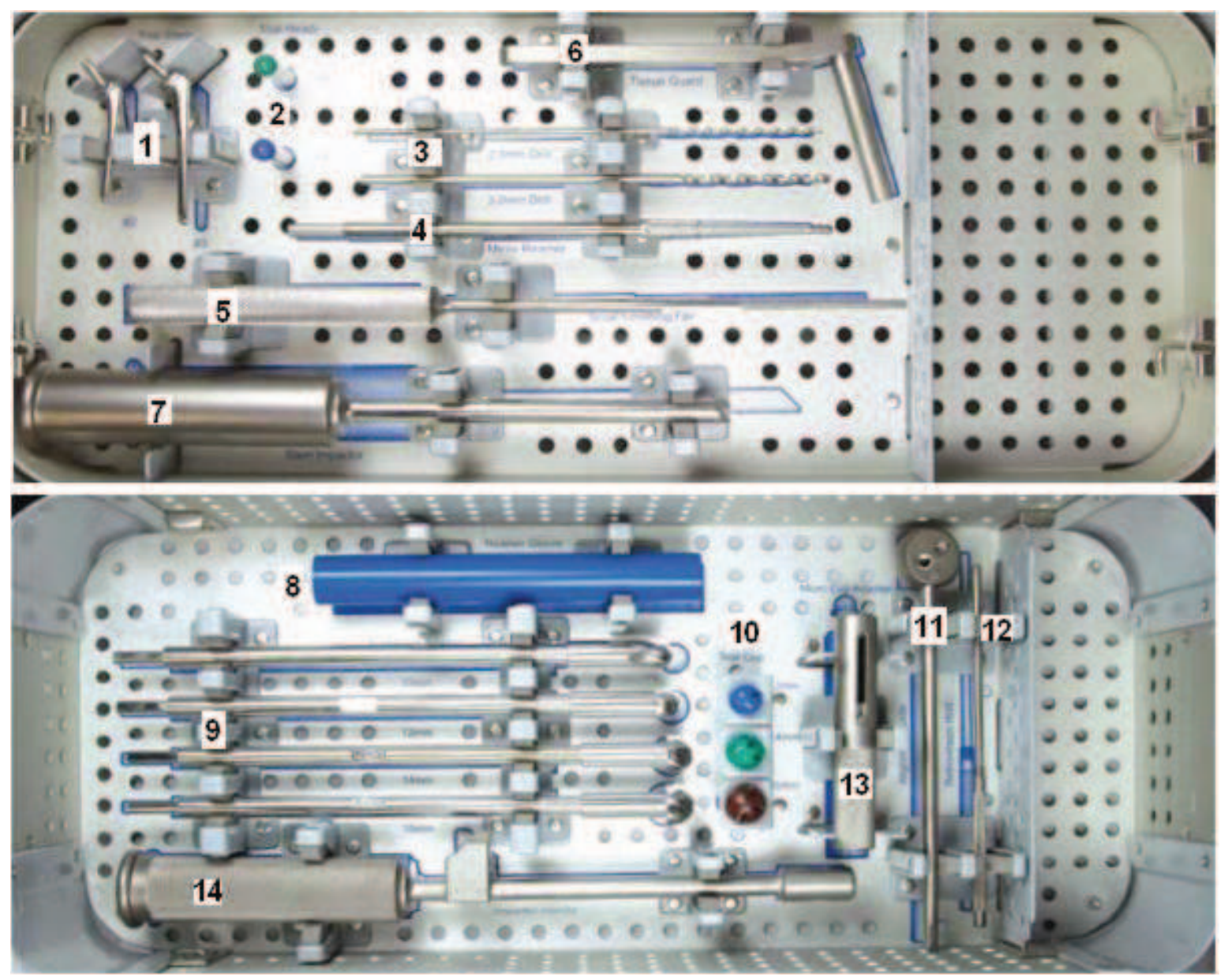

\begin{tabular}{|c|l|}
\hline Número do produto & \multicolumn{1}{|c|}{ Descrição do produto } \\
\hline 1 & Haste femoral \\
\hline 2 & Dispositivo para julgamento de cabeça femoral \\
\hline 3 & Broca \\
\hline 4 & Alargador cônico \\
\hline 5 & Auxiliar de acabamento \\
\hline 6 & Protetor de tecido \\
\hline 7 & Impactador \\
\hline 8 & Alargador \\
\hline 9 & Alargador acetabular \\
\hline 10 & Dispositivo para julgamento acetabular \\
\hline 11 & Guia de alinhamento \\
\hline 12 & Guia de retroversão \\
\hline 13 & Punho impactador \\
\hline 14 & Adaptador de cúpula acetabular \\
\hline
\end{tabular}

Figura 2.19- Instrumental cirúrgico utilizado para realização de artroplastia total de quadril em cães. [BIOMEDTRIX, 2010] 


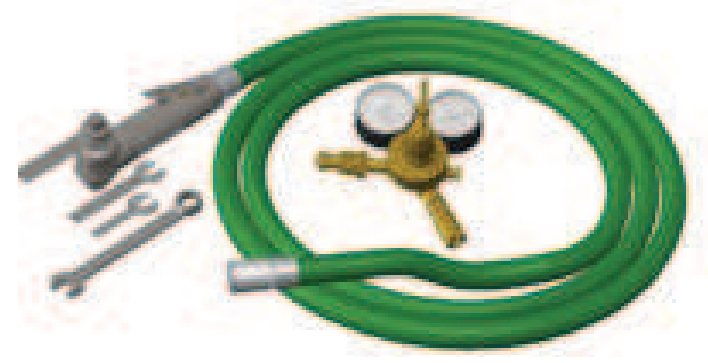

Figura 2.20- Serra pneumática autoclavável utilizada para osteotomia de cabeça e colo femoral. [ORTOP, 2011].

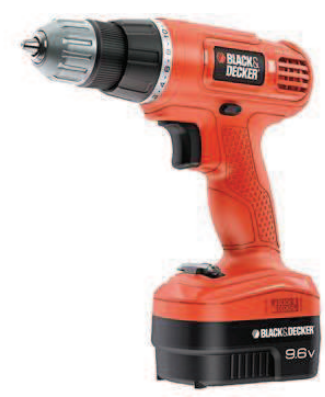

Figura 2.22- Furadeira de baixa rotação utilizada na ortopedia veterinária.

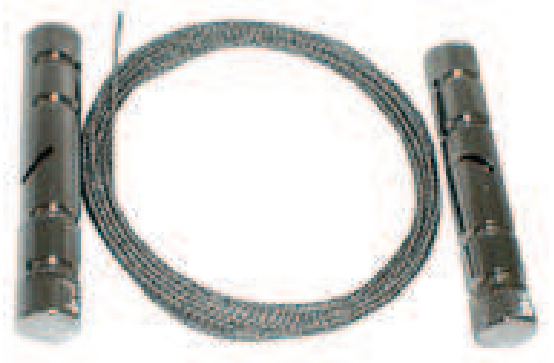

Figura 2.21- Fio serra utilizado para osteotomia de cabeça e colo femoral. [BRASMED, 2011].

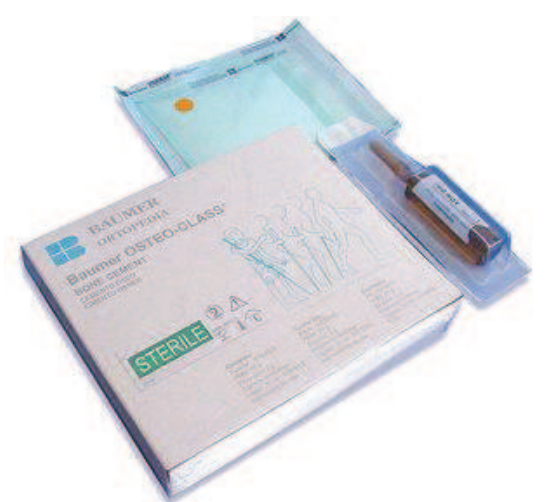

Figura 2.23- Cimento ósseo acrílico utilizado para fixação de próteses metálicas de quadril. [BAUMER, 2011].

\subsection{Procedimentos realizados na artroplastia total de quadril de cães}

Com os instrumentais disponíveis e devidamente preparados o cirurgião poderá iniciar o processo a técnica de artroplastia total propriamente dita a qual se inicia com a osteotomia da cabeça e colo femoral afetada com o auxílio da serra pneumática ou através de um fio serra. Após a exposição do canal medular femoral, é necessário que o cirurgião aumente este canal medular com brocas para a pré-colocação da haste medular que será fixada através do uso de cimento ósseo acrílico mantendo sua estabilidade e evitando sua soltura posterior. A fossa acetabular também recebe tratamento logo; esta é aprofundada com o auxilio de um alargador acetabular acoplado a uma furadeira e em seguida, é aplicado sobre a superfície acetabular uma camada de cimento ósseo acrílico para fixação da prótese acetabular. Estruturas ósseas que ainda permaneçam ao redor do acetábulo ou até mesmo no fêmur são removidas com o auxílio de goivas ou pinças cirúrgicas. $O$ término da técnica se dá através do encaixe dos componentes (femoral e acetabular) e realização 
de movimentos do membro para verificar possíveis falhas de implantação da prótese cirúrgica.

\section{ARTROPLASTIA DE QUADRIL}

Como ainda é insipiente a literatura sobre artroplastia de quadril canina, neste capítulo, torna-se necessária a apresentação de uma revisão sobre artroplastias de quadril em humanos (total e de recapeamento) destacando as próteses cirúrgicas existentes, técnica cirúrgica de recapeamento e instrumental cirúrgico utilizado. Em contraste, é discutido o que acontece na medicina veterinária em relação à técnica de artroplastia de recapeamento em quadril de cães nos mesmos aspectos.

\subsection{Artroplastia total de quadril em humanos}

Em humanos, os candidatos a artroplastia de quadril são classificados de acordo com o consenso do National Institutes of Health (NIH), publicado em 1995, e são indicados aqueles que apresentam dor persistente em qualquer que seja o grau (moderada ou severa), sem alívio de dor quando instituído uma terapia conservadora. Segundo o $\mathrm{NIH}$ a artroplastia de quadril é contra-indicada para pacientes que apresentam infecções ativas, sistêmica ou local ou qualquer outra condição que possa levar a complicações durante o procedimento cirúrgico ou até mesmo oferecer risco de morte ao paciente. Um dos fatores mais comuns como contra-indicação para artroplastia se destaca a obesidade, em função do risco de falhas mecânicas nestes pacientes mais pesados (MATOS, 2006).

O sucesso da artroplastia de quadril só é considerado em cinco anos após a cirurgia e como este prazo é teoricamente longo, este sucesso dependerá das técnicas cirúrgicas, experiência do cirurgião e seleção do implante. Por outro lado, a artroplastia total de quadril tem demonstrado sucesso e longevidade dos implantes no período de dez ou mais anos (SCHULZ, 2000).

Futuramente, a artroplastia realizada em articulações de animais debilitados, provavelmente acompanhará a ortopedia humana devido aos estudos focados em melhorias na compatibilidade, longevidade e na função fisiológica dos implantes, bem como na utilização de técnicas minimamente invasivas, instrumentais cirúrgicos adequados e seguros 
e opções biológicas da artroplastia. Dentre as opções biológicas, podem ser citados os implantes autógenos, alógenos e xenógenos, bem como estratégias para a engenharia de tecidos para a reparação primária, substituição e regeneração dos tecidos articulares. A artroplastia biológica tem vantagens teóricas em relação à compatibilidade, longevidade, função fisiológica e, como tal, pode fornecer a capacidade de aperfeiçoamento temporário na forma e função da articulação, quando comparados com implantes sintéticos que se deterioram com o tempo. Na medicina veterinária as técnicas de artroplastia biológica já estão em desenvolvimento. A cirurgia veterinária tem uma vantagem, pois possibilita que as técnicas artroplásticas primeiramente sejam aplicadas em animais e, com isto, é possível que se consiga a posterior colocação em humanos. Com base no potencial de sucesso da artroplastia total e parcial de quadril utilizando metodologias sintéticas e biológicas que proporcionam opções viáveis para reforçar a qualidade e duração da vida, tornando como, por exemplo, a artroplastia em cães muito promissoras, vislumbrando-se de forma otimista a sua aplicabilidade e segurança em humanos (COOK; SCHOLAR, 2007).

\subsection{Cirurgias de Revisão}

As cirurgias de revisão de artroplastias totais de quadril tem se tornado cada vez mais freqüente em humanos devido ao aumento da expectativa de vida da população e também à disseminação dos procedimentos da artroplastia primária. As complicações relacionadas sofrem a mesma tendência (FERRADOSA et al., 2004).

\subsubsection{Primeira cirurgia de revisão}

Na maioria das vezes, as indicações de cirurgia de revisão são resultantes de falhas técnicas na primeira cirurgia e estão freqüentemente relacionadas com a cimentação imperfeita e com eventual mal posicionamento dos componentes. Nas artroplastias não cimentadas, também são cometidos erros equivalentes, principalmente na escolha dos componentes com dimensões inadequadas e com o possível contato deficiente das áreas de revestimento do osso endosteal (AMSTUTZ et al., 1988; BRIEN et al., 1990; CARVALHO et al., 1993; WYSSA et al., 1995). Muitos outros fatores também podem ser indicativos de revisão. A cirurgia de revisão para o tratamento do afrouxamento de implante total do quadril é considerada um dos mais difíceis e ingratos procedimentos em ortopedia. $\mathrm{O}$ afrouxamento mecânico de um ou dos dois componentes podem ser resultantes dos micro-movimentos em 
conseqüência das forças que atuam durante a deambulação (EATON; CAPELLO, 1983; ELIAS et al., 1990). Os fatores mais prováveis que podem favorecer o afrouxamento de um implante de quadril são a obesidade, o nível elevado de atividade física, as sobrecargas excessivas resultantes de quedas e de outros traumatismos, força inadequada de fixação, falhas de crescimento ósseo, falhas na cimentação, perda óssea devido à idade bem como fatores biológicos tais como o afrouxamento por infecção comprovada, instabilidade dos componentes ou luxações repetidas, pseudo-artrose do trocânter maior, calcificação ectópica volumosa com bloqueio de movimentos com dor, dor incapacitante de origem desconhecida e osteólises intensas com deslocamento de componentes. A partir dessas observações, surgiram novos conceitos com o objetivo de reduzir as causas responsáveis pela soltura precoce dos componentes de um implante de quadril. Tais conceitos abrangem diversas áreas como novas técnicas cirúrgicas, dimensões e formato dos componentes, técnicas de cimentação, posicionamento dos componentes, tipo e qualidade do material de implante, instrumental cirúrgico adequado e compatibilidade (ALBUQUERQUE; VIDAL, 1996).

As artroplastias totais do quadril cimentadas apresentam grande problema quando existe a necessidade de revisão. Esse problema torna-se ainda maior quando esses implantes cimentados são novamente utilizados em cirurgias de revisão, pois a cada nova falência do implante acarreta uma cirurgia mais difícil e perigosa devido à alteração da arquitetura femoral e a inevitável perda óssea, resultando em taxas de afrouxamento drasticamente altas. Nos últimos anos, a utilização de implantes totais não cimentados tem sido popularizada buscando obter uma fixação biológica dos componentes e dispensando o uso do cimento. Sob o ponto de vista biológico, é consenso geral que a eliminação do cimento é o primeiro passo na redução da perda óssea. Sob o ponto de vista mecânico, entretanto, é mais difícil obter um firme contato sem a utilização do cimento, que preenche os vazios e as irregularidades que possam existir (RONDINELLI et al., 1993).

A cirurgia de revisão da artroplastia de quadril sempre causa um novo trauma para o paciente e, no Brasil, representa um custo extra para o Sistema Único de Saúde (SUS) e para a sociedade que conseqüentemente acaba arcando com as despesas destas operações. Como citados anteriormente, diversos fatores podem desencadear as falhas ocorridas nos implantes, como por exemplo, a seleção inadequada do material, erros de projeto, falhas na produção e na colocação do implante, falhas de reparação do osso (relacionadas à saúde do paciente) ou ainda pela combinação desses fatores (KLEIN; FREDEL; WENDHAUSEN, 2001). Nos países desenvolvidos existe uma legislação adequada sobre o assunto, além de agências fiscalizadoras e institutos de certificação e normas técnicas específicas, como por exemplo, a ASTM (American Society for Testing Materials) e a ISO (International Organization for Standardization) que objetiva a orientação 
de vários procedimentos inerentes a ciências dos materiais (produção e caracterização) e dos protocolos médicos (retirada, notificação e análise dos implantes que falharam). As normas internacionais recomendam que durante a cirurgia de recolocação, a equipe médica deve fotografar o local antes e após a retirada do implante; obter amostras para exames microbiológicos e histológicos; retirar cuidadosamente o implante preservando as superfícies danificadas e de fratura; identificar todos os componentes e promover a esterilização das peças. Recomenda-se ainda, que esses componentes sejam enviados para os ensaios de conformidade do material, análise dimensional e exame fractográfico da superfície (em caso de fratura). Atualmente a legislação nos EUA sobre falhas de implantes está muito rigorosa com os fabricantes. As falhas em dispositivos médicos devem ser relatadas imediatamente ao FDA (Food and Drug Administration, Departament of Health and Human Services). Os fabricantes destes produtos médicos são considerados responsáveis legais por seus produtos e são obrigados a pagar indenizações aos pacientes lesados. Porém, no Brasil na legislação sanitária atual não há normas que tornem compulsórios os procedimentos de notificação e de investigação dos casos de falhas de implantes cirúrgicos. Comparando-se aos países desenvolvidos, muito pouco é dito na legislação brasileira que regulamente a comercialização de implantes cirúrgicos, o que torna quase inviável um estudo estatístico ou de impacto técnico-econômico nos gastos públicos. Há uma carência de versões nacionais de algumas normas importantes, como por exemplo, documentos que tratam das especificações de ligas usadas em implantes bem como os procedimentos de retirada e análise de falha de implantes cirúrgicos fabricados em metal, cerâmica e polímeros (AZEVEDO; HIPPERT, 2002). Portanto, o trabalho de normatização é um requisito fundamental para a melhoria da qualidade dos produtos utilizados no Brasil.

Segundo Biderman (2011) a segurança das próteses metálicas de quadril está sendo questionada por instituições como a Associação Britânica de Ortopedia e a própria FDA, ambas que regulamentam os produtos de saúde nos EUA e, estudos indicam que essas próteses disponíveis comercialmente, soltam uma quantidade de resíduos metálicos potencialmente prejudiciais à saúde e que estas partículas soltas pelo desgaste do material, podem causar efeitos locais e sistêmicos podendo afetar todo o organismo. Nos Estados Unidos, a FDA pediu para que todos os fabricantes de prótese metálicas apresentem mais estudos sobre a segurança dos implantes ao longo do tempo.

É importante salientar que muitas dessas técnicas promovem em última análise um círculo vicioso, que culmina com o aumento dos defeitos ósseos, tornando as revisões subseqüentes um grande desafio (CABRAL et al., 2006). As cirurgias de revisão, além de mais difíceis, necessitam de estrutura hospitalar e material tão especializado, que em muitos casos transformam este tipo de cirurgia inviável para alguns centros médicos (CARVALHO, 1996; HIPPERT et al, 2002). 


\subsubsection{Segunda cirurgia de revisão}

A segunda cirurgia de revisão de implantes de quadril tem mostrado resultados insatisfatórios. Os resultados variam de acordo com a indicação (ALBUQUERQUE; VIDAL, 1996). Até a presente data, a segunda cirurgia de revisão tem sido pouco relatada, já que os resultados preliminares da primeira cirurgia de revisão têm levantado questões cujas respostas ainda estão ausentes na literatura. Além disso, na literatura não há descrição de dados mostrando se a indicação de cirurgia de revisão é a primeira cirurgia de revisão ou a segunda cirurgia de revisão. Na presente revisão bibliográfica foram encontradas cirurgias de revisão desde 1990 até 2005. Podem ser encontrados na literatura diversos tipos de revisão de cirurgia de quadril como, por exemplo: afrouxamento, enxerto ósseo, troca de prótese não cimentada por prótese cimentada, osteólise, retirada do cimento do canal femoral por osteotomia lateral, avaliação objetiva pelo método de Merle D' Aubigné e Postel, avaliação clínica e radiográfica de pacientes com artroplastia total de quadril com prótese cimentada, revisões das taças acetabulares, acompanhamento de dados clínicos e radiográficos com uso de enxerto homólogo e observação da osteointegração do enxerto liofilizado do ponto de vista radiográfico, conforme mostra a Tabela 3.1.

Tabela 3.1- Tipos de cirurgias de revisão encontradas na literatura.

\begin{tabular}{|c|c|c|}
\hline Autor & Metodologia & Conclusão \\
\hline $\begin{array}{l}\text { Elias et al., } \\
\text { 1990. }\end{array}$ & $\begin{array}{l}\text { Analisaram a ocorrência } \\
\text { afrouxamento de } \\
\text { artroplastias de quadril, utilizando-se } \\
10 \text { próteses de Müller e } 75 \text { de } \\
\text { Charnley. }\end{array}$ & $\begin{array}{l}\text { Concluiu-se que a prótese de } \\
\text { Müller apresentou maior propensão } \\
\text { ao afrouxamento do que as de } \\
\text { Charnley e relacionaram o } \\
\text { afrouxamento ao erro da técnica. }\end{array}$ \\
\hline $\begin{array}{l}\text { Rondinelli et al., } \\
1993 .\end{array}$ & $\begin{array}{l}\text { Apresentaram } 36 \text { casos de revisão de } \\
\text { prótese de quadril utilizando enxerto } \\
\text { ósseo proveniente de banco de } \\
\text { dados. }\end{array}$ & $\begin{array}{l}\text { Segundo esses autores, a } \\
\text { importância de um planejamento } \\
\text { cirúrgico adequado bem como a } \\
\text { realização do diagnóstico e } \\
\text { tratamento cirúrgico precoce, com } \\
\text { o intuito de realizar procedimentos } \\
\text { cirúrgicos menos complexos } \\
\text { aumenta a chance de um melhor } \\
\text { resultado para as cirurgias de } \\
\text { quadril. }\end{array}$ \\
\hline $\begin{array}{l}\text { Roos; Camisa } \\
\text { Jr, } 1994 .\end{array}$ & $\begin{array}{l}\text { Estudaram os resultados de } 40 \\
\text { pacientes de cirurgia de revisão de } \\
\text { prótese de quadril cimentada, em que } \\
\text { foi efetuada a reconstrução do } \\
\text { acetábulo utilizando-se blocos de } \\
\text { osso homólogo de banco fixados com } \\
\text { parafusos. }\end{array}$ & $\begin{array}{l}\text { Baseado neste estudo, os autores } \\
\text { concluíram que este é um método } \\
\text { seguro e eficaz no tratamento de } \\
\text { afrouxamento asséptico. }\end{array}$ \\
\hline
\end{tabular}


Tabela 3.1- Tipos de cirurgias de revisão encontradas na literatura (Continuação).

\begin{tabular}{|c|c|c|}
\hline $\begin{array}{l}\text { Turíbio et al., } \\
1994 .\end{array}$ & $\begin{array}{l}\text { Paciente teve o quadril com artrite } \\
\text { reconstruído com implante não } \\
\text { cimentado do tipo Harris-Galante, } \\
\text { apresentando soltura do } \\
\text { componente acetabular. }\end{array}$ & $\begin{array}{l}\text { A prótese apresentava-se deformada } \\
\text { e totalmente desligada do osso que a } \\
\text { continha; porém o estojo ósseo foi } \\
\text { capaz de receber uma nova prótese } \\
\text { cimentada do tipo Müller. }\end{array}$ \\
\hline $\begin{array}{l}\text { Aristídes et al., } \\
1996 .\end{array}$ & $\begin{array}{l}\text { No período de } 1986 \text { a } 1992 \text {, foram } \\
\text { avaliados } 135 \text { quadris submetidos } \\
\text { à artroplastia total com } \\
\text { componente acetabular não } \\
\text { cimentado do tipo Harris-Galante. }\end{array}$ & $\begin{array}{l}\text { O desgaste do polietileno foi superior } \\
\text { às médias descritas na literatura para } \\
\text { artroplastias cimentadas, sendo o } \\
\text { maior desgaste em cabeça femoral de } \\
28 \mathrm{~mm} \text { de diâmetro. }\end{array}$ \\
\hline $\begin{array}{l}\text { Carvalho et al., } \\
1996 .\end{array}$ & $\begin{array}{l}\text { Os autores destacam o método de } \\
\text { osteotomia lateral e proximal do } \\
\text { fêmur em } 26 \text { casos para a retirada } \\
\text { do cimento do canal femoral em } \\
\text { cirurgias de revisão. }\end{array}$ & $\begin{array}{l}\text { Todos os casos foram considerados } \\
\text { de boa evolução, diminuindo o tempo } \\
\text { de cirurgia, assim como as } \\
\text { complicações inerentes à retirada do } \\
\text { cimento no canal femoral. Dois casos } \\
\text { de pseudoartrose foram relatados } \\
\text { como complicação, porém não } \\
\text { comprometendo o resultado funcional } \\
\text { da artroplastia de revisão. }\end{array}$ \\
\hline $\begin{array}{l}\text { Albuquerque; } \\
\text { Vidal, } 1997 .\end{array}$ & $\begin{array}{l}\text { Realizou-se uma avaliação } \\
\text { retrospectiva em } 53 \text { próteses não- } \\
\text { cimentadas. }\end{array}$ & $\begin{array}{l}\text { As próteses de Galante apresentaram } \\
\text { bons resultados } 39,62 \% \text {; os regulares } \\
26,41 \% \text { e os maus } 33,96 \% \text {. As } \\
\text { próteses de Roy-Camille } 71,3 \% \text { de } \\
\text { bons, } 15,2 \% \text { de regulares e } 13,5 \% \text { de } \\
\text { maus. }\end{array}$ \\
\hline $\begin{array}{l}\text { Freitas et al., } \\
1997 .\end{array}$ & $\begin{array}{l}\text { No período de } 1975 \text { e } 1985 \text { foi } \\
\text { realizada uma reavaliação clínica e } \\
\text { radiológica em } 92 \text { pacientes, } \\
\text { totalizando } 111 \text { casos de } \\
\text { artroplastia total de quadril com } \\
\text { utilização de prótese cimentada de } \\
\text { Charnley. }\end{array}$ & $\begin{array}{l}\text { Um total de } 60 \% \text { das próteses } \\
\text { cimentadas estava estável, sem } \\
\text { sinais clínicos ou radiológicos de } \\
\text { soltura. Encontraram-se evidências } \\
\text { de afrouxamento nos outros } 40 \% \text {, das } \\
\text { quais } 64 \% \text { foram do componente } \\
\text { acetabular, } 23 \% \text { do femoral e } 23 \% \text { em } \\
\text { ambos os componentes. }\end{array}$ \\
\hline
\end{tabular}


Tabela 3.1- Tipos de cirurgias de revisão encontradas na literatura (Continuação).

\begin{tabular}{|c|c|c|}
\hline $\begin{array}{l}\text { Drummond et } \\
\text { al., } 1999 .\end{array}$ & $\begin{array}{l}44 \text { pacientes e } 56 \text { quadris foram } \\
\text { submetidos a revisões de taças } \\
\text { acetabulares e avaliados os casos } \\
\text { de solturas em artroplastias totais } \\
\text { de quadril. Utilizaram-se taças } \\
\text { porosas rosqueadas de titânio } \\
\text { revestidas com hidroxiapatita } \\
\text { inseridas com adição de enxerto } \\
\text { ilíaco autólogo. }\end{array}$ & $\begin{array}{l}\text { Os resultados clínicos foram } \\
\text { satisfatórios em } 50 \text { quadris }(89,3 \%) \text {. } \\
\text { Os seis maus resultados foram devido } \\
\text { à soltura asséptica (cinco casos) e } \\
\text { metalose (um caso), necessitando de } \\
\text { revisão adicional. De acordo com os } \\
\text { autores, as complicações mais } \\
\text { comuns foram à migração de taça e } \\
\text { luxação pós-operatória. }\end{array}$ \\
\hline $\begin{array}{l}\text { Ferradosa } \\
\text { al., } 2004 .\end{array}$ & $\begin{array}{l}\text { Estudaram vários casos baseados } \\
\text { em dados clínicos e radiográficos } \\
\text { dos pacientes submetidos à } \\
\text { revisão de artroplastia do quadril } \\
\text { com uso de enxerto homólogo } \\
\text { (cadáver). }\end{array}$ & $\begin{array}{l}\text { Os autores enfatizam que os } \\
\text { resultados obtidos devem-se ao } \\
\text { conjunto de condições técnicas } \\
\text { alcançadas no hospital (INTO- } \\
\text { Instituto Nacional de Ortopedia e } \\
\text { Traumatologia) e a técnica } \\
\text { apresentada não deve ser utilizada } \\
\text { indiscriminadamente, sendo que este } \\
\text { estudo apresentou uma boa solução } \\
\text { perante os muitos problemas da } \\
\text { ortopedia. }\end{array}$ \\
\hline $\begin{array}{l}\text { Fujiki et al., } \\
2005 .\end{array}$ & $\begin{array}{l}\text { O objetivo deste trabalho foi } \\
\text { mostrar a osteointegração do } \\
\text { enxerto liofilizado homólogo } \\
\text { impactado do ponto de vista } \\
\text { clínico-radiográfico em revisão de } \\
\text { artroplastia total de quadril. Os } \\
\text { autores estudaram oito pacientes } \\
\text { com soltura asséptica e perda de } \\
\text { estoque ósseo. Foram operados } \\
\text { sete componentes acetabulares e } \\
\text { cinco componentes femorais. }\end{array}$ & $\begin{array}{l}\text { Concluiu-se que apesar do pouco } \\
\text { tempo de seguimento ( } 33 \text { meses) e o } \\
\text { pequeno número de casos, o uso do } \\
\text { enxerto liofilizado em cirurgias de } \\
\text { revisão de artroplastia pode ser uma } \\
\text { opção viável. }\end{array}$ \\
\hline
\end{tabular}




\subsubsection{Próteses cirúrgicas de quadril utilizadas na ortopedia humana}

Em determinadas ocasiões, certas partes do corpo humano, podem deixar de exercer suas funções de forma adequada; isto pode ocorrer devido a acidentes, doenças ou desgaste natural com o uso. Em alguns casos o problema pode ser amenizado ou resolvido através do uso de implantes artificiais, com a função de substituir a parte danificada. Existem diversos materiais que podem ser implantados no corpo humano, porém a escolha do material adequado se baseia nas propriedades mecânicas, físicas, químicas e biológicas requeridas para cada caso (MELLO et al., 2003).

As próteses de um modo geral tem a capacidade de devolver a qualidade de vida para os pacientes que sofreram danos músculos-esqueléticos provocados por doenças ou traumas através do restabelecimento da função das articulações. Em associação com novas gerações de materiais e novas concepções de fabricação, ampliaram-se as possibilidades para a construção de implantes e próteses cirúrgicas mais eficientes.

Uma variedade de implantes ortopédicos, parafusos, placas e hastes que substituem, total ou parcialmente, as articulações do corpo humano, como quadril, joelho e ombro, estão disponíveis no mercado. Cada paciente apresenta diferenças na recuperação, mas é possível retomar uma vida normal ou, no mínimo, ter uma qualidade de vida melhor após a realização de substituições de articulações através de próteses ou implantes artificiais. A indicação para o uso de um determinado implante depende da idade do paciente, do tipo de doença, da qualidade do osso, da experiência do cirurgião e do instrumental cirúrgico adequado. Para garantir a integridade dos componentes dos implantes, normalmente são realizados testes de qualidade, que definem a durabilidade dos implantes e asseguram os certificados de qualidade exigidos pelo mercado. O sucesso dos implantes depende do projeto, qualidade da matéria-prima, processo produtivo adequado, correta indicação do cirurgião, planejamento pré-operatório, instrumental cirúrgico adequado, correta implantação do implante e comportamento do paciente condizente ao de um portador de implante. Atualmente, o maior desafio na área de implantes é a prorrogação da vida útil dos implantes (MONTAGNOLI, 2010).

Os implantes ortopédicos podem ser divididos em duas categorias: implantes temporários de fixação de fraturas e implantes permanentes de substituição de partes do esqueleto humano. No implante temporário, espera-se resistência mecânica suficiente para substituir temporariamente o papel desempenhado pelo osso em determinado segmento do aparelho locomotor, aliados a composições que não promovam reações indesejáveis no organismo, até que o osso esteja totalmente restabelecido. Exemplos clássicos de implantes 
temporários que podem ser citados são as placas de fixação para ossos fraturados, os pinos e os parafusos. No implante permanente, ou seja, no caso de substituição de articulações, tem-se um desafio adicional: suportar contínuos movimentos e transmitir carga, que é o caso de próteses de joelho, quadril e cotovelo (CHOHFI et al., 1997; FRAKER; RUFF, 1977).

Devido a doenças degenerativas ou acidentes, algumas partes do corpo humano podem perder total ou parcialmente suas funções. A utilização de novas técnicas de análises clínicas tais como ressonância magnética e tomografia computadorizada auxiliam na identificação das causas que levam à perda das funções. Entretanto, identificar as causas do problema não é suficiente. É preciso que se tome uma ação corretiva que permita a recuperação da função perdida de tal forma que o paciente possa voltar a viver uma vida normal. Porém, muitas vezes o elemento responsável pela perda da função não pode ser recuperado e só resta tentar substituir por um outro artificial (BOSCHI, 1995).

O termo biomaterial pode ser interpretado de duas maneiras distintas; primeiro como materiais biológicos, que podem ser: homólogos (quando originados do próprio indivíduo, como é o caso de pontes de safena), autólogos (quando originados de outras pessoas) ou heterólogos (quando originados de animais e aproveitados em implantes ou cirurgias); e segundo, como materiais sintéticos para implantes cirúrgicos, que se dividem em metálicos (ferrosos e não ferrosos), cerâmicos, poliméricos e compósitos, que vem à substituir a função original e uma parte dos materiais biológicos (GOMIDE, 2005).

Os biomateriais em termos de aplicação em próteses cirúrgicas e implantes, podem oferecer ao paciente um aumento na longevidade e melhora na qualidade de vida. Inicialmente focado no tratamento de situações da vida, o uso de novos materiais tem crescido progressivamente para o uso das mais variadas funções corporais. Eles são empregados para atender as necessidades que o paciente apresente em termos de reabilitação, conforto, conveniência e estética, aceitando-os como parte integrante do tratamento médico. Sendo o "material reconstrutor" do corpo humano, eles têm uma função na reconstituição e preservação do bem estar físico psicológico e social do indivíduo (BURNY et al., 1995).

Os materiais utilizados para implantes e próteses cirúrgicas englobam uma grande quantidade de diferentes produtos, hoje desenvolvidos para numerosas aplicações na medicina em cirurgias, os quais são, por definição, planejados para uso em contato com um organismo vivo. Estes materiais têm exigido um aspecto comum para tais aplicações como certo grau de tolerância desses materiais quanto ao contato com tecidos e órgãos. Como conseqüências disso, estes materiais apresentam definições críticas para cada necessidade, diferenciando-se largamente para cada aplicação em particular. Entretanto, estes materiais apresentam inúmeros problemas relacionados com a estrutura química e 
física do produto, que, em adição tem que apresentar uma boa resistência mecânica, resistência ao meio, entre outros (CHAPIRO, 1995).

O principal objetivo do uso de novos materiais é a restauração de funções dos tecidos e órgãos do corpo humano. Portanto, é importante, quando se trabalha com novos materiais, o entendimento da correlação entre propriedades, funções e estruturas dos materiais biológicos. No estudo dos novos materiais, consideram-se três áreas: materiais biológicos, materiais de implante e a interação do tecido biológico e material do implante (ZAVAGLIA, 1993).

As próteses totais da articulação do quadril é constituída de vários componentes e diferentes métodos de fixação. Os principais componentes de uma artroplastia total de quadril são o acetábulo, a cabeça e a haste femoral, conforme ilustra a Figura 3.1. Existem dois tipos básicos de implantes de quadril: os cimentados e os não cimentados. Os implantes cimentados podem ainda ser divididos em implantes com haste e sem haste (DUCHEYNE, 1982).

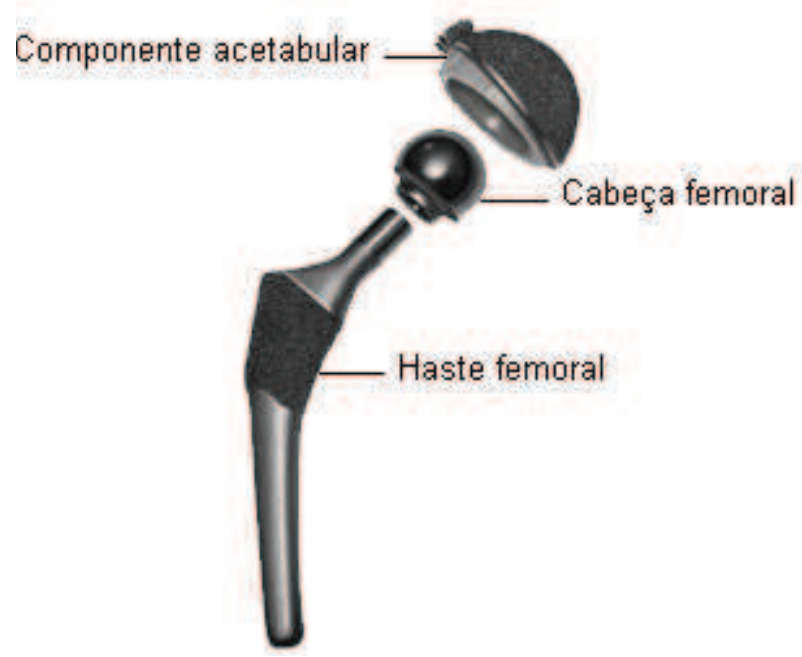

Figura 3.1- Componentes de uma prótese de quadril. [ALVES; BERGMANN; STAINER, 2011].

Ducheyne 1982 apud Wrege 2000 ressalta que o mancal natural do quadril é composto por um acetábulo constituído por osso esponjoso recoberto por uma camada de tecido cortical formando um "sanduíche", envolvendo ossos de pequena massa, com grande momento de inércia e boa resistência ao dobramento.

Devido à complexidade construtiva apresentada, os reparos no mancal do quadril iniciaram-se em 1926 quando Hey-Groves utilizou parafusos de madeira para a fixação de implantes. Muitos materiais naturais como madeira, celulóide, borracha, prata, vidro e marfim foram utilizados nesta primeira fase. No ano de 1931, Smith-Petersen projetou o primeiro sistema de fixação que impedia a rotação da cabeça do fêmur. Thornton no ano de 
1937 fixou uma placa de metal com parafusos para distanciar o pescoço de Smith-Petersen. Em 1939, Smith-Petersen utilizou uma cavidade artificial de vidro, pyrex, baquelita e vitallium sobre a cabeça femoral criando uma nova superfície para a união danificada. Os irmãos Judet da França, de forma semelhante, utilizaram implantes de metilmetacrilato, conforme ilustra a Figura 3.2 (PARK, 1990; KURTZ et al., 1999).

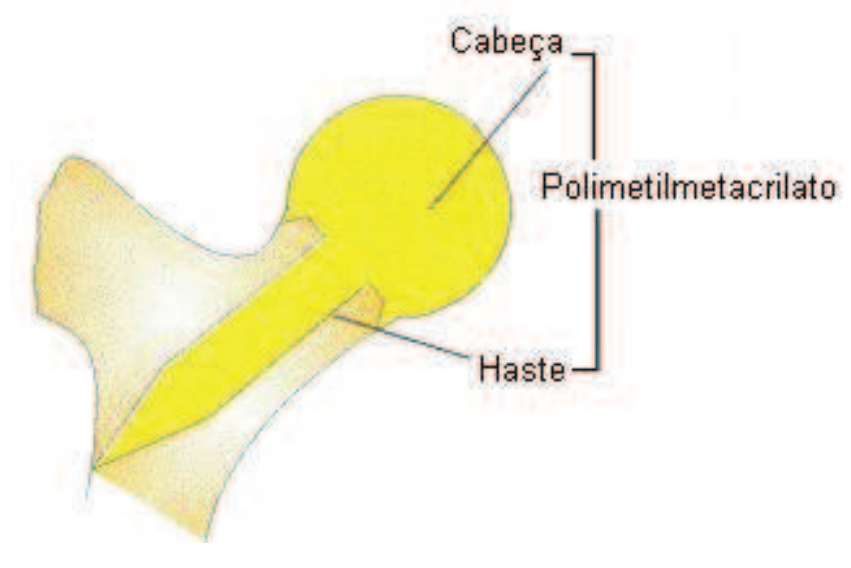

Figura 3.2- Prótese de quadril dos irmãos JUDET.

[WREGE, 2000; PARK, 1990].

A partir de 1968, Boutin, Griss, Judet, Morscher, Ring, Mittelmeier, Salzer e Lord desenvolveram novos projetos de implantes onde era considerada a ancoragem direta do implante por travamento mecânico através de crescimento ósseo. Judet e Lord utilizaram uma camada de material poroso para facilitar a ancoragem do implante aos tecidos. A Figura 3.3 ilustra os implantes desenvolvidos por Lord e Judet (DUCHEYNE, 1982).

A partir dos anos 70, foram introduzidos os implantes com esfera de cerâmica, onde inicialmente apresentaram uma grande porcentagem de falhas entre 7 a 13\%. Em 1980, com a inclusão da norma ISO 6474, que especifica o material cerâmico de alumina, observou-se uma diminuição nos índices de falhas entre 0 e 2,4\% (PICONI; MACCAURO, 1999).
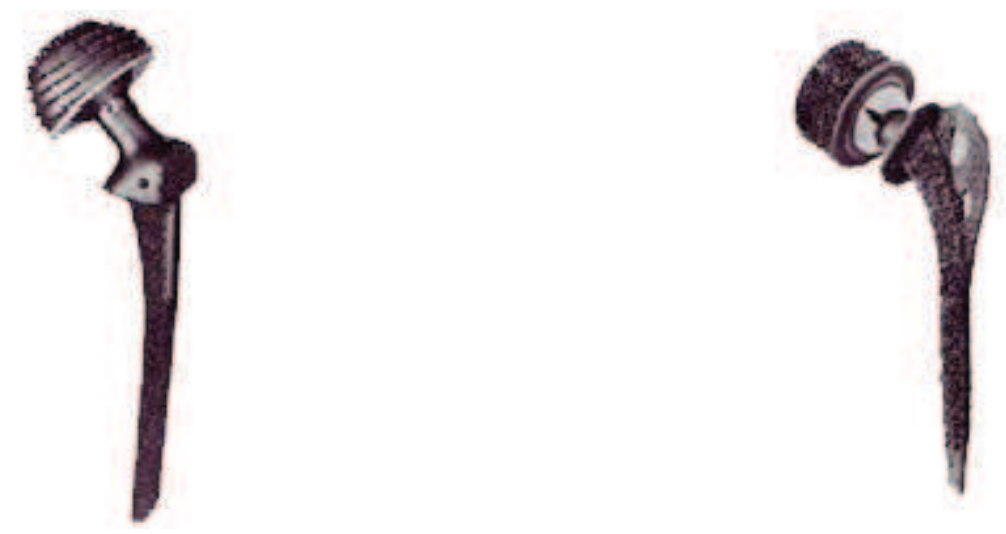

Figura 3.3- Prótese total de quadril não cimentada. [HISTORY..., 2011]. 
Os implantes com haste são ainda hoje, os mais utilizados com uma grande variedade de tipos de acetábulo. Em projetos de implantes, alguns itens são considerados como durabilidade, tolerância do paciente aos resíduos dos materiais desgastados, atrito moderado com a finalidade de não prejudicar a fixação do implante e mobilidade. A Figura 3.4 ilustra algumas dimensões geométricas que normalmente são consideradas no projeto de um implante de quadril (WILLIANS, 1982). Nessa figura, as esferas (A) possuem diâmetros variando entre $22,0 \mathrm{~mm}$ a $56,0 \mathrm{~mm}$. A escolha do diâmetro está relacionada com a possibilidade de maior ou menor mobilidade, espessura da parede acetabular e as diferenças no torque aplicado no implante (DUCHEYNE, 1982; WILLMANN, 1996). comprimento do pescoço (B) é um parâmetro importante no projeto de implantes. Um pescoço curto poderá limitar o campo de mobilidade e um pescoço longo, aumenta o carregamento no implante e o torque aplicado na região do calcar (C) podendo ocasionar falhas na união devido a problemas associados à interface tecido duro/implante. O pescoço do implante deverá possuir uma inclinação entre $135^{\circ}$ a $145^{\circ}$. A haste deverá possuir um diâmetro mínimo de 12,0 mm em função dos esforços atuantes. Em relação ao calcar (C), podem ser encontradas duas possibilidades: implantes com apoio e sem apoio. $O$ comprimento da haste (D) intramedular pode variar de $120,0 \mathrm{~mm}$ a $180,0 \mathrm{~mm}$. A rigidez, o formato e o material são alguns dos parâmetros importantes no projeto da haste. Os formatos em "T" e em "H" tem-se mostrado mais estáveis (DUCHEYNE, 1982 apud WREGE, 2000).

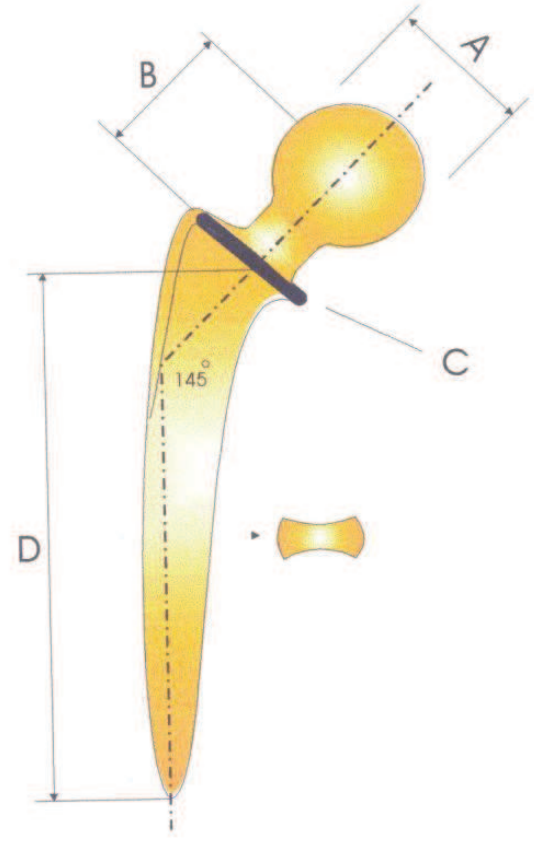

Figura 3.4 Componentes de artroplastia total de quadril. [WREGE, 2000]. 
Os materiais comercialmente utilizados na fabricação dos implantes de quadril do tipo bola e soquete são as ligas metálicas na fabricação de hastes, UHWMPE (polietileno de ultra-alto peso molecular) na fabricação do acetábulo e metal ou cerâmica na fabricação de esferas (OONISHI et al., 1998). Para a fabricação de esferas tem-se utilizados materiais como o cobalto, o cromo, a alumina e a zircônia (HENCH, 1993; SAIKKO, 1993; WILLMANN, 1996).

De acordo com a concepção, quase todos os implantes totais de quadril disponíveis no mercado são do tipo modular. Essa concepção utiliza um sistema auto-travante constituído por um cone, segundo os padrões da norma F1636-95 da ASTM, que realiza a fixação da esfera à haste intramedular conforme ilustra a Figura 3.5 do projeto de implante modular apresentado por ZAVAGLIA (1993).

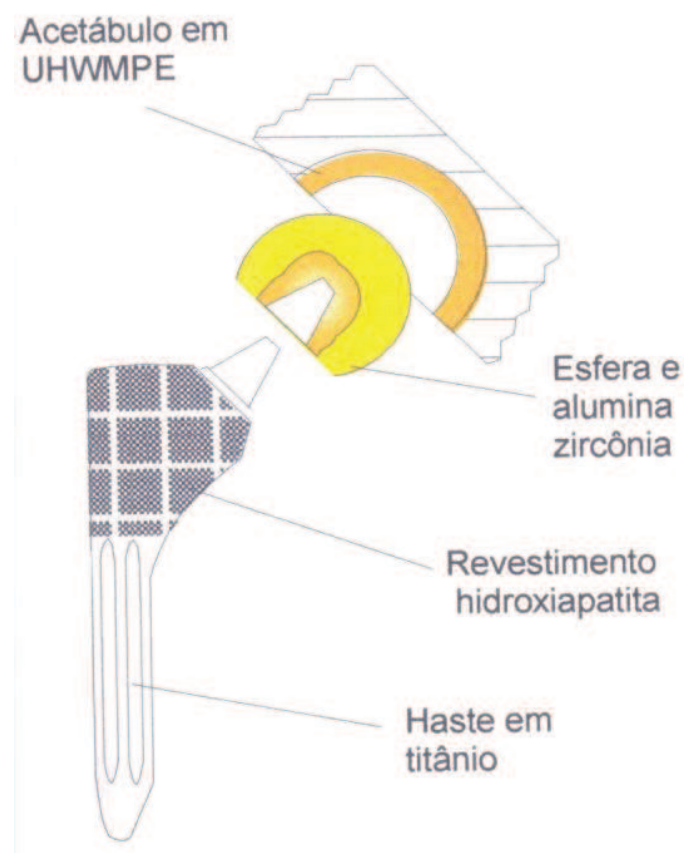

Figura 3.5 Prótese de projeto modular [ZAVAGLIA, 1993].

Conforme Piconi et al., (1999) a utilização deste sistema apresenta algumas desvantagens para o mancal, causando um estado complexo de tensões. Devido à configuração geométrica, a tensão de compressão aplicada na prótese gera na esfera tensões tangencial e de flexão. A tensão tangencial atua na área superior do cone.

Para a seleção de um material durante a fase de projeto de implantes e próteses cirúrgicas é necessário o envolvimento de diversas áreas de conhecimento. Os materiais como metais, cerâmicas e compósitos, bem como a quantidade de materiais competitivos 
disponíveis no mercado tem aumentado consideravelmente, por exemplo, o uso de novas exigências relativamente ao desempenho, em especial, a relação rejeição $x$ compatibilidade e a previsão de eventuais falhas por desestabilidade micro-estrutural, degradação, oxidação e outras.

A grande preocupação hoje em foco está, relacionada com a qualidade e segurança sanitária dos produtos: eles devem ser fabricados com matéria-prima (polietileno, titânio, cromo-cobalto, aço inox, cerâmica, entre outros) de extrema pureza, pois se destinam a ficar por muitos anos dentro do corpo do paciente. Isto requer a segurança máxima, seja em relação ao material com que são produzidos, seja no que se refere à tecnologia do projeto, desenho e fabricação (AGÊNCIA NACIONAL DE VIGILÂNCIA SANITÁRIA, 2004).

Os implantes destinados às aplicações ortopédicas devem exibir um conjunto de propriedades das quais destacam-se a compatibilidade, a resistência mecânica, a resistência à fadiga, a resistência à corrosão e ao desgaste. A área de produtos ortopédicos ainda carece de uma melhora regulamentação em nosso País. Os primeiros passos neste sentido estão sendo dados pela Agência Nacional de Vigilância Sanitária (ANVISA) do Ministério da Saúde, através de Regulamento Técnico da Qualidade, recentemente colocado em consulta pública. Esse regulamento estabelece os critérios de qualidade de implantes metálicos ortopédicos fabricados em aço inoxidável para fins de fixação de fraturas (osteossíntese). Já as próteses totais de quadril deverão merecer tratamento idêntico pela ANVISA. Estudos conduzidos nos Estados Unidos na década de 90 revelam que cerca de $10 \%$ dos dispositivos para osteossíntese removidos de pacientes encontravam-se fora de especificações fixadas pelas normas ASTM (American Society for Testing and Materials) então vigentes. No Brasil, os dados que se referem à qualidade das próteses totais de quadril são praticamente inexistentes, sendo maciçamente adquiridas pela rede hospitalar pública e privadas. (CAVALCANTI et al, 2002).

Segundo Biderman (2011), a agência americana (FDA) responsável pela regulamentação de próteses cirúrgicas de quadril nos EUA, estão exigindo melhores estudos sobre a segurança das próteses cirúrgicas, pois devido ao fato destes componentes protéticos serem de metais, por sua vez, liberam partículas metálicas na corrente sanguínea podendo causar destruição óssea e até mesmo problemas renais, salienta ainda que as pessoas que possuem estas próteses cirúrgicas apresentam valores 20 vezes mais altos do que os considerados normais. Já no Brasil, a ANVISA irá acompanhar o histórico e a evolução dos pacientes submetidos à artroplastia de quadril.

$\mathrm{Na}$ ortopedia, os avanços são notáveis. Próteses de joelho e de quadril duram mais de dez anos e substituem o osso com perfeição. O paciente deixa o hospital em dois dias; há cinco anos, a internação durava uma semana e a diminuição do tamanho do corte dos implantes de quadril que diminuiu de 15,0 para 8,0 centímetros. (VASCONCELOS, 2004). 
Ainda hoje, permanece uma carência de trabalhos publicados que comprovem alguns aspectos importantes no projeto de próteses cirúrgicas de quadril, tais como o melhor afilamento (conicidade) das hastes para artroplastias totais de quadril. As próteses podem ser definidas como componentes projetados e fabricados para serem introduzidos no corpo humano a fim de reabilitar ao máximo a qualidade de vida do paciente. As próteses têm sido aplicadas com sucesso em intervenções cirúrgicas para substituição de estruturas ósseas danificadas e articulações para o alívio da dor devido a doenças como osteoporose, traumas e fraturas graves, em especial as do joelho e quadril.

A era moderna de substituições totais de articulações iniciou nos últimos anos da década de cinqüenta com o trabalho pioneiro de John Charnley, que estabeleceu a estrutura fundamental da substituição total de articulação de quadril com um componente metálico mantendo contato sob carregamento contra um componente de polietileno fixado ao osso com cimento acrílico. O uso desse polímero acrílico para fixação permitiu uma estabilidade permanente de implantes metálicos. Este conceito de fixação rígida inicial foi um passo essencial para aperfeiçoar a viabilidade de próteses de quadril intramedulares e substituições totais de joelho.

Desde então, as próteses de quadril e joelho mantêm suas estruturas fundamentais. Embora a grande maioria das articulações artificiais implantadas tenha sobrevivido por mais de dez anos, ainda existe a necessidade de aperfeiçoamento. A taxa de revisão é considerada alta para os padrões atuais, com cada vez mais próteses implantadas em pacientes cada vez mais jovens e ativos. Considerando que o paciente busca o alívio de seu sofrimento e a reabilitação de seu estilo de vida, as taxas de revisão devido às falhas em sistemas implantados devem ser reduzidas. As cirurgias de revisão são sacrificantes e diminuem paulatinamente a qualidade do sistema, visto que o osso é quase sempre reajustado para receber a nova prótese. Muitos estudos têm sido realizados para melhorar este panorama, com a finalidade de elevar a vida útil das próteses. Dentre as razões para os implementos, pode-se citar o crescente número de articulações artificiais que estão sendo implantados todos os anos em todo o mundo, o alto custo envolvido, e uma forte e contínua demanda para a evolução tecnológica de implantes ortopédicos que durem mais do que vinte anos no corpo humano. No Brasil, a maior parte dos casos de traumas é coberta pelo Sistema Único de Saúde (SUS) e nota-se a importância da iniciativa do setor industrial brasileiro em fabricar produtos nacionais confiáveis, instrumental cirúrgico adequado, seguro e eficiente, diminuindo a dependência dos produtos importados e principalmente visando à diminuição de importação.

No decorrer dos anos, os implantes foram sofrendo alterações de projeto e conseqüentemente melhorias. A Tabela 3.1 ilustra vários implantes ou próteses cirúrgicas de quadril que foram evoluindo de acordo com a necessidade; alguns tipos destes implantes 
são utilizados até hoje. Cada um destes implantes apresenta as suas vantagens e desvantagens.

Tabela 3.2- Tipos de próteses de quadril.

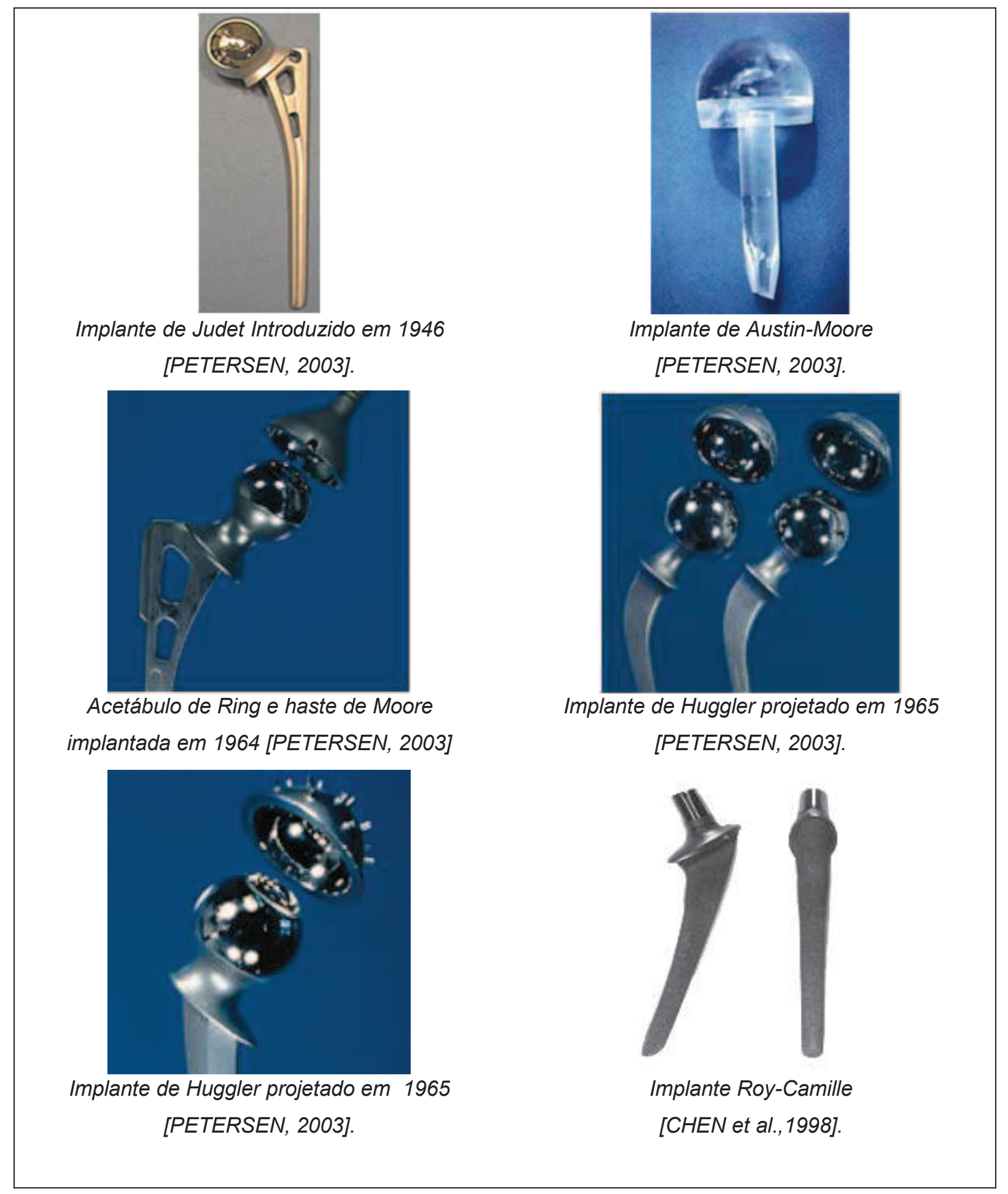


Tabela 3.2- Tipos de próteses de quadril (Continuação).

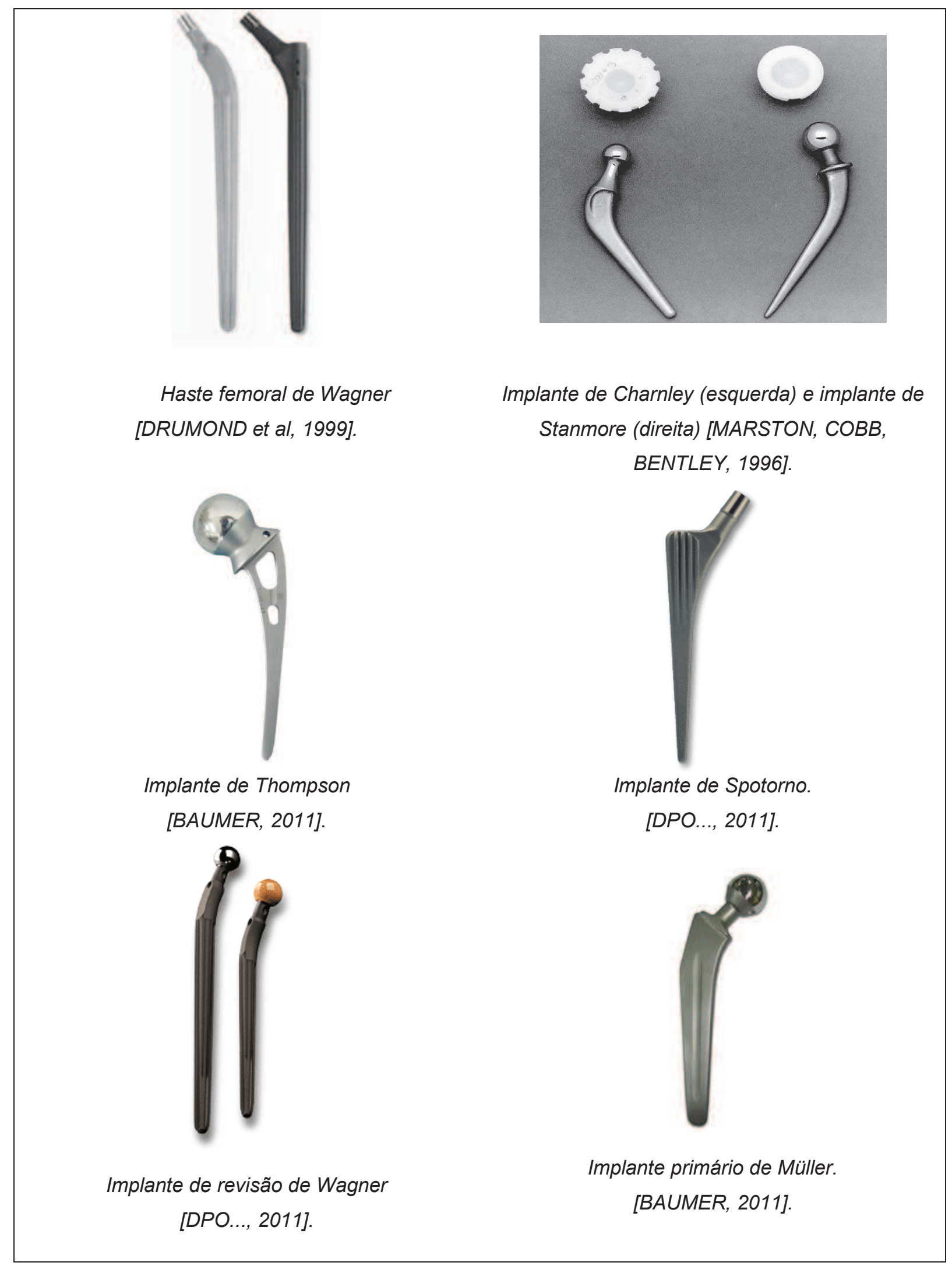


Tabela 3.2- Tipos de próteses de quadril (Continuação).

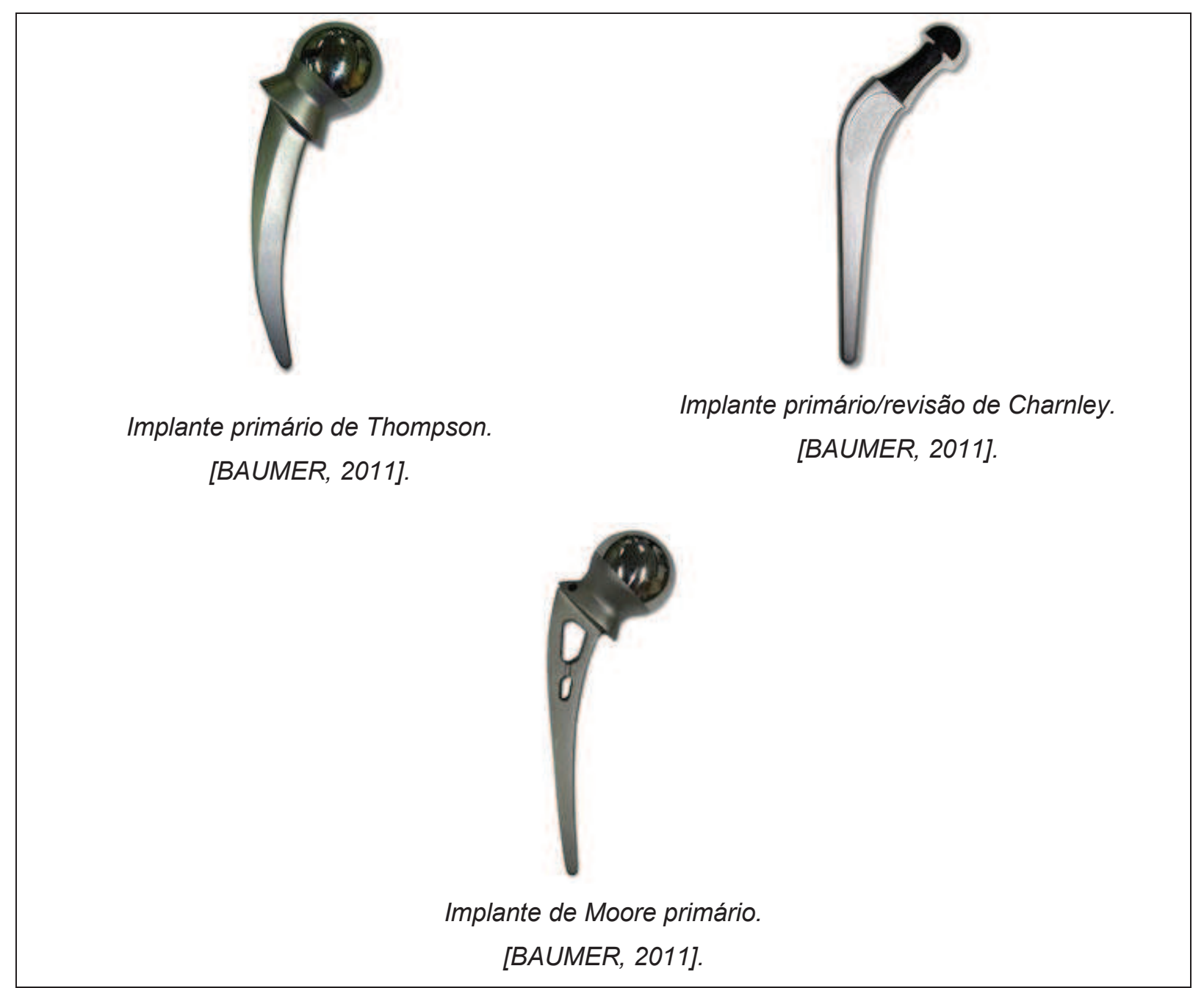

\subsubsection{Recapeamento de quadril em humanos}

Nos últimos anos, o recapeamento de quadril tem sido considerado como uma alternativa viável à substituição convencional do quadril (ADAMS; QUIGLEY, 2005).

A cirurgia de artroplastia convencional do quadril exige que o cirurgião remova completamente a cabeça femoral. Em contraste, na tentativa do recapeamento de quadril em preservar a maior parte da cabeça femoral, ocorre somente à substituição da superfície da articulação. Esta técnica preserva o canal femoral intacto, tornando uma eventual revisão de cirurgia muito mais fácil e segura. Além disso, o recapeamento possui uma menor taxa de deslocamento e permite uma maior variedade de movimentos ativos do que a substituição convencional de quadril. Por essas e outras razões, o recapeamento de quadril representa uma proposta particularmente atraente para pacientes jovens e ativos (CUTTS e CARTER, 2006). 
Amstutz et al., (1998) definem o recapeamento como um conceito atrativo devido à preservação do estoque do osso femoral proximal, a transferência da tensão (stress) ao fêmur proximal, grande diâmetro da articulação, além de oferecer estabilidade inerente e ampla variedade de movimento.

O recapeamento de quadril tem sido utilizado progressivamente em pacientes jovens e ativos. No entanto, deve ser ressaltado que até o presente momento não existem dados clínicos suficientes que comprovem os resultados satisfatórios esperados, sendo que o período de utilização desse implante ainda é pequeno, mas tudo indica que esse tipo de artroplastia de quadril será a primeira opção para um paciente jovem, pois além de permitir o seu rápido retorno às atividades físicas anteriores à cirurgia, preservam uma valiosa quantidade de osso para uma eventual revisão posterior (McMINN et al., 1996; AMSTUTZ et al., 2004; BEAULÉ; et al., 2004; LAGE; FAGA, 2003).

A idéia de preservar o estoque ósseo nas artroplastias de quadril não é um conceito novo. A taça (acetábulo) de Smith-Petersen foi implantada pela primeira vez em 1923, porém ela era confeccionada de vidro e era muito frágil. Posteriormente, o pyrex passou a ser utilizado por ser um vidro mais resistente, no entanto, ainda não era satisfatório. A partir de 1938, Cooke passou a utilizar taças de metal (vitallium) e em 1948 foram apresentados resultados dos seus 500 casos de hemi-atroplastias de recapeamento de quadril. A hemiartroplastia sem nenhum meio de fixação estável à cabeça femoral perdurou por muitos anos. O primeiro recapeamento de artroplastia total foi desenvolvido por Charnley nos anos 50, usando um mancal de teflon, conforme ilustra a Figura 3.6. Esse implante foi associado a uma elevada falha precoce que Charnley atribuiu à necrose da cabeça femoral. Subseqüentemente, Charnley (1950) reconheceu as características pobres do desgaste do teflon quando foi usado como mancal em uma substituição total de quadril (GRIGORIS et al., 2005).

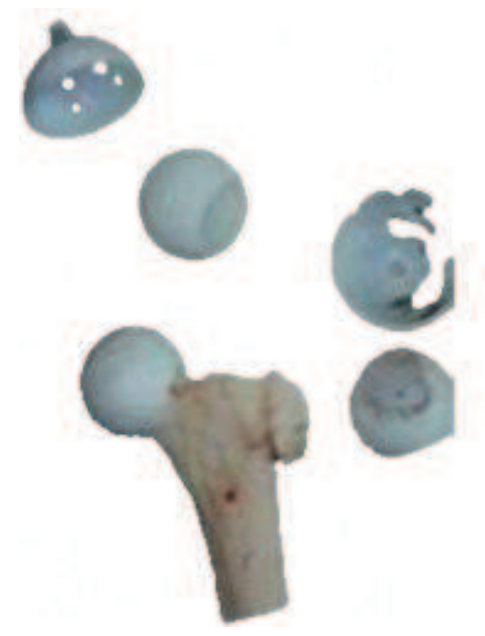

Figura 3.6- Recapeamento de teflon com desgaste. [CATALANI, 2011]. 
Nos anos 60, tentou-se desenvolver um recapeamento de quadril utilizando uma articulação de poliuretano que foi associada a um desgaste catastrófico. Mais tarde foram substituídos por uma articulação de polietileno, mas os resultados não foram animadores devido à soltura precoce e desgaste prematuro do polietileno. A Figura 3.7 ilustra este implante de quadril (TOWNLEY 1982 apud GRIGORIS et al., 2005).

No ano de 1967, utilizou-se pela primeira vez a articulação de metal como recapeamento. Apesar dos excelentes resultados clínicos, abandonou-se o uso da articulação de metal em favor da articulação de polietileno. A Figura 3.8 ilustra a extremidade direita de um recapeamento com cimento.

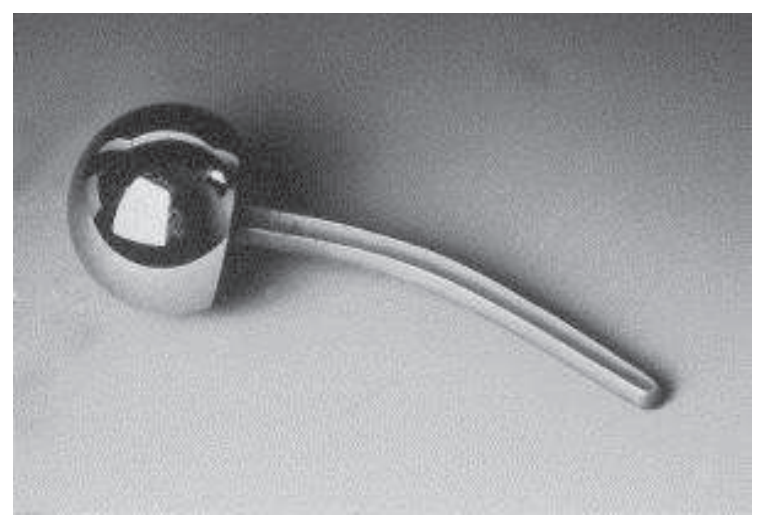

Figura 3.7- Componente femoral para hemiresurfacing de artroplastia femoral,

[GRIGORIS et al, 2005].

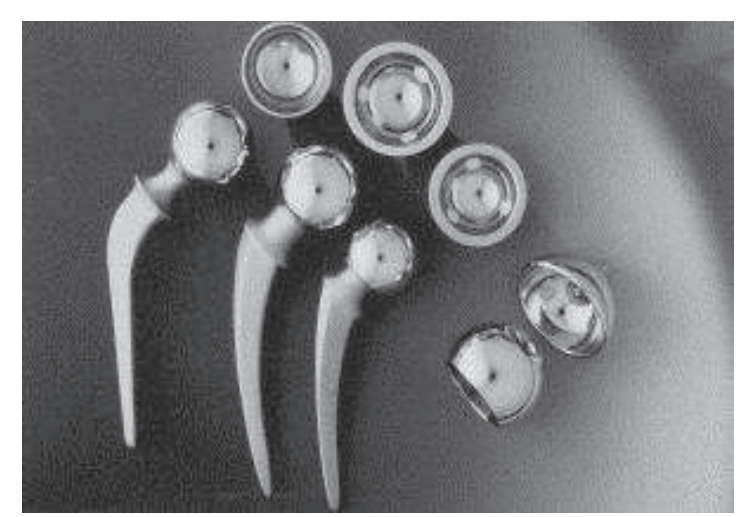

Figura 3.8- Próteses de quadril de metal. [GRIGORIS et al., 2005].

\footnotetext{
${ }^{1}$ TOWLEY, C.O. (1982) Hemi and total articular replacement artrhoplast of the hip with the fixed femoral cup. Orthopedic Clinics of North America, v.13, n.4, p.869-894.
} 
Gerald (1978) introduziu o recapeamento bipolar de metal em 1970. O sistema consistia de um acetábulo Luck inserido dentro de um acetábulo Aufranc Vitallium (Howmedica Inc, Rutherford, NJ), que permitia o movimento entre o implante, o acetábulo e a cavidade óssea. Em 1972, o acetábulo Aufranc foi substituído por um acetábulo de polietileno numa tentativa de diminuir o atrito entre os dois implantes, entretanto, a superfície convexa do componente do polietileno que se articulou com o acetábulo desgastou rapidamente, e essa combinação foi abandonada em 1975 a favor de uma combinação bipolar de metal com um enchimento de polietileno (GRIGORIS et al., 2005).

Furuya e Tsuchiya (1978), no Japão, desenvolveram um recapeamento usando um componente acetabular de aço inoxidável com um componente femoral de polietileno de alta densidade (HDP) e fixado com cimento e, subseqüentemente, mudaram a combinação do material, usando um componente femoral de metal ou cerâmica. Nishio e colaboradores no ano de 1972 combinaram o componente acetabular Urist com seu próprio componente femoral feito de vitallium; em 1975, o componente acetabular foi substituído por um soquete alinhado de polietileno sem cimento. Tanaka em 1974 introduziu um sistema híbrido com um soquete excêntrico cimentado e cabeça de metal (GRIGORIS et al., 2005).

Em 1971 foram implantados recapeamentos de quadril cimentado usando componentes acetabulares de polietileno e componentes femorais de metal desenvolvidos por Paltrinieri e Trentani (1971) na Itália, que apresentava uma parede fina toda de polietileno e uma taça acetabular conforme pode ser observada na Figura 3.9. Freeman (1978) por sua vez, usou componente femoral e um componente acetabular de metal, que resultou em um rápido desgaste da superfície convexa. No mesmo ano na Alemanha, Wagner (1974) introduziu um recapeamento de quadril que foi utilizado extensamente na Europa, conforme ilustra a Figura 3.10 (ROBERTS et al., 2005).

O componente acetabular tinha uma espessura de somente $4,0 \mathrm{~mm}$, os materiais utilizados eram de cobalto-cromo ( $\mathrm{Co}-\mathrm{Cr}$ ) e componente femoral, de cerâmica, mas, a preparação da cabeça ainda estava indefinida. No começo de 1976 em Viena, Salzer utilizou o recapeamento de cerâmica (alumina) sem cimento, mas foi logo abandonado devido às altas taxas de afrouxamento (ROBERTS et al., 2005; GRIGORIS et al., 2005). 


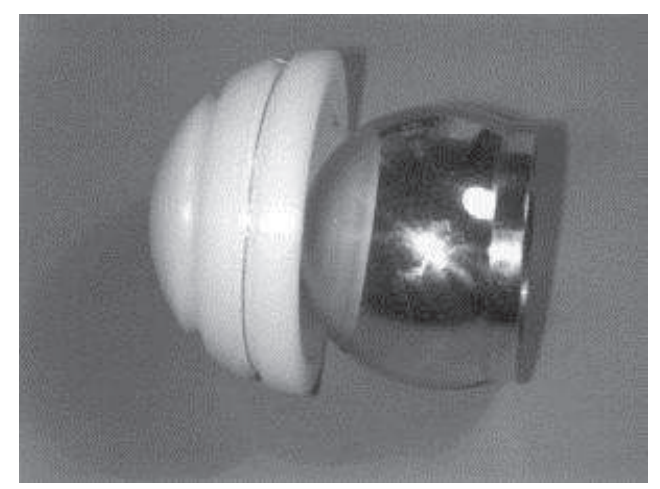

Figura 3.9- Recapeamento de quadril cimentado. [GRIGORIS et al., 2005].

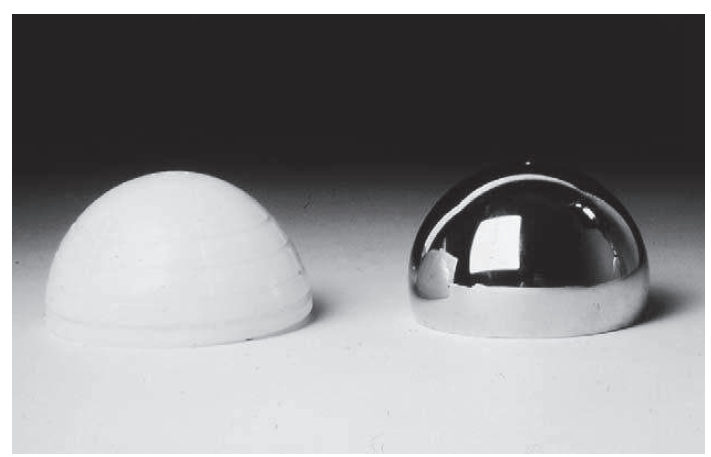

Figura 3.10- Sistema de recapeamento cimentado de metal-polietileno. [ROBERTS et al., 2005].

Nos Estados Unidos, em 1973, Eicher e Capello desenvolveram um recapeamento de quadril cimentado usando um metal como componente femoral e polietileno como componente acetabular; o componente acetabular foi reforçado com revestimento de metal em 1982. Amstutz em 1975 introduziu o THARIES (Substituição total articular do quadril usando escudos excêntricos internos) na Universidade da Califórnia - Los Angeles. O implante era cimentado e consistia de um componente femoral de Co-Cr e componente acetabular todo de polietileno, conforme ilustra a Figura 3.11. Ambos os componentes eram excêntricos, com espessura máxima do polietileno de 3,5 a 5,5 mm. Em 1982 foi introduzido um componente acetabular de metal recoberto de plasma pulverizado de polietileno para o uso com cimento. 


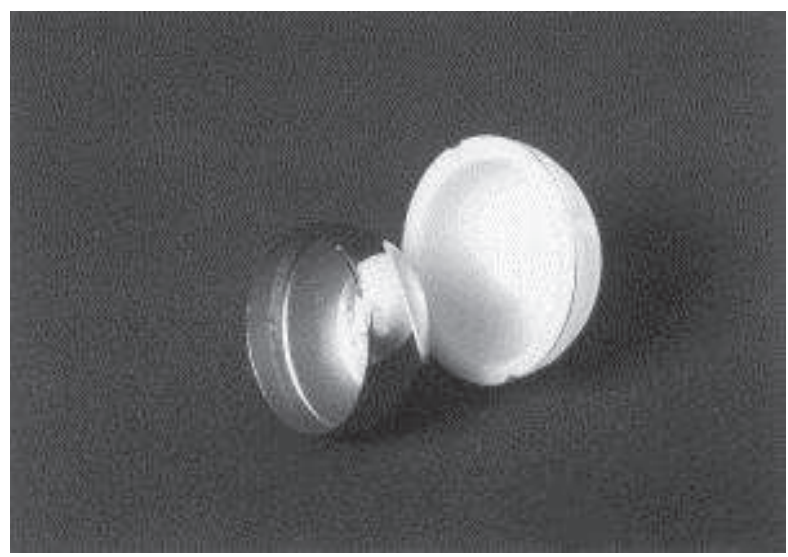

Figura 3.11- Prótese para artroplastia de recapeamento cimentada. [GRIGORIS et al., 2005].

No ano de 1983, Amstutz et al, (1977); Amstutz et al., (1978) implantou sem cimento a primeira artroplastia de recapeamento com componente femoral de Ti-6Al-4V, com forro acetabular de polietileno de ultra-alto peso molecular (UHMWPE) e revestimento protetor poroso de malha de titânio puro. Inicialmente, os soquetes eram hemisféricos e fixados com parafusos, e mais tarde foi desenvolvido o primeiro soquete chanfrado de cilindro com ajuste por interferência, como pode ser observada na Figura 3.12.

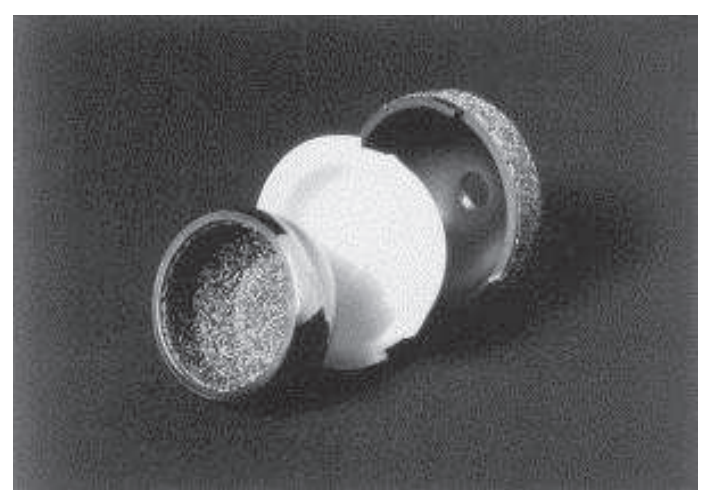

Figura 3.12- Sistema de substituição de superfície porosa. [GRIGORIS et al., 2005].

Em 1988, Amstutz desenvolveu um outro sistema poroso revestido, sem cimento, com componente femoral de Co-Cr, um forro modular e um componente acetabular hemisférico de Ti-Al-4V. No ano de 1989, Buechel e Pappas introduziram um sistema de recapeamento sem cimento com um componente acetabular modular e um componente femoral de liga de nitreto de titânio e um componente femoral de liga de titânio revestido de cerâmica (GRIGORIS et al., 2005). Muito provavelmente, esses foram os maiores avanços na artroplastia de recapeamento de quadril na década de 80. 


\subsubsection{Modelos de Implantes de Recapeamento}

Atualmente, há cerca de dez principais fabricantes de implantes metálicos de recapeamento no mercado. Os modelos de implantes de recapeamento ilustrados e seus respectivos centros médicos como estão ilustrados na Figura 3.13. Nessa figura encontramse os seguintes implantes de recapeamento:

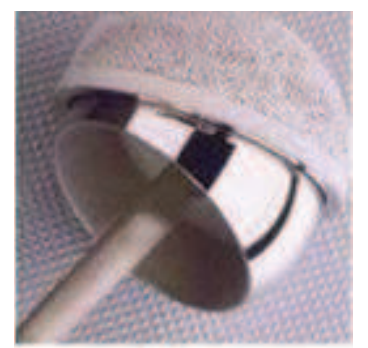

(a)

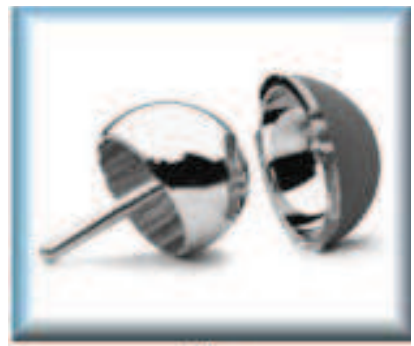

(d)

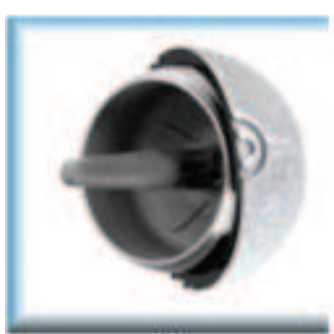

(g)

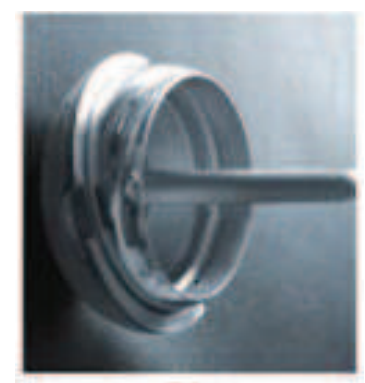

(b)

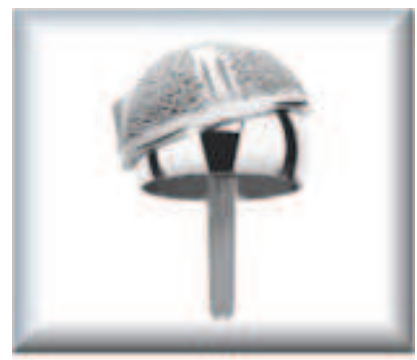

(e)

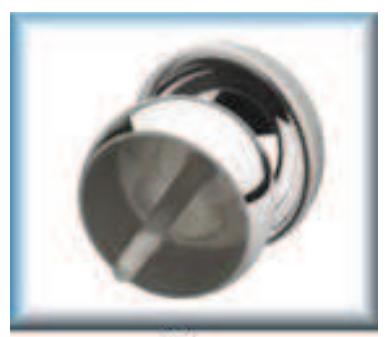

(h)

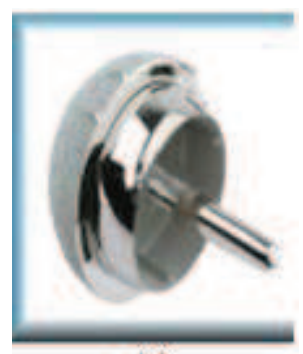

(c)

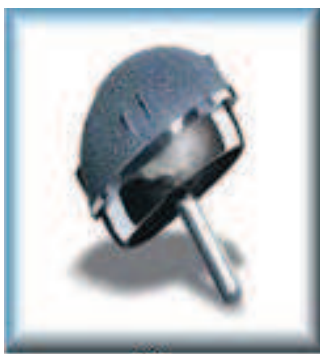

(f)

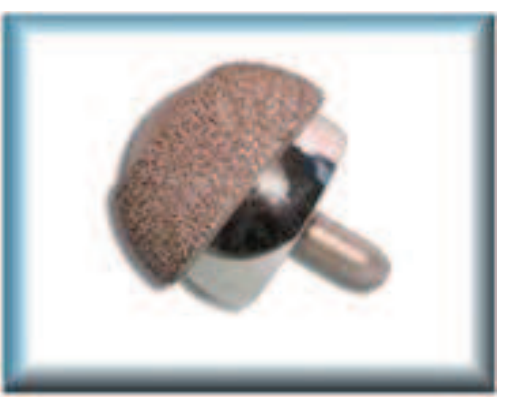

(i)

Figura 3.13- Principais implantes metálicos de recapeamento existentes no mercado. [HIP..., 2011a].

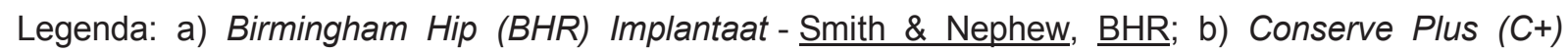
Implantaat - Wright Medical Technology; c) Cormet 2000 (C2K) Implantaat - Corin Medical, Ltd.; d) Durom Implantaat - Zimmer; e) ICON Implantaat - International Orthopaedics; f) ReCap Implantaat Biomet Inc.; g) ADEPT Implantaat - Finsbury Orthopaedics Ltd.; h) ASR Implantaat - J\&J DePuy; I) System BS/PROFI - ESKA Implants. 


\subsubsection{Reconstrução de quadril - Histórico}

Petersen (2003) em sua tese de doutorado pesquisou o desenvolvimento da artroplastia de quadril. Ela relata que provavelmente, o princípio original da intervenção da artroplastia foi para inserir um espaçador mecânico entre superfícies ósseas cruas para prevenir a refusão e manter o movimento e estabilidade. Vários métodos foram utilizados desde então tais como o de Carnochan (1840) de Nova York que colocou um bloco de madeira na extremidade da articulação do quadril. Métodos biológicos e externos foram também utilizados ao longo do tempo como a pele, fáscia, músculo, bexiga de porco e lâmina de ouro. Em todos eles, no entanto, a maioria das cirurgias reuniu-se com resultados imprevisíveis e dolorosos.

Em 1933, Marius Smith-Petersen introduziu o conceito de um molde de artroplastia. Ele foi inspirado na reação gerada através de um pedaço de vidro nas costas de um operário. O desenho original foi em forma de sino e feito de vidro. A princípio, era para estimular a regeneração da cartilagem em ambos os lados do vidro moldado na articulação. A Figura 3. 14 ilustra esse molde.

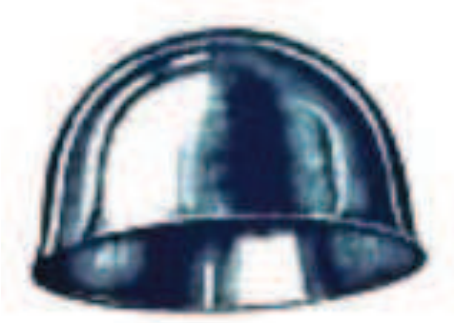

Figura 3.14- Molde de artroplastia em forma de sino. [SMITH - PETERSEN*,

(1978 Apud LAGE; FAGA, 2003)].

* SMITH - PETERSEN, M.N. (1978). Evolution of mould arthroplasty of hip joint. Clinical of Orthopaedics, v. 134, p.5-11.

Smith-Petersen (1978) pretendia remover o vidro após a restauração da cartilagem, porém, o vidro revelou-se demasiadamente frágil e eventualmente foi fraturado, gerando a necessidade de se usar outros materiais, tais como o viscalóide, um derivado de celulóide 
(1925), o pyrex (1933), a baquelite (1939), e mais tarde nesse mesmo ano, o vitallium, uma liga de cobalto-cromo, que demonstrou ser inerte e durável.

O modelo original do acetábulo para implantes de quadril tinha uma extremidade rasa em torno de suas bordas para proporcionar estabilidade. No entanto essa extremidade rasa favorecia o aparecimento de tecido fibroso que limitava o movimento das partes do implante. Esse projeto foi modificado por Otto E. Aufranc (1937), um assistente de SmithPetersen, que desenvolveu um acetábulo hemisférico chamado True-Arc, onde removeu a extremidade rasa e acrescentou contornos interiores e exteriores congruentes. Aufranc, que trabalhou com técnicas cirúrgicas meticulosas, relata com uma taxa de $82 \%$ de sucesso em uma série de 1000 artroplastias (acetábulo). Todavia, a maioria dos cirurgiões da época, só foi capaz de atingir uma taxa de $50 \%$ de sucesso. Esse projeto foi um marco na cirurgia de quadril e dos seus princípios para prenunciar sua posterior evolução. Foi nessa época que se observou que a cavidade acetabular na artroplastia do acetábulo iria ficar ocasionalmente presa no acetábulo e permitiria o movimento somente entre a cabeça femoral e o acetábulo. Isso levou ao desenvolvimento de uma cavidade a ser fixada ao acetábulo, que também ficou conhecido como artroplastia hip-socket. Apesar dos bons resultados obtidos por Gaenslen (1952), McBride (1955) e Urist (1957), este procedimento não se tornou popular.

A haste femoral para a artroplastia de quadril foi desenvolvida em 1890 por Gluck que utilizou uma articulação de marfim e acabou descobrindo que os seres humanos poderiam tolerar durante algum tempo grandes objetos estranhos no corpo. Já Delbet, no ano de 1919, usou uma cabeça femoral de borracha para tratar fraturas de colo do fêmur. Em 1926, Groves utilizou pregos de marfim para substituir a superfície articular da cabeça femoral. Mais tarde, tornou-se um modelo utilizado em curto prazo, resultando em prótese femoral. Bohlman e T. Austin Moore em 1939, colaboraram com a fabricação e implantação de uma prótese da cabeça femoral de vitallium para um paciente com um tumor gigante. Esta prótese funcionou bem e mais tarde influenciou o desenvolvimento da prótese da cabeça femoral. Provavelmente, a prótese mais popular na época foi a desenvolvida por F.R. Thompson e T. Austin Moore na década de 1950. A prótese de Austin-Moore continha perfurações para o auto-travamento que mais tarde tornou-se a base para a fixação biológica. Essa prótese foi muito utilizada por McKee-Farrar (1979) em artroplastia total de quadril. Os méritos de ambos os projetos são evidentes para corroborar a sua atual utilização.

A eficácia da artroplastia femoral somente é relativa aos problemas concernentes ao lado acetabular da articulação, particularmente quando combinados com um eventual fracasso da artroplastia do tipo hip socket. Isso levou ao desenvolvimento da primeira artroplastia total do quadril por Phillip Wiles em 1938, em Londres, conforme mostra a Figura 3.15. Era uma articulação de quadril total feita de aço inoxidável que falhou devido ao 
afrouxamento. O início da II Grande Guerra Mundial teve um grande efeito no progresso da artroplastia total do quadril devido ao conhecimento adquirido com as lutas da Primeira Guerra Mundial, pois ajudou no tratamento das vítimas da Segunda Guerra Mundial. Nesta, houve menos amputações executadas, menos gangrena, melhores meios de fixação das fraturas, sem esquecer da importância da penicilina, cujos efeitos foram descobertos por Alexander Flemming em 1928.

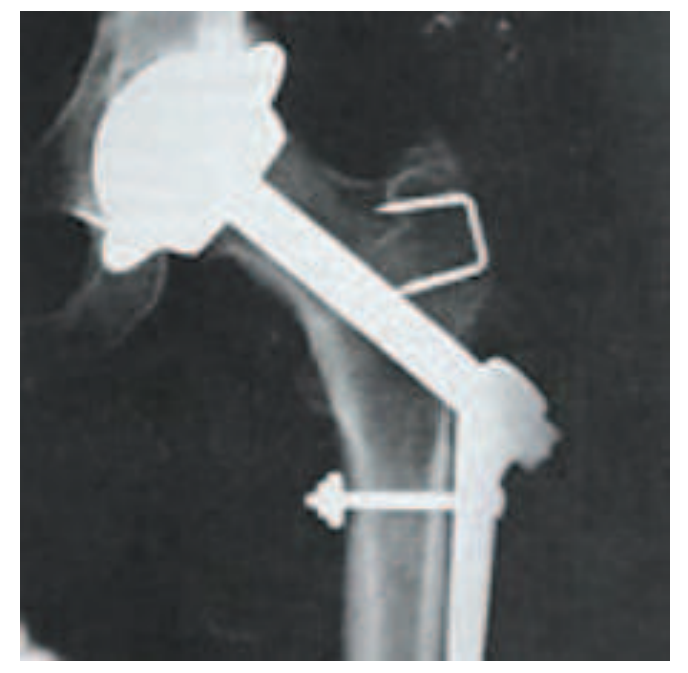

Figura 3.15- Artroplastia total de quadril de aço inoxidável. [CATALANI, 2011].

Os alemães precisavam de medidas rápidas para recolocar os seus soldados em condições de lutar e desenvolveram vários procedimentos de fixação de fraturas durante este período, além, da contribuição dos americanos como Willis Campbell que era o principal defensor da artroplastia de interposição naquela época. Campbell usou um transplante autógeno livre do músculo fáscia lata, dobrado sobre si mesmo. Sendo assim, Campbell não buscava restabelecer a anatomia original, mas sim restabelecer a função, além de executar a enxertia óssea utilizando um enxerto ósseo total encavilhado e fixado com parafusos ósseos para pseudoartrose. Em 1942, Albert J. Schein, de Nova lorque, publicou em um artigo que estabeleceu a doença de Gaucher como uma específica e não muito rara causa de doença de quadril. Isto foi muito importante, pois muitos casos estavam sendo mal diagnosticados como Doença de Perthés (que é uma obstrução transitória da circulação da cabeça femoral (GUARNIERO et al., 2005). Ainda em 1942, Austin T. Moore executou e noticiou a primeira substituição de quadril com uma prótese metálica. Pela primeira vez, ele tinha substituído a porção superior inteira do fêmur com uma prótese de vitallium. Apresentava uma cabeça redonda, laçadas para inserção de músculos e uma extremidade inferior que deslizava para o interior da diáfise fixando-se a ela. Com o passar 
dos anos, melhorou o desenho da prótese e a técnica cirúrgica. Como conseqüência, há um tipo de prótese chamada Austin-Moore que é utilizada atualmente (BRAKOULIAS, 2010).

No ano de 1950, Sven Kiar introduziu o cimento acrílico para a medicina. Em função disso, a articulação total de quadril de McKee-Farrar que chegou em 1951 e suas versões posteriores incluíram modificações que permitiram o aumento da amplitude de movimento com uma haste fixada com cimento acrílico. Em 1951, no Norwich Hospital, McKee e Farrar implantaram em três pacientes um sistema de articulação, cujo acetábulo era parafusado na pelve e o componente femoral constituído de uma esfera era ligado a uma haste que atravessava a cortical lateral do fêmur para ser acoplada a uma placa aí parafusada. Duas das próteses eram feitas em aço inoxidável e a terceira em cromo-cobalto; esta última durava três anos (McKEE; WATSON-FARRAR 1966). Em 1953, após contato com a prótese de Thompson, McKee adotou o mesmo desenho para o componente femoral e, em 1960, por sugestão de Watson-Farrar, ele tornou a cabeça femoral esférica. Essas próteses, ainda com o acetábulo parafusado, foram usadas entre 1956 e 1960 em 40 cirurgias de quadris, com $57 \%$ de bons resultados após sete anos e alguns ainda funcionando com 12 a 16 anos de pós-operatório (AMSTUTZ ; GRIGORIS, 1996).

Em 1954, McBride começou a aplicar sua prótese, cujo componente acetabular era dotado de um colar para ser adaptado no rebordo do acetábulo. Em 1970, Shorbe relatou os resultados de 86 artroplastias do quadril, com $67 \%$ de bons resultados, embora com seguimento curto. Em outra série, Lunceford, neste mesmo ano, referiu 20 casos com seguimento de até cinco anos com resultados bastante favoráveis. O cimento como elemento de fixação das próteses começou a ser empregado por McKee em 1961 e numa primeira série de 100 pacientes operados até 1964 ocorreram 35 falhas e revisões. O colo alargado do componente femoral levava à colisão com o acetábulo, provocando a soltura. A melhoria dos componentes com estreitamento do colo femoral e a redução do diâmetro do acetábulo levaram a $84 \%$ de bons resultados após três a sete anos de evolução. Ainda assim, essas próteses apresentavam baixa qualidade de fabricação em relação à esfericidade e ao acabamento das superfícies de carga. As próteses de McKee eram fabricadas com uma folga de 0,15 mm pela empresa Down Bros. Ltd., na Grã Bretanha, que mais tarde produziria também as próteses de RING. No entanto, outra empresa copiou a prótese de McKee, produzindo-a com folga nula, chamada de microfit. Essas próteses travavam precocemente, causando afrouxamento e contribuindo para seu abandono em favor das próteses metal/polietileno. No entanto, Huggler desenvolveu na Suíça, em 1965, uma prótese metal/metal (cromo-cobalto), inicialmente com folga zero e depois com folga de 0,2 mm. Em 1968, McKee notou que o ajuste perfeito da cabeça e do acetábulo levava o contato localizado na região equatorial da cabeça e a um maior desgaste. Após essa data, as próteses foram confeccionadas com a cabeça ligeiramente menor do que o componente 
acetabular, provocando contato na região polar e reduzindo o desgaste (AMSTUTZ e GRIGORIS, 1996). Os resultados precoces das artroplastias feitas com a prótese de McKeeFarrar pareciam favoráveis, porém, com o decorrer da evolução, apenas cerca de $50 \%$ poderiam ser considerados como bons ou excelentes (AUGUST et al., 1986; CHAPCHAL et al., 1970; FREEMAN; McKEE-FARRAR, 1970; TILBERG, 1988).

Sir John Charnley (1960) pai da moderna artroplastia total do quadril, desenvolveu o conceito de artroplastia de quadril de baixo atrito. Suas idéias foram desenvolvidas após os resultados promissores de seu trabalho com a lubrificação da articulação em animais e constatou-se que a cartilagem precisava de um substituto necessário, permitindo que as articulações artificiais funcionassem com baixo nível de atrito como ocorre na natureza. Sua primeira tentativa para a solução do problema foi à utilização de teflon na superfície do fêmur e no componente acetabular. O rápido fracasso dessa solução levou ao desenvolvimento de uma nova concepção: de uma cabeça femoral de pequeno diâmetro anexada a uma haste fixada com acrílico, articulando-se com um acetábulo de teflon. Esta nova concepção falhou rapidamente devido ao mau uso e as características promovidas pela reação inflamatória. Charnley analisou as falhas e abandonou o uso do teflon em 1961. Isto levou ao desenvolvimento de um soquete que foi feito de polietileno de ultra alto peso molecular (UHMWPE), com propriedades de resistência ao desgaste que foram 500 a 1000 vezes superiores que as do teflon.

Müller (1970) desenvolveu uma articulação total de quadril, utilizando uma esfera de $32,0 \mathrm{~mm}$, que foi moldada com uma haste em formato de banana que permitia uma fácil inserção no fêmur sem ter que realizar uma osteotomia transtrocânteriana.

Em Exeter, ROBIN LING e colaboradores desde 1970, deram início ao desenvolvimento de uma haste femoral, enquanto que nos Estados Unidos, Otto E. Aufranc e Roderick H. Turner introduziram o popular sistema de quadril chamado Aufranc Turner. A substituição total da articulação do quadril tornou-se ainda mais comum após a aprovação de polimetilmetacrilato (PMMA) em 1971 pela Food and Drug Administration (FDA), nos Estados Unidos. Usando técnicas de cimentação como foi descrita por Charnley em 1979, os afrouxamentos assépticos constituíram a modalidade mais comum de falhas de cirurgias de quadril durante esta década. Com o desenvolvimento da concepção do projeto assistido por computador (CAD) e as super ligas, os sistemas modernos para a articulação total do quadril, utilizaram hastes mais anatômicas com maiores deslocamentos e ângulos de cabeça e colo mais anatômicos. Durante este tempo, Harris (1986) desenvolveu o conceito de acetábulo de metal com um forro removível visando uma antecipação dos problemas de desgaste futuros. Esse projeto futuramente seria incorporado à cavidade com cimento.

A articulação do quadril de lowa foi desenhada por Crowninshield e colaboradores (1980) com o objetivo de reduzir a tensão no manto proximal do cimento. O novo conceito 
estava relacionado com a produção de uma tensão compressiva, em vez de uma tensão proximal ao redor do manto proximal de cimento. Esta idéia de uma secção transversal de cunha afunilada de flanges de cimento laterais teria efeitos futuros em sistemas como o Spectron, ATS, Precision e Charnley Cobra stems conforme ilustra a Figura 3.16 (CROWNINSHIELD et al., 1980 apud PETERSEN, 2003).
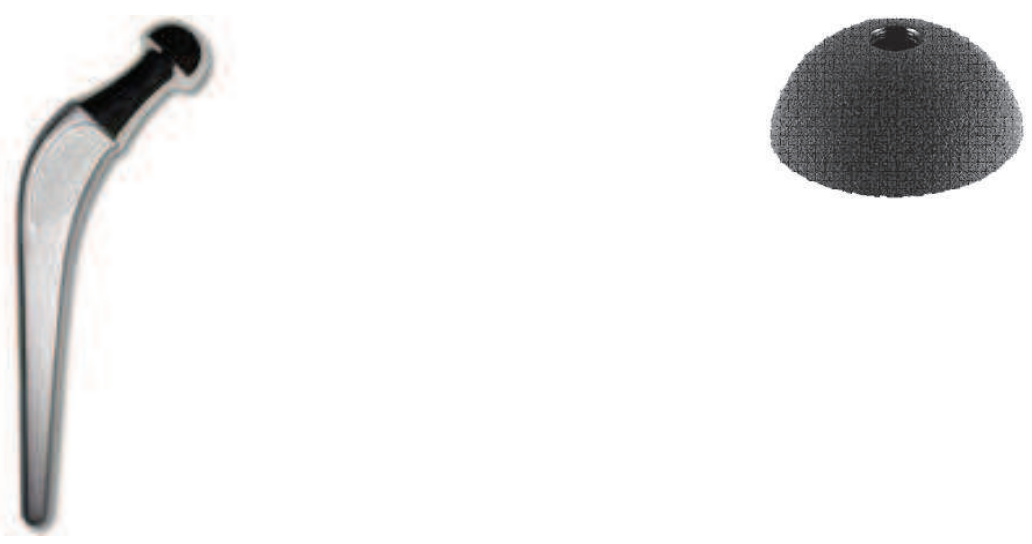

Figura 3.16- A seção transversal cônica e flanges concebidos para produzir compressão no manto do cimento introduzido por CHARNLEY em 1975. A Figura à direita mostra componente acetabular revestido com hidroxiapatita. [PETERSEN, 2003].

No final dos anos 1970 e início da década 1980, não havia interesse na "dupla-taça" ou superfície de substituição de artroplastia (que consistia de um componente femoral de metal que se encaixava no fêmur e um componente acetabular de polietileno que revestia o acetábulo). Todas as versões da dupla taça partilharam de um defeito similar intrínseco: a parede fina de polietileno produzia rapidamente grandes quantidades de resíduos de desgaste, afrouxamento precoce da haste e osteólise. Por estas razões, este método foi abandonado pela maioria dos ortopedistas.

O fracasso precoce do implante relativamente a sua haste levou as pessoas a acreditarem que o cimento usado na fixação era o elo fraco. Esta opinião fomenta duas ideologias: a crença na melhoria da qualidade e das técnicas de cimentação, e a crença em alterar a fixação da haste ao fêmur sem a utilização do cimento (PETERSEN, 2003).

A fixação sem cimento havia sido utilizada na Europa por muitos anos. Nos Estados Unidos, no entanto, a atenção foi dada aos implantes de metal com revestimento poroso, que levou ao desenvolvimento da AML (Anatomic Medullary Locking), APC (Pourous-Coated Monatomic), e HGP (Harris-Galante-Porous) para as substituições totais de quadril. As Figuras 3.17 e 3.18 ilustram os implantes AML e HGP, respectivamente. Mais recentemente (1977), tem havido interesse em revestimentos de HAp (hidroxiapatita) na América do Norte e Europa, o que incentivou uma resposta mais rápida para estabilizar técnicas de fixação da haste. 


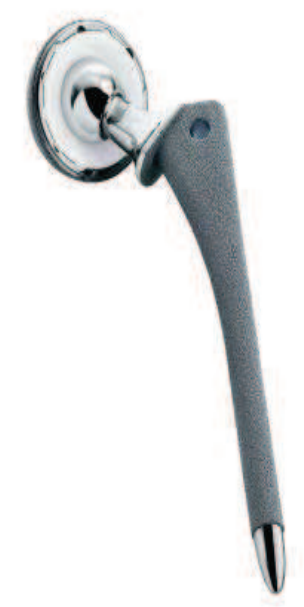

Figura 3.17- Implante AML. [SULLO \& SULLO LLP..., 2011].

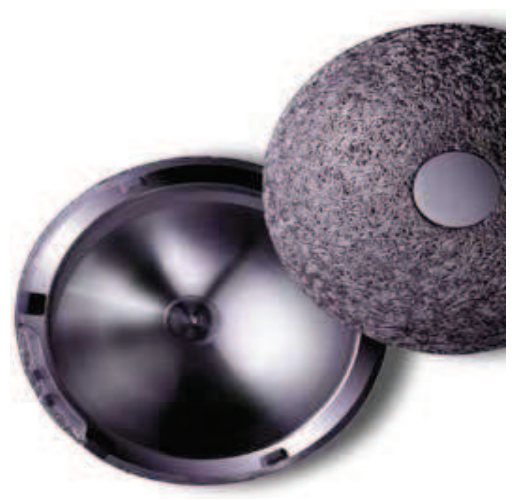

Figura 3.18- Implante HGP. [TRILOGY®..., 2008].

Durante o desenvolvimento dos implantes sem cimento, Harris (1992) e colaboradores tem descrito os elementos de cimentação que eram comuns em resultados com sucesso, como por exemplo, a redução da incidência de soltura do componente femoral e aumento de sobrevida de hastes femorais em pacientes jovens (BARRACK; MULROY JR; HARRIS, 1992).

Modos de falhas também influenciam os projetos de implantes, como por exemplo, o descolamento do implante onde o cimento foi à primeira causa de falha que levou ao desenvolvimento de uma melhor interface entre a haste e cimento (CORNELL, 1986). Ainda existe muita controvérsia quanto à rugosidade superficial ideal para hastes cimentadas e sem cimento ou fixação cimentada que deve ser utilizada (PETERSEN, 2003).

O implante total de quadril híbrido foi baseado em duas primeiras observações: uma fixação confiável sobre o lado femoral com cimento sem dor na coxa e o stress shielding proximal - que é definido como elevada taxa de reabsorção óssea na porção proximal do 
fêmur. Esta reabsorção é decorrente da fixação distal do componente femoral, diminuindo a solicitação mecânica da parte proximal, tendo como conseqüência a reabsorção da massa óssea local de acordo com a lei de Wolff (ENGH; BOBYN, 1988; ATLAS et al., 1994) - já visto anteriormente em implantes com cimento; trata-se de uma teoria estabelecida cientificamente dizendo que o osso responde aos esforços mecânicos com modificação de sua arquitetura interna. Como corolário, pode-se inferir que a estrutura normal de um osso guarda relação com as solicitações mecânicas. Isso pode ser comprovado pelo simples exame da estrutura trabecular do osso, por exemplo, no terço proximal do fêmur. Nessa região há dois feixes principais de trabéculas. Um, mais verticalizado, origina-se do topo e porção central da cabeça femoral, passa pela região medial do colo, onde se concentra, constituindo o calcar femoral para, distalmente, esparramar-se em direção da diáfise. Esse conjunto de trabéculas presta-se à descarga de forças de compressão que provêm da pelve (PESSAN, VOLPON, SHIMANO, 1996).

As cavidades sem cimento, no entanto, apresentam uma fixação confiável e se mostram claramente superiores nas revisões das cirurgias. Foi isso que levou à utilização de um componente femoral cimentado e um socket (porta acetábulo) que foi dado o nome de "híbrido" (PETERSEN, 2003).

De acordo com Petersen (2003), o foco atual das substituições totais de quadril não está mais relacionado à sua fixação e sim, aos fragmentos (debris) produzidos pelo desgaste e suas conseqüências, como mostra a Figura 3.19. A maior parte das atenções está em fragmentos de polietileno e da resposta clínica para pequenas partículas. Isto levou ao uso de sistemas de quadril de cerâmica/plástico, cerâmica/cerâmica e metal/metal. Mais recentemente, tem sido desenvolvidos polietilenos com ligações cruzadas para reduzir significativamente as taxas de desgaste quando comparadas ao polietileno original. O futuro das substituições totais de quadril poderia ser impressionante se os fragmentos do desgaste e os problemas de fixação pudessem ser eliminados, assim, as possibilidades de sucesso poderiam ser ilimitadas. 


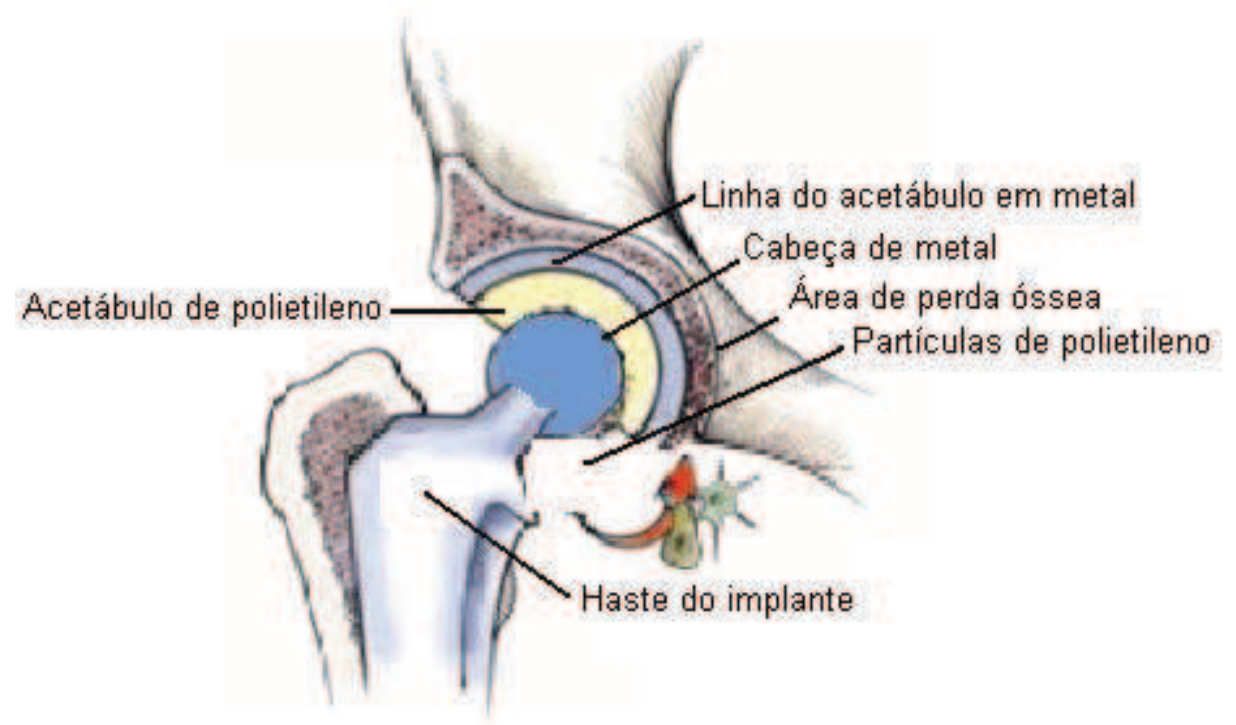

Figura 3.19- Os fragmentos de desgaste são um dos principais problemas modernos associados à substituição de quadril. As partículas de polietileno da linha do acetábulo são atacadas pelo sistema imune do paciente, destruindo o osso ao redor do implante, com eventual soltura.

[PETERSEN, 2003].

\subsubsection{Instrumental cirúrgico para recapeamento}

Com o avanço tecnológico e as novas técnicas cirúrgicas criadas ao longo dos anos de evolução, um número de instrumentos foi idealizado e utilizado pelos diversos cirurgiões durante a história da cirurgia. A palavra cirurgia significa operação manual, pois deriva do grego cheir (mão) e ergon (trabalho). É evidente que um ato cirúrgico requer também instrumentos para aumentar a destreza do operador e possibilitar a realização de manobras impossíveis de serem executadas apenas com as mãos. O termo instrumento é usado para denominar cada peça do instrumental, em particular; e instrumental, o conjunto destas peças. O número de instrumentos cirúrgicos é incontável; ao longo dos tempos os cirurgiões vêm criando e modificando novos elementos, que vão sendo incorporados aos já existentes. Quase sempre levam o nome de seus idealizadores, muitas vezes diferindo apenas em detalhes muito pequenos (ALMEIDA; ALMEIDA, 2010).

$\mathrm{Na}$ literatura, foram encontrados a The Conserve (Wright Medical Technology) utilizada por Amstutz et al., 1998; Corin - Cormet ${ }^{\circledR}$ (Operative Technique for the Cormet $($ ) Resurfacing Hip System, 2001) e Seyler et al., 2006 que utilizaram os instrumentais da Conserve Plus (Wright Medical, Arlington, TN). Cada autor prefere uma determinada 
abordagem, sendo a póstero-lateral utilizada por AMSTUTZ e colaboradores, a abordagem utilizada pela Corin foi à ântero-lateral e a póstero-lateral e Seyler e colaboradores utilizaram a abordagem ântero-lateral.

Amstutz et al., 1998 descrevem a técnica operatória utilizando instrumentos da The Conserve (Wright Medical Technology). A seguir, são descritos e ilustrados os procedimentos da artroplastia de recapeamento de quadril em humanos em função da quase que completa incipiência dessas informações relativamente aos animais, em particular aos cães. As informações aqui descritas certamente podem ser adaptados e eventualmente utilizados em um futuro próximo a artroplastia de recapeamento de quadril de cão.

O planejamento pré-operatório é útil na avaliação do tamanho e orientação da substituição do recapeamento. O paquímetro e/ou modelo de raio-X são utilizados para avaliar e para fornecer a dimensão do colo do fêmur, o centro da cabeça femoral e o tamanho aproximado da substituição do recapeamento. O diâmetro do colo femoral em seu maior plano é um fator limitante no dimensionamento do componente femoral. Geralmente, o maior plano é observado na perspectiva medial/lateral. Para a substituição do recapeamento não se deve nunca "entalhar" o colo do fêmur.

A abordagem utilizada por Amstutz et al., (1998) é a abordagem póstero-lateral, devido à capacidade de visualizar completamente o acetábulo, bem como a circunferência da cabeça e colo femoral. Esta visão permite uma rigorosa avaliação da cartilagem articular e otimiza uma precisão apropriada para uma melhor qualidade da cartilagem, se é central ou ao redor da periferia. Além disso, a opção está disponível para remover o trocânter maior a fim de melhorar a visualização. Recomenda-se o seccionamento do tendão do glúteo máximo no ponto de inserção na linha áspera. Em seguida, divide-se os $\mathrm{mm}$. rotadores, incluindo o tendão do m. piriforme que deve ser marcado para ser reparado mais tarde.

Para mobilizar a cabeça femoral, o ligamento teres é seccionado, se necessário, e a capsulotomia é concluída. A totalidade da cápsula deve ser liberada circularmente para assegurar uma visualização adequada do acetábulo. Além disso, a liberação irá facilitar a colocação do pino abaixo do eixo central do colo. A cápsula pode ser removida completamente para melhorar a visualização. O quadril agora pode ser rodado internamente e a cabeça femoral entregue para a inspeção e colocação do pino central.

\subsubsection{Centragem do pino}

O pino-guia de centragem é posicionado usando um goniômetro entre $135-145^{\circ}$, a fim de que o pino forme um ângulo de aproximadamente $140^{\circ} \mathrm{com}$ o eixo femoral. O ponto 
de entrada do pino é consistente com a posição determinada pelo modelamento. O pino deve ser centrado no meio do colo, no plano frontal (vista AP) e anterior ao centro do colo e direcionado ligeiramente posterior para anterior no plano coronal evitando-se a furação dentro do osteófito anterior. Um pino Steinman de 3,2 milímetros é inserido em seguida a uma profundidade de 3,0 a 5,0 centímetros, usando o guia para evitar que o pino se movimente fora da linha durante a inserção. A medida do furador cilíndrico antecipa o tamanho final. É então usada para verificar o posicionamento do pino e deverá ser capaz de rodar livremente, com apuramento suficiente ao redor do colo para garantir que a furação cilíndrica não resulte em entalhamento do colo do fêmur. Se o gabarito furador cilíndrico alcançar o colo a qualquer momento, o pino tem que ser reposicionado utilizando o recolocador de guia, que está ilustrado na Figura 3.20 e Figura 3.21. É especialmente importante proteger o córtex lateral, que é mais fino do que o lado medial e sofre tração de carga para diminuir o risco de fratura colo do fêmur.

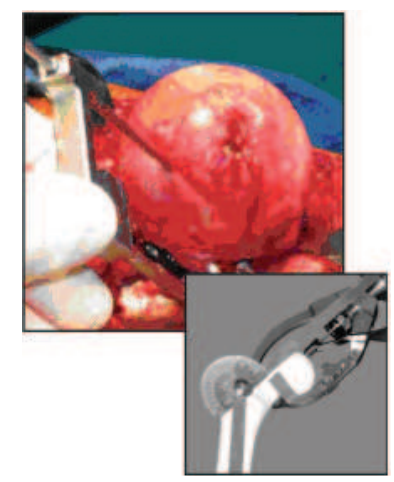

Figura 3.20- Verificação do posicionamento do pino. [AMSTUTZ et al, 2006].

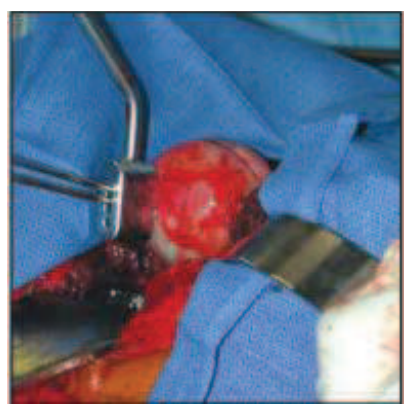

Figura 3.21- Recolocador de guia. [AMSTUTZ et al, 2006].

\subsubsection{Furação cilíndrica}

A furação começa com um furo excessivamente grande, geralmente de dois a três tamanhos maiores que o tamanho final, enquanto é irrigado abundantemente para evitar aquecimento. Pequenos furos são então usados analogamente abaixo do tamanho maior do 
modelo final e tamanho antecipado. Deve-se ter cuidado para parar a furação na junção da cabeça e colo femoral evitando cuidadosamente o entalhamento lateral do colo. Isto é essencial porque o furo a $140^{\circ}$ é geralmente maior do que o ângulo do colo (Figura 3.22).

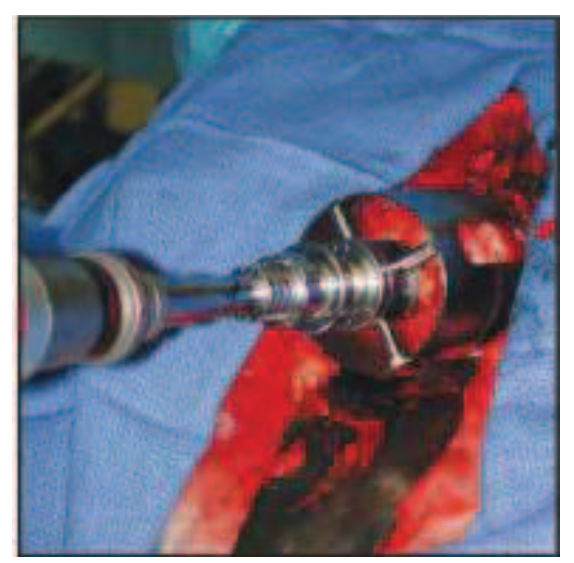

Figura 3.22- Furação a $140^{\circ}$. [AMSTUTZ et al, 2006].

\subsubsection{Preparação femoral final}

A cabeça femoral é liberada e rodada internamente auxiliada por uma toalha entre a coxa do cirurgião e a perna (Figura 3.23).

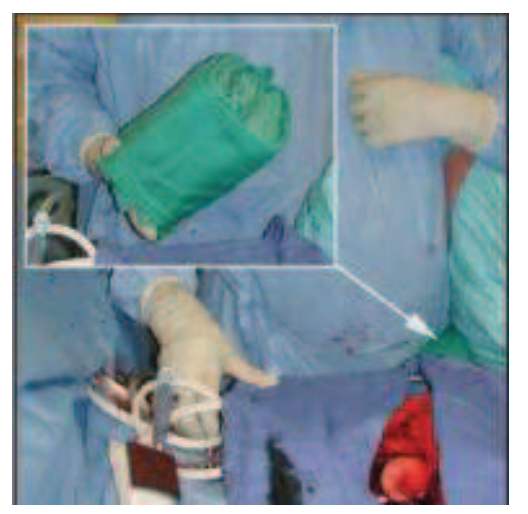

Figura 3.23- Preparação femoral com auxílio de uma toalha. [AMSTUTZ et al, 2006].

Uma verificação final é feita para a orientação do pino e uma correção pode ser necessária antes do furo no tamanho final. A serra de corte guia é posicionada de modo que a sua margem inferior abranja todo o diâmetro do furo do osso na junção cabeça-colo. Dois pinos curtos são inseridos no guia para furar e para manter a posição de corte de guia 
durante a ressecção da cúpula com uma espada ou serra oscilante. A remoção dos destroços deve ser feita de modo que o alinhamento do guia seja posicionado reto no topo da guia de corte e rodado até ser ajustado. O primeiro furo é feito utilizando uma broca do centro para o furo final para diminuir a metáfise da haste (Figura 3.24).

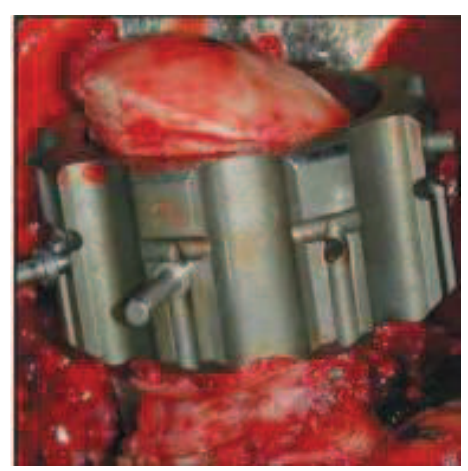

Figura 3.24- Remoção dos destroços de modo que o alinhamento do guia seja posicionado reto no topo da guia de corte e rodado até ajustar. [AMSTUTZ et al, 2006].

A profundidade de furação dependerá do método escolhido de fixação da haste sendo uma ou duas dimensões mais profundas para a haste cimentada. O guia adequado para chanfradura é inserido no furo após a remoção dos guias de alinhamento e de corte e o formato final da cabeça femoral que foram obtidas com o chanframento (Figura 3.25).

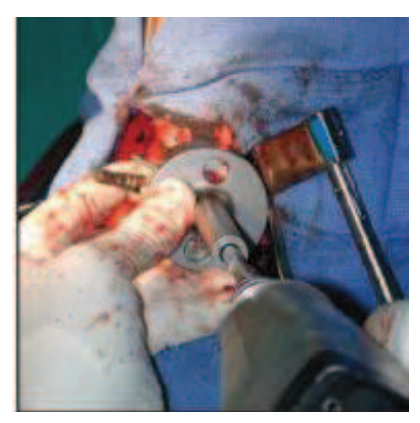

Figura 3.25- Chanframento da cabeça femoral [AMSTUTZ et al, 2006].

Quando estoque ósseo é bom, é possível realizar o chanframento com um tamanho maior (até 2 tamanhos) para a remoção de menos osso. Coloca-se um receptor sobre a cabeça femoral antes do chanframento para coleta dos fragmentos ósseos (Figura 3.26). 


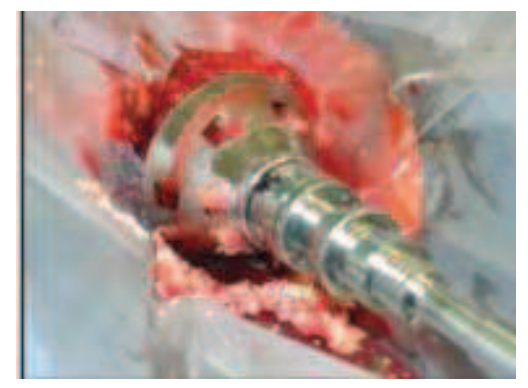

Figura 3.26- Colocação de um receptor para coleta de fragmentos ósseos.

[AMSTUTZ et al, 2006].

Uma última verificação do formato da cabeça femoral é feita pelo teste de rotação da cabeça do fêmur. No teste, a cabeça femoral deve rodar livremente para garantir um manto de cimento de cerca de 1,0 milímetro ao redor da cabeça femoral. Todos os materiais císticos e tecidos moles devem ser removidos para preparação da cabeça femoral com uma cureta afiada e rebarbas e fixação de furos adicionais feitos em ambos, na cúpula e nas áreas chanfradas não-porosas utilizando broca de 1/8" ou 3,2 milímetros. Geralmente, 6 a 8 furos são feitas na cúpula e 12 a 14 furos na área chanfrada (Figura 3.27).

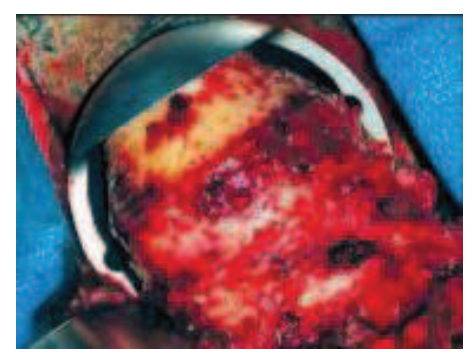

Figura 3.27- Verificação do formato da cabeça femoral. [AMSTUTZ et al, 2006].

\subsubsection{Cimentação da cabeça femoral}

Antes de cimentação, a cabeça femoral é lavada com jato livre de qualquer gordura ou fragmento e irrigada com antibiótico. A ponta de sucção é então inserida através do buraco da haste e conectada à parede de sucção. Uma cânula de sucção adicional com menor diâmetro é inserida em um furo de 3,2 milímetros no trocânter menor, 
de forma que fique perfeitamente encaixada. É importante manter a superfície femoral limpa e seca conforme mostra a Figura 3.28. Um pacote de cimento ósseo é então misturado e vertido apenas no componente femoral. $\mathrm{O}$ acrílico é pressurizado à mão no furo cilíndrico na porção da cabeça. Se a haste for cimentada, o cimento é pressurizado à mão abaixo do furo central. O componente femoral recebe o cimento acrílico em estágio de massa como mostra a Figura 3.29, onde o componente é totalmente assentado (se necessário, utilizar o impactador e martelo). A pressão é mantida até que o cimento tenha cura. Os excessos de cimento devem ser cuidadosamente aparados com um bisturi, assim o acrílico não é puxado para fora a partir da interface.
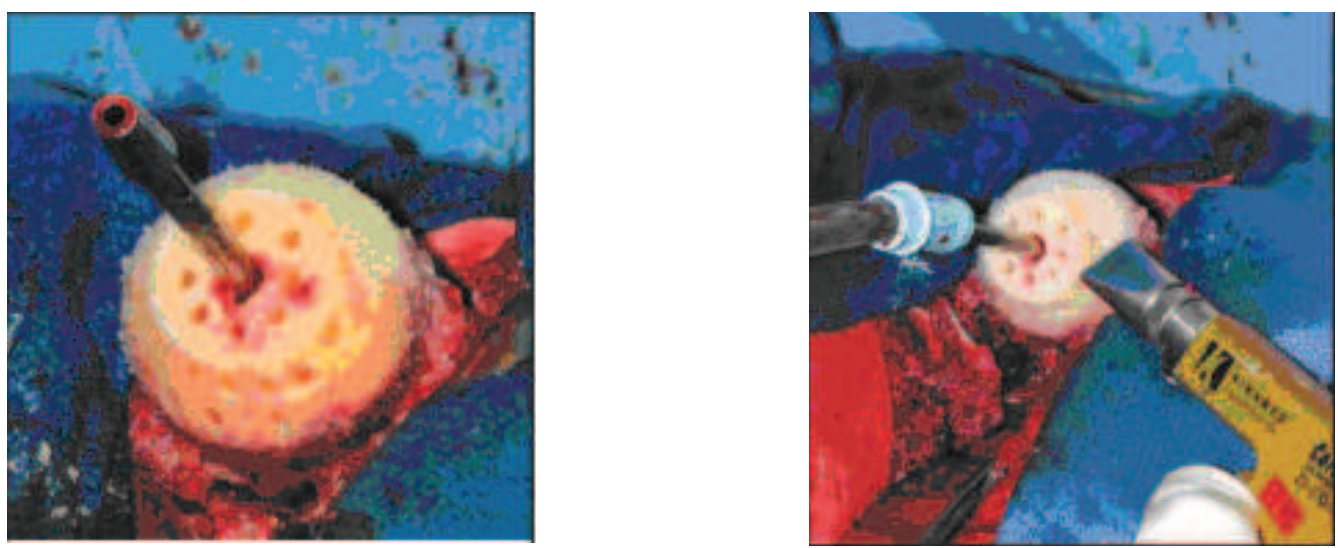

Figura 3.28- Superfície femoral limpa e seca. [AMSTUTZ et al, 2006].

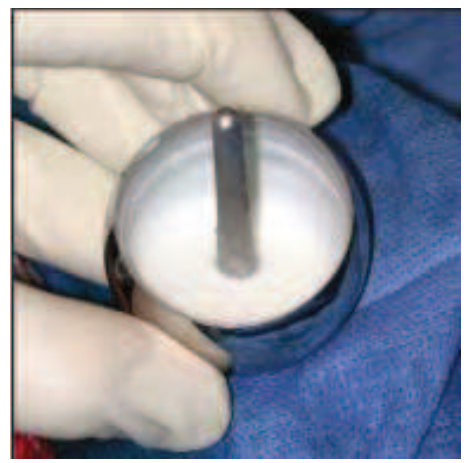

Figura 3.29- O componente femoral recebe o cimento acrílico. [AMSTUTZ et al, 2006]. 


\subsubsection{Redução do quadril e fechamento}

O quadril é reduzido e a cápsula é fechada quando possível. O músculo piriforme é recolocado. O re-ligamento do tendão do glúteo máximo é optativo. A ferida é então fechada com um ou dois drenos de sutura.

Já a técnica operatória da Corin - Cormet $₫$ (Operative Technique for the Cormet $₫$ Resurfacing Hip System, 2001) e o instrumental cirúrgico da Corin® (2001) compreendem uma seqüência de oito etapas que serão descritas a seguir.

\section{Preparação Inicial do fêmur - Pinos e Guias - Técnica Corin - Cormet®}

A posição do pino de referência para pré-furação lateral, conforme ilustra a Figura 3.30 é pré-determinada, medindo-se o fêmur com uma régua convencional. O pino lateral para a pré-furação é penetrado através de furação no meio do córtex lateral do fêmur, utilizando-se inicialmente a abordagem lateral, com uma angulação do pino na direção da cabeça femoral à medida que o córtex femoral é penetrado.

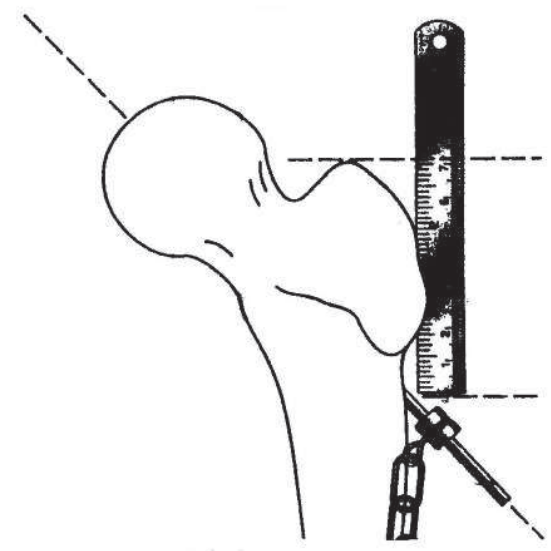

Figura 3.30- Medição da cabeça do fêmur. [OPERATIVE..., 2001].

\subsubsection{Dispositivo de Centragem}

Antes de continuar com a centragem da cabeça do fêmur, o tamanho do componente femoral deve ser confirmado colocando o gabarito apropriado da cabeça em volta do colo femoral. A folga apropriada disponível deve ser confirmada e o colo femoral não pode ser entalhado durante sua preparação. A ponta ajustável do dispositivo de centragem é montada para confirmar o tamanho da cabeça ao mesmo tempo em que o dispositivo de centragem é posicionado sobre o pino lateral. Um mecanismo tipo cremalheira permite que 
um tubo-guia possa avançar e ser posicionado sobre a cabeça femoral ao mesmo tempo em que a centragem é efetuada. A centralização do tubo-guia é obtida girando a ponta ajustável ao redor do colo. É importante que a ponta ajustável gire livremente ao redor do colo do fêmur na junção cabeça/colo, para evitar qualquer entalhamento no colo femoral. O tuboguia pode ser travado na posição definida tocando suavemente a cabeça femoral com os dentes da extremidade distal. Um pino-guia longo é então furado (ou penetrado) através do tubo-guia para dentro da cabeça do fêmur e o gabarito ou dispositivo de centragem é desmontado e removido. O tubo-guia e ponta ajustável podem então ser posicionados sobre o pino-guia para verificar se esse pino longo está posicionado corretamente em relação ao colo femoral. A Figura 3.31 ilustra o gabarito de centragem.

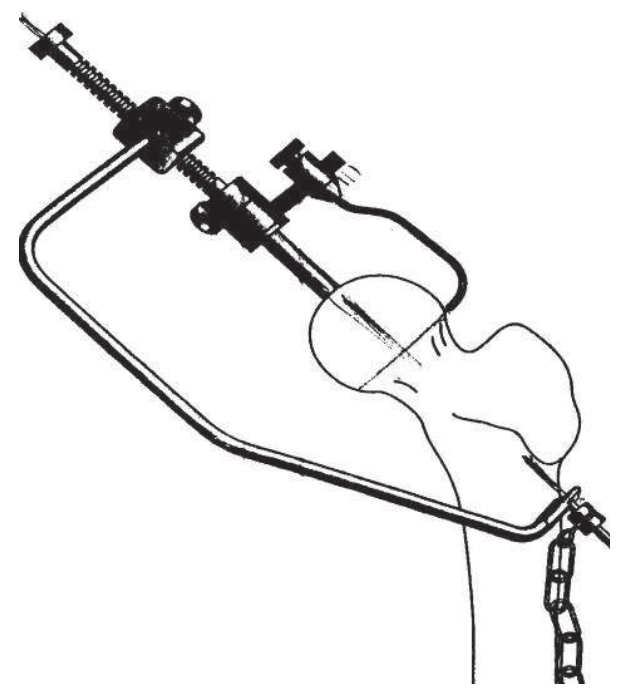

Figura 3.31- Preparação para a pré-furação. [OPERATIVE..., 2001].

\subsubsection{Furação com Broca Canulada}

A broca canulada de furação pode então ser avançada ao longo do pino-guia até onde a cabeça do fêmur possa ser utilizada. Tanto broca como o pino-guia são retirados e, em seguida, a haste-guia é inserida. A Figura 3.32 ilustra essa fase do procedimento de preparação da cabeça do fêmur para o recapeamento. 


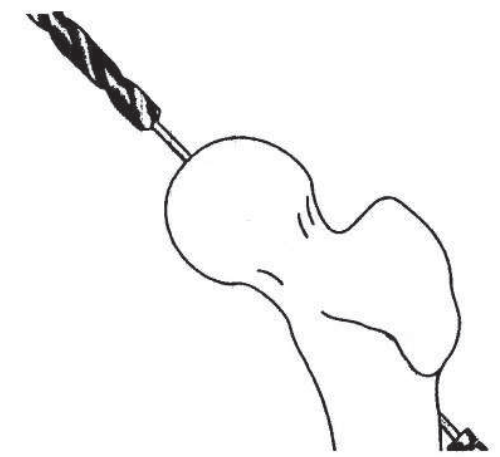

Figura 3.32- Furação com broca canulada. [OPERATIVE..., 2001].

\subsubsection{Refilamento da cabeça do fêmur}

O tamanho adequado do cortador de cabeça é avançado sobre a haste-guia, tanto na junção cabeça/colo, assegurando que o colo femoral não seja entalhado. O gabarito da cabeça pode ser posicionado ao redor do colo do fêmur para proteger o colo e o trocânter, e podem ser usadas ataduras para impedir a entrada de fragmentos no tecido mole. (Observação: um tamanho maior do cortador de cabeça pode ser usado para a preparação inicial, antes da preparação final, com o tamanho definitivo para refilar a cabeça (Figura $3.33)$.

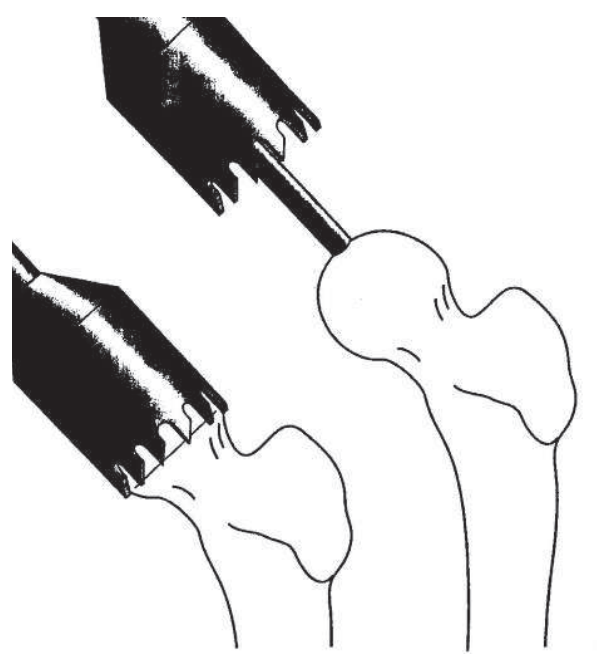

Figura 3.33- Refilamento da cabeça femoral. [OPERATIVE..., 2001]. 


\subsubsection{Guia para Plainamento da cabeça femoral}

A haste-guia é então removida e o guia da parte superior da cabeça é posicionado sobre a superfície preparada da cabeça e avançado para a junção cabeça/colo. O parafuso de bloqueio é apertado e a parte superior da cabeça femoral é seccionada. Um pino curto pode ser usado através do orifício da cabeça se a segurança adicional é requerida durante a secção da cabeça (Figura 3.34).

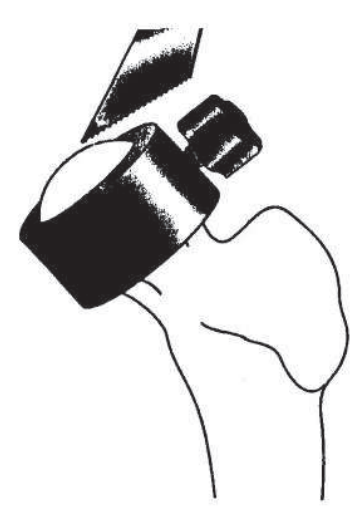

Figura 3.34- Plainamento da cabeça femoral. [OPERATIVE..., 2001].

\subsubsection{Plainamento da Cabeça do Fêmur}

A haste-guia é re-inserida e o cortador do topo da cabeça é avançado para criar uma superfície plana perpendicular ao eixo do colo conforme mostra a Figura 3.35.

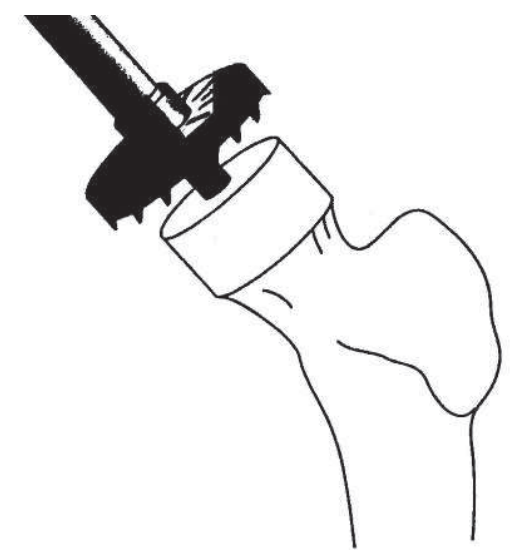

Figura 3.35- Preparação da superfície plana. [OPERATIVE..., 2001]. 


\subsubsection{Chanframento da Cabeça do Fêmur}

O cortador apropriado de chanfro é então usado para criar um chanfro na parte cilíndrica realizada. Devem ser tomados cuidados quando se utiliza este instrumento; o cortador deve avançar lentamente para evitar danos à superfície já trabalhada usando alta velocidade, em vez de refilar definindo a força da ferramenta como pode ser notado na Figura 3.36.

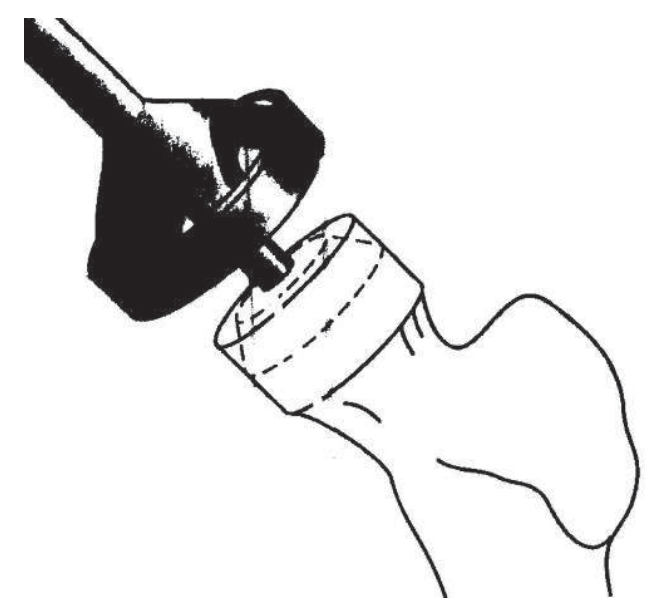

Figura 3.36- Chanframento da cabeça do fêmur. [OPERATIVE..., 2001].

\subsubsection{Medição e checagem da cabeça do fêmur usinada}

O tamanho do modelo correspondente da cabeça é usado para verificar o tamanho e preparar para fazer a marca na junção cabeça-colo para indicar até que ponto a componente femoral deve ser avançado completamente até ser assentado. Furos para o cimento de fechamento pode ser perfurado na cabeça femoral nesta fase, se necessário (Figura 3.37).

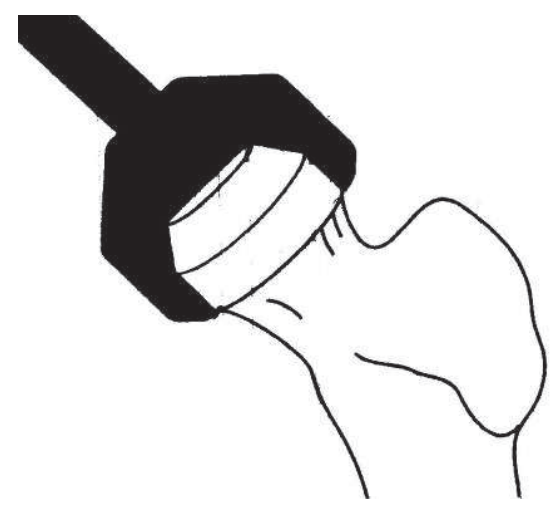

Figura 3.37- Medição e checagem do formato da cabeça do fêmur usinada.

[OPERATIVE..., 2001]. 


\subsubsection{Assentamento do Recapeamento do Fêmur}

Se a cabeça for cimentada, o cimento ósseo de baixa viscosidade é vertido para o componente femoral, até a linha no topo do chanfro no interior do implante. O componente definitivo é colocado sobre a cabeça femoral e impactado na posição com o impactador de cabeça. O excesso de cimento ósseo é removido. O cimento ósseo de baixa viscosidade deve sempre ser utilizado neste implante, pois que o cimento de alta viscosidade impede o pleno assentamento do componente. As cabeças sem cimento são simplesmente impactadas na posição com o impactador de cabeça. O quadril é então reduzido, evitandose riscar o componente femoral contra a borda da taça acetabular. Uma verificação plena, em seguida, é feita para garantir que não haja impacto e que o movimento seja satisfatório (Figura 3.38).

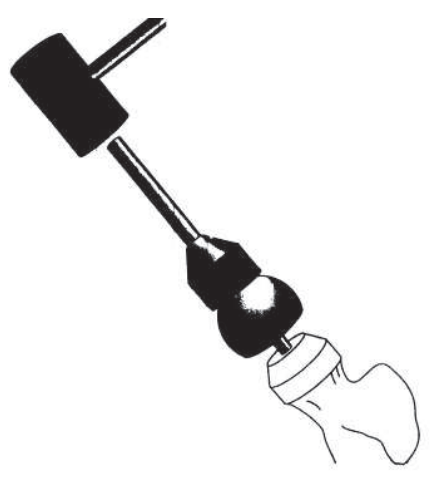

Figura 3.38- Assentamento do recapeamento. [OPERATIVE..., 2001].

Já, Seyler et al., (2006) utilizaram a abordagem ântero-lateral. Após a colocação do paciente em decúbito lateral, o trocânter maior é marcado e a cabeça femoral é localizada, determinando a partir de radiografias pré-operatórias e palpação direta nas marcas (Figura 3.39). 


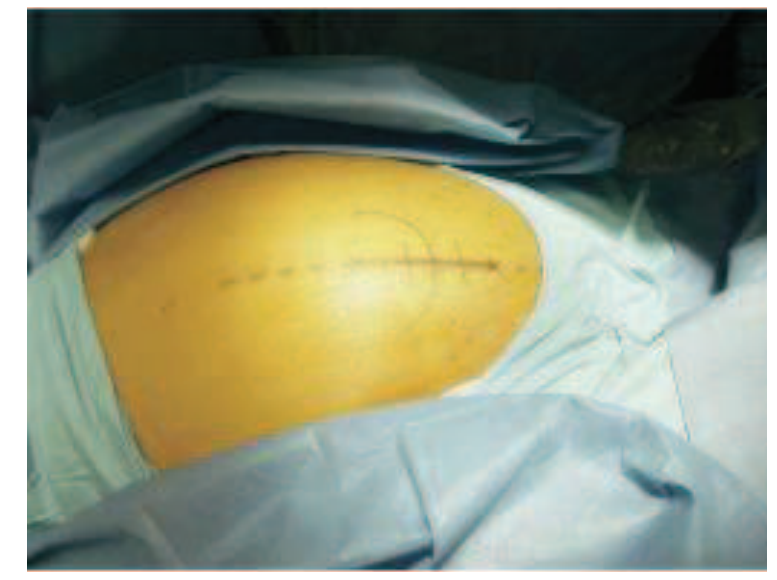

Figura 3.39- Palpação e marcação da linha de incisão. [SEYLER, et al,, 2006].

O próximo passo dessa abordagem é o aprofundamento da pele através da incisão do tecido subcutâneo em nível do músculo tensor da fáscia lata. Um retrator é usualmente suficiente para a retração do tecido e prover o tamponamento de veias subcutâneas conforme ilustra a Figura 3.40.

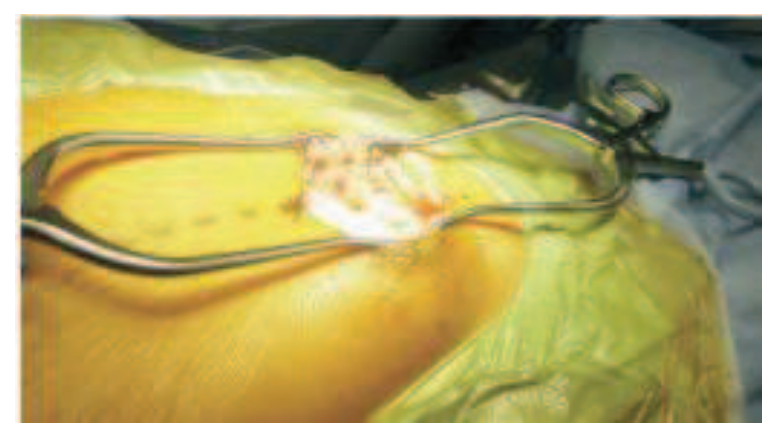

Figura 3.40- O retrator permite retração e exposição profunda do tecido mole.

[SEYLER, et al., 2006].

\subsubsection{Exposição do acetábulo}

Esta parte é a mais desafiadora da artroplastia de recapeamento. O quadril é colocado em vários graus de flexão para exposição adequada do acetábulo. Normalmente, 30 a $40^{\circ}$ graus de flexão do quadril são suficientes para permitir que a cabeça femoral seja retraída posteriormente. Primeiro, um retrator angular anterior é colocado na direção ântero- 
inferior. Em seguida, um Hohmannn angular é posicionado ao longo da borda acetabular póstero-inferior. Um retrator perfurante de Mueller é colocado acima da borda superior do acetábulo entre o labrum e a cápsula superior. Inferiormente, a cápsula medial é excisada de maneira elíptica e o tendão do m. psoas é identificado para evitar o corte. A cápsula medial permite a liberação adicional da translação posterior do fêmur para exposição acetabular. Em muitos pacientes, essas medidas serão suficientes para proporcionar a preparação adequada para a exposição acetabular. Pode haver situações em que a escolha da deformidade da cabeça femoral, como no caso de uma epífise anterior femoral, não permitirá a exposição adequada. Particularmente, nestes pacientes a osteotomia da cabeça femoral alinhados com o colo do fêmur pode ser efetuada de modo que se obtenha mais exposição. É importante evitar entalhes no colo femoral, pois aumenta o risco de fratura do colo do fêmur. Uma exposição e visualização adequada são obtidas através do escareamento inicial do acetábulo como pode ser observada na Figura 3.41.

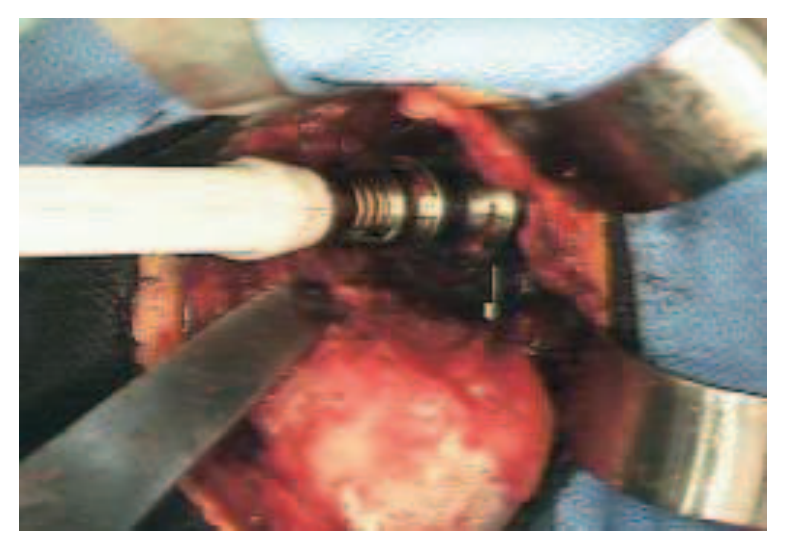

Figura 3.41- $A$ exposição adequada permite o escareamento do acetábulo.

[SEYLER, et al., 2006].

Como não existe atualmente um componente acetabular com a cavidade disponível para parafuso, a furação concêntrica é indispensável e uma radiografia intra-operatória pode ser necessária para confirmação da posição e impactação do componente acetabular. Após a colocação do componente acetabular, os osteófitos anterior ou posterior sobressaem-se e devem ser removidos cuidadosamente com um osteótomo. A excisão de osteófitos é um passo importante para a realização máxima do movimento, evitando-se que o componente femoral ou o colo sejam afetados. 


\subsubsection{Recapeamento da cabeça femoral}

O quadril é rodado externamente, e as margens da pele devem ser protegidas com uma variedade de retratores. Os autores preferem uma combinação de retratores de Bennett e Richardson para a proteção dos tecidos moles. Um pino guia de 3,2 mm é colocado na cabeça femoral alinhado com o colo femoral com um ângulo de 135 a $140^{\circ}$ que é medido através de um goniômetro conforme mostra a Figura 3.42.

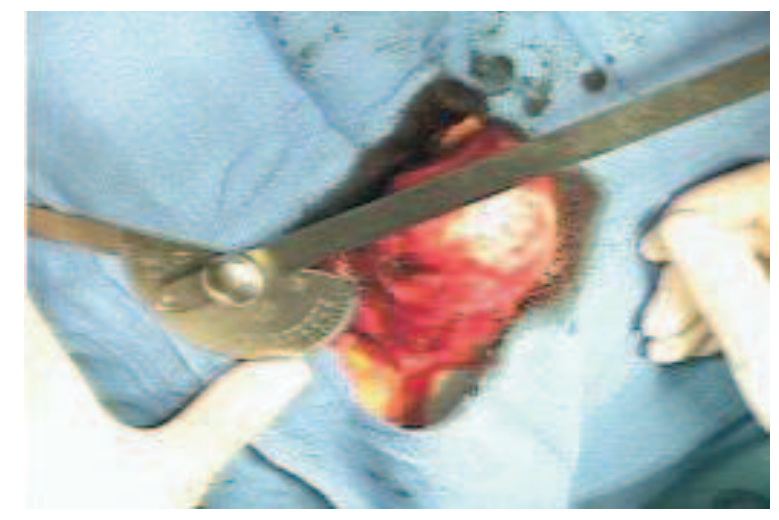

Figura 3.42- Posicionamento correto de um pino guia de 3,2 $\mathrm{mm}$ com uso de um goniômetro. [SEYLER, et al., 2006].

A colocação adequada do pino no centro do colo femoral é confirmada com um giro ao redor do guia para verificação da colocação do pino excêntrico como mostra a Figura 3.43 .

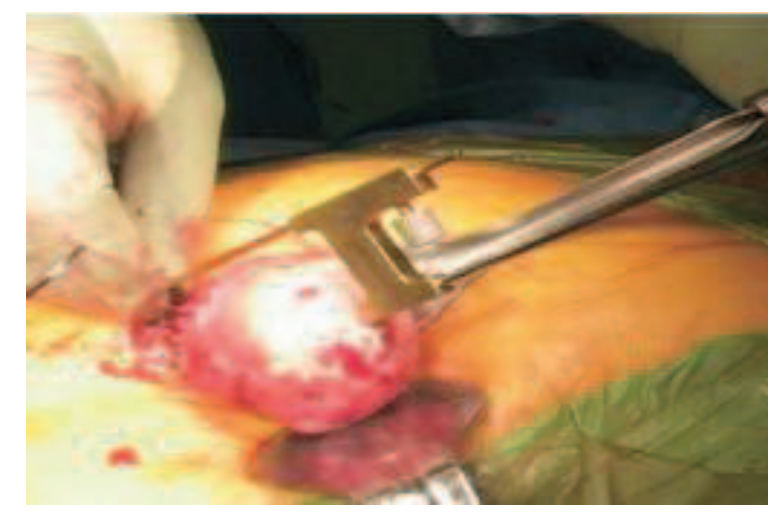

Figura 3.43- Posicionamento do pino no centro do colo femoral. [SEYLER, et al., 2006]. 
Após a inserção do pino guia, o eixo trans-epicondilar do joelho é colocado paralelo ao plano do colo e o ângulo do pino femoral é medido para confirmar um ângulo de $135^{\circ} \mathrm{a}$ $140^{\circ}$ como mostra a Figura 3.44 .

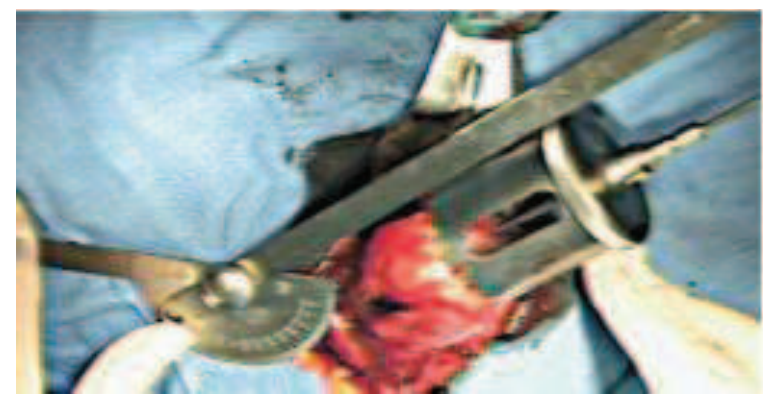

Figura 3.44- Antes de iniciar o escareamento cilíndrico da cabeça femoral, o pino femoral é medido com um goniômetro para confirmar o ângulo entre 135 a 140. [SEYLER, et al., 2006].

Um guia de corte é colocado ao redor do colo femoral para capturar os pedaços ósseos na fase de escareamento. A seguir, a cabeça femoral é inicialmente furada com um furo cilíndrico de 6,0 mm, maior que o tamanho final, sendo determinado pelo diâmetro interno do componente acetabular. O guia é usado novamente para confirmar a localização central no colo femoral, evitando-se assim o entalhamento. Se o potencial de entalhe não existe, o pino avança 1,0 ou $2,0 \mathrm{~mm}$, usando um dispositivo que o avança cuidadosamente na direção apropriada para não alterar o ângulo do eixo. Em caso de dúvida, o ângulo do eixo deve ser novamente verificado com o goniômetro.

Com a confirmação apropriada da posição do pino, o escareamento cilíndrico final da cabeça femoral é realizado. O guia de aplainamento inicial de 3,2 $\mathrm{mm}$ é removido, e o guia é colocado ao redor da cabeça femoral para escareamento cilíndrico e é posicionado para escarear 5,0 a 10,0 mm da cabeça femoral proximal (Figura 3.45). 


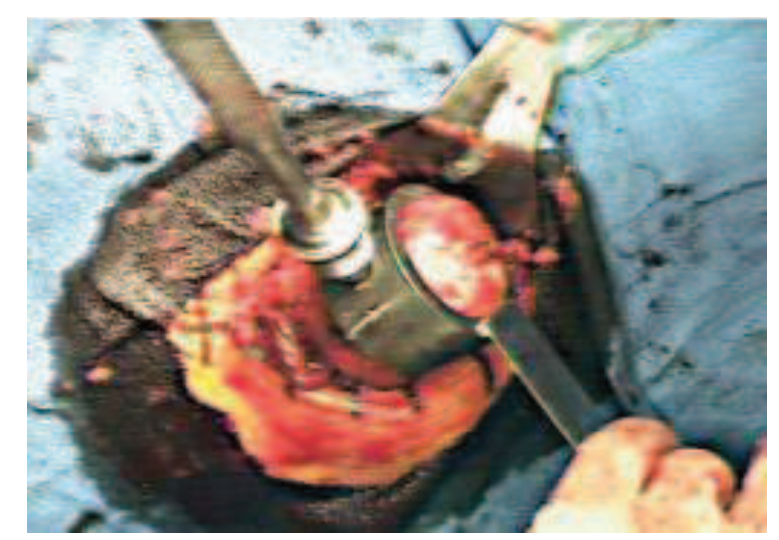

Figura 3.45- Uso de guia cilíndrico para escareamento da cabeça femoral.

[SEYLER, et al., 2006].

Um furo central é então perfurado através de um guia com profundidade adequada para encaixe de uma haste curta. O pino guia central é colocado no furo central para a realização do chanfro. Os cortes de chanfro são feitos com cuidado especial para não ocasionar torque no colo femoral. A chanfradura deve ser iniciada no osso e avançando gradualmente para a cabeça femoral. Deve-se assegurar que o furo central seja profundo o suficiente para permitir que o processo de assento plano com o corte da cabeça femoral proximal seja realizado. Se não for o caso, o furo central deve ser alargado. O componente femoral é cimentado no lugar, após a cabeça femoral ser irrigada, seca e livre de quaisquer tecidos moles ou debris (Figura 3.46). O excesso de cimento deve ser removido e o quadril é reduzido, como mostra a Figura 3.47 .

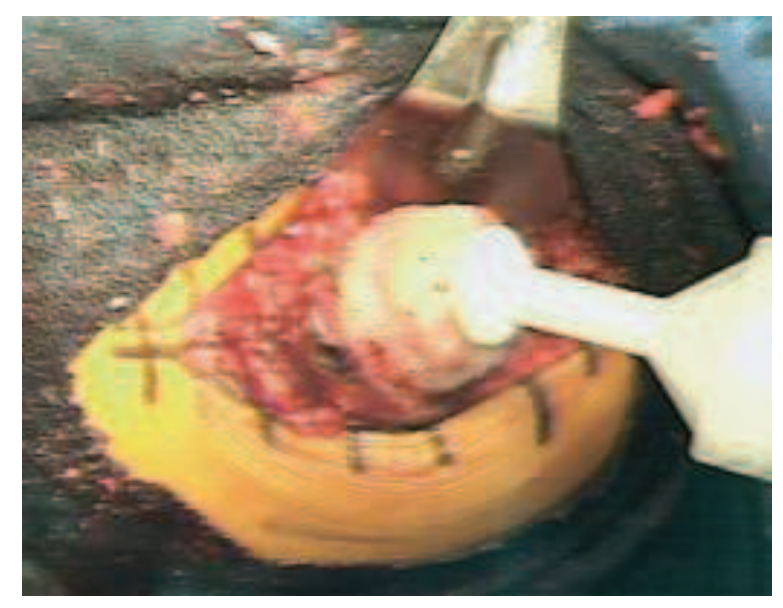

Figura 3.46- O componente femoral cimentado no local. [SEYLER, et al., 2006]. 


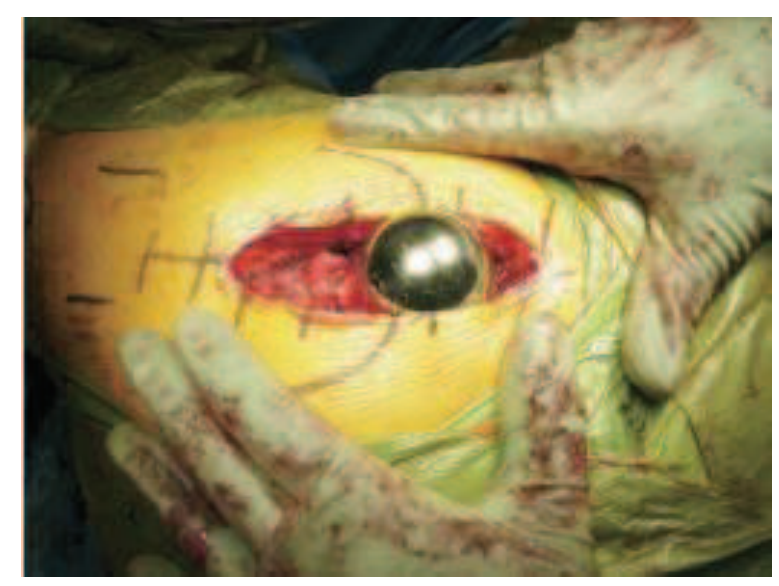

Figura 3.47- Após o cimento ser curado, o quadril é reduzido e os componentes femoral e acetabular são testados. [SEYLER, et al., 2006].

Atualmente como já citado, não existem na literatura, artigos sobre artroplastia de recapeamento de quadril em cães sendo assim, nada foi encontrado a respeito de um ferramental utilizado para esta técnica, motivos estes que estimulam o desenvolvimento deste trabalho bem como o detalhamento das artroplastias de recapeamento de quadril ora apresentados.

\subsubsection{Ferramental cirúrgico para artroplastia total de quadril}

Devido ao crescente desenvolvimento dos materiais cirúrgicos e ao aumento da longevidade da população, o procedimento de artroplastia total de quadril vem se tornando cada vez mais freqüente. As técnicas cirúrgicas desenvolveram-se acentuadamente nos últimos anos, entretanto, ainda existem controvérsias a serem resolvidas.

As cirurgias na articulação do quadril, em particular as artroplastias, são realizadas mediante vias cirúrgicas de abordagem que, embora consagradas pelo uso, podem apresentar consideráveis dificuldades de execução, dependendo da patologia de base e do biotipo do paciente. Além disso, podem trazer complicações na reconstituição dos planos anatômicos, após o término da etapa cirúrgica principal. No desenvolvimento do acesso cirúrgico, a inexistência de uma via padrão para cada tipo de acesso, independente do tipo de técnica aplicada, deve-se levar em consideração o tipo de acesso que permita a exposição adequada da região que se pretende atuar, diminuindo ao máximo a possibilidade 
de traumatizar estruturas importantes, não diretamente envolvidas no procedimento cirúrgico e que possa permitir acesso direto à região alvo (LIMA, XAVIER e VOLPON, 1994).

Howell, Garbuz e Duncan (2004) destacam que os instrumentos cirúrgicos são designados para ajudar na exposição, facilidade na preparação óssea e a inserção do componente.

Os instrumentos cirúrgicos representam um elevado investimento, tanto em hospitais quanto em clínicas. Todos os detalhes devem ser minuciosamente levados em conta para que o instrumental esteja de acordo com a garantia do fornecedor, desde seu acondicionamento até sua limpeza e esterilização. A maioria dos instrumentos cirúrgicos é fabricada em aço inoxidável, muitas vezes não seguindo normas técnicas, pois atualmente existe uma grande variedade de tipos de aços.

Segundo a ABNT (1997) para os instrumentos cirúrgicos são utilizados aços inoxidáveis martensíticos, que são ligas de $\mathrm{Fe}, \mathrm{C}, \mathrm{Cr}$ com pequenas quantidades de $\mathrm{Ni}$, sendo os tipos mais comuns classificados de acordo com as normas AISI (403, 410, 414, 416, 420, 420F, 431, 440A, 440B, 440C, 440F).

Atualmente, existem instrumentais de diversas marcas e modelos que são utilizados na ortopedia humana. Exemplos de instrumentais cirúrgicos utilizados em ortopedia estão listados no Anexo 2.

\subsubsection{Tipos de materiais utilizados em próteses de quadril}

A importância da qualidade de um material empregado para implantes de quadril vem crescendo à medida que se tornam evidentes as exigências relacionadas às necessidades do paciente, projeto e fabricação do implante. Sendo assim, atualmente existem inúmeros materiais utilizados em implantes, cada um com as suas vantagens e desvantagens.

A utilização dos primeiros materiais inseridos no corpo humano ocorreu em épocas bem remotas, tendo como primeira necessidade à redução da infecção, que freqüentemente acompanhava essas tentativas.

Do ponto de vista mecânico, os implantes de um modo geral são relativamente simples, contudo as necessidades de biocompatibilidade do material tem sido difíceis de serem atendidas (ZAVAGLIA, 1993; WILLIAMS, 1987). 
Os novos materiais devem ser biocompatíveis e se classificam em três categorias: materiais bioativos, bioinertes e biotoleráveis, conforme o aspecto da interação química com o tecido humano (SAWAKI; KAWASAKI e ZILIOTTO, 1992).

Os materiais bioativos são aqueles que proporcionam ligações de natureza química entre o material e o tecido ósseo, induzindo a osteointegração. Esses materiais promovem uma resposta biológica específica na interface do material que resulta na união entre os tecidos e o material (HENCH et al., 1972). Em função da similaridade química entre estes materiais e a parte mineral óssea, os tecidos ósseos se ligam a estes materiais, permitindo a osteocondução através do recobrimento por células ósseas. Os principais materiais desta classe são os vidros bioativos e as vitro-cerâmicas à base de fosfatos de cálcio, a hidroxiapatita e os compostos de fosfato de cálcio.

Os materiais bioinertes são aqueles também tolerados pelo organismo, mas a formação de envoltório fibroso é mínima, praticamente inexistente. O material não libera nenhum tipo de componente ou o faz em quantidades mínimas. A quantidade de células fagocitárias na interface é mínima, a resposta fagocítica é passageira e uma fina cápsula toma lugar após a colocação do implante. Em alguns casos esta camada é praticamente imperceptível. Os materiais bioinertes mais utilizados são a alumina, zircônia, titânio, ligas de titânio e carbono.

Segundo a Conferência da Sociedade Européia para Biomateriais realizada na Inglaterra em 1986 (WILLIAMS, 1987), o termo bioinerte, não é adequado, já que todo material induz algum tipo de resposta do tecido hospedeiro, mesmo que seja mínima e, de acordo com HENCH (1993) não existe material implantado em tecido vivo que seja completamente inerte, por este motivo, o termo bioinerte deve ser evitado. No entanto, o termo ainda é comumente utilizado, e é definido como um material que apresenta uma resposta interfacial mínima que não resulta na ligação ou na rejeição do tecido hospedeiro, formando uma cápsula fibrosa não aderente ao redor do material (WILLIAMS, 1987). Como exemplos de cerâmicas bioinertes podem ser citadas a alumina $\left(\alpha-\mathrm{Al}_{2} \mathrm{O}_{3}\right)$, zircônia $\left(\mathrm{ZrO}_{2}\right)$ e dióxido de titânio $\left(\mathrm{TiO}_{2}\right)(\mathrm{AOKI}, 1988)$.

Segundo CAMILO (2006) materiais biotoleráveis são aqueles apenas tolerados pelo organismo, sendo isolados dos tecidos adjacentes através de formação de camada envoltória de tecido fibroso. Esta camada é induzida pela liberação de compostos químicos, íons, produtos de corrosão e outros por parte do material implantado. Quanto maior a espessura da camada de tecido fibroso formada, menor a tolerabilidade dos tecidos ao material. Os materiais biotoleráveis são praticamente todos os polímeros sintéticos, assim como a grande maioria dos metais.

Os materiais reabsorvíveis são aqueles que após certo período de tempo em contato com os tecidos, são degradados, solubilizados ou fagocitados pelo organismo. 
Esses materiais são extremamente interessantes em aplicações clínicas, em função de ser desnecessária uma nova intervenção cirúrgica para a retirada do material de implante. Os principais exemplos destes materiais são as cerâmicas $\alpha$-tricálcio fosfato $(\alpha-T C P)$, $\beta$ tricálcio fosfato $(\beta-T C P)$, hidroxiapatita sinterizada (u-HAp), tetracálcio-fosfato (TTCP), octacálcio fosfato (OCP) e os polímeros ácidos polilático (Polilactide-PLA), ácido poliglicólico (Poliglicolide-PGA).

O desenvolvimento atual da Área Médica tem exigido que os implantes apresentem um elevado grau de desempenho para que possam cumprir de maneira adequada às funções da parte substituída ou reposta. É imprescindível, neste sentido, a utilização de materiais que apresentem boa biocompatibilidade e resistência satisfatória dentre outras características (KATTI, 2004).

Ultimamente, várias pesquisas estão sendo conduzidas na área de aplicação dos materiais avançados em próteses cirúrgicas artificiais, em particular na articulação de quadril com o objetivo de minimizar as complicações biomecânicas, especificamente o desgaste excessivo e os processos de corrosão dos materiais implantados (FRANKS, 1989).

Os materiais metálicos são usados em forma de ligas e geralmente apresentam alta resistência mecânica à tração, ao impacto, à fadiga e ao desgaste, mas possui algumas desvantagens dependendo do tipo de material metálico, como a baixa biocompatibilidade, corrosão em meio fisiológico, alta densidade e diferença de propriedades mecânicas em relação aos tecidos. Como exemplos têm-se os aços AISI F138, ligas de Co-Cr, titânio e ligas Ti6Al4V e Ti6Al7Nb.

A conseqüência da corrosão é um dos principais problemas dos implantes metálicos, ou seja, a perda de material que enfraquece o implante, e provavelmente o mais importante, os produtos da corrosão que irão para os tecidos ocasionando resultados indesejáveis. Já os materiais poliméricos têm uma grande variedade de aplicações para implantação porque eles podem ser facilmente fabricados em muitas formas como, por exemplo, fibras, tecidos, filmes, barras e líquidos viscosos. Os polímeros exibem certa semelhança com componentes dos tecidos poliméricos naturais como o colágeno. Em alguns casos, é possível conseguir uma ligação entre os polímeros sintéticos e os tecidos poliméricos naturais. Exemplos de materiais poliméricos são o polietileno, poliuretano, polimetilmetacrilato, silicone e poli (ácido láctico). (ARAUJO; COUTO, 2003).

Os materiais cerâmicos ou cerâmicas podem apresentar características interessantes para utilização como implantes ósseos, pois oferecem características desejáveis como a biocompatibilidade e inércia química em meio fisiológico, dureza e boa resistência mecânica à compressão, porém, baixa resistência à tração. Algumas das cerâmicas mais empregadas em implantes são a alumina, zircônia, hidroxiapatita, biovidros, vitro-cerâmicas e os compostos de fosfatos de cálcio. 
Já os materiais compósitos são formados através da associação de dois ou mais materiais, dos quais um será a matriz e os outros serão componentes de reforço, o que objetiva obter propriedades específicas para aplicações em implantes, dependendo dos materiais empregados.

Atualmente, diversos dispositivos protéticos são utilizados normalmente, conforme mostra a Tabela 3.3 que exemplifica as aplicações dos vários materiais para os diversos tipos de implantes.

Tabela 3.3- Exemplos de aplicações, vantagens e desvantagens dos biomateriais utilizados em implantes. [PARK, 1980; ZAVAGLIA, 1993].

\begin{tabular}{|c|c|c|c|c|}
\hline Materiais & Vantagens & Desvantagens & Exemplos & Aplicações \\
\hline Metais e ligas & $\begin{array}{c}\text { Alta resistência } \\
\text { mecânica à tração, ao } \\
\text { impacto, à fadiga e ao } \\
\text { desgaste }\end{array}$ & $\begin{array}{c}\text { Baixa } \\
\text { biocompatibilidade, } \\
\text { corrosão em meio } \\
\text { fisiológico, alta } \\
\text { densidade, diferença } \\
\text { de propriedades } \\
\text { mecânicas com } \\
\text { relação a tecidos } \\
\text { moles }\end{array}$ & $\begin{array}{c}\text { Pt, Pt-Ir, Au, aços } 316 \text {, } \\
\text { 316L, ligas Co-Cr, } \\
\text { titânio e ligas Ti6A14V e } \\
\text { Ti6A17Nb }\end{array}$ & $\begin{array}{l}\text { Eletrodos, fios, } \\
\text { placas, parafusos, } \\
\text { cravos, grampos, } \\
\text { pinos, próteses } \\
\text { articulares e } \\
\text { implantes dentários }\end{array}$ \\
\hline Polímeros & $\begin{array}{l}\text { Resiliência, facilidade } \\
\text { de fabricação, baixa } \\
\text { densidade, boa } \\
\text { biocompatibilidade } \\
\text { (reabsorvíveis) }\end{array}$ & $\begin{array}{l}\text { Baixa resistência } \\
\text { mecânica, } \\
\text { degradação } \\
\text { dependente do } \\
\text { tempo }\end{array}$ & $\begin{array}{l}\text { Polietileno, poliuretano, } \\
\text { polimetilmetacrilato, } \\
\text { politetrafluoretileno, } \\
\text { nylon, dracon, silicone e } \\
\text { ácido polilático }\end{array}$ & $\begin{array}{l}\text { Superfícies } \\
\text { articulares, vasos, } \\
\text { cartilagens, cimento } \\
\text { ortopédico, sutura, } \\
\text { substituição de } \\
\text { tecidos moles, placas } \\
\text { de reparação óssea. }\end{array}$ \\
\hline Cerâmicas & $\begin{array}{l}\text { Boa } \\
\text { biocompatibilidade, } \\
\text { resistência à corrosão, } \\
\text { inércia química, alta } \\
\text { resistência à corrosão, } \\
\text { resistência à tração }\end{array}$ & $\begin{array}{l}\text { Baixa resistência ao } \\
\text { impacto, dificuldade } \\
\text { de fabricação, baixa } \\
\text { reprodutibilidade de } \\
\text { propriedades } \\
\text { mecânicas, não é } \\
\text { resiliente, alta } \\
\text { densidade } \\
\text { Fragilidade }\end{array}$ & $\begin{array}{c}\text { Alumina, zircônia, } \\
\text { fosfato tricálcio } \\
\text { hidroxiapatita, biovidro, } \\
\text { carbono (fibra), carbono } \\
\text { (vítreo) e carbono } \\
\text { pirolítico }\end{array}$ & $\begin{array}{l}\text { Cabeça de fêmur, } \\
\text { odontologia, } \\
\text { reconstrução óssea, } \\
\text { ligamentos artificiais, } \\
\text { revestimentos } \\
\text { reabitáveis, } \\
\text { revestimentos } \\
\text { hemocompatíveis }\end{array}$ \\
\hline Compósitos & $\begin{array}{l}\text { Boa biocompatibilidade } \\
\text { inércia química, } \\
\text { resistência à corrosão, } \\
\text { alta resistência à } \\
\text { tração }\end{array}$ & $\begin{array}{l}\text { Dificuldade de } \\
\text { fabricação }\end{array}$ & $\begin{array}{c}\text { Teflon-carbono, } \\
\text { carbono-carbono, nylon- } \\
\text { poliuretano }\end{array}$ & $\begin{array}{l}\text { Cartilagens, } \\
\text { odontologia, } \\
\text { ortopedia, } \\
\text { substituições de } \\
\text { tecidos moles }\end{array}$ \\
\hline
\end{tabular}




\subsubsection{Materiais Metálicos}

Diversos metais e ligas têm provado serem satisfatórios como materiais para implantes, durante muitos anos de aplicação cirúrgica. Os implantes metálicos são especificados como materiais para implantes pelas normas da Sociedade Americana para Testes e Materiais (ASTM) e as da Organização Internacional para Normatização (ISO) e por outras normas nacionais. Esses materiais possuem resistência a corrosão e são bem aceitos pelos tecidos do corpo, sendo biocompatível, ou seja, satisfazem dois requerimentos básicos para implantes. Essas duas propriedades, geralmente, estão relacionadas porque quanto menos substâncias o material liberar, melhor será a aceitação do material pelo tecido (ARAUJO; COUTO, 2003).

A resistência a fadiga é outra necessidade essencial para implantes do quadril, mas o carregamento crítico é diferente para os vários tipos de implantes e aplicações. As propriedades mecânicas necessárias para implantes também apresentam variações e dependem da forma do implante e a aplicação (METALS..., 1980).

Do ponto de vista de resistência mecânica, em decorrência das distintas solicitações exigidas por um implante ósseo, até o presente momento não se conseguiu o desenvolvimento de um material que supere ou ao menos se iguale às ligas metálicas de grau cirúrgico (RIGO et al., 1999).

Segundo Zavaglia (1993) os aços inoxidáveis podem ser classificados com base na sua microestrutura que apresentam à temperatura ambiente: aços martensíticos, aços inoxidáveis ferríticos e aços inoxidáveis austeníticos. Os dois primeiros são essencialmente ligas de cromo-ferro e o terceiro tipo de material é constituído de ligas de ferro-cromo-níquel. O níquel foi introduzido devido a sua melhora considerável a resistência à corrosão do aço, além de propiciar uma restauração muito mais rápida da película inerte protetora, caso esta tenha sido danificada. No entanto, somente os aços inoxidáveis austeníticos atendem os requisitos necessários para um implante cirúrgico (SEMLITSH, 1984).

A corrosão por pite (pitting) é um dos maiores problemas na área da medicina, isto porque o material metálico no corpo humano sofre dissolução química ou reação eletroquímica com uma velocidade significativa. O emprego dos aços inoxidáveis em implantes ortopédicos continua sendo realizado por duas razões: sua maior resistência mecânica e seu custo mais baixo, quando comparados aos outros materiais não ferrosos (WALCZAK et al., 1998).

Uma pesquisa do Instituto de Química da USP desenvolvida por Villamil avaliou a resistência à corrosão de diversos tipos de aços inoxidáveis, usados em implantes ortopédicos. Os resultados indicam que as ligas têm obtido cada vez mais estabilidade, o 
que contribuirá para aumentar à meia-vida da prótese dentro do organismo, evitando procedimentos médicos devido à manutenção nas próteses. Em sua pesquisa, foi medida a oxidação sofrida por amostras de aços imersas em uma solução ácida, que simula as condições eletroquímicas de uma infecção no corpo humano. A primeira amostra, denominada $316 \mathrm{~L}$, teve a mais alta reatividade, o que explica a diminuição de seu uso médico, praticamente em todo o mundo, embora ainda tenha sido usado no Brasil até pouco tempo atrás. Já o aço F138, o mais utilizado nos implantes ortopédicos no Brasil, teve desempenho regular. Enquanto o aço 5832-9 (categoria definida pela Associação Brasileira de Normas Técnicas), ainda não regularizado para este fim no País, apresentou estabilidade química superior, graças ao alto teor de nitrogênio na sua composição o que o torna mais resistente à corrosão. Este aço foi desenvolvido na Europa e já é produzido no Brasil, porém ainda não está sendo usado como materiais para implante, pois ainda aguarda a regulamentação para o seu uso pela Agência Nacional de Vigilância Sanitária (RODRIGUES, 2004).

A norma ASTM F138, regulamenta que o aço inoxidável para implantes deve ter estrutura austenítica, pois esta estrutura oferece maior resistência à corrosão. Ela pode ser obtida pela adição do níquel que estabiliza a estrutura cúbica de face centrada do ferro e expande o campo da fase austenítica e torna a austenita estável até temperaturas abaixo da temperatura ambiente. Esse tipo de aço é chamado de aço inoxidável austenítico. Ele não é endurecido por tratamento térmico, mas pode ser endurecido por trabalho a frio. Esse grupo de aço inoxidável é não-magnético. O aço inoxidável, passivado ao ar, tem sua passividade destruída por íons cloretos em pontos ou áreas localizados, provocando a corrosão por pites nesses pontos (GENTIL, 1996) que é um tipo de corrosão extraordinariamente localizada, pela qual, em determinados pontos da superfície no material, o meio agressivo consegue quebrar o filme passivo para depois progredir em profundidade. O crescimento dos pites se dá em um processo auto-catalítico e, embora a perda da massa possa ser às vezes insignificante, gerando uma forma de corrosão extremamente insidiosa, já que muitas vezes um pite é suficiente para deixar um equipamento fora de serviço (FICHA TÉCNICA). Devido a esse motivo é preciso aumentar a resistência do aço inoxidável a esse tipo de corrosão, em soluções salinas, para isso adiciona-se molibdênio como elemento de liga ao aço inoxidável, permitindo a formação de uma camada mais resistente (PARK; LAKES, 1992).

Atualmente, a principal aplicação do aço inoxidável é na fixação interna. Sua biocompatibilidade foi provada por muitos anos de implantação humana com êxito. Além disso, demonstra uma boa combinação de resistência mecânica, ductilidade, custo efetivo e facilidade de fabricação. O uso do aço inoxidável em cirurgias ortopédicas abriu uma ampla faixa de novas possibilidades no tratamento de fraturas (DISEGI; ESCHBACH, 2000). 
A liga mais utilizada possui estrutura austenítica da série AISI 316 L normalizada pelas normas ASTM F e F138 (DONACHIE 1998; LEIVAS, 1992). A liga 316 L foi desenvolvida com baixo teor de carbono, justamente porque a sua presença reduz significativamente a resistência à corrosão do material. Foi desenvolvido um processo de refusão a vácuo, diminuindo sensivelmente a presença de inclusões não-metálicas. A liga assim elaborada recebeu o nome de 316 LVM. Uma das desvantagens do aço inoxidável $316 \mathrm{~L}$ é a sua incapacidade de repassivar-se instantaneamente, principalmente quando imerso em fluido humano. Essas ligas também apresentam baixa resistência à fadiga em condições de corrosão em frestas, podendo ser extremamente perigoso para pacientes obesos e que praticam muita atividade física. Devido ao grande número de implantes de quadril que apresentaram falhas por fadiga, levou alguns pesquisadores a questionar a adequação da resistência à corrosão-fadiga do aço inoxidável 316 L. Sendo assim, a tendência é a restrição do seu uso e somente destiná-lo a implantes temporários (ZAVAGLIA, 1993).

As ligas a base de cobalto fundido foram introduzidas em 1936 e tem sido usada deste então pela sua alta resistência e biocompatibilidade. Apresentam propriedades mecânicas variáveis, particularmente resistência à fadiga, principalmente devido à dificuldade de se fundir componentes com granulometria fina, uniforme e ausência de microporosidades. As próteses fundidas de cromo-cobalto tendem a apresentar limite de fadiga inferior ao apresentado pelo aço inoxidável 316 L forjado (SÜRY; SEMLISCH 1978 apud ZAVAGLIA, 1993). Segundo Donachie (1998) as ligas de cobalto-cromo possuem grande resistência à corrosão e boas propriedades mecânicas, porém apresentam grande dificuldade na usinagem dos componentes. As ligas de maior utilização são Co-28Cr-6Mo (F75) e a Co-20Cr-10Ni (F90).

As ligas de titânio combinam excelente compatibilidade, alta resistência estrutural, baixo peso e alta resistência à corrosão. Apresenta como qualidade a sua afinidade com o osso; possibilitando a fixação mecânica através do crescimento do osso adjacente, sem a necessidade de cimento ortopédico. Esse metal apresenta boa resistência à corrosão, porém devido a sua baixa resistência não pode ser utilizado em esferas de implantes de quadril, devido à baixa resistência ao desgaste (DONACHIE, 1998; LEIVAS, 1992). 


\subsubsection{Materiais Cerâmicos}

Kawachi et al., (2000) relata que a utilização das cerâmicas como biomateriais remonta a 1894, quando um médico relatou o uso de gesso $\left(\mathrm{CaSO}_{4} \cdot 1 / 2 \mathrm{H}_{2} \mathrm{O}\right)$ como um possível substituto para ossos. O gesso apresenta uma resistência mecânica muito baixa e é completamente reabsorvido pelo organismo, resultando em uma rápida fragmentação e degradação. Tais propriedades pouco atrativas praticamente excluíram a utilização do gesso como biocerâmica implantável.

Os materiais cerâmicos são usados em aplicações biomédicas porque podem oferecer propriedades desejáveis como biocompatibilidade, dureza e boa resistência mecânica e alguns possuem composição que aceleram a proliferação de ossos (osteocondutores). As principais aplicações biomédicas para as cerâmicas se concentram mais nas áreas de ortopedia (osso artificial, articulação artificial, enchimento ósseo, fixador ósseo), odontologia (raiz de dente artificial) e cardiologia (válvula artificial) (CAMPBELL, 2003).

Os materiais cerâmicos são usados em cirurgia de reconstrução, sendo classificadas em dois grupos: bioinerte e bioativo; cerâmicas bioinertes não tem quase nenhuma interação com o tecido vivo (alumina, zircônia). As cerâmicas bioativas são capazes de aderir ao tecido vivo; vários fosfatos de cálcio e certas composições cerâmicas exibem tais características (VALLET-REGI; GONZÁLEZ-CELLBET, 2004).

A alumina foi à primeira biocerâmica amplamente utilizada clinicamente. Desde 1972, a alumina (tipo $\alpha$ ) de alta densidade e pureza maior que $99,5 \%$ tem sido empregada na fabricação de implantes de quadril devido à resistência à corrosão, à alta resistência ao desgaste, excelentes características tribológicas, baixo coeficiente de atrito e boa biocompatibilidade. A vida útil prevista para mancais similares aos encontrados no quadril carregados com 12,0 kN é de 30 anos. (HENCH, 1993; SAWAKI et al., 1992).

A zircônia vem sendo pesquisada e desenvolvida como biomaterial desde 1969 através do trabalho publicado por Helmer e Driskell na fabricação de esferas de cerâmica para próteses totais de quadril. O interesse na aplicação da zircônia em implantes ortopédicos focaliza-se em suas propriedades mecânicas, ou seja, boa resistência à tração, excelente tenacidade à fratura e comportamento tribológico similar ao da alumina (WREGE, 2000).

De acordo com Zavaglia (1993) as biocerâmicas têm sido empregadas na forma densa e porosa. A quantidade e distribuição de porosidade nos materiais cerâmicos influenciam a resistência, módulo de elasticidade, resistência à oxidação, resistência ao desgaste e outras propriedades importantes. Apesar do aumento da porosidade diminuir a 
resistência mecânica do material isoladamente, a existência de poros com dimensões adequadas podem favorecer o crescimento de tecidos através deles, favorecendo o entrelaçamento do tecido com o implante, aumentando, por conseguinte, a resistência do material in vivo. Na forma macroporosa, os implantes aceleram o processo de cura, já que permitem o crescimento progressivo de colágeno e seguinte mineralização do tecido ósseo através de poros abertos e interconectados.

É conhecido que a osteocondução é quase sempre observada nas cerâmicas, sobretudo quando estas possuem composição e/ou porosidade similares à estrutura óssea (CORNELL et al., 1998).

Desde o surgimento nos anos 80 , as cerâmicas de fosfato de cálcio, especialmente a hidroxiapatita, foram consideradas materiais por excelência para remodelação e reconstrução de defeitos ósseos. Esta preferência se deve principalmente por suas propriedades de biocompatibilidade, bioatividade e osteocondutividade, significando que ao serem implantadas no sítio ósseo, não induzem resposta imunológica; ligando-se diretamente ao tecido ósseo permitindo o crescimento do osso ao longo de sua superfície (LEGEROS, 1991).

Os avanços no uso da cerâmica em articulações artificiais receberam muita atenção, especialmente desde que o lendário golfista Jack Nicklaus recebeu uma prótese de substituição total de quadril de cerâmica-cerâmica em 1999 durante um procedimento experimental. Juntas de quadril de cerâmica-cerâmica receberam aprovação da FDA em 2003. Os materiais cerâmicos são usados como articulações artificiais desde os anos setenta quando produtos de alumina de primeira-geração demonstraram-se muito resistentes relacionados ao metal tradicional e o polietileno. O refinamento na qualidade do material e técnicas de processamento, como também um melhor entendimento do design; cerâmico, conduziu à introdução nos anos oitenta de componentes de alumina de segunda geração com desempenho superior (RABELO, 2011).

Uma das descrições na utilização clínica das biocerâmicas está associada à incerteza na vida dos componentes sob estados complexos de tensão associados ao aparecimento de fissuras. Estas limitações podem ser amenizadas através da utilização das biocerâmicas conjuntamente a outros materiais na obtenção de compósitos (HENCH, 1993). As cerâmicas possuem rigidez muito superior à dos ossos e baixa tenacidade à fratura. As características mecânicas semelhantes aos dos ossos podem ser obtidas somente com o emprego de compósitos (HENCH, 1998; SCHACKELFORD, 1999). 


\subsubsection{Materiais Poliméricos}

Os polímeros ganharam importância na cirurgia ortopédica nos últimos 30 anos, devido a sua estabilidade química e propriedades tribológicas (ZAVAGLIA, 1993).

Nos implantes de quadril, os polímeros são empregados na fabricação de cimentos ósseos, confecção de acetábulos e recentemente, na fabricação de hastes intramedulares. $\mathrm{Na}$ confecção das hastes podem-se utilizar polímeros de fibra de carbono reforçados. Desde 1962, para a confecção de acetábulos é utilizado o polietileno de ultra-alto peso molecular (UHMWPE). O politetrafluoretileno (teflon) também pode ser empregado, mas apresenta desgaste excessivo (HALL et al., 1997; SCHACKELFORD, 1999; KURTZ et al., 1999).

Os problemas apresentados pelo UHMWPE utilizado na fabricação de acetábulos estão associados ao desgaste, com a geração de partículas desgastadas (debris) com tamanhos variando do mícron ao submícron. Pesquisas têm sido realizadas visando aumentar as propriedades mecânicas desse material usando fibras de carbono como reforço (ZAVAGLIA, 1993).

Os polímeros biodegradáveis poli (L-ácido lático) e poli (DL-ácido lático) são materiais com grande variedade de propriedades mecânicas e também com várias taxas de degradação in vivo. As propriedades mecânicas iniciais de produtos fabricados com esses materiais são suficientes para alguns usos em ortopedia. Com o passar do tempo, o produto vai se degradando e o osso vai sendo mais solicitado, antecipando a sua recuperação (ZAVAGLIA, 1993).

Atualmente, as resinas poliuretanas vegetais tem sido um segmento emergente. Algumas dessas resinas são produtos alternativos de polióis e pré-polímeros sintetizados a partir de moléculas derivadas de ácidos graxos vegetais, como a resina poliuretana obtida através da sintetização de óleo vegetal. Esses polímeros poliuretanos apresentam vantagens na processibilidade, flexibilidade na formulação, versatilidade de temperatura de cura, excelentes propriedades estruturais além da ausência da emissão de vapores tóxicos (OHARA et al., 1995). A biocompatibilidade dessas resinas tem apresentado diversos resultados satisfatórios de sua utilização na forma de membrana na regeneração óssea guiada em defeitos ao redor de implantes odontológicos ósseo-integrados em coelhos, nos espaços intra-articular e infra-ósseo no côndilo femoral na forma de cimento odontológico e na câmara anterior dos olhos de camundongos (COSTA et al., 1997; VILARINHO et al., 1996; AZEVEDO et al., 1997). 


\subsubsection{Materiais Compósitos}

Os materiais compósitos são formados através da associação de dois ou mais materiais, dos quais um será a matriz e os outros serão componentes de reforço, o que objetiva a obtenção de propriedades específicas para aplicações em implantes, dependendo dos biomateriais empregados.

Uma das estruturas mais eficientes conhecidas é o corpo humano. Os músculos do corpo humano são um belo exemplo do uso eficiente dos materiais compósitos. Os músculos estão presentes num sistema de camadas que consiste em fibras orientadas com ângulos diferentes e em concentrações diferentes. Este sistema resulta numa estrutura resistente, eficiente, versátil e adaptável sendo capaz de executar tarefas surpreendentes. Os ossos também são um compósito natural que suportam o peso de vários membros do corpo e consiste em fibras de colágeno que são envolvidas e mantidas unidas por meio de uma matriz mineral chamada apatita. O projeto e a fabricação de estruturas que funcionem de modo versátil e eficiente tal como o corpo humano, que é um material compósito natural de alto desempenho, é um grande desafio para os cientistas e engenheiros (SILVESTRE FILHO, 2006).

$\mathrm{Na}$ área médica os compósitos poliméricos reforçados (CPR) são fortes candidatos para uma variedade de aplicações. A finalidade para o uso de materiais compósitos para a área médica é a redução do peso e o prolongamento da durabilidade. Por exemplo: cadeira de rodas, muletas e órteses mais leves apresentam vantagens evidentes para os usuários, assim como os dispositivos de implantes médicos devem ser leves, resistentes, duráveis e biocompatíveis (SILVESTRE FILHO, 2006).

Muitos pesquisadores têm buscado soluções para aplicações dos CPR na artroplastia total de quadril, onde os compósitos poliméricos reforçados com fibra de carbono apresentam uma solução para aplicação em cirurgias ortopédicas na articulação do quadril. A habilidade de customizar as propriedades de resistência e rigidez dos CPR atribui uma vantagem decisiva sobre os materiais convencionais para aplicações em implantes de quadril (SILVESTRE FILHO, 2006).

Outras combinações de materiais também poderão ser utilizados na obtenção de compósitos como plástico, carbono, vidro ou matrizes cerâmicas reforçadas com vários tipos de fibras incluindo carbono, $\mathrm{SiC}$, aço inoxidável, vidro fosfatado e $\mathrm{ZrO}_{2}(\mathrm{HENCH}, 1993)$.

Fortulan (1997) propôs a obtenção de compósitos de cerâmica-cerâmica o uso da zircônia adicionada a matrizes de alumina para propiciar o aumento da tenacidade, desvio de propagação de trincas e aumento da tensão de fratura. 


\section{4- MATERIAIS E MÉTODOS}

Por esta técnica ser ainda inexistente no contexto da ortopedia veterinária, a metodologia do presente trabalho é sugestivo particularmente em relação aos protocolos cirúrgicos na técnica de artroplastia de recapeamento de quadril de cães. Todas as etapas foram conceitualmente desenvolvidas em modelos de ossos de cães confeccionados em resina polimérica obtida a partir de um fêmur canino onde foram desenvolvidos os conceitos da técnica cirúrgica e os protótipos dos ferramentais cirúrgicos necessários para o desenvolvimento desta técnica. Inicialmente foram feitas aquisições das imagens dos objetos do trabalho (fêmur canino, ferramentais cirúrgicos e prótese cirúrgica) em que foram convertidas em arquivos CAD, a partir destes foram gerados cópias em gesso dos ferramentais cirúrgicos desde o guia de furação até a fresa de chanframento e também da prótese cirúrgica de recapeamento através do processo de impressão 3D.

Para a confecção das réplicas femorais para a realização dos testes em bancada foram utilizados moldes de silicone onde posteriormente estes moldes eram preenchidos com resina polimérica tornando-a idêntica ao fêmur natural.

A prótese cirúrgica de recapeamento de quadril de cães foi baseada em modelos de próteses de recapeamento em humanos; o modelo da prótese de recapeamento de quadril de cães para a realização dos testes de assentamento em bancada foi obtido inicialmente através do método de impressão 3D onde posteriormente, foi submetido ao processo de modelagem em silicone para que finalmente, pudesse ser manufaturado em resina polimérica.

É ainda apresentada a sugestão de um ferramental cirúrgico específico para a realização desta técnica propriamente dita, desenvolvido no Departamento de Engenharia Mecânica da EESC-USP, em São Carlos. Também é apresentado o modelo conceitual de prótese cirúrgica de recapeamento de quadril de cães, cujo protótipo foi confeccionado para ser usado com o auxílio do ferramental cirúrgico proposto. O ferramental cirúrgico para artroplastia de recapeamento de quadril de cães é constituído por um guia de alinhamento de furação, uma serra copo, um guia para plainamento da cabeça femoral, uma fresa de topo, uma fresa de chanfro e um verificador de assentamento.

Durante a metodologia deste trabalho, não foram desenvolvidos modelos de próteses cirúrgicas acetabulares considerando neste momento as próteses convencionais já existentes na ortopedia veterinária. 


\section{1- Técnica Conceitual para recapeamento de Quadril de Cães}

A técnica de artroplastia de recapeamento de quadril de cães é descrita neste capítulo em sete etapas como se segue.

\subsubsection{Guia de alinhamento de furação}

A técnica conceitual de artroplastia de recapeamento de quadril de cães inicia através da preparação da extremidade do fêmur. Para a realização desta etapa um dispositivo denominado guia de alinhamento de furação, e manufaturado em material metálico, (Figura 4.1) com diâmetro de 23,0 mm, que reveste a cabeça femoral, é utilizado para a realização de uma pré-furação. Este guia de furação é acoplado à cabeça femoral e alinhado manualmente até que o cirurgião encontre a posição que mais se aproxime do ângulo adequado de furação; o guia metálico pode ser fixado à cabeça femoral através de até quatro parafusos localizados ao redor de sua circunferência. Com o guia acoplado à cabeça do fêmur inicia a pré-furação do osso cortical femoral utilizando uma broca de aço com diâmetro de $2,0 \mathrm{~mm}$, penetrando nesta etapa apenas $5,0 \mathrm{~mm}$, pois a completa furação será realizada em duas fases de furações com diâmetros e profundidades diferentes. A determinação da profundidade feita no osso cortical femoral se dá através de colar de batida montada na respectiva broca de furação. Após a furação inicial com a broca de 2,0 mm, o guia de alinhamento de perfuração é então removido, permanecendo somente a broca acoplada, pois assim, é possível visualizar e verificar se o ângulo de furação está correto e caso esteja, a etapa final de furação pode ser iniciada. Nessa etapa, a broca de 2,0 mm e o guia de furação são retirados, ficando apenas o orifício de $4,0 \mathrm{~mm}$ no guia para realizar a etapa final de furação. A furação final é realizada com uma broca de 4,0 mm de diâmetro alcançando uma profundidade equivalente de $30,0 \mathrm{~mm}$, profundidade esta que também é determinada através de um colar de batida acoplada a broca. 


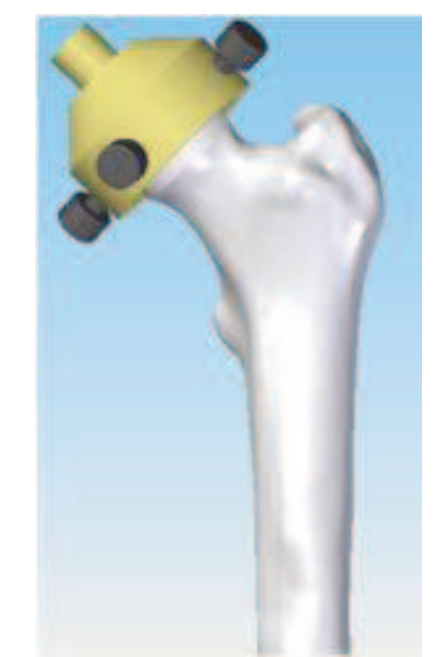

Figura 4.1- Guia de alinhamento de furação da cabeça do fêmur.

\subsubsection{Refilamento da cabeça femoral}

O refilamento da cabeça femoral consiste na modelação da parte da cabeça femoral em um formato cilíndrico. Para realização desta etapa, torna-se necessário o uso de um ferramental denominado de fresa serra copo (Figura 4.2). Para testar esse tipo de ferramenta, foi utilizado um fêmur canino confeccionado em resina em testes de bancada; $O$ modelo em resina tem uma cabeça com diâmetro de 23,0 mm de circunferência que, posteriormente ao refilamento, passa a ter $17,0 \mathrm{~mm}$. Com o auxílio de uma furadeira de baixa rotação e uma fresa serra copo devidamente acoplada e guiada por um pino guia de 4,0 mm de diâmetro que permanece no centro da fresa, é realizado o refilamento cilíndrico da cabeça femoral. O pino guia direciona a fresa copo à medida que esta avança sobre a cabeça femoral. O furo realizado anteriormente na cabeça do fêmur tem uma profundidade de 30,0 mm; para determinar o curso do refilamento, o comprimento do pino-guia é definido e um colar de batida é fixado no pino guia e quando este encosta na face da cabeça femoral fica determinada o final da etapa de refilamento, pois caso haja avanço com a fresa, danos no colo femoral e até mesmo fraturas podem ocorrer. Diferentemente de fêmures humanos, os de animais de um modo geral, em especial os de cães, possuem uma assimetria óssea acentuada. No refilamento realizado em artroplastia de recapeamento em humanos também é utilizado uma fresa copo, porém, não há necessidade de remoção de esquírolas ósseas devido à perfeita conformação da cabeça femoral. Já em animais, especificamente em cães, é necessária remoção de esquírolas ósseas com o auxílio de goivas cirúrgicas para realizar o refilamento com mais precisão. Em animais, esta remoção se torna importante, pois irá 
permitir um encaixe perfeito da prótese cirúrgica de recapeamento femoral após a finalização do preparo da extremidade óssea do fêmur.

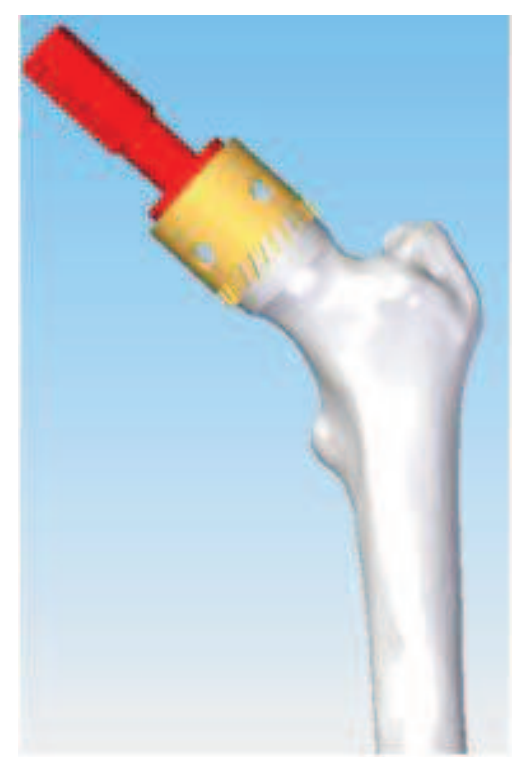

Figura 4.2- Fresa serra copo para refilamento cilíndrico da cabeça femoral.

\subsubsection{Guia para plainamento da cabeça femoral}

Com a cabeça femoral devidamente refilada na forma cilíndrica, a etapa de plainamento da cabeça femoral (superfície) é realizada com o auxílio de um anel metálico inoxidável onde este possui um parafuso que permite seu travamento na parte cilíndrica refilada, ficando exposta somente a parte a ser removida na medida prevista. O parafuso do anel é então apertado e a parte superior da cabeça femoral excedente está pronta para ser resseccionada com o auxílio de uma ferramenta adequada ou até mesmo manualmente com uma grosa convencional. $\mathrm{O}$ anel guia de plainamento da cabeça femoral, já cilíndrico, é ilustrado na Figura 4.3. 


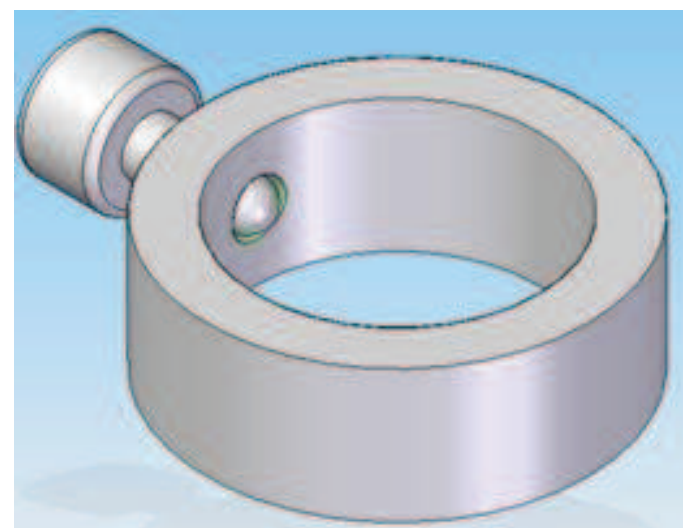

Figura 4.3- Guia para plainamento da cabeça femoral.

\subsubsection{Plainamento da cabeça do fêmur}

A etapa de plainamento da cabeça do fêmur requer a utilização de um ferramental metálico denominado de fresa de topo (Figura 4.4) que por sua vez, é acoplado a uma furadeira de baixa rotação (0-550 RPM). Este ferramental é composto de uma haste (guia) com diâmetro de 4,0 mm e uma lâmina de corte no centro; A Lâmina de corte é fixa permanentemente à haste (guia) devido ao processo de fabricação em um único ferramental, aumentando sua resistência ao corte. O diâmetro da haste metálica que é introduzida no furo para guiar a lâmina de corte tem o mesmo diâmetro referente ao da etapa anterior (guia para plainamento da cabeça femoral). Essa operação deixa a superfície da cabeça femoral totalmente plana. Como medida de segurança, a determinação do término desta etapa se dá quando a haste não consegue avançar mais do que os $30,0 \mathrm{~mm}$ definidos na etapa de furação.

Figura 4.4- Fresa de topo para plainamento cabeça do fêmur. 


\subsubsection{Chanframento da cabeça do fêmur}

Com a cabeça femoral devidamente preparada (cilíndrica e plainada), é então iniciada a etapa de chanframento onde as bordas do cilindro femoral são chanfradas com o auxílio de um ferramental específico denominado de fresa de chanfro (Figura 4.5). Acoplada a uma furadeira de baixa rotação esta ferramenta tem uma haste (guia) e uma lâmina de corte onde, à medida que entra em contato com o tecido ósseo, remove o material na circunferência da cabeça femoral em forma de chanfro. O limite de chanframento é determinado através da haste metálica que penetra no furo existente a uma profundidade máxima de 30,0 mm. A lâmina de chanfrar também é fixa permanentemente à haste metálica; possui corte nos dois sentidos facilitando a remoção do tecido ósseo e reduzindo a força de corte das lâminas durante o processo de chanframento. A etapa de chanframento da cabeça do fêmur tem a finalidade de manter uma perfeita igualdade do perfil da cabeça femoral com a da prótese cirúrgica de recapeamento favorecendo assim um encaixe perfeito. A ferramenta de chanfrar remove cerca de $2,0 \mathrm{~mm}$ de tecido ósseo em toda circunferência em um ângulo de $45^{\circ}$ como visto na Figura 4.5 .

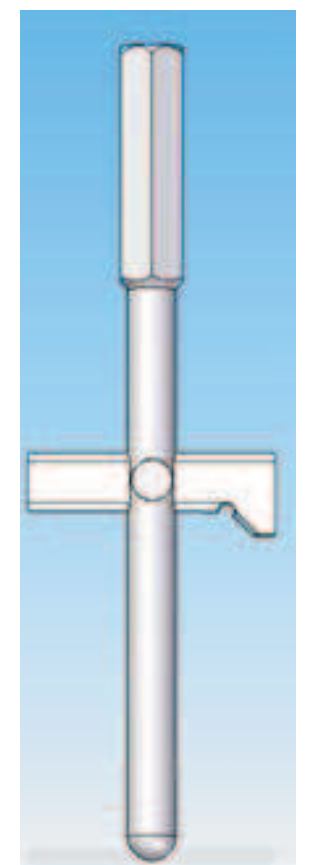

Figura 4.5- Fresa para chanframento da cabeça femoral. 


\subsubsection{Verificação do assentamento}

Para a verificação da modelação completa da cabeça do fêmur em resina, utilizou-se uma réplica da prótese de recapeamento, manufaturada em gesso, através do processo de impressão 3D. Esta réplica foi utilizada em bancada para testar a cabeça femoral, agora cilíndrica, devidamente preparada para o recebimento da prótese cirúrgica. A réplica para demonstração em bancada possui no seu interior, uma haste com diâmetro de 4,0 mm e comprimento referente a $30,0 \mathrm{~mm}$. Para a realização de testes reais, ou seja, quando houver cirurgia em animais, será utilizado um modelo (protótipo) confeccionado em cerâmica, ora em desenvolvimento no Laboratorio de Tribologia e Compósitos da EESC/USP; este também terá uma haste central com as respectivas medidas referente ao modelo confeccionado em gesso. O modelo para verificação de assentamento da prótese cirúrgica de recapeamento de quadril de cães seja para teste em bancada (gesso) ou para testes reais (cerâmica), são idênticos.

\subsection{Assentamento da Prótese Cirúrgica de Recapeamento Femoral}

\subsubsection{Prótese cirúrgica}

A prótese cirúrgica de recapeamento de quadril de cães tanto a réplica em gesso, como a real em cerâmica, é formada por uma parte hiperesférica (cabeça) e por uma parte cilíndrica (pino). Essa prótese é assentada na extremidade do fêmur cujo furo guia o pino da prótese cirúrgica ao ser encaixado; simultaneamente, haverá o contato da extremidade proximal do fêmur com a parte interna da prótese cirúrgica, ou seja, a prótese cirúrgica e a cabeça do fêmur possuem o mesmo perfil que permite haver um assentamento perfeito. Para demonstração em teste de bancada, a prótese cirúrgica de recapeamento de quadril de cães foi manufaturada em gesso através de processo de impressão 3D. Para situações reais, ou seja, em cirurgias de recapeamento de quadril de cães in vivo, a prótese será confeccionada em material cerâmico; neste caso o assentamento terá uma tolerância de deslizamento entre o pino da prótese e o furo na cabeça do fêmur; a prótese cirúrgica terá 
em sua superfície uma camada porosa com fatores de crescimento ósseo que irá proporcionar a sua integração e fixação permanente ao osso.

\subsubsection{Fixação biológica da prótese cirúrgica}

A fixação biológica da prótese cirúrgica de recapeamento de quadril de cães, somente será possível de ser observada em cirurgias reais onde através de exames histopatológicos tornar-se há possível a visualização deste processo. Já no teste de bancada, forma pela qual este trabalho é conceitualmente apresentado, não é possível demonstrar esta técnica, sendo apenas possível a sua discussão de forma didática. Os poros existentes na superfície da prótese cirúrgica (definitiva) a ser manufaturada futuramente, estas são associados a fatores de crescimento ósseo que permitem a aceleração do crescimento ósseo significativo favorecendo assim, o seu ancoramento devido à fixação biológica que ocorre entre os materiais presentes no componente protético com o tecido ósseo.

Dentre os materiais que estimulam o crescimento ósseo conhecidos como bioativos, os mais utilizados são a hidroxiapatita, $\left(\mathrm{Ca}_{10}\left(\mathrm{PO}_{4}\right)_{6}(\mathrm{OH})_{2}\right)$, o biovidro e os compostos a base de fosfato de cálcio. São eles que proporcionam ligações de natureza química entre o material da prótese cirúrgica e o tecido ósseo, fato este que promove a osteointegração propriamente dita, com maior rapidez. Esses materiais bioativos, promovem uma resposta biológica específica na interface tecido-material implantado que resultará na união entre o tecido ósseo e a prótese cirúrgica (HENCH, 1972), ou seja, o seu ancoramento. Em função da similaridade química entre os materiais bioativos e a parte mineral óssea, os tecidos ósseos se ligam a estes materiais, permitindo a osteocondução através do recobrimento por células ósseas (CAMILO, 2006). 


\subsubsection{Verificação final do assentamento da prótese cirúrgica}

Após o término da técnica cirúrgica seja ela em teste de bancada ou em cirurgias reais, torna-se necessário uma verificação manual para garantir que a prótese cirúrgica de recapeamento esteja adequadamente fixada à cabeça femoral. A verificação é feita com o auxílio das mãos onde o cirurgião segura firmemente a região do colo femoral com a mão esquerda, e com a mão direita realiza movimentos de rotação interno e externo, e também movimentos de tração verificando definitivamente se a tolerância de deslizamento existente permite sua correta fixação.

\subsubsection{Estabilização da prótese cirúrgica}

A técnica de artroplastia de recapeamento da cabeça femoral quando em cirurgias reais, necessitará de uma prótese acetabular para uma melhor estabilização, pois geralmente em casos de patologias articulares degenerativas como a displasia coxofemoral, a fossa acetabular perde a camada fibrocartilaginosa a qual serve de amortecimento durante o movimento.

Em cirurgias reais, a prótese cirúrgica de recapeamento (femoral) depois do devido assentamento, será encaixada a uma prótese acetabular onde desta forma ocorrerá uma estabilização mecânica da articulação protética devido à presença de estruturas na prótese acetabular que irá manter-se fixada a prótese femoral.

Outro mecanismo que ajudará coadjuvantemente no processo de estabilização da articulação protética em cirurgias reais será através da musculatura periarticular de forma parcial, pois terá uma segurança maior através do encaixe mecânico das próteses (femoral e acetabular).

Em testes de bancada, a estabilização da prótese é apenas demonstrativa onde é encaixada ao acetábulo; em cirurgia real, quando a fossa acetabular apresenta patologia óssea degenerativa, há a necessidade de implantação de um acetábulo, pois, a prótese cirúrgica de recapeamento poderá se soltar e conseqüentemente gerar instabilidade e dor no animal submetido a este procedimento cirúrgico. O acetábulo, neste caso, diferentemente das atuais próteses cirúrgicas de recapeamento, poderá ter sua fixação de forma idêntica a 
do recapeamento femoral, ou seja, também possuirá em toda sua superfície camadas porosas com fatores de crescimento ósseo, onde no devido tempo, promoverá a osteointegração e conseqüentemente sua fixação permanente. 


\section{5- RESULTADOS}

Neste item, através de figuras ilustrativas, é demonstrada toda a seqüência das etapas do desenvolvimento conceitual e realização simulada de um recapeamento de quadril em bancada de laboratório, utilizando modelos em gesso, manufaturados através do processo de impressão 3D.

O desenvolvimento de todo o ferramental cirúrgico mostrado neste item, desde o guia de furação até a fresa de chanframento bem como o modelo de prótese de recapeamento de cão, foi realizado pela equipe de projeto do LTC-EESC-USP, sob a coordenação do orientador deste trabalho; os desenhos e a construção dos modelos em gesso através do processo de impressão 3D foram realizados por Renan Botega, nas dependências do LTC-EESC-USP.

A Figura 5.1 ilustra um fêmur de cão de porte médio (01) obtido a partir de um cadáver que foi utilizado para reproduzir uma réplica (02) em resina, idêntica ao original. A réplica foi reproduzida através da moldagem em moldes de silicone. Esta é a réplica que servirá de modelo para a simulação de recapeamento de quadril de cão em bancada.
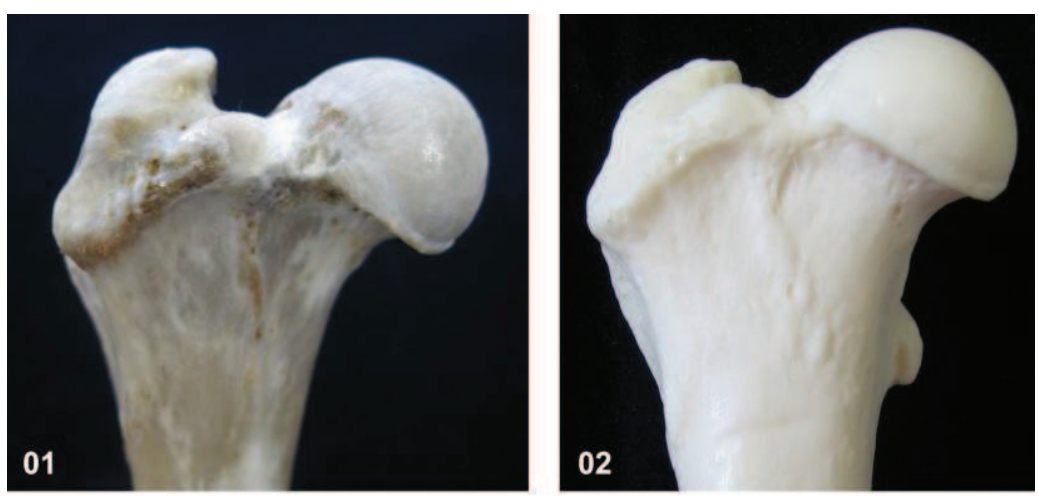

Fonte: LTC-EESCUSP (2011)

Figura 5.1- Fêmur de cão e réplica em resina.

A Figura 5.2 mostra o guia (01) para a furação da cabeça do fêmur do cão (modelo em resina). Esse guia permite o posicionamento da broca relativamente ao ângulo de $145,0^{\circ}$. A furação da cabeça do fêmur é a primeira etapa da cirurgia de recapeamento de quadril, relativamente ao modelamento do osso. A furação da cabeça do fêmur pode ocorrer em até três etapas, utilizando em cada etapa subseqüente, brocas com diâmetro crescente até o diâmetro final de 4,0 mm e furação com profundidade de $30,0 \mathrm{~mm}$. 

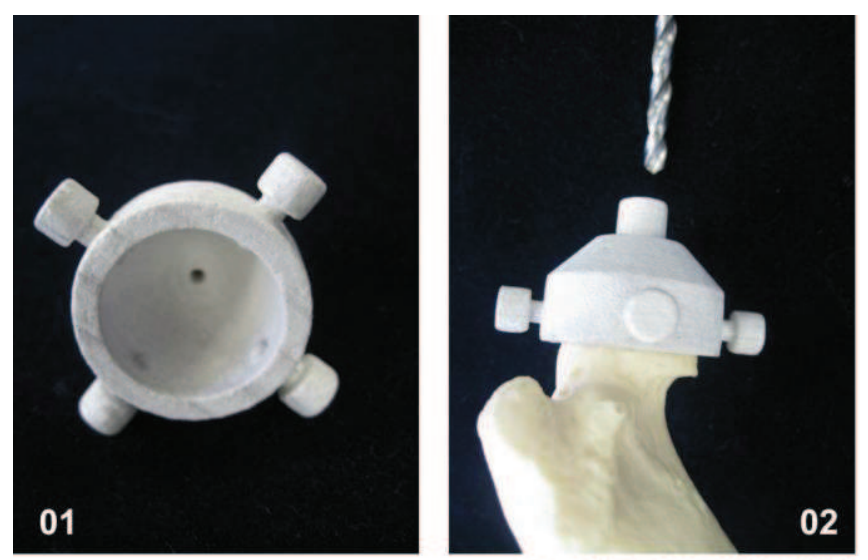

Fonte: LTC-EESCUSP (2011)

Figura 5.2- Furação e guia de furação da cabeça do fêmur de cão.

Foi experimentada uma furação da cabeça femoral (réplica) em bancada de laboratório no próprio guia de furação (protótipo), o que garantiu uma furação ideal com alinhamento satisfatório.

Uma vez realizada a furação final, passa-se ao refilamento cilíndrico da cabeça femoral como ilustra a Figura 5.3. Para tal utiliza-se uma fresa copo (01) devidamente projetado para tal operação

A operação de refilamento cilíndrico (02), na Figura 5.3, foi realizada também em bancada. A finalidade dessa operação é deixar a cabeça femoral na forma cilíndrica, na mesma medida que a parte interna, cilíndrica, da prótese cirúrgica de recapeamento.
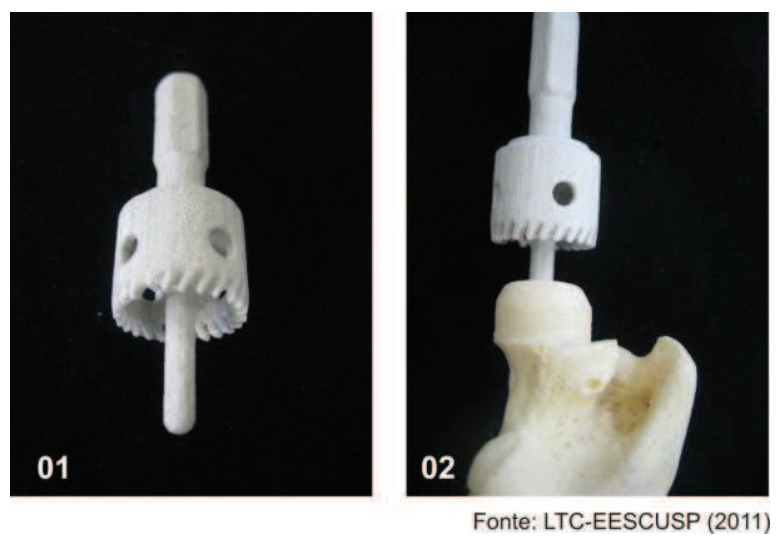

Figura 5.3- Refilamento cilíndrico da cabeça femoral de cão com fresa (serra) Copo.

O refilamento cilíndrico deixa a extremidade do osso para ser aplainada e faceada. Isso é feito utilizando uma fresa reta para faceamento (01) conforme ilustra a Figura 5.4. Esse faceamento é necessário para estabelecer o comprimento definitivo da parte cilíndrica refilada, para o assentamento correto da prótese cirúrgica de recapeamento. A face aplainada tem sua medida ou posição referenciada através da profundidade do furo de $4,0 \mathrm{x}$ 
$30,0 \mathrm{~mm}$ realizado anteriormente. Para garantir o perfeito perpendicularismo da face aplainada com a superfície cilíndrica, pode-se utilizar um anel guia de faceamento.
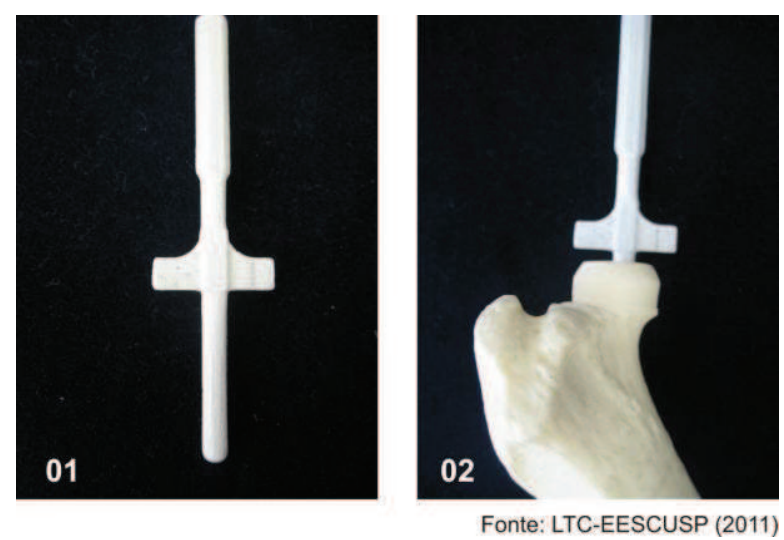

Figura 5.4- Fresa reta para o faceamento da cabeça femoral (cilíndrica) de cão.

Para garantir o perfeito assentamento da prótese cirúrgica de recapeamento de quadril de cães e minimizar os efeitos de bordas na extremidade cilíndrica do fêmur, é realizado o chanframento à $45^{\circ}$ dessa borda cilíndrica (02), conforme mostra a Figura 5.5, utilizando uma fresa biselada, na angulação desejada (01).
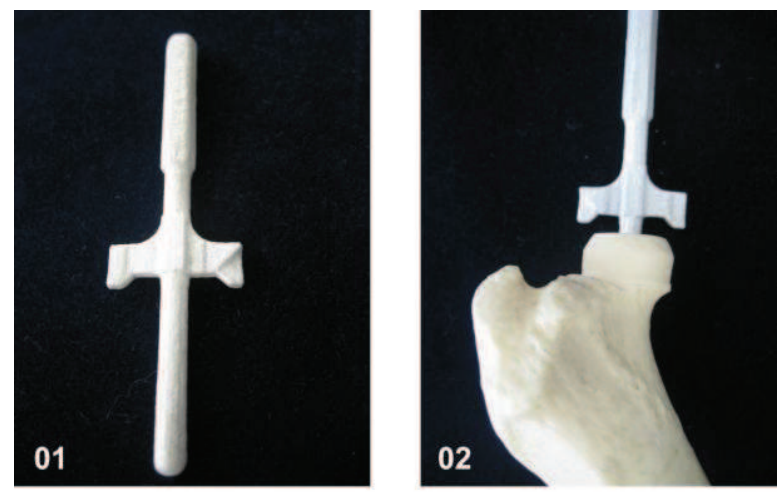

Fonte: LTC-EESCUSP (2011)

Figura 5.5- Chanframento das bordas da superfície cilíndrica com fresa de topo biselada.

O perfil ora obtido para a cabeça do fêmur, ou seja: furado; cilíndrico; faceado; chanfrado, condiz com o perfil interno da prótese de recapeamento de quadril para seu perfeito assentamento. A Figura 5.6 ilustra o fêmur de cão após a realização de todas as operações de conformação da cabeça femoral que antecedem o assentamento de prótese cirúrgica de recapeamento de quadril. 

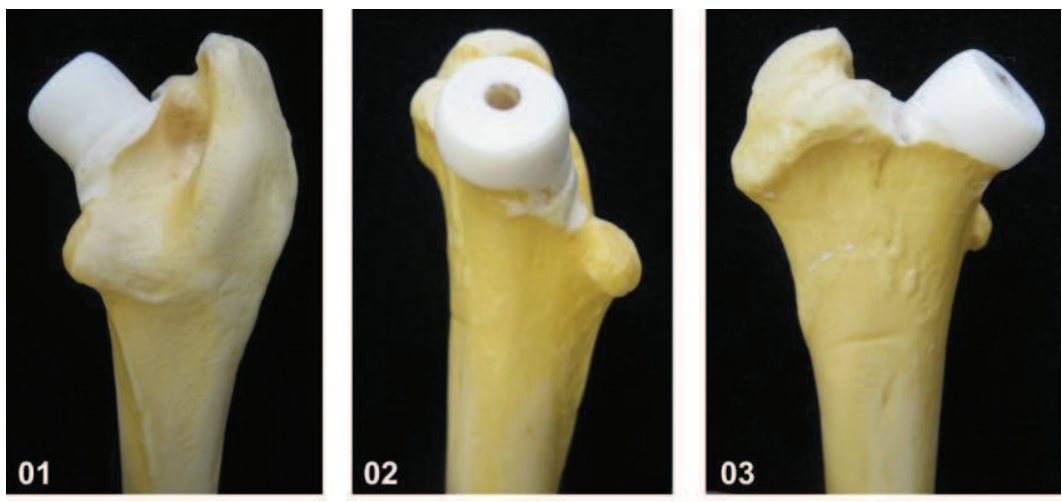

Fonte: LTC-EESCUSP (2011)

Figura 5.6- Perfil final da cabeça do fêmur de cão para a colocação da prótese de recapeamento.

Uma vez preparada à cabeça do fêmur, pode-se simular o assentamento da prótese cirúrgica de quadril de cão conforme ilustra a Figura 5.7. A prótese cirúrgica de recapeamento (01-03) foi confeccionada também em gesso através do processo de impressão 3D e serviu de modelo ou réplica para ilustrar conceitualmente esta etapa de recapeamento de quadril de cão.
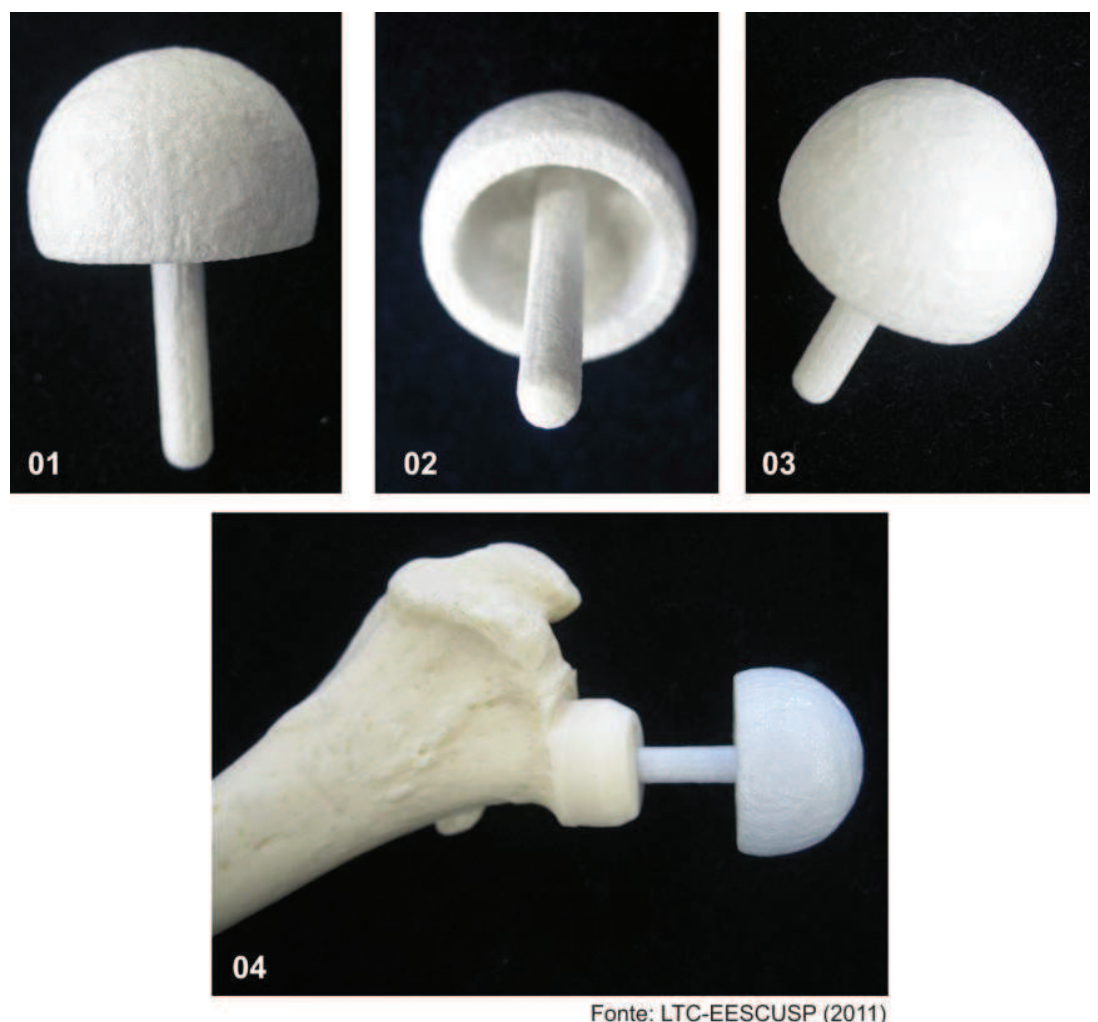

Figura 5.7- Prótese de recapeamento de quadril de cão (01-03). Simulação do assentamento da prótese (04).

As Figuras 5.8 e 5.9 ilustram a finalização da "cirurgia de bancada" realizada com modelos e réplicas de resina e gesso, com a finalidade de mostrar comparativamente com o 
modelo original (natural) que será possível a realizar essa cirurgia in vivo, em um futuro próximo, com próteses cirúrgicas de cerâmica e ferramental adequado, seguindo as simulações mostradas neste item.
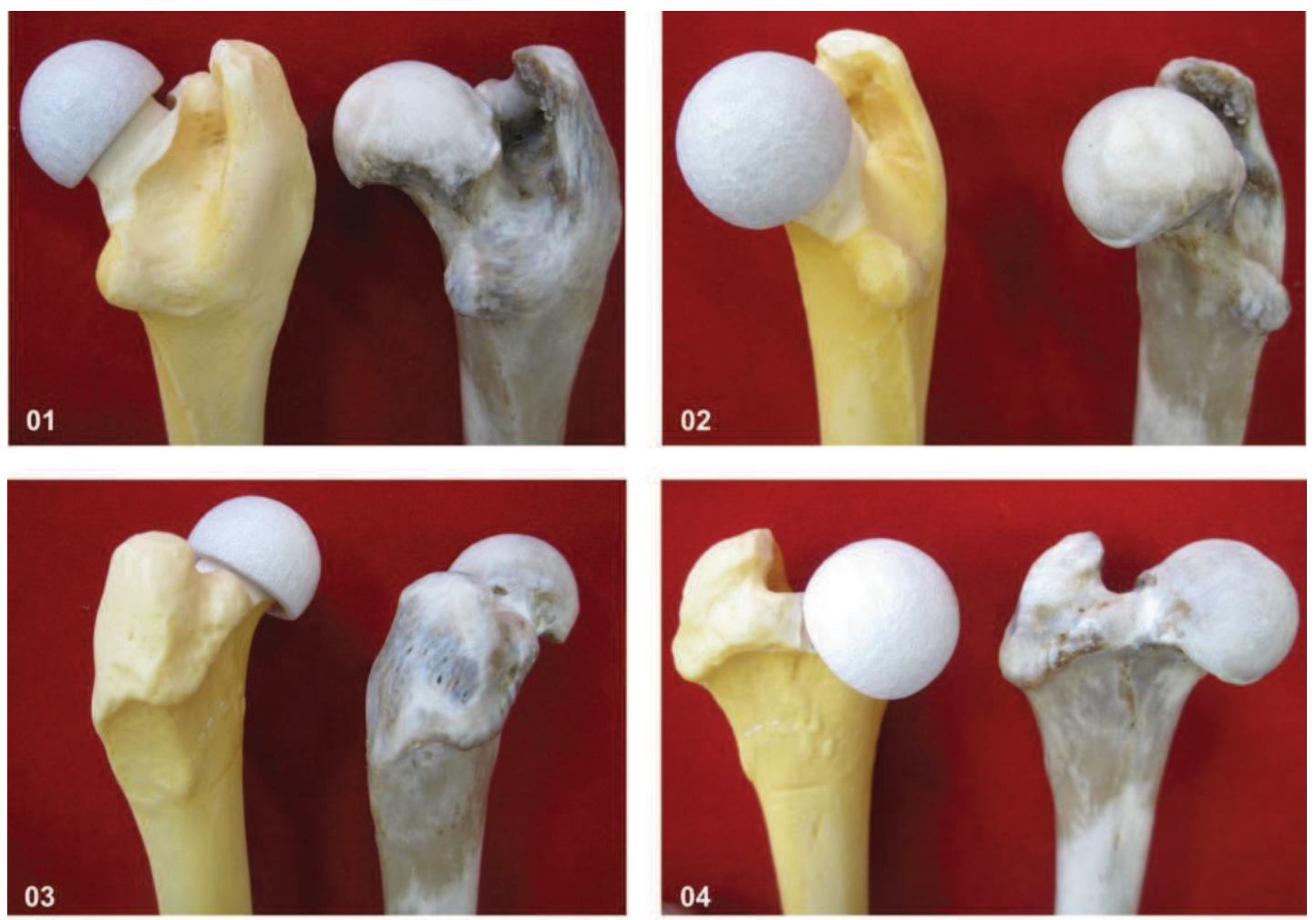

Fonte: LTC-EESCUSP (2011)

Figura 5.8- Etapa final do recapeamento de quadril de cão. Comparação com o modelo original (natural).
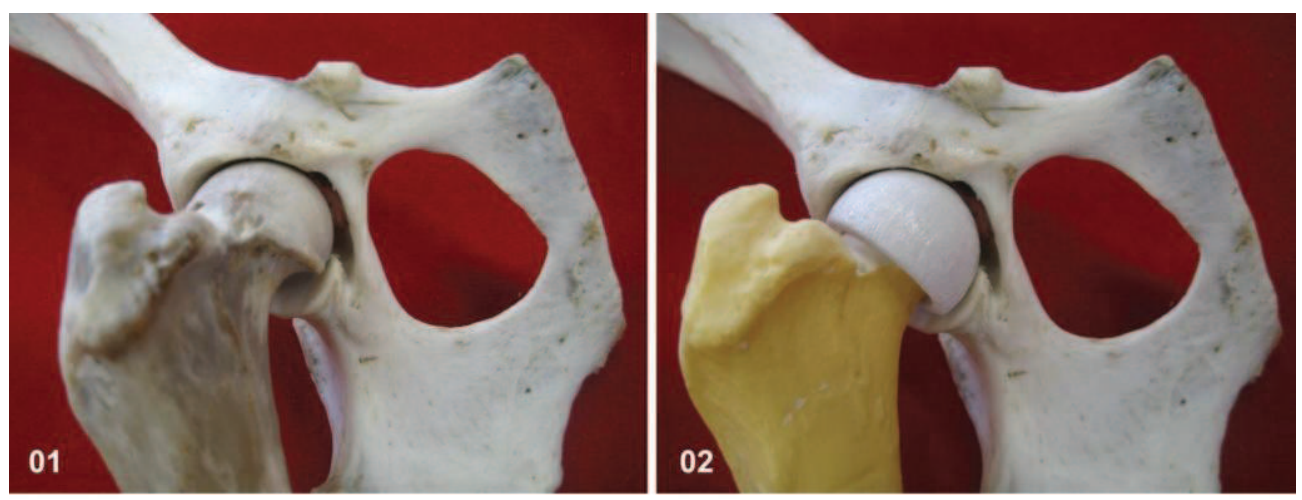

Fonte: LTC-EESCUSP (2011)

Figura 5.9- Finalização da cirurgia conceitual de bancada de recapeamento de quadril de cão. 


\section{6- DISCUSSÃO}

A partir de estudos sobre artroplastia de recapeamento de quadril em humanos (Resurfacing), foram desenvolvidos protocolos cirúrgicos conceituais de recapeamento de quadril em cães procedimento este, que foi realizado em bancada de laboratório para realização dos testes necessários e para a realização deste trabalho, tornou-se necessário o desenvolvimento de um ferramental cirúrgico específico para a realização de todas as etapas deste procedimento cirúrgico experimental, sendo estes desenvolvidos em máquina operatriz.

A artroplastia de quadril em humanos foi desenvolvida com a finalidade de restabelecer a função articular e também para proporcionar o alívio da dor do paciente (KUSHIYAMA; ISHIDA; TRIGUEIRO, 2011).

Em contraste na Medicina Veterinária é inexistente a descrição da técnica de recapeamento de quadril em cães e a técnica mais utilizada na atualidade é a artroplastia total com implantes metálicos.

Algumas patologias como displasia coxofemoral, necrose asséptica da cabeça do fêmur, artrite e artrose levam os animais a perda da função do membro afetado sendo necessária a intervenção cirúrgica através do médico veterinário (cirurgião) para a colocação de uma prótese cirúrgica total na articulação coxofemoral uni ou bilateralmente.

O desenvolvimento da técnica conceitual de artroplastia de recapeamento de quadril de cães, através de testes experimentais em bancada de laboratório foi de suma importância, pois todos os componentes necessários para a realização desta técnica cirúrgica são manipulados possibilitando um contato direto e facilitando a dinâmica do procedimento cirúrgico propriamente dito.

No ato cirúrgico (in vivo) torna difícil para o cirurgião identificar a posição correta de furação para isto, com o auxilio de um guia de furação em testes de bancada, torna possível uma prévia visualização de como é feito o alinhamento do dispositivo, seu travamento e utilização para furação, ou seja, torna possível um prognóstico de como será esta furação da cabeça femoral em uma cirurgia real.

Uma vez que é possível realizar a furação na cabeça do fêmur (réplica) em um ângulo próximo do ideal, este irá determinar o sucesso da colocação do implante em um posicionamento adequado.

Foi possível realizar um refilamento adequado em teste de bancada de laboratório onde não houve formação de esquírolas mesmo se tratando de uma réplica confeccionada em resina polimérica. 
$\mathrm{Na}$ ortopedia veterinária, em cirurgias reais, as técnicas cirúrgicas adeptas para correções de patologias articulares de quadril de cães onde o uso de próteses totais se torna necessários, envolvem apenas a etapa de ressecção da cabeça e colo femoral para que a prótese cirúrgica possa ser encaixada no canal femoral, por outro lado, esta técnica conceitual de artroplastia de recapeamento de quadril de cães em bancada, por envolver várias etapas com ferramentais cirúrgicos apropriados para cada qual, torna esta técnica cirúrgica complexa, sendo assim, possibilita um treinamento prévio para que quando houver cirurgias reais, o cirurgião poderá manusear os ferramentais cirúrgicos junto às réplicas femorais de cães; quando em cirurgias reais, o cirurgião deverá ter cuidado durante o procedimento cirúrgico, pois caso haja negligência e estes ferramentais danificarem alguma estrutura periarticular importante como musculaturas e nervo ciático, levará novamente ao comprometimento da articulação coxofemoral já afetada.

O desenvolvimento do ferramental para faceamento da cabeça femoral teve êxito e sua aplicação tornou-se viável e segura, pois, através de uma furadeira de baixa rotação, é permitido o controle de uma rotação desejada e promoveu até mesmo uma segurança maior com o auxílio de um dispositivo denominado guia de faceamento que mesmo em cirurgias reais, mesmo que o cirurgião avance com a fresa, danos maiores serão evitados através do próprio guia de faceamento e também através da haste (guia) presente na fresa de topo.

Foi possível verificar em bancada um assentamento satisfatório da prótese cirúrgica de recapeamento devido ao fato de um perfeito refilamento, faceamento e chanframento da cabeça femoral onde o ferramental mostrou-se eficiente e permitiu um perfil ideal entre a cabeça femoral e a prótese cirúrgica.

A prótese cirúrgica de recapeamento de quadril de cães obtidas através de impressão 3D serviu de modelo para reproduzir a replica para possíveis testes; o assentamento da prótese cirúrgica foi compatível com o perfil facial da cabeça femoral com a parte interna da prótese cirúrgica (réplica).

Através da técnica conceitual de artroplastia de recapeamento de quadril de cães desenvolvida em bancada de laboratório, será permitido que em cirurgias reais possivelmente realizadas em um futuro próximo com próteses cirúrgicas confeccionadas em cerâmica e ferramental cirúrgico adequado, os cirurgiões antes mesmo de realizar cirurgias deste porte, poderão verificar a complexidade das peças anatômicas (quadril e fêmur) juntamente aos ferramentais apropriados para que durante a manipulação, haja o reconhecimento tridimensional do osso a ser operado.

Outro ponto fundamental deste trabalho, diz respeito sobre a vantagem desta cirurgia onde ao contrário de cirurgias convencionais, onde há uma ressecção total da cabeça e colo femoral, nesta haverá somente uma ressecção mínima da cabeça femoral que permitirá 
melhor estabilização da prótese cirúrgica de recapeamento bem como na diminuição do tempo de cirurgia.

A fabricação do ferramental cirúrgico foi de extrema importância, pois garantiu os resultados deste trabalho que por sua vez apresentou resultados satisfatórios conferindo compatibilidade entre as medidas estabelecidas durante todo o projeto até os resultados esperados finais (testes em bancada).

As principais complicações observadas durante a execução dos testes em bancada foi à realização de um furo preciso na etapa de furação equivalente a um ângulo de 135$140^{\circ}$ graus, pois de fato, os ajustes foram realizados manualmente; para um ajuste próximo do ideal, foi desenvolvido um guia de alinhamento de furação que possibilitou uma visualização melhor do ângulo de furação esperado.

Outra complicação observada durante o desenvolvimento deste trabalho diz respeito à fabricação das fresas de topo e de chanfro, pois como foram projetadas e fabricadas em máquina operatriz, requereu tempo prolongado para sua fabricação e habilidade por parte do operador para que erros pudessem ser evitados, pois caso ocorressem, por se tratar de ferramentais confeccionados em única peça, todo processo teria que ser repetido novamente atrasando ainda mais os testes de bancada.

Os materiais utilizados nos dias de hoje em implantes suprem em partes as necessidades exigidas. Assim como características benéficas estes materiais possuem algumas particularidades indesejáveis que podem trazer desconforto e transtornos ao paciente. Diversos autores citam como exemplo de infortúnios como metalose, rigidez excessiva do material em relação ao osso, curto espaço de tempo para manutenção e substituição (LATHAM; GOSWANI, 2004), soltura dos componentes (FREITAS et al., 1997; DRUMOND et al., 1999), afrouxamento mecânico (EATON; CAPELLO, 1983) entre outros. Sendo assim, devido ao processo de melhoria contínuo em pesquisas e o surgimento de novos materiais para implantes que possam cumprir de maneira adequada às funções da parte substituída e a estrutura implantada deve ter um desempenho satisfatório, apresentando biocompatibilidade, resistência dentre outras características (KATTI, 2004).

De acordo com Minto et al., (2008) os implantes de artroplastia para cães consiste em cúpula de polietileno de alta densidade e de componente femoral em aço inoxidável ou titânio. Também são utilizados outros materiais como liga metálica de cromo-cobalto (OLMSTEAD et al., 1983; DE YOUNG et al., 1992; WALLACE; OLMSTEAD, 1995). Existem modelos cimentados, cujos componentes apresentam uma superfície porosa que permite a integração dos mesmos ao tecido ósseo (IDO et al., 1993; OTSUKA et al., 1994); entretanto, os implantes cimentados são os mais utilizados na Medicina Veterinária (OLMSTEAD et al., 1981; OLMSTEAD; SIDEBOTHAM, 1991; MONTGOMERY et al., 1992; REMEDIOS; FRIES, 1995). 


\section{7- CONCLUSÃO}

Com base nos resultados obtidos no presente trabalho, sob a metodologia aplicada, pode-se concluir que a técnica conceitual de artroplastia de recapeamento de quadril de cães é exeqüível e proporcionou resultados satisfatórios no que diz respeito aos procedimentos práticos de execução em teste de bancada, além disso, todo procedimento realizado desde a manipulação dos modelos de ossos confeccionados em resina polimérica juntamente ao ferramental cirúrgico específico, permitiu um planejamento para cirurgias reais em um futuro próximo.

O ferramental cirúrgico desenvolvido no LTC-EESC-USP para a realização da técnica cirúrgica conceitual de recapeamento de quadril de cães em teste de bancada mostrou-se eficiente e versátil frente à morfologia e composição das réplicas de fêmures de cães utilizados, ou seja, tornou-se possível a realização de todas as etapas em todas as réplicas confeccionadas em resina polimérica.

A etapa final do recapeamento de quadril de cão mostrou-se correlação fidedigna entre todas as medidas desde a etapa de furação da cabeça do fêmur até o assentamento final da prótese de recapeamento.

O desenvolvimento deste trabalho auxilia na futura conquista de melhor qualidade de vidados animais necessitados de artroplastia de recapeamento de quadril, tem seu conceito baseado na redução de custo e facilitação de abordagem cirurgica que tornará a técnica acessível a uma maior parcela da população.

Sendo assim, é importante salientar que este trabalho eleva os animais a nível de objeto de estudo, não como cobaias e sim como parceiros na tentativa de descobertas de possíveis melhorias para problemas humanos. 


\section{8-SUGESTÕES PARA TRABALHOS FUTUROS}

A seguir são apresentadas algumas sugestões para trabalhos futuros que complementariam o trabalho feito nessa dissertação ou que podem vir a melhorar o desempenho dos itens aqui descritos. São eles:

- Na etapa de furação da cabeça femoral, para uma correta furação em um ângulo próximo de 135 a $145^{\circ}$ graus o desenvolvimento de um goniômetro com dispositivo de fixação ao colo femoral permitindo uma furação direta no ângulo respectivo tornando esta etapa prática e eficaz.

- Como as fresas de topo e de chanfro foram confeccionadas em peças únicas é sugerido que o desenvolvimento dos ferramentais respectivos seja confeccionado em duas etapas distintas, ou seja, que possuam uma haste única permitindo somente que haja a troca de lâminas caso estas estejam danificadas.

- Sabendo que atualmente nos EUA pacientes humanos portadores de patologias articulares degenerativas de quadril submetidas a procedimentos cirúrgicos, onde o uso de próteses cirúrgicas metálicas se torna necessária, apresentam problemas relacionados à metalose devido a liberação de partículas metálicas na corrente sanguínea, são discutidos e questionados por órgãos competentes (FDA) nos dias de hoje e com base nestas informações, é sugerido o desenvolvimento de uma prótese cirúrgica de recapeamento de quadril de cães confeccionada em cerâmica porosa para implantações futuras já que este é totalmente biocompatível. 


\section{REFERÊNCIAS}

ABUD, F. (2010). Articulação sinovial. Disponível em:<http://fjabud.blogspot.com>. Acesso em: 2 dez. 2010.

ADAMS, D.; QUIGLEY, S. (2005). Hip resurfacing: past, present and future. Journal of Orthopaedic Nursing, Amsterdam, v. 9, n. 2, p. 87-94, May.

AGÊNCIA NACIONAL DE VIGILÂNCIA SANITÁRIA. (2004). Noticias da Anvisa: fórum discutirá segurança de produtos para ortopedia. Disponível

em:<http://www.anvisa.gov.br/DIVULGA/noticias/2004/290104.htm>. Acesso em: 14 fev. 2011.

ALBUQUERQUE, H.P.C.; VIDAL, P.C. (1996). Prótese total de quadril. Revista Brasileira de Ortopedia, Belo Horizonte, v. 31, n. 9, p. 777-780, set.

(1997). Prótese total de quadril: revisão dos conceitos atuais. Revista Brasileira de Ortopedia, Belo Horizonte, v. 30, n. 4, p. 245-248, abr.

ALMEIDA, A.E.R.F.; ALMEIDA, Z.M.O.F. (2010). Instrumentos cirúrgicos. Disponível em:<http://wwwscribd.com/doc/7262739/instrumentos-cirurgicos>. Acesso em: 10 dez. 2010.

ALVES, H.L.R.; BERGMANN, C.P.; STAINER, D. (2011). Avaliação da viabilidade de fabricação de componente em cerâmica avançada aplicado como cabeça femoral em próteses de quadril. Disponível em:<http://www.ufrgs.br/propesq/livro2/artigo_hugo.htm>. Acesso em: 20 dez. 2011.

AMSTUTZ, H.C.; GRIGORIS, P. (1996). Metal on metal bearing in hip arthroplasty. ClinICAL Orthopaedics, Philadelphia, v.329, Suppl., p.S11-S33.

AMSTUTZ, H.C.; GRIGORIS, P.; DOREY, F.J. (1998). Evolution and future of surface replacement of the hip. Journal of Orthopaedic Science, Berlim, v. 3, n. 3, p. 169-186.

AMSTUTZ, H.C. et al. (1988). Survival analysis of T-28 hip arthroplasty with clinical implications. Orthopedic Clinics of North America, Philadelphia, v. 19, n. 3, p. 491-503, July.

AMSTUTZ, H.C. et al. (2004). Metal on metal hybrid surface arthroplasty: twoo to six-year follow-up study. Journal of Bone and Joint Surgery, London, v. 86, n. 1, p. 28-39, Jan.

AMSTUTZ, H.C. et al. (2006). Metal-on-metal hybrid surface arthroplasty: surgical technique. Journal of Bone and Joint Surgery, London, v. 8, p. 234-249.

ARAÚJO, T.L; COUTO, A. A. (2003). Estudo do aço inoxidável aplicado como implante ortopédico. Disponível

em:<http://www.mackenzie.br/fileadmin/Graduacao/EE/Revista_on_line/aco_inoxidavel.pdf.> . Acesso em: 10 fev. 2011.

ARNOCZKY, S.P.; TORZILLI, P.A. (1981). Biomechanical analysis of forces acting about the canine hip. American Journal of Veterinary Research, Chicago, v. 42, n. 9, p. 15811585,Sept.

AUGUST, A.C.; ALDAM, C.H.; PYNSENT, P.B. (1986). The McKee-Farrar hip arthroplasty. Journal of Bone and Joint Surgery, London, v. 68-B, n. 4, p. 520-527, Aug. 
AZEVEDO, C.R.F.; HIPPERT JR., E. (2002). Análise de falhas de implantes cirúrgicos no Brasil: a necessidade de uma regulamentação adequada. Caderno de Saúde Pública, Rio de Janeiro, v. 18, n. 5, p. 1347-1358.

AZEVEDO, P.E.S.F. (1997). Uso da membrana de polímero de mamona em regeneração óssea guiada em defeitos ao redor de implantes ósseo integrado. Revista Brasileira de Implantodontia, n. 6, p. 8-26.

BAUMER. (2011). Ortopedia implante e instrumentais. Disponível em:<http://www.baumer.com.br/Ortopedia/Portugues/detProdutolmgGrande.php?codProduto =146\&imagem=1>. Acesso em: 16 mar. 2011.

BEAULÉ, P.E. et al. (2004). Risk factors affecting outcome of metal-on-metal surface arthroplasty of the hip. Clinical Orthopaedics, Philadelphia, v. 418, p. 87-93.

BERZON, J.L. et al. (1980). A Restrospective study of the effi cacy of femoral and neck excisions in 94 dogs and cats. Veterinary Surgery, Malden, v. 9, n. 3, p. 88-92, July.

BIDERMAN, I. (2011). EUA alertam para falta de segurança de prótese de quadril. Disponível em:<http://www1.folha.uol.com.br/equilibrioesaude/921686-eua-alertam-parafalta-de-seguranca-de-protese-de-quadril.shtml>. Acesso em: 5 jul. 2011.

BIOMEDTRIX (2010). Product catalog. Disponível em:<http://www.biomedtrix.com/catalog_web.pdf>. Acesso em: 20 June 2010.

BOSCHI, A.O. (1995). O Que é necessário para um material possa ser considerado biomaterial. In: CONGRESSO ANUAL DA ASSOCIAÇÃO BRASILEIRA DE MATALURGIA E MATERIAS, 50., 1995, São Pedro. Anais... São Pedro: ABM. v.6, p. 43-53.

BRAKOULIAS, V. (2010). História da ortopedia. Disponível em:<http://www.dpoltda.com.br/historia3.htm>. Acesso em: 8 dez. 2010.

BRASMED (2011). Broca ortopédica. Disponível em:<http://www.brasmed.com. br/mostra.asp?clie=15\&cat=2\&c=\&hr=\&rtd=78hje\&j=\&idped=1 $34 \& p=1116526 \&$ idpart $=\& h j=34545354353 \& l f=d o 0234 \& l=\& e=12312 \& g e r=354 \&$ set $=1 \&$ org $=r t f$ 4\&idprod=515>. Acesso em: 12 mar. 2011.

(2011). Caixa ortopédica de prótese de quadril ws. Disponível em: $<$ http://brasmed.com.br/mostra. asp? $\mathrm{clie}=4 \&$ cat $=2 \& \mathrm{c}=\& \mathrm{hr}=\& \mathrm{rtd}=78 \mathrm{hje} \& \mathrm{j}=$ \&idped $=134 \& \mathrm{p}=$ 1109248\&idpart=\&hj=34545354353\&lf=doo234\&l=\&e=12312\&ger=354\&set=1\&org=rtf4\&idpr od=1005>. Acesso em: 24 mar. 2011.

(2011). Móveis, equipamentos, instrumental cirúrgico veterinário. Disponível em:<http://www.brasmed.com.br/busca.asp?clie=6\&cat=2\&c=\&hr=\&rtd=78hje\&j=\&idped=134 $\& p=1102757 \&$ idpart $=\& h j=34545354353 \& \mid f=$ doo234\&l=\&e=12312\&ger=354\&set=1\&org=rtf4> . Acesso em: 12 mar. 2011.

BRIANZA, S.Z.M.; DELISE, M.; FERRARIS, M.M. (2006). Cross-section geometrical properties of distal radius and ulna in large, medium and toy breeds dogs. Journal of Biomechanics, New York, v. 39, n. 2, p. 302-311.

BRIEN, W.W.; BRUCE, W.J.; SALVATTI, E.A. (1990). Acetabular reconstruction with a bipolar protheses and morselized bone grafts. Journal of Bone and Joint Surgery, Boston, v. 72 , n. 8, p. 1230-1235, Sept. 
BRINKER, W.O.; PIERMATTEI, D.L.; FLO, G.L. (1999). Manual de ortopedia e tratamento das fraturas dos pequenos animais. 3.ed. São Paulo: Manole.

BURNY, F.; DONKERWOLDKE, M.; MUSTER, D. (1995). Biomaterials education: a challenge for medicine and industry in the late 1990s. Materials Science and Engineering A, Amsterdam, v. 199, n.1, p. 53-59, Aug.

CABRAL, F.J.S.P. et al. (2006). Revisão de artroplastia total de quadril utilizando haste femoral de Wagner. Revista Brasileira de Ortopedia, São Paulo, v. 41, n. 10, p. 393-398.

CALLISTER JR., W.D. (2002). Materials science and engineering: an introduction. $5^{\text {th }}$ ed. New York: John Willey.

CAMARGO, T.C. (2007). Eficácia da esterilização a vapor de instrumental laparoscópico montado versus desmontado. $123 \mathrm{f}$. Dissertação (Mestrado) - Escola de Enfermagem, Universidade de São Paulo, São Paulo, 2007.

CAMILO, C.C. (2006). Escafoldes para implantes ósseos em alumina/hidroxiapatita/biovidro: analises mecânica e in vitro. $42 \mathrm{f}$. Dissertação (Mestrado) - Escola de Engenharia de São Carlos, Universidade de São Paulo, São Carlos, 2006.

CAMPBELL, A.A. (2003). Bioceramics for implants coatings. Materials Today, Amsterdam, v. 6 , n. 11 , p. $26-30$, Nov.

CARVALHO, P.I.; CARVALHO, F.A.; AVELAR, A.D. (1993). Avaliação radiológica da fixação biológica dos componentes femorais não cimentadas nas próteses totais de quadril segundo Charles Engh. Revista Brasileira de Ortopedia, Belo Horizonte, v. 28, n. 6, p. 375-381, jun.

CARVALHO, P.I. et al. (1996). O Uso da osteotomia de Wagner modificada nas cirurgias de revisão. Revista Brasileira de Ortopedia, Belo Horizonte, v. 31, n. 10, p. 821-824.

CATALANI, L.H. (2011). Introdução à ciência dos biomateriais. Notas de aula. Disponível em:<http://www2.iq.usp.br/docente/lhc/disciplinas/ccm-02242009/introducao_a_biomateriais_aula_1.pdf.>. Acesso em: 10 jan. 2011.

CAVALCANTI, E.H.S. et al. (2002). Avaliação da resistência à corrosão de prótese total de quadril de aço inoxidável austenitico removida de paciente. In: CONFERÊNCIA SOBRE TECNOLOGIA DE EQUIPAMENTOS, 6./ CONGRESSO BRASILEIRO DE CORROSÃO, 22., 2002, Salvador. Anais... Disponível em:<http://www.aaende.org.ar/sitio/biblioteca/material/PDF/cote230.PDF>. Acesso em: 14 fev. 2002.

CHAPCHAL, G.; MÜLLER, W. (1970). Total hip replacement with the McKee prosthesis. Clinical Orthopaedics and Related Research, Philadelphia, v. 72, p. 115-122, Sept./Oct.

CHAPIRO, A. (1995). Radiation chemistry in the field of biomaterials. Radiation Physics and Chemistry, Amsterdam, v. 46, n. 2, p. 159-160, Aug.

CHOHFI, M.; KÖBERLE, G.; REIS, F.B. (1997). Prótese metal/metal: uma tendência? Revisão. Revista Brasileira de Ortopedia, Belo Horizonte, v. 32, n. 10, p. 760-766, out. 
COOK, J.L.; SCHOLAR, W.C.A.E. (2007). Guest editorial. Future trends in joint replacement and tissue engineering in small animal orthopedics. Veterinary Surgery, Malden, v. 36, n. 4, p. 287-288, June.

COOK, J.L.; TOMLINSON, J.L.; CONSTANTINESCU, G.M. (1996). Pathophysiology, diagnosis, and treatment of canine hip dysplasia. Compendium on Continuing Education for the Practicing Veterinarian, Princeton Junction, v. 18, n. 8, p. 853-867, Aug.

COOPER DOWSON, D.; FISHER, J. (1993). Macroscopic and microscopic wear mechanism in ultra-high molecular weight polyethylene. Wear, Amsterdam, v. 162-164, part A, p. 378-384, Apr.

COOPER, J.R. et al. (1991). Ceramic bearing surfaces in total artificial joints: resistance to third body wear damage from bone cement particles. Journal of Medical Engineering \& Technology, London, v. 15, n. 2, p. 63-67.

CORNELL, C.N.; LANE, J.M. (1998). Current understanding of osteoconduction in bone regeneration. Clinical Orthopaedics and Related Research, Philadelphia, n.355 (Suppl.), p. S267-S273.

COSTA, C.A. (1997). Biocompatibilidade do polímero de poliuretana vegetal derivada do óleo de mamona em estudo comparativo com cimento de óxido de zinco e eugenol.

Avaliação histopatológica de implantes subcutâneos de ratos. Odonto 2000, Araraquara, v. 1, n. 1, p. 44-48.

CUTTS, S.; CARTER, P.B. (2006). Hip resurfacing: a technology reborn. Postgraduate Medical Journal, London, v. 82, n. 974, p. 802-805, Dec.

DÂNGELO, J.G.; FATTINI, C.A. (1998). Anatomia humana sistêmica e segmentar para o estudante de medicina. 2.ed. São Paulo: Atheneu.

DAVID, T. (1985). Atlas de cirurgia de pequenos animais: técnicas cirúrgicas para clínicos. In: ATLAS der kleintierchirurgie operations: techniken fur die práxis. São Paulo: Manole. p. 472-483.

DE YOUNG, D.J. et al. (1992). Implantation of uncemented total hip prosthesis: technique and initial results of 100 arthroplasties. Veterinary Surgery, Malden, v. 21, n. 3, p. 168-177, May.

DISEGI, J.A.; ESCHBACH, L. (2000). Sainless steel in bone surgery. Injury: International Journal of the Care of the Injured, New York, v. 31, Suppl. 4, p. 2-6, Dec.

DONACHIE, M. (1998). Biomedical alloys. Advanced Materials \& Process, Metals Park, v. 154 , n. 1, p. 63-65, July.

DOWELL, P. (2010a). German sherped dog pélvis as sun from below. Disponível em:<http://pal.pearson.com/?action=12\&basket_uois=cf2b3822c6438a066530c21ec79c4c21 cb979dc67\&position>. Acesso em: 24 Nov. $201 \overline{0}$.

. (2010b). Left femur-adult-front view: a great donis thigh bone. Disponível em:<http://pal.pearson.com/?action=12\&basket-uois=dc045b4c965f6aif65dda263e441193d 6c3c51ab\&position>. Acesso em: 24 Nov. 2010.

DPO (2011). Prótese de quadril. Disponível em:<http://www.dpoltda.com.br/>. Acesso em: 21 jan. 2011. 
DRUMOND, S.N.; PAIVA, E.B.; LIMA, M.B.O. (1999). Revisão de solturas assépticas acetabulares em artroplastias totais de quadril. Revista Brasileira de Ortopedia, São Paulo, v. 34, n. 3, p. 185-192, mar.

DUCHEYNE, P.; GARTH, W.H.; CHEN, C. (1982). Functional behavior of orthopedic biomaterials. Boca Raton: CRC Press. v. 2.

EATON, E.; CAPELLO, W.N. (1983). Reconstruction of acetabular deficiency utilizing iliac bone graft. Orthopaedics, v. 6, n. 973.

ELIAS, N.; PEQUENO, M.O.; CASTRO, M.G. (1990). Afrouxamento asséptico em artroplastia total do quadril. Revista Brasileira de Ortopedia, Belo Horizonte, v. 25, n. 5, p. 137-142.

ETCHEBEHERE, E.C.S.C. (1998). Recentes avanços em densitometria óssea. Jornal do Médico, São Paulo, p. 7.

FERRADOSA, A.S. et al. (2004). Avaliação clínica e radiográfica da incorporação do enxerto homólogo estrutural em revisão de artroplastia total de quadril. Revista Into, Rio de Janeiro, v. 2, n. 3, p. 35-42, set./dez.

FERREIRA, M.I.C. (2010). Anatomia canina. Disponível em:<http://www.canilvonborghen.com/anatomia.htm>. Acesso em: 24 nov. 2010.

FORTULAN, C.A. (1997). Desempenho das cerâmicas estruturais associados aos métodos de conformação por injeção isostática e projetos de equipamentos e moldes. 189 f. Tese (Doutorado) - Escola de Engenharia de São Carlos, Universidade de São Paulo, São Carlos, 1997.

FOSSUM, T.W. (2002). Cirurgia de pequenos animais. São Paulo: Roca.

FRAKER, A.C.; RUFF, A.W. (1977). Metallic surgical implants: state of art. Journal of Metals, New York, v. 29, p. 22-28, May.

FREEMAN, M.A.R. (1978). Some anatomical and mechanical considerations relevant to the surface replacement of the femoral head. Clinical Orthopaedics and Related Research, Philadelphia, n. 134, p. 19-24, July/Aug.

FREEMAN, P.A. (1970). McKee-Farrar total replacement of the hip in rheumatoid arthritis and allied conditions. Clinical Orthopaedics and Related Research, Philadelphia, n. 72, p. 106-114, Sept./Cot.

FREITAS, E. et al. (1997). Artroplastia total de quadril com prótese cimentada de Charnley. Revista Brasileira de Ortopedia, Belo Horizonte, v. 32, n.10, out.

GAMBERDELLA, P.C. (1981). Legg-calve-perthes in dogs. In: BOJRAB, M.J.

Pathophysiology in small animal surgery. Philadelphia: Lea \& Febiger. p. 625-630.

GOMIDE, V.S. (2005). Desenvolvimento e caracterização mecânica de compósitos hidroxiapatita-zircônia, hidroxiaptita-alumina e hidroxiapatita-titânia para fins biomédicos. 121 f. Dissertação (Mestrado) - Faculdade de Engenharia Mecânica, Universidade Estadual de Campinas, Campinas, 2005. 
GRIGORIS, P. et al. (2005). The Evolution of hip resurfacing arthroplasty. Orthopaedic Clinics of North America, Amsterdam, v. 36, n. 2, p. 125-134, Apr.

HALL, R.M. et al. (1997). The Effect of surface topography of retrieved femoral heads on the wear of UHMWPE sockets. Medical Engineering \& Physics, Amsterdam, v. 19, n. 8, p. 711-719, Oct.

HARTUNG, K.; HASSELT, S.C. (1988). Morphometrische untersuchungen am femurknochen des hundes. Berliner und Münchener Tierärztliche Wochenschrift, Berlin, v. 101, p. 15-79.

HAUPTMAN, J.; CARDINET, G.H.; MORGAN, J.P. (1985). Angles of inclination and anteversion in hip dysplasia in the dog. American Journal of Veterinary Research, Chicago, v. 46, n. 10, p. 2033-2036, Oct.

HAUPTMAN, J. et al. (1979). The Angle of inclination of the canine femoral head and neck. Veterinary Surgery, Malden, v. 8, n. 3, p. 74-77, July.

HAYASHI, K. (2009). Total hip replacement in dogs. Disponível em:<http://www.acvs.org/AnimalOwners/HealthConditions/SmallAnimalTopics/TotalHipRepla cement(THR)inDogs/>. Acesso em: 20 Nov. 2010.

HENCH, L.L. (1993). Bioceramics: from concept to clinic. American Ceramic Society, Easton, v. 74, n. 7, p. 1487-1510.

HENCH, L.L. et al. (1972). An Investigation of bonding mechanisms at the interface of ceramic prosthetic materials. Journal of Biomedical Materials Research Symposyum, New York, v. 5, n. 6, p. 117-141, Sept.

HIP resurfacing surgery. (2011a). Disponível em:<http://www.activejoints.com/resurfacing.html\#word>. Acesso em: 10 Jan. 2011.

HIPPERT, E.; AZEVEDO, C.R.F. (2002). Alguns casos de análise de falhas de implantes cirúrgicos. São Paulo: Instituto de Pesquisas Tecnológicas.

HISTORY OF THE USE OF BONE CEMENT IN TOTAL HIP SURGERY (2011). Disponível em:<http://www.totaljoints.info/BONECEMENT_HISTORY.htm>. Acesso em: 19 Jan. 2011.

HOHN, R.B.; JANES, J.M. (1993). Approach to the ilium through a lateral incision. In: PIERMATTEI, D.L. Atlas of surgical approaches to the bones and joints of the dog and cat. $3^{\text {th }}$ ed. Philadelphia: W.B.Saunders.

IDO, K. et al. (1993). Cementless total hip replacement. Acta Orthopaedica Scandinavica, Abingdon, v. 64, n. 6, p. 607-612.

IWATA, D. et al. (2008). Total hip arthroplasty outcomes assessment using functional and radiographic scores to compare canine systems. Veterinary and Comparative Orthopaedics and Traumatology, Salt Lake, v. 21, n. 3, p. 221-230.

JOHNSON, A.L; HULSE, D.A. (2002). Diseases of the joints. In: FOSSUM, T.W. (Ed.). Small animall surgery. $2^{\text {nd }}$ ed. St.Louis: Mosby. p. 1023-1157.

KAPATKIN, A.S.; FORDYCE, H.H.; MAYHEW, P.D. (2002). Canine hip dysplasia:the disease and its diagnosis. Compedium on Continuing Education for the Practicing Veterinarian, Princeton junction, v. 24, n .7, p. 526-537, July. 
KATTI, K. (2004). Biomaterials in total join replacement. Colloids and Surfaces B: biointerfaces, Amsterdam, v. 39, n. 3, p.133-142, Dec.

KAWACHI, E.Y. et al. (2000). Biocerâmica: tendências e perspectivas de uma área interdisciplinar. Química nova, São Paulo, v. 4, n. 23, p. 518-522.

KEALY, J.K.; McALLISTER, H. (2000). Diagnostic radiology and ultrasonograph of the dog and cat. $3^{\text {th }}$ ed. Philadelphia: W.B. Saunders.

KLEIN, A.; FREDEL, M.C.; WENDHAUSEN, P.A.P. (2001). Novos materiais: realidade e tendências de desenvolvimento. Revista Nexus, maio. Disponível em:<www.revistanexus.com.br>. Acesso em: 30 out. 2008.

KURTZ, S.M. et al. (1999). Advances in the processing sterilization and crosslinking of ultra hight molecular weight polyethylene for total joint arthroplasty. Biomaterials, Amsterdam, v. 20 , n. 18, p. 1659-1688, Sept.

KUSHIYAMA, W.; ISHIDA, A.; TRIGUEIRO, G. (2001). Avaliação clínica e radiográfica do componente acetabular nas artroplastias totais de quadril com a prótese não cimentada de Spotorno. Revista Brasileira de Ortopedia, Belo Horizonte, v. 36, n. 10, p. 381-388, out.

LAGE, J.A.; FAGA, A. (2003). Prótese de recapeamento (resurfacing) do quadril - uma esperança para o paciente jovem e ativo - nossa impressão com os primeiros 50 casos. Disponível em:<http:www.clinicalage.com.br/atigos/art_recap.html>. Acesso em: 28 mar. 2009.

LATHAM, B.; GOSWAMI, T. (2004). Effect of geometric parameters in the design of hip implants paper IV. Materials and Design, Amsterdam, v. 25, n. 8, p. 715-722, Dec.

LEGEROS, R.Z. (1991). Calcium phosphates in oral biology and medicine. In: MYERS, H.M. Monografs in oral science. São Francisco: [s.n]. p. 45.

LEIVAS, T.P.; SOUZA, G.F.M.; GONÇALVES, E. (1992). Próteses ortopédicas substituirão ossos humanos. Revista Politécnica, São Paulo, v. 89, n. 207, p. 35.

LIMA, R.S.; XAVIER, C.A.M.; VOLPON, J.B. (1994). Uma Variação do acesso cirúrgico lateral do quadril. Estudo em cadáver. Revista Brasileira de Ortopedia, Belo Horizonte, v. 29 , n. 6 , p. 358-362, jun.

LIPPINCOTT, C.L. (1981). Improvement of excision arthroplasty of the femoral head and neck utilizing a biceps temoris muscle sling. Journal of the American Animal Hospital Association, Elkart, v. 17, n. 4, p. 668-672.

LISKA, W.D.; POTEET, B.A. (2003). Pulmonary embolism associated with canine total hip replacement. Veterinary Surgery, Malden, v. 32, n. 2, p. 178-186, Mar.

LOUGHEAD, J.M. (2005). Comparison of offset in birmingham hip resurfacing and hybrid total hip arthroplasty. Journal of Bone and Joint Surgery, London, v. 87, n. 2, p.163-166, Mar.

LOVERIDGE, N. (1999). Bone: more than a stick. Journal of Animal Science, Albany, v. 77, p.190-96, Jan. 
MATOS, D.R. (2006). Qualidade de vida e reabilitação: casos cirúrgicos de artroplastia total de quadril. $186 \mathrm{f}$. Dissertação (Mestrado) - Instituto de Psicologia, Universidade de Brasília, Brasília, 2006.

McKEE, G.K.; WATSON-FARRAR, J. (1966). Replacement of arthritic hips by the McKeeFarrar prosthesis. Journal of Bone and Joint Surgery, London, v. 48, n. 2, p. 245-259, May.

McMINN, D.J.W. et al. (1996). Metal on metal surface replacement of the hip, experience of the McMinn prosthesis. Clinical Orthopaedics and Related Research, Lippincott, v. 329, p. 89-98, Aug.

MELLO, G.M.R. et al. (2003). Desenvolvimento de ligas do tipo $\beta$ para aplicações em próteses totais de quadril. Jornadas SAM/CONAMET. Disponível em:<http:www.materiales-sam.org.ar/>. Acesso em: 12 nov. 2010.

METALS Handbook. (1980). $9^{\text {th }}$ ed. Metals Park Ohio: American Society for Metals. v. 11, p. 670-694.

MINTO, B.W. et al. (2006). Prótese total da articulação coxofemoral em cães. Vetrinária e Zootecnica, Botucatu, v. 13, n. 1, p. 7-17.

. (2008). Artroplastia total coxofemoral em cães: estudo experimental com prótese nacional. Ciência Rural, Santa Maria, v. 38, n. 1, p.136-142, jan./fev.

MONTAGNOLI, C. (2010). Qualidade, tecnologia e segurança. Disponivel em:<http:// mbosteos1.tempsite.ws/site/internaArtigos.aspx?id_artigo=2>. Acesso em: 14 dez. 2010.

MONTGOMERY, R.D. et al. (1992). Total hip arthroplasty for treatment of canine hip dysplasia. Veterinary Clinics of North America: small animal practice, Philadelphia, v. 22, n. 3, p. 703-719, May.

MOREIRA JUNIOR, E.M.M. (2011). Displasia. Disponível em:<http://superfritz.wordpress.com/>. Acesso em: 15 mar. 2011.

OHARA, G.H. et al. (1995). Estudo experimental da biocompatibilidade do polímero de mamona implantada intra-óssea e intra-articular em coelhos. Acta Ortopédica Brasileira, São Paulo, v. 3, n. 2, p. 62-68.

OLMSTEAD, M.L. (1987). Total hip replacement. Veterinary Clinics of North America: small animal practice, Philadelphia, v. 17, n. 4, p. 943-54, July.

OLMSTEAD, M.L.; SIDEBOTHAM, C. (1991). Premiliary report on a new canine modular total hip. Veterinary Surgery, Malden, v. 20, n. 5, p. 329-352.

OLMSTEAD, M.L. et al. (1981). Technique for canine total hip replacement. Veterinary Surgery, Malden, v. 10, n. 1, p. 44-50, Jan.

. (1983). A Five-year study of 221 total hip replacement in the dog. Journal of the American Veterinary Medical Association, Chicago, v. 183, n. 2, p. 191-194.

OONISHI, H.; TSUJI, E.; KIM, Y.Y. (1998). Part I the effects of cup tickness, head sizes and fusion defects on wear. Journal of Materials Science: materials in medicine, London, v. 9, n. 7 , p. 393-401, July. 
OPERATIVE technique for the cormet ${ }^{\circledR}$ metal - on - metal, hip resurfacing system. (2001). Florida.

ORTOP: instrumentos cirúrgicos. (2011). Disponível

em:<http://www.ortop.com.br/arquivos/produtos/serra\%20ossea\%20autoclavavel\%20pneum atica.gif>. Acesso em: 12 mar. 2011.

OTSUKA, N.Y. et al. (1994). Fixation with biodegradable devices of acetabular components in a canine model. Clinical Orthopaedic, Philadelphia, v.306, p.250-255, Sept.

PAGE, A.E.; ALLAN, C.; JASTY, M. (1993). Determination of loading parameters in the canine hip in vivo. Journal of Biomechanics, New York, v. 26, n. 4/5, p. 571-579, Apr./May.

PALASTANGA, N.; FIELD, D.; SOAMES, R.W. (2000). Anatomia e movimento humano: estrutura e função. São Paulo: Manole.

PALIERNE, S.; ASIMUS, E.; MATHON, D. (2006). Geometric analysis of the proximal femur in a diverse sample of dogs. Research in Veterinary Science, Oxford, v. 80, n. 3, p. 243252, June.

PARK, J.B.; LAKES, R. S. (1992). Biomaterials - an introduction. $2^{\text {nd }}$ ed. New York: Plenum Press.

PERNELL, R. T.; GROSS, R.S.; MILTON, J.L. (1994). Femoral strain distribution and subsidence after physiological loading of a cementless canine femoral prosthesis: the effects of implant orientation, canal fill, and implant fit. Veterinary Surgery, Malden, v. 23, n. 6, p. 503-518, Nov.

PESSAN, V.J.O.; VOLPON, J.B.; SHIMANO, A.C. (1996). Ensaio mecânico de flexão nas faces côncava e convexa da diáfise do fêmur de ratas. Revista Brasileira de Ortopedia, São Paulo, v. 31, n. 7, p. 600-604, jul.

PETERSEN, S. (2003). Hip replacement: design and developmet. Tese (Doutorado). Disponível em:<www.geocities/hip_replacements>. Acesso em : 25 maio 2010.

PICONI, C.; MACCAURO, G. (1999). Zirconia as a ceramic biomaterial. Biomaterials, Amsterdam, v. 20, n. 1, p. 1-25, Jan.

PIERMATTEI, D.L.; FLO, W.B. (1979) Handbook of small animal orthopaedcs and fracture repair. Philadephia: Saunders. p. 462-511.

PIERMATTEI, D.L.; GREELEY, R.G. (1979). An Atlas of surgical approaches to the bones of the dog and cat. $2^{\text {nd }}$ ed. Philadelphia: W.B. Saunders. p.132-133.

PIERMATTEI, D; FLO, G.; DeCAMP, C.E. (2006). The Hip joint. In: BRINKER, W.O. Handbook of small animal orthopedics and fracture repair. $4^{\text {th }}$ ed. Philadelphia: W.B. Saunders.

PIETRABISSA, R.; RAIMONDI, D.; MARTINO, E. (1998). Wear of polyethylene cups in total hip arthroplasty: a parametric mathematical model. Medical Engineering \& Physics, Amsterdam, v. 20, n. 3, p.199-210, Apr.

POOYA, H.A. et al. (2003). Short-term evaluation of dorsal acetabular augmentation im 10 canine total hip replacement. Veterinary Surgery, Malden, v. 32, n. 2, p.142-152, Mar. 
PRESTON, C.A. et al. (1999). Total hip artroplasty in nine canine hind limb amputees: a retrospective study. Veterinary Surgery, Malden, v. 28, n. 5, p. 341-347, Sept.

PRITCHETT, J.W.; TOWNLEY, C.O. (2002). Hip joint resurfacing - minimum 20 - year follow-up. Disponível

em:<http://www.carnationclinic.com/index.cfm?fuseaction=ct.content\&apid=314>. Acesso em: 19 Nov. 2010.

QUEIROZ, R.D. et al. (2001). Análise do desgaste do polietileno do componente acetabular da prótese total de quadril, utilizando o método de elementos finitos de simulação

computadorizada. Revista Brasileira de Ortopedia, Belo Horizonte, v. 36, n. 5, p. 149-154, maio.

RABELO, J. (2006). Biomateriais. Disponível

em:<http://biomateriais.blogspot.com/2006/03/implantes-cermicos.html>. Acesso em: 18

Feb. 2011.

REMEDIOS, A.M.; FRIES, C.L. (1995). Treatment of canine hip dysplasia: a review.

Canadian Veterinary Journal, Guelph, v. 36, n. 8, p. 503-509, Aug.

RICHARDSON, D.C. (1992). The Role of nutrition in canine hip dysplasia. Veterinary

Clinics of North America: small animal practice, Philadelphia, v. 22, n. 3, p. 529-540, May.

RIGO, E.C.S. et al. (1999). Implantes recobertos com hidroxiapatita. Revista Brasileira de

Engenharia Biomédica, Rio de Janeiro, v. 15, n. 1/2, p. 21-29, jan./ago.

ROBERTS, P. et al. (2005). Resurfacing arthroplasty of the hip. Current Orthopaedics, Amsterdam, v. 19, n. 4, p. 263-279, Aug.

RODRIGUES, E. (2004). Implantes de aço inoxidável cada vez mais resistentes à corrosão. Disponível

em:<http://www.eesc.usp..br/bioeng/mostra_noticia.php?id=68\&de=noticias.php>. Acesso em: 15 dez. 2010.

RONDINELLI, P.C. et al. (1993). Cirurgia de revisão na artroplastia do quadril com utilização de enxertos de banco de osso. Revista Brasileira de Ortopedia, Belo Horizonte, v. 28, n. 6, p. 343-352, jun.

RUDELLI, S.; HONDA, E.; ANGELL, J.A. (1992). O Uso de enxerto ósseo nas revisões com prótese total do quadril não cimentada e híbrida. Revista Brasileira de Ortopedia, Belo Horizonte, v. 27, p. 281-288.

SAIKKO, V. (1993). Wear and friction properties of prosthetic joint materials evaluated on a reciprocating pin-on-flat appatarus. Wear, Amsterdam, v.166, n. 2, p. 169-178, July.

SANTOS, M. (2010). Displasia coxo-femoral. Disponível em:<http://saobernardobig.com.sapo.pt/veterinaria.htm>. Acesso em: 20 fev. 2010.

SAWAKI, A.T.; KAWASAKI, J.M.; ZILIOTO, A.R.B. (1992). Desenvolvimento de alumina para próteses de fêmur. In: CONGRESSO BRASILEIRO DE CERAMICA, 36., 1992, Caxambu, Anais... São Paulo: Associação Brasileira de Cerâmica. p. 975-982.

SCHAWALDER, V.P.; STERCHI, H.P. (1981). Der centrum-collum-diaphysenwinkel und der antetorsionswinkel beim hund. Kleintier Praxis, Alfeld, v. 26, n. 3, p. 151-162. 
SCHULZ, K. (2008). Afecções articulares. In: FOSSUM, T.W. Cirurgia de pequenos animais. Rio de Janeiro: Mosby. p. 1143-1315.

SCHULZ, K.S. (2000). Application of arthroplasty Principles to canine cemented total hip replacement. Veterinary Surgery, Malden, v. 29, n. 6, p. 578-593, Nov.

SCHULZ, K.S. et al. (1998). Transverse plane evaluation of the effects of surgical technique on stem positioning and geometry of reconstruction in canine total hip replacement.

American Journal of Veterinary Research, Chicago, v. 59, n. 8, p. 1071-1079.

SEELEY, STEPHENS, TATE - anatomia e fisiologia. (1997). Lisboa: Lusodidacta. Disponível em:<http://www.scribd.com/doc/2364226/fractura-trocanterica>. Acesso em: 25 nov. 2010.

SEMLITSCH, M. (1984). Metallic Implant materials for hip joint endoprostesis designed for cemented and cementless fixation. In: MORSCHER, E. (Ed.). The Cementless fixation of hip endoprosthesis. Berlin: Springer-Verlag. p. 59-70.

SEYLER, T.M. et al. (2006). Limited approach surface replacement total hip arthroplasty. Operative Techniques in Orthopaedics, Amsterdam, v. 16, n. 2, p. 120-125, Abr.

SHIELDS, S.L. et al. (2002). The Effects of acetabular cup temperature and duration of cement pressurization on cement porosity in a canine total hip replacement model.

Veterinary Surgery, Malden, v. 31, n. 2, p. 167-173, Mar.

SHIMMIN, A.J.; BACK, D. (2005). Femoral neck fractures following Birmingham hip resurfacing. Journal of Bone and Joint Surgery, London, v. 87, n. 4, p. 463-464, Apr.

SILVESTRE FILHO, G.D. (2006). Projeto conceitual de haste femoral de implante de articulação de quadril em material compósito polimérico. $157 \mathrm{f}$. Tese (Doutorado) Escola de Engenharia de São Carlos, Universidade de São Paulo, São Carlos, 2006.

SMITH, G.K. (2004). New paradigms for hip dysplasia prevention and control: performance and ethics of CHD screening as an indication for preventive strategies. In: EUROPEAN SOCIETY OF VETERINARY ORTHOPAEDICS AND TRAUMATOLOGY CONGRESS, 12., 2004, Munich. Anais... Disponível em:<http://www.esvot.org/PDF/2004/esvot2004_proceedings.pdf>. Acesso em: 29 July 2009.

SOARES, G.A. (2005). Biomaterias. Rio de Janeiro: UFRJ.

SOMMERFELDT, D.W.; RUBIN, C.T. (2001). Biology of bone and how it orchestrates the form and function of the skeleton. European Spine Journal, Berlin, v. 10, Suppl. 2, p. S85S86, Aug.

STURION, D.J. et al. (2006). Artroplastia excisional pelo acesso dorso-caudal em 16 cães com necrose asséptica na cabeça do fêmur. Arquivos de Ciências Veterinárias e Zoologia da UNIPAR, Umuarama, v. 9, n. 2, p. 111-115.

SULLO \& SULLO LLPATTORNEYS AT LAW (2011). AML® Total hip systems. Disponível em:<http://www.sollolaw.com/resourcecenter.aspx>. Acesso em: 22 Dec. 2010. 
TAKATA, E.T. et al. (1995). Abordagem cirúrgica lateral do quadril com osteotomia parcial do trocânter maior. Revista Brasileira de Ortopedia, Belo Horizonte, v. 30, n. 7, p. 443451, jul.

TAYLOR, M.E. et al. (1996). Stress and strain distribution within the intact femur:compression or bending?. Medical Engineering and Physics, Amsterdam, v. 18, n. 2, p. 122-131, Mar.

TEBECHERANI, C.T.P. (2011). Aços inoxidáveis. Disponível em:<http://www.pipesystem.com.br/Artigos_Tecnicos/artigos tecnicos.html>. Acesso em: 15 nov. 2010.

TILBERG, B. (1988). Total hip arthroplasty using the McKee \& Watson-Farrar prosthesis. Acta Orthopaedica Scandinavica, Kobenhaven, v. 53, n.1, p. 103-107, Fev.

TOMLINSON, J.; McLAUGHLIN JR., R. (1996). Canine hip dysplasia: developmental factors, clinical signs, and initial examination steps. Veterinary Medicine, Ohio, v. 91, n. 1, p. 26-33.

TREACY, R.B.C.; McBRYDE, C.W.; PYSENT, P.B. (2005). Birmingham hip resurfacing arthroplasty. A minimum follow-up of five years. Journal of Bone and Joint Surgery, London, v. 87, n. 2, p. 167-170, Feb.

TRILOGY® Acetabular System. (2008). Disponível em:<http://www.zimmer.nl/producten/heup/acetabular-systems/uncemented/trilogy-cup.>. Acesso em: 15 Jan. 2011.

TRUETA, J. (1975). Estrutura del cuerpo humano: estúdios sobre su desarollo y decadência. Barcelona: Labor.

VALLET-REGI, M.; GONZALÉZ-CELLBET, J. (2004). Calcium phosfates of substitution of bone tissues. New York: Elsevier Science.

VASCONCELOS, Y. (2004). O homem biônico: uma nova safra de implantes artificiais sofisticados reverte doenças que até recentemente não tinham cura. Disponível em:<http://www.portadeacesso.com/artigos_leis/amputados/h_bionico.htm>. Acesso em: 14 fev. 2011.

VILARINHO, R.H.; HETEM, S.; RAMALHO, L.T.O. (1994). Implante de resina de poliuretana vegetal na câmara anterior do olho de camundongo. Odonto 2000, Araraquara, v. 1, n. 1, p. 25-29.

WALCZAK, J.; SHAHGALDI, F.; HEATLEY, F. (1998). Biomaterials, Amsterdam, v. 19, n. 1/3, p. 229-237, Jan.

WALLACE, L.J. (1987). Canine hip dysplasia: past and present. Seminars in Veterinary Medicine and Surgery (Small Animal), Philadelphia, v. 2, n. 2, p. 92-106.

WALLACE, L.J.; OLMSTEAD, M.L. (1995). Disabling conditions of canine coxofemoral joint. In: OLMSTEAD, M.L. Small animal orthopedics. St.Louis: Mosby. p. 361-394.

WANG, A. et al. (1996). Comparison of the size and morphology of UHMWPE wear debris produced by a hip joint simulator under serum and water lubricated conditions.

Biomaterials, v. 17, n. 9, p. 866-871. 
WEBER, B.G. (1996). Experience with the Metasul total hip bearing system. Clinical Orthopaedics, Philadelphia, v. 329, Suppl., p.S69-S77, Aug.

WEIGEL, J.P.; WASSERMAN, J.F. (1992). Biomechanics of the normal and abnormal hip joint. Veterinary Clinics of North America: small animal practice, Philadelphia, v. 22, n. 3, p. 513-528, May.

WENDELBURG, K.L. (1998). Disorders of the hip joint in the canine athlete. In: BLOOMBERG, M.S. Canine sports medicine and surgery. Philadelphia: Saunders. p. 174-195.

WILLIAMS, D.F. (1987). Definitions in biomaterials. In: CONSENSUS CONFERENCE OF THE EUROPEAN SOCIETY FOR BIOMATERIALS, 1987. Chester. Proceedings... New York: Elsevier. (Progress in Biomedical Engineering, 4).

WILLMANN, G. (1996). Production of medical grade alumina. British Ceramic Transactions, v. 95, n. 5, p. 212-216.

WREGE, P.A.S. (2000). Metodologia para obtenção de esferas de cerâmica para próteses de quadril. $187 \mathrm{f}$. Tese (Doutorado) - Escola de Engenharia de São Carlos, Universidade de São Paulo, São Carlos, 2006.

WYSSA, B.; RAUT, V.V.; SINEY, P.D. (1995). Multiple revision for failed charnley lowfriction arthroplasty. Journal of Bone and Joint Surgery, London, v. 77, n .2, p. 303-306, Mar.

ZAVAGLIA, C.A.C. (1993). Aplicações de biocerâmica em próteses ortopédicas. 116 f. Tese (Livre-Docência) - Universidade Estadual de Campinas, Campinas, 1993. 


\section{GLOSSÁRIO}

Artrite - Processo inflamatório tecidual de uma determinada articulação.

Artroplastia - Artroplastia é um procedimento cirúrgico onde ocorre a substituição de uma articulação comprometida que leva a dor persistente, apesar do tratamento medicamentoso e fisioterápico, perda crítica do movimento articular, perda do estado funcional e qualidade de vida ou alterações biomecânicas compensatórias na articulação com osteoartrose e nas articulações adjacentes.

Artroplastia excisional da cabeça do fêmur - Tratamento cirúrgico onde requer a ressecção da cabeça e colo femoral e conseqüentemente aliviando a dor do animal.

Artrose - É um processo degenerativo do tecido cartilaginoso de qualquer articulação do corpo levando conseqüentemente a alterações ósseas, é conhecida também como osteoartrose, osteoartrite, artrite degenerativa e doença articular degenerativa.

Biocompatibilidade - É a capacidade de um material desempenhar uma resposta apropriada em uma determinada aplicação com o mínimo de reações alérgicas, inflamatórias ou tóxicas, quando em contato com tecidos vivos ou fluidos orgânicos, isto é, existe uma interação entre os tecidos e fluidos com o implante ou material.

Calcificação ectópica - Calcificação ectópica ou calcificação patológica é um processo mórbido de origem nas alterações metabólicas celulares. Essas alterações induzem a uma deposição anormal de sais de cálcio e outros sais minerais heterotopicamente, ou seja, em locais onde não é comum a sua deposição. Em outras palavras, a calcificação ectópica é assim definida por se localizar fora do tecido ósseo ou dental, em situações de alteração da homeostase.

Capsulotomia - É a incisão propriamente dita de qualquer cápsula articular.

Claudicação - A claudicação é um sintoma dos membros inferiores causada pela insuficiência de circulação arterial ou trauma que causa uma sensação dolorosa durante exercícios ou caminhar, sintomas resultantes do déficit de suprimento de oxigênio que gera uma dor muscular intensa.

Deambulação - É o ato de caminhar.

Diáfise - É a parte do osso que tem o crescimento primário, ou seja, cresce longitudinalmente, alongando-se. É a parte mais longa, compreendida entre as extremidades, ou epífises. Nos ossos longos a diáfise é composta de grande quantidade de 
osso compacto, com pequena quantidade de osso esponjoso, mais profundamente. Ela também delimita o canal medular.

Displasia - A displasia coxofemoral é uma patologia articular de cães e gatos definida como uma doença hereditária, biomecânica, representada pela disparidade entre a massa muscular primária e o rápido crescimento ósseo, levando a uma instabilidade na articulação coxofemoral.

Em estação - Permanecer em pé.

Epífise - É a parte de um osso longo que se desenvolve por um centro de ossificação diferente do corpo do osso, e que dele é separado por uma camada de cartilagem. A epífise ou cartilagem epifisária é responsável pelo crescimento diametral (lateral) do osso.

Esquírolas ósseas - Pequenas partículas ou fragmentos ósseos.

Etiologia - Estuda as causas gerais de todos os tipos de doenças, podendo ser determinados por fatores intrínsecos ou adquiridos.

Implante - É um dispositivo médico feito para substituir ou atuar como uma estrutura biológica ausente do corpo.

Alógenos - Diz-se daquilo que teve origem em outro ambiente do que se encontra, geralmente são usados para referenciar rochas e minerais.

Autógenos - Que se gera a si mesmo.

Xenógenos - Material desenvolvido fora do organismo.

Metáfise - É uma região do osso compreendida entre a epífise e a diáfise.

Necrose asséptica - É uma condição óssea que resulta de suprimento inadequado de sangue para uma área de osso causando a morte do osso. Esta é uma condição grave, porque as áreas de osso morto não funcionam normalmente, são enfraquecidas, e pode entrar em colapso. Necrose asséptica é também referida como necrose avascular ou osteonecrose

Osteocondução - Se refere à capacidade de alguns materiais servirem de armação sobre a qual células ósseas podem se fixar, migrar (significando se mover ou "se arrastar"), crescer e se dividir. Desse modo, a resposta de cura do osso é "conduzida" através do local do enxerto, assim como dizemos que a eletricidade é conduzida através de um fio. As células osteogênicas geralmente trabalham muito melhor quando possuem uma matriz ou armação onde podem se fixar.

Osteófitos - São Formações ósseas em formas de ganchos que se desenvolvem em torno das articulações de seres humanos e animais.

Osteointegração - É o embricamento mecânico de um determinado implante através do crescimento ósseo ao redor, ou seja, é a adesão do osso ao implante.

Osteólise - É uma destruição do tecido ósseo geralmente associado a um quadro infeccioso. 
Osteoporose - Caracterizam-se quando a quantidade de massa óssea diminui substancialmente e desenvolve ossos ocos, finos e de extrema sensibilidade, mais sujeitos a fraturas.

Osteotomia - É o seccionamento cirúrgico de um osso, com a finalidade de corrigir uma restauração ou deformidade do esqueleto, ou por consolidação viciosa de fratura, ou por anomalias congênitas ou adquiridas.

Patologia - Palavra derivado do grego pathos, sofrimento, doença, e logia, ciência, estudo, é o estudo das doenças em geral.

Pitting - É uma forma de corrosão localizada que consiste na formação de pequenas cavidades e profundidade considerável e o mais importante, significativa frente à espessura do material. Ocorre de maneira extremamente determinada, podendo portanto ser chamada de puntiforme, não apresentando o material circundante ataque.

Tribologia - É derivada das palavras grega TRIBOS que significa atrito, e LOGOS que significa estudo, de forma que uma tradução literal significa 'Estudo do Atrito', ou a ciência que estuda o Atrito. Tribologia é definida como "A ciência e a tecnologia da interação entre superfícies com movimento relativo e dos assuntos e práticas relacionadas".

Prótese - Prótese é um componente artificial que tem por finalidade suprir necessidades e funções dos indivíduos seqüelados seja por amputações, traumática ou não.

Pseudo-artrose - Também denominada de falsa articulação ocorre quando as superfícies fraturadas encontram-se arredondadas e esclerosadas, pois ocorre entre dois ossos fraturados uma falsa articulação onde é um agravante na reabilitação do paciente.

Resurfacing - Palavra de origem Inglesa que significa recapeamento. 
ANEXOS 


\section{ANEXO 1}

- Instrumental cirúrgico para prótese total em cães.

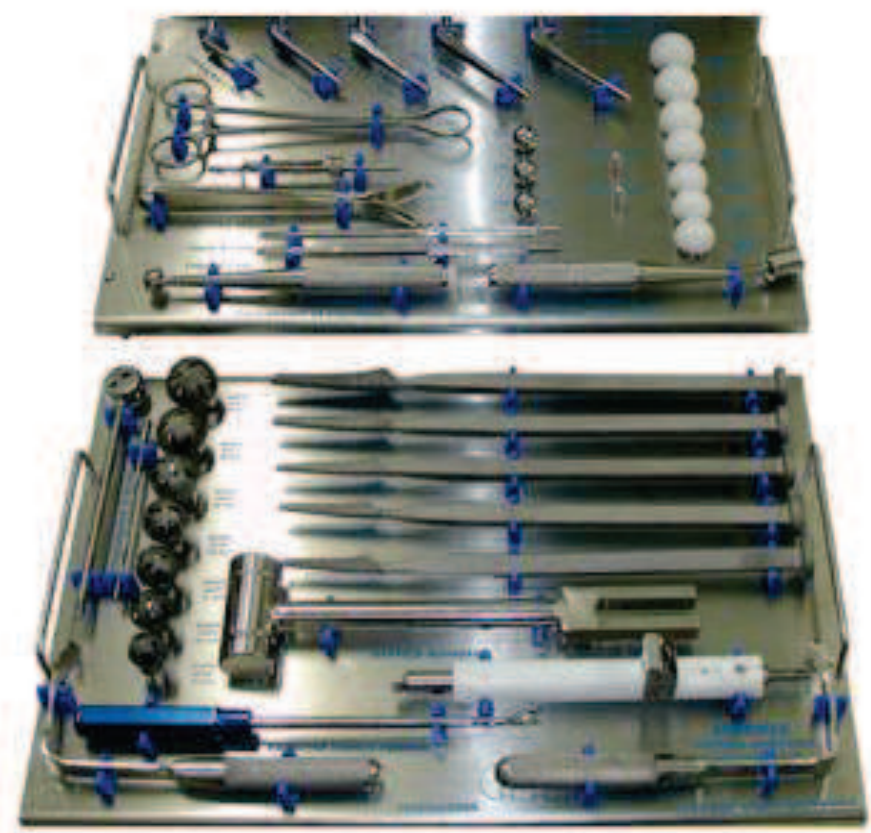

\begin{tabular}{|c|c|}
\hline Quantidade & Descrição \\
\hline 1 & Prótese $n^{0} 4$ \\
\hline 1 & Prótese $n^{\circ} 5$ \\
\hline 1 & Prótese $n^{\circ} 6$ \\
\hline 1 & Prótese $\mathrm{n}^{0} 7$ \\
\hline 1 & Prótese $\mathrm{n}^{\circ} 8$ \\
\hline 1 & Broca $4 \mathrm{~mm}$ com stop \\
\hline 1 & Par de afastador de Homann \\
\hline 1 & Fresa $6 \mathrm{~mm}$ \\
\hline 1 & Fresa $8 \mathrm{~mm}$ \\
\hline
\end{tabular}




\begin{tabular}{|c|c|}
\hline 1 & Posicionador \\
\hline 1 & Impactador \\
\hline 1 & Acetábulo $18 \mathrm{~mm}$ \\
\hline 1 & Acetábulo $20 \mathrm{~mm}$ \\
\hline 1 & Acetábulo $23 \mathrm{~mm}$ \\
\hline 1 & Acetábulo $25 \mathrm{~mm}$ \\
\hline 1 & Acetábulo $27 \mathrm{~mm}$ \\
\hline 1 & Acetábulo $29 \mathrm{~mm}$ \\
\hline 1 & Acetábulo $31 \mathrm{~mm}$ \\
\hline 1 & Cabeça femoral colo curto $16 \mathrm{~mm}$ \\
\hline 1 & Cabeça femoral colo médio $16 \mathrm{~mm}$ \\
\hline 1 & Cabeça femoral colo longo $16 \mathrm{~mm}$ \\
\hline 1 & Cabeça femoral colo curto $12 \mathrm{~mm}$ \\
\hline 1 & Cabeça femoral colo longo $12 \mathrm{~mm}$ \\
\hline 1 & Raspa femoral $n^{\circ} 8$ \\
\hline 1 & Raspa femoral $n^{0} 7$ \\
\hline 1 & Raspa femoral $n^{\circ} 6$ \\
\hline 1 & Raspa femoral $n^{0} 5$ \\
\hline 1 & Raspa femoral $n^{\circ} 4$ \\
\hline 1 & Martelo diapasão \\
\hline 1 & Cabo para fresa acetabular \\
\hline 1 & Par de afastadores \\
\hline 1 & Extrator de cabeça femoral \\
\hline
\end{tabular}




\begin{tabular}{|c|c|}
\hline 1 & Raspa acetabular $19 \mathrm{~mm}$ \\
\hline 1 & Raspa acetabular $22 \mathrm{~mm}$ \\
\hline 1 & Raspa acetabular $24 \mathrm{~mm}$ \\
\hline 1 & Raspa acetabular $26 \mathrm{~mm}$ \\
\hline 1 & Raspa acetabular $28 \mathrm{~mm}$ \\
\hline 1 & Raspa acetabular $30 \mathrm{~mm}$ \\
\hline 1 & Raspa acetabular $32 \mathrm{~mm}$ \\
\hline 1 & Posicionador para raspa acetabular \\
\hline 1 & Posicionador de plug \\
\hline
\end{tabular}

[BRASMED, 2011] 


\section{ANEXO 2}

\section{- Instrumental cirúrgico para prótese de Müller primária}

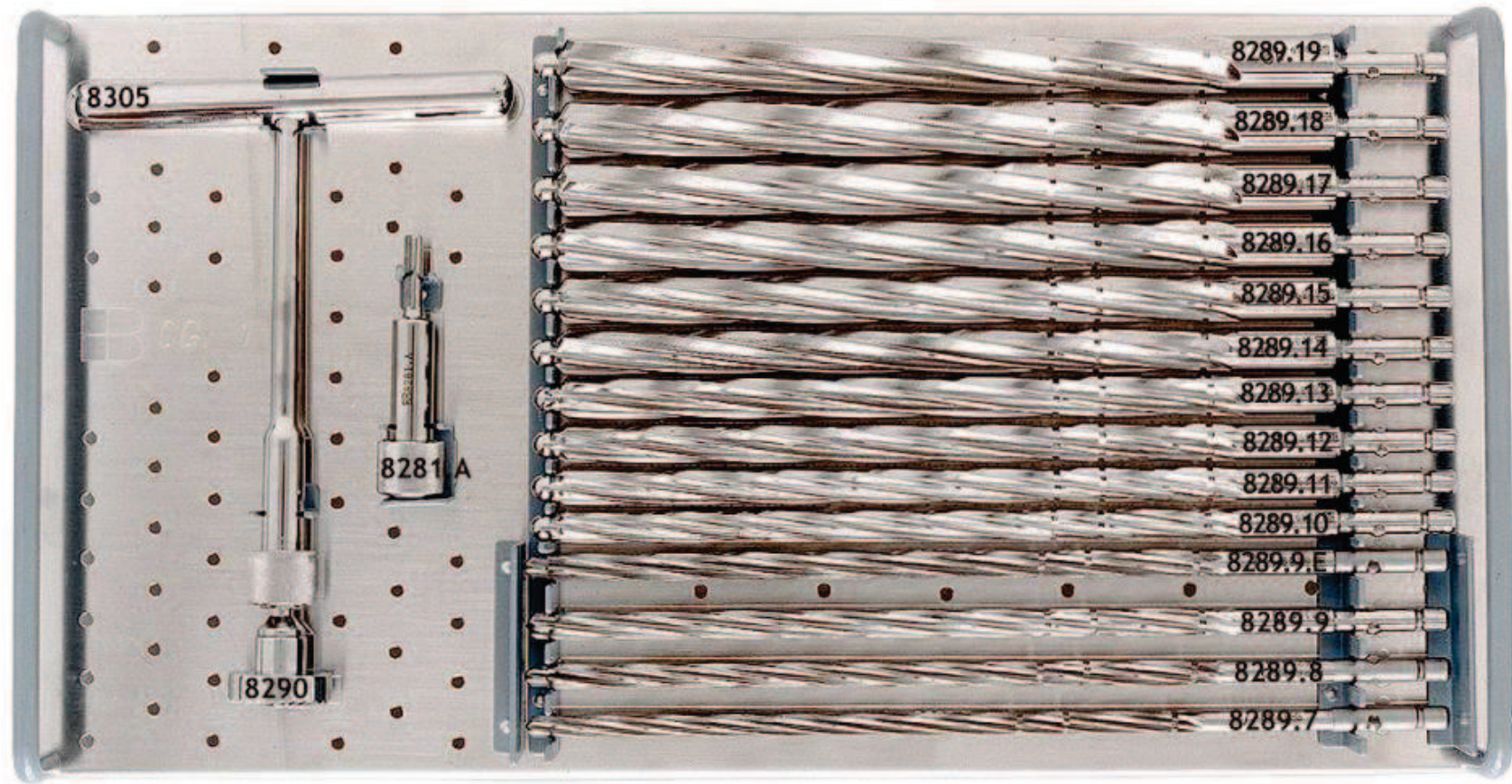

\begin{tabular}{|c|c|c|}
\hline Código & Quantidade & Descrição \\
\hline $8281 . A$ & 1 & Mandril Original Baumer \\
\hline 8289.7 & 1 & Fresa diafisária $-7 \mathrm{~mm}$ \\
\hline 8289.8 & 1 & Fresa diafisária $-8 \mathrm{~mm}$ \\
\hline 8289.9 & 1 & Fresa diafisária com ponta cortante $-9 \mathrm{~mm}$ \\
\hline $8289.9 . \mathrm{E}$ & 1 & Fresa diafisária sem ponta cortante $-9 \mathrm{~mm}$ \\
\hline 8289.10 & 1 & Fresa diafisária 10 $\mathrm{mm}$ \\
\hline 8289.11 & 1 & Fresa diafisária 11 $\mathrm{mm}$ \\
\hline 8289.12 & 1 & Fresa diafisária 12 $\mathrm{mm}$ \\
\hline 8289.13 & 1 & Fresa diafisária 13 $\mathrm{mm}$ \\
\hline 8289.14 & 1 & Fresa diafisária 14 mm \\
\hline
\end{tabular}




\begin{tabular}{|c|c|c|}
\hline 8289.15 & 1 & Fresa diafisária $15 \mathrm{~mm}$ \\
\hline 8289.16 & 1 & Fresa diafisária $16 \mathrm{~mm}$ \\
\hline 8289.17 & 1 & Fresa diafisária $17 \mathrm{~mm}$ \\
\hline 8289.18 & 1 & Fresa diafisária $18 \mathrm{~mm}$ \\
\hline 8289.19 & 1 & Fresa diafisária $19 \mathrm{~mm}$ \\
\hline 8290 & 1 & Fresa de Topo \\
\hline 8305 & 1 & Chave "T" \\
\hline
\end{tabular}

[BAUMER, 2010]

\section{- Instrumental cirúrgico para prótese Alpha Primária}

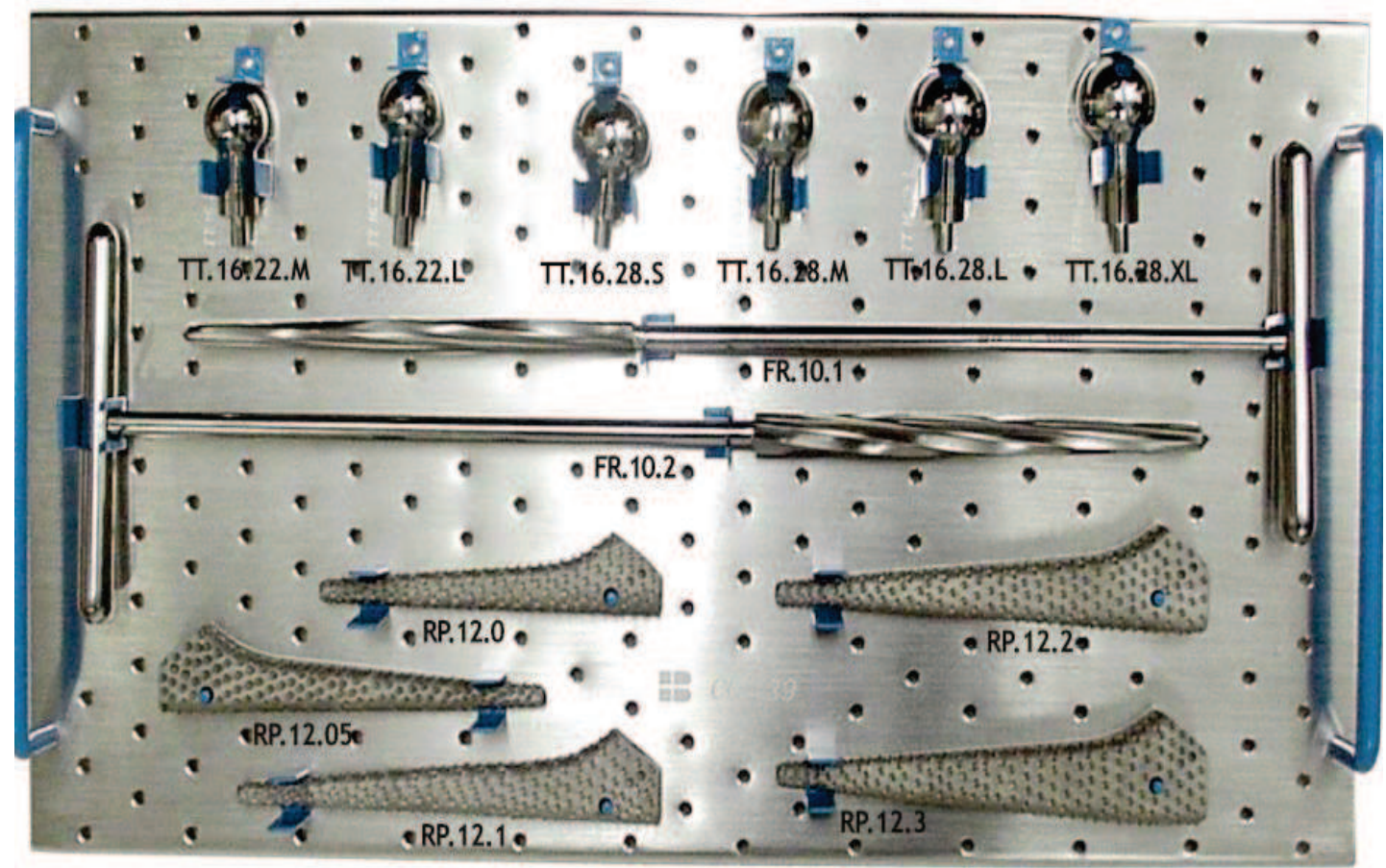

\begin{tabular}{|c|c|c|}
\hline Código & Quantidade & Descrição \\
\hline FR.10.1 & 1 & Fresa diafisária para prótese cimentada \\
\hline
\end{tabular}




\begin{tabular}{|c|c|c|}
\hline FR. 10.2 & 1 & Fresa diafisária para prótese cimentada \\
\hline RP.12.0 & 1 & Raspador da prótese cimentada no. 0 \\
\hline RP.12.05 & 1 & Raspador da prótese cimentada $\mathrm{n}^{\circ} .5$ \\
\hline RP.12.1 & 1 & Raspador da prótese cimentada $\mathrm{n}^{\circ} .1$ \\
\hline RP.12.2 & 1 & Raspador da prótese cimentada $\mathrm{n}^{\circ} .2$ \\
\hline RP.12.3 & 1 & Raspador da prótese cimentada $\mathrm{n}^{\circ} .3$ \\
\hline TT.16.22.M & 1 & Cabeça de teste $-22 \mathrm{~mm}$-médio \\
\hline TT.16.22.L & 1 & Cabeça de teste $-22 \mathrm{~mm}$-longo \\
\hline TT.16.28.S & 1 & Cabeça de teste $-28 \mathrm{~mm}$ - curto \\
\hline TT.16.28.M & 1 & Cabeça de teste $-28 \mathrm{~mm}$-médio \\
\hline TT.16.28.L & 1 & Cabeça de teste $-22 \mathrm{~mm}$-longo \\
\hline TT.16.28.XL & 1 & Cabeça de teste $-28 \mathrm{~mm}-$ Extra longo \\
\hline
\end{tabular}

[BAUMER, 2010] 
- Instrumental cirúrgico para prótese de Thompson Primária e prótese de Charnley Primária /Revisão

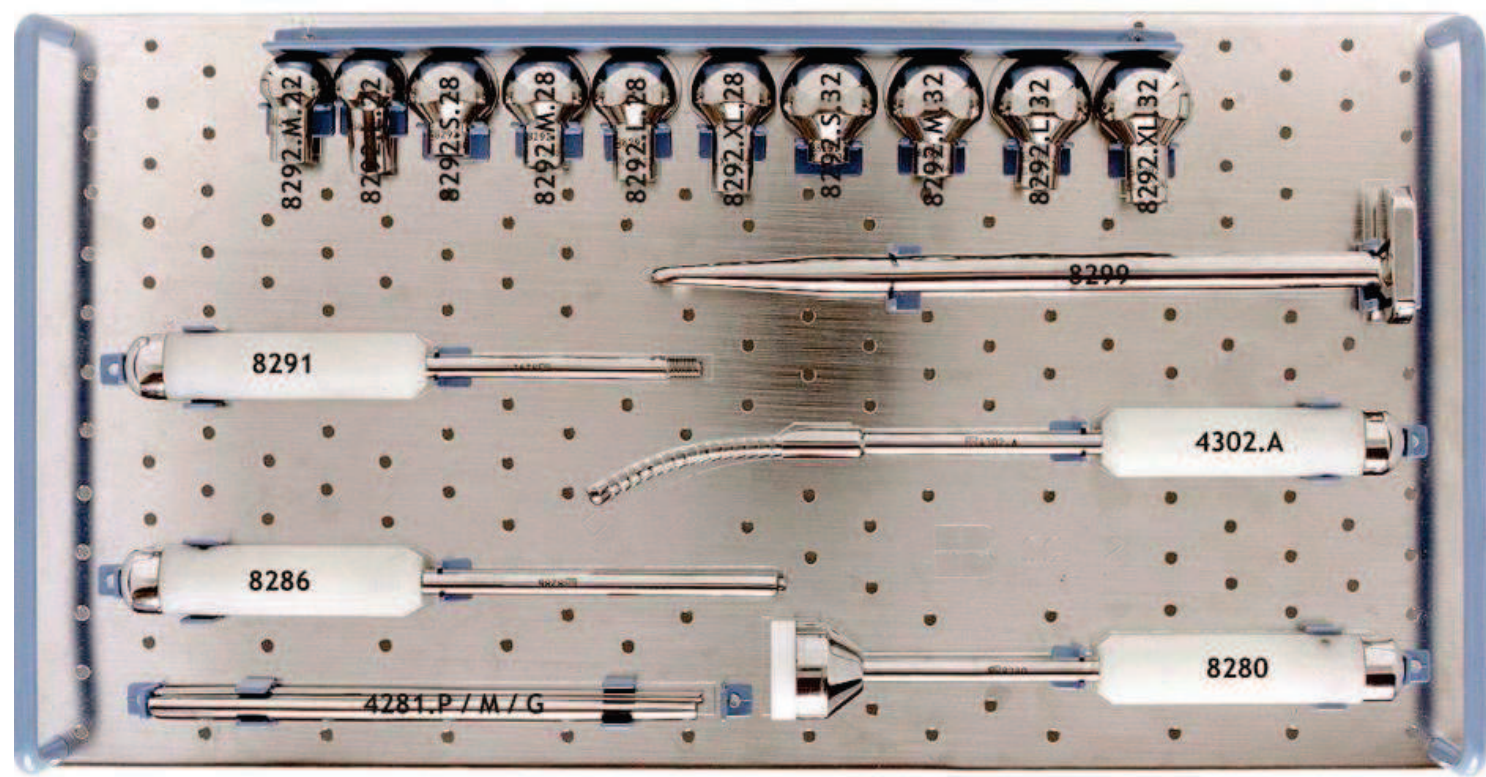

\begin{tabular}{|c|c|c|}
\hline Código & Quantidade & Descrição \\
\hline 4281.G & 1 & Calcador de enxerto grande \\
\hline 4281.M & 1 & Calcador de enxerto médio \\
\hline 4281.P & 1 & Calcador de enxerto pequeno \\
\hline 4302.A & 1 & Raspador curvo \\
\hline 8280 & 1 & Impactor de cabeça \\
\hline 8286 & 1 & Impactor de prótese \\
\hline 8291 & 1 & Cabo padrão \\
\hline 8292.M.22 & 1 & Teste de cabeça femoral médio - $22 \mathrm{~mm}$ \\
\hline 8292.L.22 & 1 & Teste de cabeça femoral longo - $22 \mathrm{~mm}$ \\
\hline 8292.S.28 & 1 & Teste de cabeça femoral curto $-22 \mathrm{~mm}$ \\
\hline 8292.M.28 & 1 & Teste de cabeça femoral médio - $28 \mathrm{~mm}$ \\
\hline 8292.L.28 & 1 & Teste de cabeça femoral longo $-28 \mathrm{~mm}$ \\
\hline
\end{tabular}




\begin{tabular}{|c|c|c|}
\hline 8292.XL.28 & 1 & Teste de cabeça femoral extra longo $-28 \mathrm{~mm}$ \\
\hline 8292.S.32 & 1 & Teste de cabeça femoral curto $-32 \mathrm{~mm}$ \\
\hline 8292.M.32 & 1 & Teste de cabeça femoral médio $-32 \mathrm{~mm}$ \\
\hline 8292.L.32 & 1 & Teste de cabeça femoral longo $-32 \mathrm{~mm}$ \\
\hline 82.92.XL.32 & 1 & Teste de cabeça femoral extra longo $-32 \mathrm{~mm}$ \\
\hline 8299 & 1 & Extrator de Prótese \\
\hline
\end{tabular}

[BAUMER, 2010]

- Instrumental cirúrgico para prótese de Thompson/ Charnley Moore

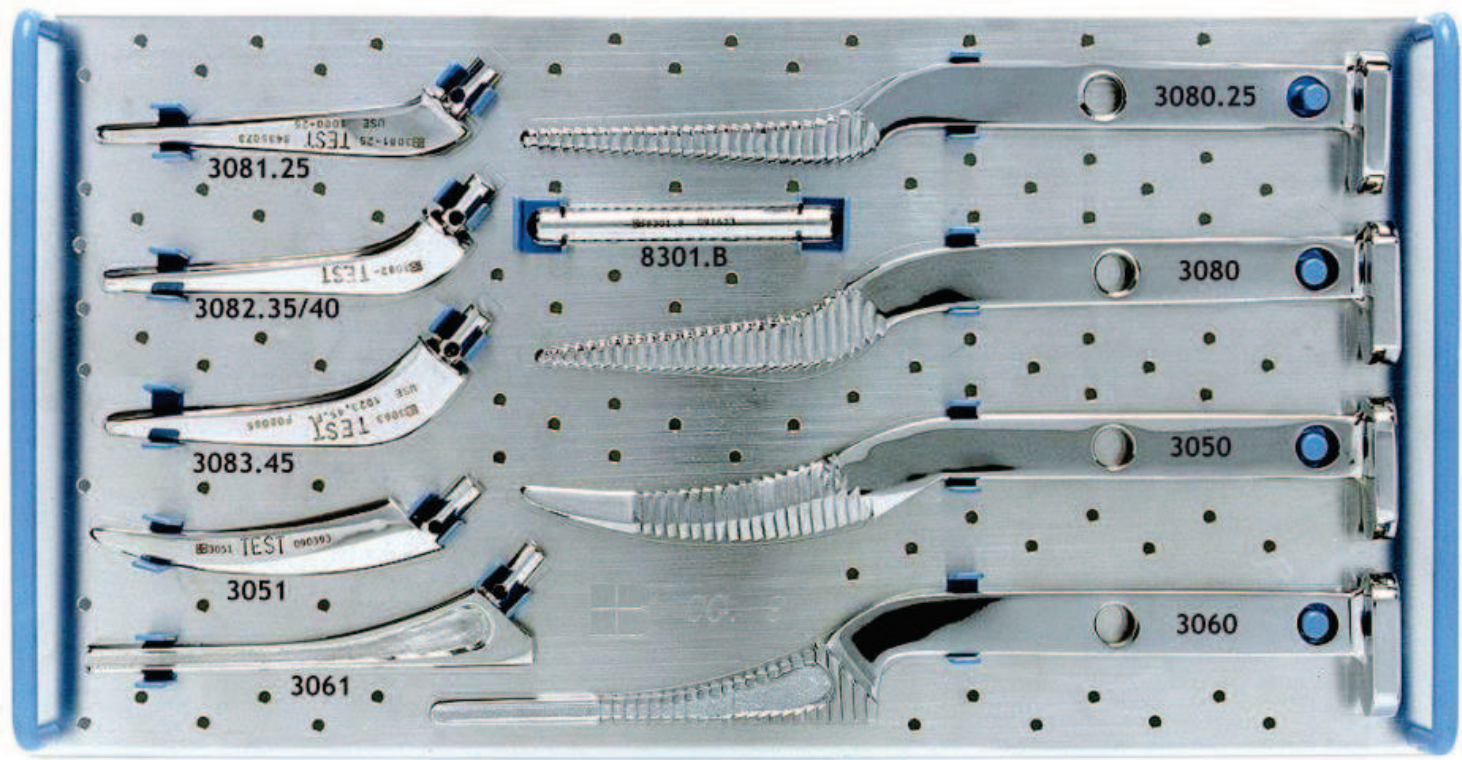

\begin{tabular}{|l|l|l|}
\hline Código & Quantidade & Descrição \\
\hline 3050 & 1 & Raspador de prótese de Thompson \\
\hline 3051 & 1 & Teste de prótese de Thompson \\
\hline 3060 & 1 & Raspador da prótese Moore \\
\hline
\end{tabular}




\begin{tabular}{|l|l|l|}
\hline 3061 & 1 & Teste de Prótese de Moore e New M. \\
\hline 3080 & 1 & Raspador Charnley normal \\
\hline 3080.25 & 1 & Raspador Charnley -Displasia \\
\hline 3081.25 & 1 & Teste da prótese Charnley \\
\hline $3082.35 / 40$ & 1 & Teste da prótese Charnley normal \\
\hline 3083.45 & 1 & Teste da prótese Charnley normal \\
\hline $8301 . B$ & 1 & Pino para extração do raspador \\
\hline
\end{tabular}

[BAUMER, 2010] 
- Instrumental cirúrgico para prótese de Maxxi Revisão

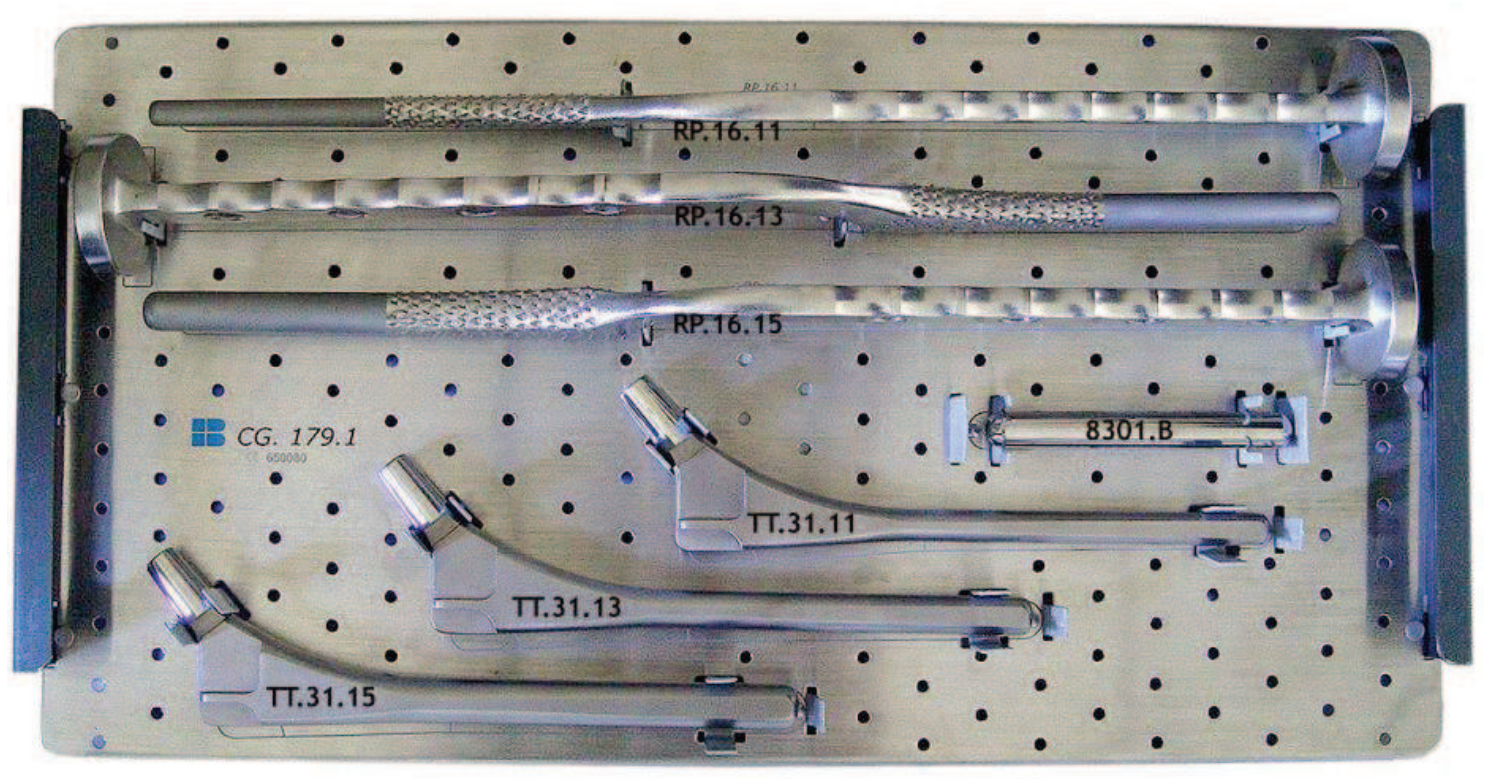

\begin{tabular}{|c|c|c|}
\hline Código & Quantidade & Descrição \\
\hline RP.16.11 & 1 & Raspador para prótese Maxxi - 11 mm \\
\hline RP.16.13 & 1 & Raspador para prótese Maxxi $-13 \mathrm{~mm}$ \\
\hline RP.16.15 & 1 & Raspador para prótese Maxxi $-15 \mathrm{~mm}$ \\
\hline TT.31.11 & 1 & Teste para prótese Maxxi $-11 \mathrm{~mm}$ \\
\hline TT.31.13 & 1 & Teste para prótese Maxxi $-13 \mathrm{~mm}$ \\
\hline TT.31.15 & 1 & Teste para prótese Maxxi $-15 \mathrm{~mm}$ \\
\hline 8301.B & 1 & Pino para extração do raspador \\
\hline FG.21 & 1 & Fio Guia \\
\hline
\end{tabular}

[BAUMER, 2010] 


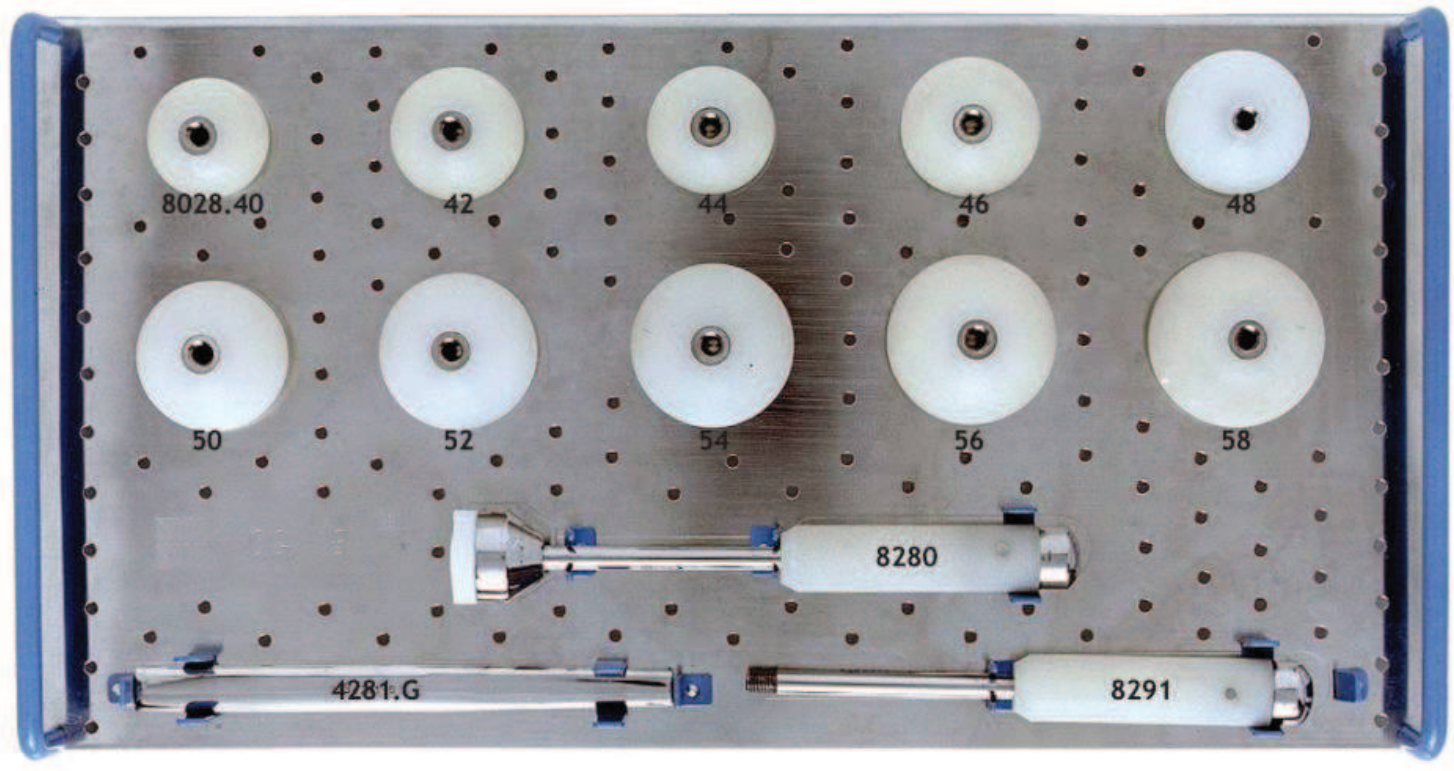

\begin{tabular}{|c|c|c|}
\hline Código & Quantidade & Descrição \\
\hline $4281 . G$ & 1 & Extrator de cabeça \\
\hline 8028. Ref. & 1 & Teste de acetábulo Bipolar $\varnothing$ 40-58 mm \\
\hline 8280 & 1 & Impactor de cabeça \\
\hline 8291 & 1 & Cabo padrão \\
\hline
\end{tabular}

